$$
\text { UNIVERSIDADE DE SÃO PAULO }
$$

FACULDADE DE FILOSOFIA, LETRAS E CIÊNCIAS HuMANAS

$$
\text { DiAnA MENDES MACHAdO DA SILVA }
$$

\title{
A Associação Atlética Anhanguera e o futebol de várzea na cidade de São Paulo (1928-1950)
}




\section{A Associação Atlética Anhanguera e o futebol de} várzea na cidade de São Paulo (1928-1950)

Dissertação apresentada à Faculdade de Filosofia Letras e Ciências Humanas da Universidade de São Paulo para obtenção do título de Mestre em História.

Área de concentração: História Social

Orientador: Prof. Dr. José Geraldo Vinci de Moraes

Versão Corrigida

(versão original disponível na Faculdade de Filosofia, Letras e Ciências Humanas)

São Paulo

2013

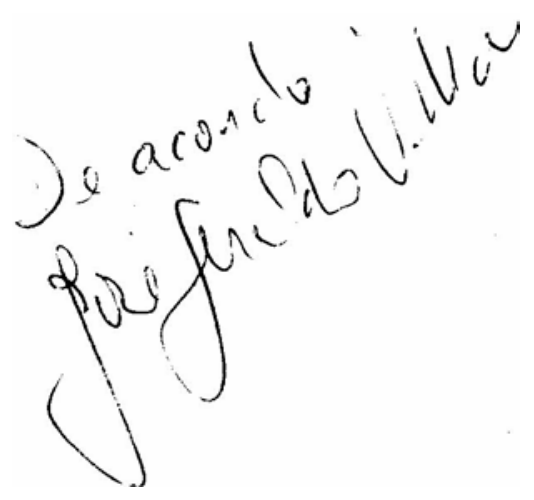




\title{
DiAna MENDES MACHAdO DA SiLVA
}

\section{A Associação Atlética Anhanguera e o futebol de várzea na cidade de São Paulo (1928-1950)}

\author{
Dissertação apresentada à Faculdade de Filosofia Letras e \\ Ciências Humanas da Universidade de São Paulo para \\ obtenção do título de Mestre em História. \\ Área de concentração: História Social \\ Orientador: Prof. Dr. José Geraldo Vinci de Moraes
}

Versão Corrigida

(versão original disponível na Faculdade de Filosofia, Letras e Ciências Humanas)

São Paulo

2013 
Nome: SILVA, Diana Mendes Machado da

Título: A Associação Atlética Anhanguera e o futebol de várzea na cidade de São Paulo (1928-1950)

Dissertação apresentada à Faculdade de Filosofia Letras e Ciências Humanas da Universidade de São Paulo para obtenção do título de Mestre em História.

Área de concentração: História Social

Orientador: Prof. Dr. José Geraldo Vinci de Moraes

Aprovado em:

Banca Examinadora

Prof. Dr.

Instituição:

Julgamento:

Assinatura:

Prof. Dr. Instituição:

Julgamento: Assinatura:

Prof. Dr. Instituição:

Julgamento: Assinatura: 


\section{AgRADECIMENTOS}

À Universidade de São Paulo, instituição que ainda cumpre um papel público de formação intelectual e profissional, cujos desdobramentos reconheço em minha trajetória.

Ao meu orientador, Professor José Geraldo Vinci de Moraes, pela generosidade com que acompanhou este trabalho, pelos comentários precisos e por me apresentar os encantos da cultura popular urbana.

Aos Professores Flavio de Campos e Luiz Henrique de Toledo, pelas contribuições oferecidas em minha banca de qualificação.

Ao amigo e parceiro de trabalho Arthur Tirone. Sem seu auxílio, esta pesquisa não seria possível. Sou grata também a Ângelo Tirone, por possibilitar o acesso ao acervo do clube por ele organizado, e a Júlio Velloso, pela gentileza em mediar meu contato com a Associação Atlética Anhanguera.

Aos veteranos da Associação Atlética Anhanguera - William Sandonato, Cirilo Magalhães, Walter Dias, Salathiel da Silva, José Bertollozzi e Clodoaldo Costa -, pelo prazer de suas companhias durante a realização desta pesquisa e pelas entrevistas concedidas. Agradeço também ao Sr. Pedro Cardoso as ricas histórias sobre sua família.

À Professora Idelette Muzart, a quem devo a formalização de meu intercâmbio na Université Paris $X$ durante o segundo semestre de 2011. A ela também sou grata pelas leituras de parte da dissertação e pelas sugestões de encaminhamento para a pesquisa. Agradeço ao Professor Jean-Pierre Blay a gentileza em me acolher no laboratório Sport et Culture da mesma universidade e em me oferecer sugestões de leitura.

Ao Professor Roger Chartier, que gentilmente leu e comentou parte deste trabalho, agradeço a possibilidade de participar do seminário Brasil Plural por ele organizado em parceria com estudantes brasileiros no Collège de France.

À Professora Mônica Schpun, pelas sugestões de encaminhamento da pesquisa e pelo convite para participar do grupo Migrations et espaces urbains no Centre de Recherches sur le Brésil Contemporain da École des Hautes Études en Sciences Sociales, entre fevereiro e junho de 2012. 
À Professora Odette Seabra, pela gentileza da entrevista concedida e por seu inspirador trabalho de livre-docência. Ao Professor Paulo Fontes, pelas preciosas questões e sugestões de leitura.

Ao Professor Ulpiano Toledo Bezerra de Meneses, pelo apreço à docência e ao conhecimento histórico traduzido em belíssimas aulas, algumas das quais tive o prazer de acompanhar.

Aos amigos leitores das variadas fases e faces deste trabalho: Clayton Peron, Dirceu Franco, Helena Weffort, Jorge Francisco, Ricardo Besen e Virginia Bessa. Agradeço especialmente ao Jorge a ajuda no trabalho com as plantas da cidade de São Paulo.

Aos amigos e colegas do Grupo Interdisciplinar de Estudos do Futebol - Enrico Spaggiari, Giovanna Capucim, João Streapco, Melina Nóbrega, Max Rocha, Marco Lourenço e Paulo Favero -, por nossas leituras, discussões e conquistas coletivas, das quais este trabalho é parte. Agradeço especialmente a parceria de Sérgio Setanni Giglio, as leituras cuidadosas e sugestões bibliográficas de Marcel Diogo Tonini, Marco Antunes, Paulo Nascimento e Vitor Canale.

Agradeço a Elizabety de Oliveira, Giulia Manera e Alexandre Antunes os auxílios a esta pesquisa.

Agradeço as leituras e correções de Elisa Vieira e Helena Meidani.

Agradeço também a Celso Unzelte e Danilo Cajazeira suas sugestões de leitura.

A Lia Paes de Barros, pela escuta atenta e amorosa.

Aos alunos do $3^{\circ}$ ano B da Escola Municipal CEU Butantã, de quem precisei me afastar em 2009 para a realização desta pesquisa. A Esmeralda Zago, Sabrina Teixeira, Edina Viana e Jussara, pelo que sonhamos e realizamos em prol de uma escola pública melhor e para todos.

Aos amigos do Projeto Direitos Humanos nas Escolas, pelas convicções compartilhadas e pela rica convivência intelectual: Adriana Sesti, Ana Carolina Filizolla, Camila Caffaro, Claudio Neto, Cosme Marins, Francisco Dias, Julia Andrade, Juliana Montoia, Luciana Gattamorta, Luciano Carvalho, Sandra Bittar, Teca Barbieri e Wellington Tibério.

Aos amigos do curso de graduação, presença constante e inspiradora: Alexandre Muscalu, Ana Karicia Dourado, André Machado, Claudinei Vieira, Claudio Ribeiro, 
Francisco Bezerra, Fransueldes de Abreu, Ivana Pansera, Fernanda Sposito, Lucas Kodama, Maria Ângela Raus e Surya Pombo.

Às amigas de longa jornada: Vera Lúcia de Assis, Adriana Cristina Dias, Bianca Bertini, Lis Bassi, Luciana Sá Teles e Virginia Bessa.

A Ines Schaller e Luciana Cardoso, que nos deixaram precocemente. Às sabiás da Rua Gaicá e aos seus filhotes do mês de setembro.

Aos meus pais Brás e Helena, à minha irmã Carolina e ao meu sobrinho Cauê, pela presença amorosa e pelo que ainda aprendemos juntos. À minha mãe, uma vez mais, por toda a ajuda que me ofereceu nesse período.

À Moana, presente da vida.

Ao Zé, com todo o meu amor. 
Pelo menos tão importante como a circunstância do que um povo joga, é certamente a de como esse jogo é praticado, em que formas se manifesta e se organiza e a que necessidades e tensões profundas ele propicia uma descarga.

Anatol Rosenfeld

Voltar a atenção para as condições e os processos que, muito concretamente, sustentam as operações de produção de sentido [...] é reconhecer, contra a antiga história intelectual, que nem as inteligências nem as idéias são desencarnadas e, contra os pensamentos do universal, que as categorias dadas como invariantes, sejam elas filosóficas ou fenomenológicas, devem ser construídas na descontinuidade das trajetórias históricas.

Roger Chartier 


\section{RESUMO}

SILVA, Diana Mendes Machado da. A Associação Atlética Anhanguera e o futebol de várzea na cidade de São Paulo (1928-1950). 2013. 203 f. Dissertação (Mestrado) Faculdade de Filosofia, Letras e Ciências Humanas, Universidade de São Paulo, São Paulo, 2013.

Esta pesquisa apresenta a trajetória de um clube de futebol de várzea, a Associação Atlética Anhanguera, entre o ano de sua fundação (1928) e o final da década de 1930, período de grandes transformações no futebol e na cidade de São Paulo. A investigação recorreu a fontes de imprensa e a documentos internos ao Anhanguera, sobretudo atas e entrevistas com associados veteranos para analisar a forma pela qual a associação de ítalo-brasileiros, situada à margem da cidade e do universo oficial do futebol, apropriouse da novidade que representava esse esporte. Um rico repertório de práticas culturais, como a intensa e criativa vida associativa do bairro, figurou como a base para essa apropriação. Esse mesmo repertório acabou por circular para além dos limites espaciais e simbólicos que a cidade impunha aos varzeanos. O tratamento dado ao futebol de várzea pelo periódico A Gazeta Esportiva, vinculando-o, aos poucos, a uma nova imagem de amadorismo, é um exemplo da ampliação desses limites.

Palavras-chave: Futebol de várzea; Barra Funda; Imigração italiana; Amadorismo; Associativismo. 


\section{Abstract}

SILVA, Diana Mendes Machado da. The Anhanguera Athletic Association and floodplain soccer in São Paulo city (1928-1950). 2013. 203 f. Dissertação (Mestrado) - Faculdade de Filosofia, Letras e Ciências Humanas, Universidade de São Paulo, 2013.

This research features the trajectory of Anhanguera Athletic Association, a floodplain (várzea) soccer club, starting from its founding year (1928) and going up to the end of 1930s, a period of intense changes in soccer practices as well as in urban life in São Paulo. Its establishment and organization, in a suburban district of São Paulo, as an amateur soccer association formed mostly by Italian-Brazilians, are described and analyzed having as resources the internal documents of Anhanguera Association - especially the records of meetings and senior associates' testimonies -, news from the press and data concerning immigration and the city process of urbanization. The practice of soccer was rooted in an intense and creative associative form of living, linked to other common leisure activities. The research also shows how the relationship between the club and the press led to a new image of amateur soccer practice, expanding the limits of its cultural experience in the city.

Keywords: Floodplain (várzea) soccer; Barra Funda; Italian immigration; Amateurism; Associativism. 


\section{LISTA DE ILUSTRAÇÕES}

Figura 1 - Rios Tietê e Pinheiros antes da retificação, em 1943

Figura 2 - Rio Tietê na cidade de São Paulo, ainda cheio de meandros no início do século XX........ 23

Figura 3 - Reprodução de fotografia da sede social à Rua Anhanguera, $n^{0} 250$............................... 34

Figura 4 - Reprodução da carteira de trabalho de Oswaldo Tirone, p. 2, 1918 .................................... 39

Figura 5 - Oswaldo Tirone com o veículo da empresa, anos 1950 _.................................................... 39

Figura 6 - Antônio Satriano em festa de família realizada na associação esportiva, na década

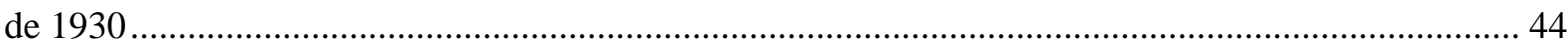

Figura 7 - Reprodução de ata da Associação Atlética Anhanguera........................................................ 49

Figura 8 - Oswaldo Tirone com amigos em um dos bares da Rua Anhanguera na década de 1940 ... 57

Figura 9 - Meninos jogam futebol em um dos campos do Anhanguera, anos 1930........................... 61

Figura 10 - Reprodução de ata da Associação Atlética Anhanguera, 19 nov. 1928............................. 70

Figura 11 - Reprodução das fotografias de carteirinhas de associados, s.d........................................ 74

Figura 12 - Time principal do Anhanguera, 1933; partida contra Clube Garibaldi............................ 75

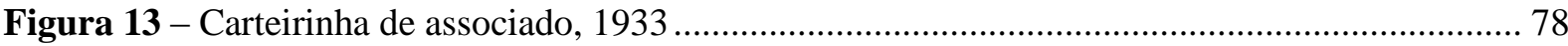

Figura 14 - Membros da Associação Atlética Anhanguera reunidos após festival, final dos

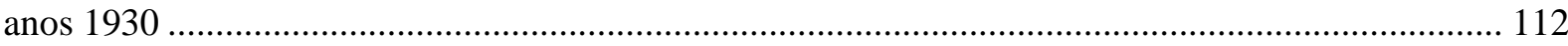

Figura 15 - Emblema da Associação Atlética Anhanguera, s.d. ....................................................... 118

Figura 16 - Estreia de camisas da Associação Atlética Anhanguera, anos 1930................................ 120

Figura 17 - Estreia de camisas da Associação Atlética Anhanguera, 1937 ....................................... 121

Figura 18 - Oswaldo Tirone vestido com o uniforme da Associação Atlética Anhanguera,

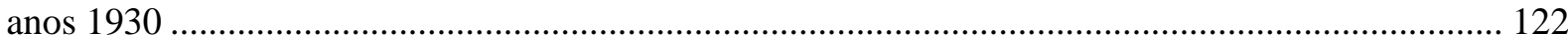

Figura 19 - Antenor Dias e sócio-jogadores dos times juvenis vestidos com uniformes da

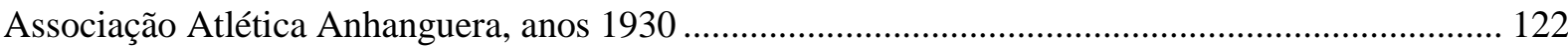

Figura 20 - Reprodução de fotografia e legenda de A Gazeta Esportiva, 6 jan. 1930........................ 142

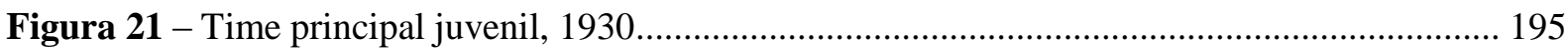

Figura 22 - Germano Bindo, Bartholomeu Maggi e João Faveta, 1932 …...................................... 195

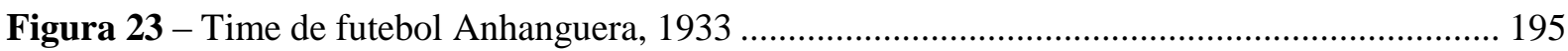

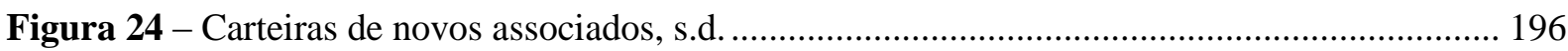

Figura 25 - Painel com o time principal da Associação Atlética Anhanguera, 1938 ........................ 196

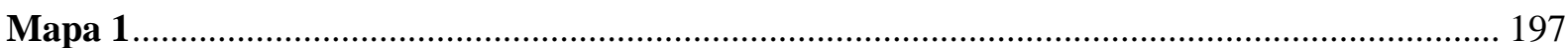

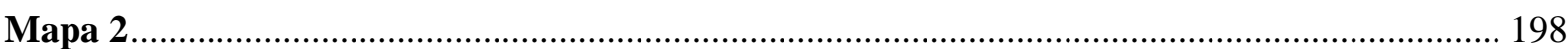




\section{SUMÁRIO}

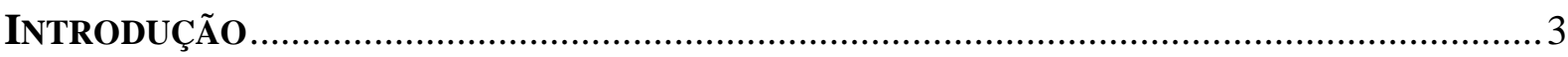

1. Nas várzeas e nos subúrbios: o surgimento da Associação Atlética Anhanguera......... 11

1.1. Desenraizar-se e enraizar-se: a instalação de imigrantes peninsulares na Barra Funda 11

1.2. A Barra Funda e a várzea dos ítalo-brasileiros ........................................................... 16

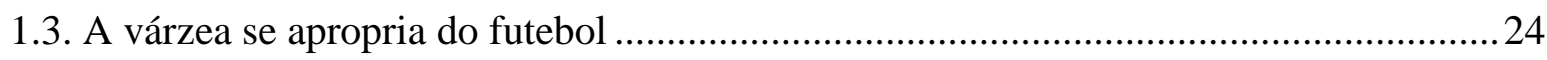

1.4. O clube Anhanguera: uma experiência associativa ................................................. 29

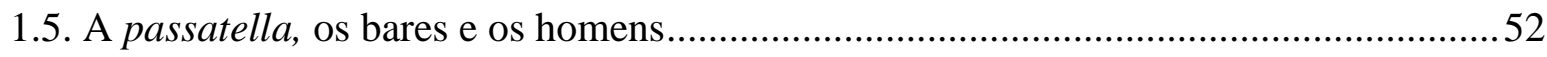

2. O futebol no Anhanguera: entre ajustes e conflitos de interesses.................................. 59

2.1. Circulação e estabilidade: os primeiros campos de futebol do Anhanguera .................59

2.2. Associação: adoção e demissão de novos associados ...............................................69

2.3. Saverio, Barthô e a dinâmica do futebol .......................................................................... 79

2.4. A Associação Atlética Anhanguera e o Clube Atlético Paulistano: semelhanças entre o futebol de várzea e o de elite?.................................................................... 95

3. O Anhanguera, a várzea dos ítalo-brasileiros e A Gazeta Esportiva …........................... 105

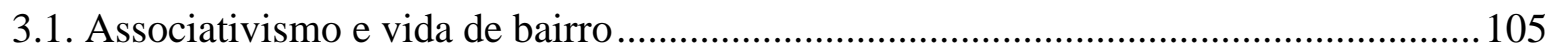

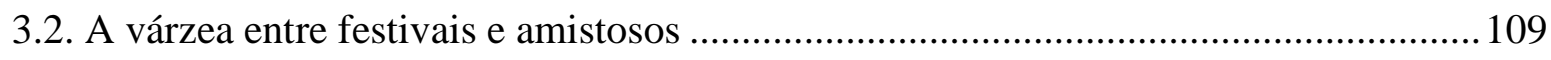

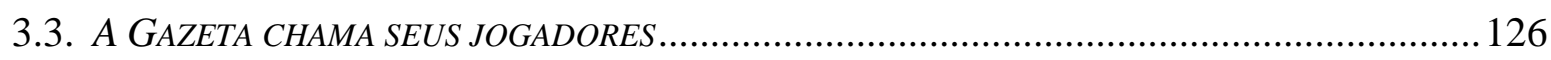

3.4. A Gazeta Esportiva e a Associação Atlética Anhanguera ......................................... 135

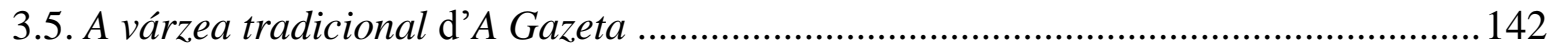

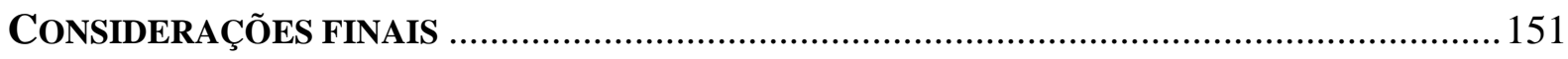

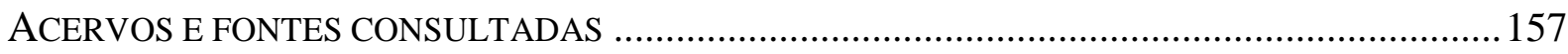

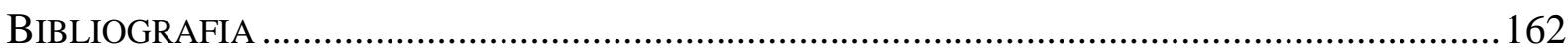

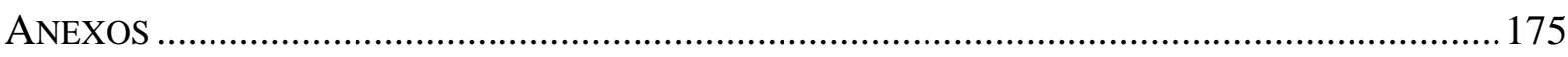




\title{
INTRODUÇÃO
}

\begin{abstract}
Ao invés de permanecer no terreno de um discurso que mantém o seu privilégio invertendo o seu conteúdo (que fala de catástrofe e não mais de progresso), pode-se enveredar por outro caminho: analisar as práticas microbianas, singulares e plurais, que um sistema urbanístico deveria administrar ou suprimir e que sobrevivem a seu perecimento; seguir o pulular desses procedimentos que, muito longe de ser controlados ou eliminados pela administração panóptica, se reforçaram em uma proliferação ilegitimada, desenvolvidos e insinuados nas redes de vigilância, combinados segundo táticas ilegíveis, mas estáveis a tal ponto que constituem relações cotidianas e criatividades sub-reptícias que se ocultam somente graças aos dispositivos e aos discursos, hoje atravancados, da organização observadora. Michel de Certeau
\end{abstract}

Em 1928, mais um clube esportivo é fundado por ítalo-brasileiros no bairro da Barra Funda, em São Paulo. Tal como acontecia a dezenas de associações esportivas da região, a recém-criada Associação Atlética Anhanguera passava também a usufruir da várzea do Rio Tietê para a prática do futebol. Promovendo bailes, festivais esportivos e uma série de modalidades lúdicas entendidas como divertimentos indissociáveis do cotidiano da várzea, o clube rapidamente angariou associados e se integrou ao rico cotidiano recreativo do bairro. Além disso, manteve-se na região com sede social própria, campos de futebol e um estável conjunto de sócios, a despeito das modificações urbanas ali iniciadas nos anos 1930 que levaram ao desaparecimento dos espaços livres do bairro e, com eles, de inúmeras instituições dedicadas ao esporte e ao lazer. E mesmo sem nunca ter ingressado nas ligas do futebol oficial da cidade, o clube era frequentemente reportado por A Gazeta Esportiva desde 1929, ano seguinte à sua fundação.

Esses são alguns dos elementos que justificam a escolha da trajetória da Associação Atlética Anhanguera como o eixo fundamental da presente pesquisa. Acompanhar seus primeiros anos de atividade, entre o ano de sua fundação (1928) e o final da década de $1930^{1}$,

\footnotetext{
${ }^{1}$ Optou-se por restringir o período dessa pesquisa, anteriormente delimitado entre os anos 1928 e 1958, para o período 1928 e 1939. Entretanto, não houve possibilidade de realizar essa alteração junto aos órgãos
} 
permitiu visualizar como uma comunidade imigrante situada no subúrbio da cidade - à margem dos benefícios oferecidos pelo poder público e à margem das ligas oficiais do esporte - apropriou-se do futebol. Longe de ser exclusividade do Anhanguera ou da comunidade ítalo-brasileira instalada na várzea, essa questão é também reveladora das formas de apropriação e de produção do espaço urbano.

É em face da capacidade de produzir e possibilitar a circulação de práticas, sentidos e valores que o futebol figura como outro eixo central deste trabalho. Ele aqui representa um índice de práticas socioculturais urbanas; uma linguagem comum ao permitir o diálogo entre grupos distintos e, por vezes, também desiguais ${ }^{2}$ e um discurso a partir do qual esses grupos se autorrepresentaram. ${ }^{3}$ Assim, além de ser parte fundamental do objeto de estudo, o esporte figura como uma privilegiada plataforma de observação das transformações sociais e culturais pelas quais passava a cidade naqueles anos de 1930 .

Esse objeto e essa perspectiva de trabalho tomaram forma a partir do contato com a vasta documentação recolhida e preservada por associados do clube. Compostos por atas semanais no período entre 1928 e 1934, cartões de sócios e fotografias, além de recortes de periódicos, taças e medalhas e um conjunto de entrevistas, tais documentos foram preciosos por se tratarem de vestígios deixados pelos próprios agentes. Não representam, pois, a atuação de órgãos oficiais responsáveis, por exemplo, pelo intenso controle dos campos e clubes de futebol varzeanos no período.

responsáveis pela publicação da dissertação. Por essa razão, a dissertação é apresentada tendo como limite final o ano de 1958, muito embora o trabalho concretamente realizado tenha utilizado como baliza final o ano de 1939.

${ }^{2}$ Considerando-se não apenas o perfil socioeconômico desses grupos, mas também seu estatuto político na São Paulo dos anos 1930. A começar pelo fato de que, mesmo possuindo taxas menores de analfabetismo em relação ao restante do país, a cidade se aproximava da média nacional da época, isto é, cerca de $70 \%$ de sua população era ainda analfabeta.

${ }^{3}$ Essas dimensões são bastante exploradas em ensaios e pesquisas recentes. Cf., por exemplo, FLORENZANO, José Paulo. A democracia corinthiana: práticas de liberdade no futebol brasileiro. São Paulo: Educ/Fapesp, 2009; WISNIK, José Miguel. Veneno remédio: o futebol e o Brasil. São Paulo: Companhia das Letras, 2008; FRANCO JÚNIOR, Hilário. A dança dos deuses: futebol, sociedade, cultura. São Paulo: Companhia das Letras, 2007. 
Tal singularidade permitiu adentrar num universo pouco explorado nas pesquisas acadêmicas sobre futebol: o cotidiano dos clubes populares. Ao acompanhar nas atas os conflitos e as negociações cotidianas foi possível apreender quem eram os varzeanos ítalobrasileiros responsáveis pelo Anhanguera e quais foram seus itinerários para estabelecer e manter seu clube na várzea.

Nesse processo, destaca-se a situação de desenraizamento e enraizamento vivida pelos imigrantes da península itálica na cidade de São Paulo. Com base em suas artes cotidianas, para tomar de empréstimo uma noção de Michel de Certeau, a comunidade manteve tradições trazidas da península ao mesmo tempo em que incorporou outras tantas já enraizadas na cidade de adoção. As artes relacionadas ao trabalhar, ao habitar e às práticas lúdicas como o futebol são algumas especificidades que trouxeram contornos muito específicos aos modos de vida do lugar.

Por sua vez, as fontes de imprensa foram fundamentais não só para cotejar algumas das informações encontradas nos documentos internos ao clube, como para compreender como se davam as relações estabelecidas entre os incipientes suplementos esportivos da imprensa paulista e seu público consumidor, em evidente alteração na passagem dos anos 1920 para a década seguinte. Não se pode esquecer que a cidade de São Paulo vivia a construção de seu discurso identitário calcado na valorização do trabalho e dos imigrantes, sobretudo europeus.

Complexas e imbricadas em diferentes temporalidades e espacialidades, estas questões foram mobilizadas para compreender como os anhanguerenses vivenciaram o futebol. Tratase, pois, de uma observação particularizada e a periodização escolhida ilustra essa preocupação. Com início em 1928, ano de fundação do Anhanguera, acompanhou-se a forma pela qual o clube e seus associados se estabeleceram na várzea da Barra Funda, quais as atividades por eles desenvolvidas e como um rico associativismo de bairro foi constitutivo 
dessas experiências - algo não generalizável ao que viviam, por exemplo, os associados dos clubes de elite vinculados ao universo oficial do esporte. Embora mantivessem pontos de contato com a várzea na forma como reagiram ao processo de profissionalização do futebol, clubes como o Paulistano, organizados sob o modelo do football association, não lidavam com os mesmos dilemas, nem encontravam as mesmas dificuldades para vivenciar o esporte na cidade.

O limite final da periodização foi estabelecido em diálogo não apenas com as transformações que o clube Anhanguera viveu no início dos anos 1940, mas também com aquelas que marcaram os bairros da Barra Funda e do Bom Retiro, sobretudo as que se referem às relações entre as associações políticas, recreativas e esportivas a partir da intensa industrialização da região naquele momento. Além disso, em graus e modos variados, a intensificação do processo de profissionalização do futebol, o advento do Estado Novo, a eclosão da Segunda Guerra Mundial e a Copa do Mundo de 1938 também contribuíram para modificar tais relações, sobretudo ao se considerar a centralização das identidades coletivas sob a ideia da nacionalidade. O recorte temporal efetuado com base em tal particularização possibilitou, pois, um maior controle sobre as informações construídas por meio das fontes primárias.

As entrevistas com os veteranos do clube representaram outra rica fonte de informação. Embora muitas não tenham sido incorporadas por fugirem à periodização em pauta, elas não deixaram de apontar caminhos em relação aos aspectos que mereceriam maior atenção na pesquisa. Uma consideração sobre o trabalho com a memória tem por base uma afirmação de Ecléa Bosi acerca da "veracidade do narrador". Para a autora, tal questão nunca a preocupou em suas pesquisas, pois "com certeza seus erros e lapsos são menos graves em suas consequências que as omissões da história oficial. Nosso interesse está 'no que foi 
lembrado', no que foi escolhido para perpetuar-se na história de sua vida". Nesse sentido, a pesquisa procurou aproximar-se do que foi escolhido para ser lembrado pelos veteranos do Anhanguera. Mais do que a veracidade dos dados aos quais eles se referiram, interessava entrever que práticas e sentidos sustentavam suas lembranças.

Questões de cunho teórico especificamente relacionadas ao universo do futebol também emergiram, em meio a uma série de impasses. Por ser o futebol de várzea um campo de fontes escassas e renitentes, ${ }^{5}$ raros também são os trabalhos que adentram sua especificidade. ${ }^{6}$ Isso parece explicar a tendência em focar a experiência varzeana apenas a partir de seus vínculos com o universo oficial, amador ou profissional, do esporte. Daí o uso difuso e generalizado de noções como popularização e profissionalização para tratar de clubes e jogadores populares no início do século XX. Embora ambas sejam importantes categorias operativas, elas pouco nos ajudam a compreender a atuação de clubes que não se oficializaram, não se profissionalizaram, mas também não desapareceram, caso do

\footnotetext{
${ }^{4}$ BOSI, Ecléa. Memória e sociedade: lembrança de velhos. São Paulo: Companhia das Letras, 2007, p. 37.

${ }^{5}$ E como os estudos sobre história do futebol não o configuram como um campo ou uma linha de pesquisa na historiografia, os trabalhos ligados à cultura popular - ao seu cotidiano e à sua sociabilidade - foram centrais nesta pesquisa. Aqui destacamos os seguintes: FAUSTO, Boris. $O$ crime do restaurante chinês: carnaval, futebol e justiça na São Paulo dos anos 30. São Paulo: Companhia das Letras, 2009; GAMA, Lúcia. Nos bares da vida: produção cultural e sociabilidade em São Paulo (1940-1950). São Paulo: Ed. Senac, 1998; MORAES, José Geraldo Vinci de. Metrópole em sinfonia: história, cultura e música popular na São Paulo dos anos 30. São Paulo: Estação Liberdade, 2000; SCHPUN, Mônica Raisa. O cinema mudo em São Paulo: experiências de italianos e italianas, práticas urbanas e códigos sexuados. ArtCultura, Uberlândia, v. 9, n. 14, p. 71-81, jan.-jun. 2007; SIQUEIRA, Uassyr de. Entre maxixes, peladas e palavras de ordem: associações dos trabalhadores paulistanos durante a Primeira República. Revista Esboços, Florianópolis, v. 12, n. 14, p. 75-86, 2005.

${ }^{6}$ As exceções são: HIRATA, Daniel Veloso. Futebol de várzea: um estudo sobre práticas urbanas e seus territórios. Dissertação (Mestrado em Sociologia) - Universidade de São Paulo, São Paulo, 2005; JESUS, Gilmar Mascarenhas de. Construindo a cidade moderna: a introdução dos esportes na vida urbana do Rio de Janeiro. Revista Estudos Históricos, São Paulo, v. 13, n. 23, 1999; Várzeas, operários e futebol: uma outra geografia. Geographia: Revista do Programa de Pós-Graduação em Geografia da UFF, Niterói, v. 4, n. 8, p. 84-92, 2002; e SEABRA, Odette Carvalho de Lima. Urbanização e fragmentação: cotidiano e vida de bairro na metamorfose da cidade em metrópole, a partir das transformações do Bairro do Limão. Tese (Livre-Docência em Geografia) - Faculdade de Filosofia, Letras e Ciências Humanas, Universidade de São Paulo, São Paulo, 2003. Além disso, podem-se citar alguns artigos reunidos na coletânea Futebol: espetáculo do século, organizada por Márcia Regina da Costa et al. (São Paulo: Musa Editora, 1999); e os trabalhos que dedicam capítulos ao tema: ANTUNES, Fátima M. R. Ferreira. Futebol de fábrica em São Paulo. Dissertação (Mestrado) - Faculdade de Filosofia, Letras e Ciências Humanas, Universidade de São Paulo, São Paulo, 1992; e NEGREIROS, Plínio José L. de Campos. Resistência e rendição: a gênese do Sport Club Corinthians Paulista e o futebol oficial em São Paulo, 1910-1916. Dissertação (Mestrado em História) - Faculdade de História, Pontifícia Universidade Católica, São Paulo, 1992.
} 
Anhanguera e de tantos outros de sua geração. Nesse sentido, a pesquisa procura também oferecer elementos para a compreensão do que corria paralelamente ao futebol das ligas oficiais.

Não se trata, no entanto, de negar aqui o diálogo, a permeabilidade ou a circularidade cultural entre os universos oficial e extraoficial do futebol praticado em São Paulo. Como já alertava Matthew Shirts, em 1982, ao escrever sobre a história dos primeiros anos do esporte em São Paulo ${ }^{7}$ : mais importante do que reafirmar as controvérsias sobre onde, quando e como o futebol começa a ser praticado e difundido, é notar que a problemática de fundo está, desde muito cedo, inscrita na disputa por seu controle ideológico. Assim, em lugar de procurar identificar os responsáveis pela introdução ou popularização do futebol na cidade, optou-se por perceber, num outro nível, as trocas realizadas entre praticantes do esporte oriundos da elite ou de segmentos populares. Para tanto, um conceito menos estrito de cultura foi mobilizado. Compreendida na ampla acepção de interação, a cultura é o âmbito em que se declaram:

valores e propõem-se sentidos que podem entrar em conflito com outros valores e sentidos. Os conflitos, portanto, devem ser considerados não apenas como ingrediente normal da cultura, mas como instância geradora, força motriz. Como consequência, pretender que a cultura tenha funções anestésicas, de harmonização e integração social, já é uma forma cultural de agir (segundo interesses hegemônicos), mas desfigura o fenômeno se pretender eliminar de seu horizonte especificamente o conflito, a desarmonia, a segmentação. ${ }^{8}$

Assim, a perspectiva desta pesquisa não nega nem a importância da circularidade cultural para compreender como São Paulo construiu seu futebol, nem a relevância dos conflitos em tal construção ao observar esse complexo processo a partir da trajetória de um clube de futebol popular.

\footnotetext{
${ }^{7}$ SHIRTS, Matthew G. Literatura futebolística: uma periodização. In: MEIHY, José Carlos S. B.; WITTER, José S. (Orgs.). Futebol e cultura: coletânea de estudos. São Paulo: Imprensa Oficial: Arquivo do Estado, 1982.

${ }^{8}$ MENESES, Ulpiano Toledo Bezerra de. Os usos culturais da cultura: contribuição para uma abordagem crítica das práticas e políticas culturais. Transcrição da conferência proferida no encerramento do Congresso Internacional de Geografia e Planejamento do Turismo, 1995.
} 
Tal perspectiva possibilitou, por exemplo, superar a noção amplamente difundida de que o futebol popular seria fruto do decalque ou do mimetismo das práticas de seus supostos introdutores na cidade. Embora o conjunto de regras oficiais - constantemente lembradas pelos órgãos responsáveis por organizar o futebol na cidade - tenha garantido uma base comum para a prática do jogo, sua apropriação não se deu de maneira homogênea. O esporte assumiu conotações diferentes entre imigrantes pobres e seus descendentes, bem como entre ex-escravos e caipiras.

Sobre esse aspecto, há que se ressaltar a relação peculiar construída entre a imprensa esportiva e o futebol praticado nas regiões de várzea, sobretudo nos arredores do Rio Tietê. Associado aos discursos acerca de regionalismos e da nacionalidade, ele torna-se central para a compreensão da perspectiva sob a qual a imprensa esportiva é aqui trabalhada. Fátima Ferreira Antunes lança luz sobre o papel desses discursos integradores ao analisar o poder irradiador das ideias de José Lins do Rêgo, Mário Filho e Nelson Rodrigues nos periódicos da capital brasileira, durante as primeiras décadas do século passado. ${ }^{9}$ Para ela, a ligação desses autores com os centros de poder - dos clubes esportivos, da própria imprensa, da confederação de desportos ou mesmo do governo fluminense e federal - explica a rápida difusão de suas ideias e fornece pistas sobre a assunção do discurso nacionalista que então se formava. Por meio do futebol e em diálogo com acadêmicos e políticos influentes, aqueles jornalistas, ${ }^{10}$ traduziram para a população o discurso sobre o ser nacional. Nota-se, pois, a permeabilidade entre Estado e sociedade - ou, ainda mais especificamente, entre Estado e imprensa - na produção do discurso nacional.

No caso de São Paulo, essa questão apresenta nuances regionais, principalmente a

\footnotetext{
${ }^{9}$ Discussão também desenvolvida em: SILVA, Marcelino Rodrigues da. Mil e uma noites de futebol: o Brasil moderno de Mário Filho. Belo Horizonte: Ed. UFMG, 2006; HOLLANDA, Bernardo B. Buarque de. $O$ descobrimento do futebol: modernismo, regionalismo e paixão esportiva em José Lins do Rego. Rio de Janeiro: Biblioteca Nacional, 2004.

${ }^{10}$ Foram leitores e colegas de intelectuais como Gilberto Freyre, como no caso de Mário Filho.
} 
partir do aparecimento d'A Gazeta Esportiva - que, tal como o Anhanguera, surge no ano de 1928. A opção por acompanhá-la se justifica também pelo posicionamento diferenciado que ela assumiu em relação aos dos jornais $O$ Estado de S. Paulo e Folha da Manhã, com os quais passou a concorrer oferecendo aos setores médios da sociedade paulistana um contraponto à tradicional perspectiva da elite agrária.

O primeiro capítulo é dedicado a acompanhar como os peninsulares e seus descendentes se estabeleceram na região varzeana da cidade e dela se apropriaram física e simbolicamente, muitas vezes em conflito com o poder público. Discorre-se, ainda, sobre o universo do trabalho e o uso do tempo livre em tal processo de integração à cidade, bem como sobre alguns elementos relacionados à criação do clube e ao estabelecimento de um cotidiano que agregava os associados em torno de diversas atividades. Um rico associativismo de bairro figurou como a base dessas experiências, o que se estendeu ao futebol.

Esses aspectos são então mobilizados no segundo capítulo a fim de compreender quais foram as bases de organização da vida esportiva do clube. Vale ressaltar que, embora o Anhanguera não integrasse as ligas que organizavam o futebol oficial, não deixava de com este se relacionar. O clube viveu, sobretudo entre os anos 1928 e 1931, de maneira semelhante ao aristocrático clube Paulistano, as tensões impostas pela competência esportiva, entre outras pautas e demandas da LAF e da APEA, o que também revela suas dificuldades em se manter paralelo àquele universo.

O terceiro capítulo, por sua vez, desloca-se das questões internas do clube e procura compreendê-lo em meio a outras instituições da Barra Funda e do Bom Retiro e às formas como estava organizada a vida recreativa e esportiva dos moradores desses bairros. Formas estas que se inscreviam no campo das disputas simbólicas por uma identidade social no espaço urbano. Por último, considera-se a entrada de A Gazeta Esportiva no incipiente mercado editorial esportivo e a relação por ela mantida com o universo varzeano. O periódico 
ofereceu um espaço até então inédito para os clubes de várzea, designando-os como os representantes de um futebol tradicional e moderno. O futebol de várzea, ali retratado fundamentalmente na figura dos ítalo-brasileiros - seus clubes, procedimentos e costumes -, passou a ser apresentado pelo periódico como uma nova forma de amadorismo a ser valorizada na medida em que representava o povo, categoria já bastante cara à imprensa e ao Estado Nacional naquele momento.

\section{Nas várzeas e nos subúrbios: o surgimento da Associação Atlética Anhanguera}

\subsection{Desenraizar-se e enraizar-se: a instalação de imigrantes peninsulares na Barra}

\section{Funda}

Quando fundaram a Associação Atlética Anhanguera, Saverio Russo, Bartholomeu Maggi, Ezzio Marchetti e outros jovens descendentes dos primeiros emigrantes da península itálica circulavam pelo bairro da Barra Funda havia algum tempo. Seus pais e avós chegaram à região entre 1870 e 1900 e, como centenas de imigrados, fixaram residência nas imediações da Hospedaria dos Imigrantes $^{11}$ e das recém-criadas ferrovias Sorocabana e São Paulo Railway (mapa 1). ${ }^{12}$ Esse foi o caso do pai de Saverio, que se instalou no Largo da Banana em $1876,{ }^{13}$ e da família Vignola, cujo patriarca, Consolato, chegara à região em 1896, com

\footnotetext{
${ }^{11}$ Responsável pela sistematização e pela racionalização dos serviços de alojamento para imigrantes, "a hospedaria foi inaugurada no Bom Retiro, na confluência da antiga Rua dos Imigrantes - atual José Paulino - e Rua Tenente Pena. Um novo prédio, com maior capacidade, foi construído a partir do grande afluxo de imigrantes na cidade que ficou conhecido como a hospedaria dos imigrantes do Brás" (PERELMUTTER, Daisy. Um Bom Retiro. São Paulo: SESC, 2011, p. 3).

${ }^{12}$ Primeiramente, a Ferrovia Sorocabana, criada em 1870 para ligar com mais agilidade o polo de produção ao de distribuição do café, instalou uma de suas estações na Barra Funda. Em 1892, foi a vez de a Ferrovia São Paulo Railway fazer o mesmo.

${ }^{13}$ Região onde hoje se encontra o Memorial da América Latina e o viaduto Pacaembu. A família lá permaneceu por décadas, até as novas gerações se mudarem para o Bom Retiro (segundo relatou Rodrigo Russo, neto de Saverio, em conversa informal ocorrida em maio de 2010).
} 
apenas três anos de idade. ${ }^{14}$ Já a família Tirone, cuja trajetória se confunde com a do clube Anhanguera, contando com três gerações a ele associados, ${ }^{15}$ estabeleceu-se na região da Rua Cruzeiro no mesmo período, por volta de 1895 , na figura do calabrês Nicola Tirone e de sua esposa.

Ao imigrar para a capital de São Paulo, essas famílias encontraram condições bastante diferentes das enfrentadas por aqueles que vinham atender à lavoura cafeeira no Oeste Paulista. Sua chegada possuía conteúdo extra de preocupações, pois, ao contrário dos agricultores, não contavam com subsídios para a viagem, garantias de trabalho e tampouco com a companhia da família. ${ }^{16}$ Principalmente para eles, a hospedaria cumpriu papel fundamental ao possibilitar a rede de contatos entre os imigrantes já estabelecidos e os recémchegados à cidade. Dessa rede derivou a preferência por habitar certos bairros da região central de São Paulo. A possibilidade de estar perto de familiares, amigos e conhecidos e de trabalhar a partir de contatos por eles fornecidos não parecia ser de pouca importância para quem nem mesmo conhecia a língua do novo país.

Acrescente-se que esses pioneiros chegaram a São Paulo como vênetos, campânios ou calabreses, ${ }^{17}$ falando dialetos regionais e não um idioma unificado territorialmente, como destaca a linguista Elisabetta Santoro: "Na Itália, no final do século XIX, a língua ainda não era o italiano para todo mundo. [...] as pessoas não sabiam falar italiano. [...] a unificação da

\footnotetext{
${ }^{14}$ Consolato Vignola era tio de Antônio e Miguel Vignola, que viriam a ser importantes diretores do Anhanguera e também os responsáveis pela cessão de terrenos e do prédio da primeira sede do clube. Consolato se tornou parte da família Satriano, também ligada ao clube, ao casar-se com Filomena Satriano, em 1912 (entrevista com o Sr. Pedro Cardoso, neto de Consolato Vignola, realizada em $1^{\circ}$ de agosto de 2012).

${ }^{15}$ Oswaldo Tirone foi registrado na associação em 1929; seu filho, Wladimir, no fim dos anos 1960. Hoje, os três filhos de Wladimir - Arthur, Ângelo e Bruno - são associados.

${ }^{16}$ Para Zuleika Maria Alvim, a imigração dos mais pobres, oriundos do sul da Itália, tem início nos anos 1890, justamente quando se inicia maior afluxo para a capital de São Paulo. No mesmo período, aumenta significativamente a imigração de peninsulares desacompanhados da família (O Brasil italiano (1880-1920). In: FAUSTO, Boris (Org.). Fazer a América. São Paulo: Edusp, 2000).

${ }^{17}$ Advindos de regiões das quais vieram a maior parte dos imigrantes italianos. Segundo dados do IBGE, entre 1876 e 1920, emigraram para o Brasil: 365.710 vênetos, 166.080 campânios e 113.115 calabreses (Cf. IBGE. Brasil: 500 anos de povoamento. Rio de Janeiro, 2000). Note-se ainda que a região do Vêneto localiza-se ao norte da Itália, enquanto a Campânia e a Calábria, pobres e rurais, encontram-se ao sul.
} 
Itália como país, como nação, era um fato recente". ${ }^{18}$ É fácil imaginar que, por essa razão, mesmo o diálogo mais simples entre conterrâneos se tornasse tarefa complexa. Considere-se ainda que, além da profusão de dialetos peninsulares, também se ouviam em São Paulo línguas como o castelhano, o árabe e, mais tarde, o japonês. ${ }^{19}$ Ao contrário do que se imagina, uma nova Babel não foi instaurada na cidade; a necessidade de comunicação acabou por rapidamente firmar o português como língua franca nos bairros que mais receberam esses imigrantes, caso da Barra Funda, do Bom Retiro e do Brás. Isso ocorreu de maneira bastante peculiar, a partir de arranjos linguísticos variados como os dialetos francos utilizados na cidade, caso do talian, que consistia em "uma mistura entre o dialeto vêneto e o português". 20

Esse processo de "mistura" esteve associado apenas ao português falado, pois, em geral, os peninsulares aqui chegavam sem o domínio do código formal da escrita. ${ }^{21} \mathrm{Na}$ Calábria, terceira região italiana a enviar emigrados para o Brasil, menos de $50 \%$ da população sabia ler e escrever em $1911 .^{22}$ A situação só se alteraria na península nos primeiros anos do século XX, a partir da adoção do italiano como língua oficial e do impulso estatal de alfabetização massiva da população, medidas que integravam o movimento de construção de uma identidade nacional italiana. Tal como a formação de seu Estado, a unificação linguística da Itália aconteceu tardiamente. Tal processo seria concluído apenas nos anos 1920, a partir da centralização totalitária do poder político experimentada com o

\footnotetext{
${ }^{18}$ Informação fornecida na palestra L'Italia e l'italiano in Brasile: tra immigrazione e attualità, realizada em 26 de janeiro de 2012 na Université Paris X. Evidentemente, Santoro se refere ao que se configuraria como língua italiana, ou seja, fundamentalmente o dialeto da região da Toscana.

19 Aos italianos, que representaram praticamente um terço dos imigrantes de São Paulo (cerca de 945 mil pessoas), seguiram-se respectivamente essas nacionalidades, considerando-se o período 1894-1933 (Cf. IBGE, op. cit.; HALL, Michael. Imigrantes na cidade de São Paulo. In: PORTA, Paula (Org.). História da cidade de São Paulo: a cidade na primeira metade do século XX, 1890-1954. São Paulo: Paz e Terra, 2004, v. 3, p. 124).

${ }^{20}$ Falado especialmente no Espírito Santo e em Santa Catarina. Há indícios de sua presença também em São Paulo (Informação fornecida pela Profa. Dra. Elisabetta Santoro na palestra L'Italia e l'italiano in Brasile: tra immigrazione e attualità, realizada em 26 de janeiro de 2012).

${ }^{21}$ Dado que parecia se repetir entre os nacionais, pois, à época, cerca de $80 \%$ da população era analfabeta (Cf. IBGE. Brasil..., cit.).

${ }^{22}$ BIONDI, Luigi. Entre associações étnicas e de classe: os processos de organização política e sindical dos trabalhadores italianos na cidade de São Paulo (1890-1920). Tese (Doutorado) - Instituto de Filosofia e Ciências Humanas, Universidade Estadual de Campinas, Campinas, 2002, p. XVIII.
} 
regime fascista. ${ }^{23}$

Assim, peninsulares alfabetizados e falantes de um idioma nacional só chegaram à Barra Funda anos depois, nas últimas levas de imigração para a cidade. ${ }^{24}$ É, pois, nesse sentido que se pode compreender as conhecidas variações que caracterizam o uso do português falado em São Paulo ${ }^{25}$ como marcas de um processo de incorporação de uma língua nova sem, no entanto, abandonar de todo os elementos que estruturavam a anterior. A falta de domínio da língua escrita, tanto entre os nacionais quanto entre os imigrantes, contribuiu para que os criativos recursos próprios à oralidade facilitassem a integração entre eles. ${ }^{26}$

Os ítalo-brasileiros, entre os quais estavam os fundadores da Associação Atlética Anhanguera, não conheceram as mesmas dificuldades enfrentadas por seus antecessores.

\footnotetext{
${ }^{23}$ Informação fornecida pela Profa. Dra. Elisabetta Santoro na palestra L'Italia e l'italiano in Brasile: tra immigrazione e attualità, realizada em 26 de janeiro de 2012. Cf. também: FAUSTO, Boris. Imigração: cortes e continuidades. In: NOVAIS, Fernando A. (Org.). História da vida privada no Brasil. v. 4. São Paulo: Cia das Letras, 1998.

${ }^{24}$ Já relacionadas às consequências do regime fascista no fim dos anos 1920 - exceção feita, uma vez mais, aos oriundos de famílias de estratos sociais mais abastados que emigraram em menor quantidade e com outras motivações.

${ }^{25}$ Parte desse repertório é retratada, de maneira caricata e bem-humorada, por Antônio de Alcântara Machado e Alexandre Marcondes Machado - o Juó Bananére -, sobretudo em, respectivamente, Brás, Bexiga e Barra Funda, obra publicada em 1927, e La divina encrenca, publicada em 1933.

${ }^{26}$ Esse lento processo de integração pela língua seria posteriormente intensificado devido às tensões decorrentes da pressão realizada pelo Estado brasileiro no sentido de eliminar todo tipo de estrangeirismo no país. Durante a Segunda Guerra Mundial, o Brasil se colocou contra o eixo e, por essa razão, passou a exercer controle extra sobre imigrantes da Itália, do Japão e da Alemanha, países que a ele se compunham. A partir de 1937, tais imigrantes foram o principal foco na campanha para diminuir as diferenças trazidas pelos estrangeiros residentes no Brasil. Além de controlar as liberdades civis e eliminar a ameaça comunista em muito associada aos italianos, o regime ditatorial de Getúlio Vargas intensificou o projeto de criar uma unidade nacional com base na identificação entre Estado e povo. O Decreto-Lei $\mathrm{n}^{0} 1.545$, 1939, que dispunha sobre "a adaptação ao meio nacional dos brasileiros descendentes de estrangeiros", materializava algumas dessas preocupações, como em seu artigo relacionado à educação: "Incumbe ao Ministério da Educação e Saúde: a) promover, nas regiões onde preponderarem descendentes de estrangeiros, e em proporção adequada, a criação de escolas que serão confiadas a professores capazes de servir os fins desta lei; b) subvencionar as escolas primárias de núcleos coloniais, criadas por sua iniciativa nos Estados ou Municípios; favorecer as escolas primárias e secundárias fundadas por brasileiros; c) orientar o preparo e o recrutamento de professores para as escolas primárias dos núcleos coloniais; d) estimular a criação de organizações patrióticas que se destinem à educação física, instituam bibliotecas de obras de interesse nacional e promovam comemorações cívicas e viagens para regiões do país; e) exercer vigilância sobre o ensino de línguas e da história e geografia do Brasil; f) distribuir folhetos com notícias e informações sobre o Brasil, seu passado, sua vida presente e suas aspirações" (BRASIL. Decreto-Lei ${ }^{\circ}{ }^{1}$.545, de 25 de agosto de 1939. Dispõe sobre a adaptação ao meio nacional dos brasileiros descendentes de estrangeiros. Diário Oficial da União, Brasília, seção 1, 28 jul. 1939).
} 
Nascidos brasileiros,${ }^{27}$ foram beneficiados pelos saberes e bens adquiridos por seus parentes, embora nem todos possam ser comparados a alguns de seus primos ricos, como os herdeiros das famílias Crespi e Matarazzo. ${ }^{28}$ Primeiramente, aprenderam o português como língua materna, situação que diferenciou a experiência cotidiana das duas gerações a ponto de preocupar os mais velhos, que passaram a se empenhar na tarefa de ensinar sua língua e transmitir elementos de sua cultura aos mais jovens, como rememora o historiador Boris Fausto:

Lembro o exemplo de imigrantes, entre os quais figuravam não poucos analfabetos, que se reuniam para ouvir a leitura dos jornais de sua comunidade [...] [os quais] continham notícias do país de origem e principalmente matérias que diziam respeito à inserção do agrupamento étnico na vida da cidade. Eram, pois, um instrumento valioso no esforço da primeira geração para manter-se fiel às raízes e buscar transmiti-las a seus descendentes. $^{29}$

Note-se que os signos oficiais nacionais - como a língua e o território - parecem integrar o repertório daqueles que deixaram a península antes mesmo que ela fosse oficialmente reconhecida como uma nação, o que não deixa de suscitar questões sobre a base de construção do sentimento de pertença nacional fora da Itália. ${ }^{30}$ As pesquisas de José Renato de Campos Araújo e de Luigi Biondi abordam aspectos dessa questão. Suas conclusões são convergentes no que se refere à construção de uma identidade nacional italiana no Brasil em diálogo com o processo instaurado na Itália. A identificação de parte da massa operária ao contingente imigrante e sua expressiva ligação com o movimento sindical, anarquista ou comunista penetraram o cotidiano dos trabalhadores, operários ou não, por meio

\footnotetext{
${ }^{27}$ Segundo a tradição jurídica brasileira do jus soli, em que o direito à nacionalidade se dá a partir do nascimento no território do país e não por jus sanguinis, baseado na parentalidade.

${ }^{28}$ Além de propriedades, herdaram o capital de fábricas construído desde a primeira geração dessas famílias (Cf. FAUSTO, Boris. Imigração..., cit.).

${ }^{29}$ Ibid., p. 37.

${ }^{30}$ ARAUUJO, José Renato de Campos. Imigração e futebol: o caso Palestra Itália. Dissertação (Mestrado em História) - Instituto de Filosofia e Ciências Humanas, Universidade Estadual de Campinas, Campinas, 1996; ARAÚJO, José Renato de Campos. Migna terra: migrantes italianos e fascismo na Cidade de São Paulo (19221935). Tese (Doutorado) - Instituto de Filosofia e Ciências Humanas, Universidade Estadual de Campinas, Campinas, 2003; BIONDI, Luigi. Entre associações étnicas e de classe..., cit.
} 
de panfletos, jornais e outros meios de comunicação, alimentando o sentimento de pertença dessa comunidade. A propaganda oficial da Itália, que assumiu tons fascistas a partir do fim da década de 1920, contrastava com esse movimento, mas também gerara adeptos ao construir a imagem de um país forte, contribuindo para o sonho de retorno de alguns deles.

Embora bastante significativa, a apropriação da língua portuguesa pelos imigrantes e seus descendentes não é o único aspecto a revelar o delicado processo de desenraizamento e enraizamento $^{31}$ vivido pelas várias gerações de sua comunidade. Todo o repertório material e simbólico por ela criado em torno da moradia, do trabalho, da religião e do lazer é parte desse movimento que marcou profundamente a vida na Barra Funda. Pode-se mesmo afirmar que um dos aspectos que confere especial singularidade ao bairro diz respeito a essas múltiplas artes do fazer cotidiano, a partir das quais os imigrantes e seus descendentes ali se estabeleceram. Dentre elas, destaca-se o futebol.

\subsection{A Barra Funda e a várzea dos ítalo-brasileiros}

O movimento de ocupação da Barra Funda tem início nas últimas décadas do século XIX, quando os técnicos da Sorocabana encontraram no bairro um espaço adequado para sua instalação, pois a várzea do Rio Tietê representava lugar intermediário tanto em relação às distâncias entre Santos e o Oeste Paulista, como em relação à topografia do Estado. Aproveitaram também o fato de que a região era praticamente desocupada, à exceção de uns poucos grupos caipiras que viviam em pequenas casas próximas aos rios - de onde retiravam sua subsistência.

A instalação da ferrovia, em 1870, desencadeou transformações em variados níveis. No que tange ao universo dos costumes, o sociólogo José de Souza Martins associa, por

\footnotetext{
31 Trata-se de um complexo equilíbrio entre o abandono e a adoção de lugares e práticas, a manutenção de algumas delas e a criação de outras. Desenraizar e enraizar são processos interligados, complexos e descontínuos que devem, portanto, ser analisados conjuntamente (Cf. SEIXAS, Jacy Alves de. Mémoire et oubli: anarchisme et syndicalisme révolutionnaire au Brésil. Paris: Ed. de la Maison des sciences de l’homme, 1992).
} 
exemplo, sua chegada à instauração do hábito de consumo de cerveja entre os trabalhadores: “Até então [eles] não dispunham de uma bebida cotidiana, nem de uma bebida de cerimônia, até porque eram pobres e o mercado, minguado [...] pela primeira vez passaria a existir uma bebida popular não estigmatizada, oposta ao que acontecia com a cachaça, que era bebida calmante do cativo. O trabalho livre [possibilitado, em grande medida, pela introdução da ferrovia] propunha o consumidor na figura do homem livre". ${ }^{32}$

Quanto ao espaço urbano, ela representou a base para a construção de novos lugares ao alterar "a geografia imaginária de referência da cidade de São Paulo", 33 processo que se deu de maneira ainda mais aguda nos bairros que a receberam, como a Barra Funda. ${ }^{34}$ Após ser literalmente dividido ao meio pelos trilhos da Sorocabana e sofrer o impacto da chegada de milhares de imigrantes, o bairro seguiu uma conformação muito particular, expressa de maneira curiosa por seus moradores. Eles contam que, em razão da instalação da ferrovia, o bairro passou a ser tratado não mais como uma unidade, mas a partir de dois segmentos que, em verdade, já pouco dialogavam entre si: a Barra Funda de baixo e a Barra Funda de cima. ${ }^{35}$

A Barra Funda de baixo correspondia ao exato limite da zona suburbana, como indicam as plantas da cidade de São Paulo da época, iniciando na Rua Salta-Salta e se estendendo pela várzea do Rio Tietê até o bairro do Bom Retiro (mapa 1). Já a Barra Funda de cima correspondia à região que, integrada aos Campos Elíseos e à Santa Cecília, convertia-se

\footnotetext{
${ }^{32}$ (A aparição do demônio na fábrica: origens do eu dividido no subúrbio operário. São Paulo: Editora 34, 2008, p. 25).

${ }^{34}$ Otto Friedrich Bollnow explicita que a construção de novos lugares se dá na medida em que o espaço não "é para o homem um meio neutro e constante, mas preenchido com significados nas relações vitais de atuações opostas, e esses significados, por sua vez, mudam de acordo com os diferentes lugares e regiões do espaço. Também esses significados não são devidos a sentimentos apenas subjetivos que o homem liga ao espaço, mas são caracteres autênticos do próprio espaço vivido [...] Cada modificação no homem condiciona uma mudança de seu espaço vivido" (O homem e o espaço. Paraná: Editora UFPR, 2008, p. 18).

${ }^{35}$ Os antigos associados do clube Anhanguera entrevistados durante essa pesquisa são também antigos moradores da Barra Funda, além de descenderem dos primeiros imigrantes chegados à região. Sua recorrente referência à divisão do bairro chamou a atenção para as práticas cotidianas de espaço reiteradas tanto em seus relatos, quanto em suas enunciações pedestres, seus caminhos pelo bairro, por assim dizer. Tais enunciações tornaram-se possibilidades para o reconhecimento dos usos que os varzeanos fizeram da várzea e da cidade (Cf. CERTEAU, Michel de. A invenção do cotidiano. Rio de Janeiro: Vozes, 2000, v. 1).
} 
no aclive que dava acesso ao bairro de Higienópolis (mapa 1). Tal configuração explica sua ligação com os limites urbanos da capital, ${ }^{36}$ uma vez que estes acompanharam a lógica de valorização territorial dos bairros localizados nas regiões mais altas da cidade, escolhidos para local de residência pela elite paulistana, desejosa de evitar os "pontos mais sujeitos às enchentes periódicas". 37

Ao contrário da ocupação da área varzeana, iniciada principalmente com a chegada dos imigrantes, a formação da Barra Funda de cima se deu a partir de 1850, por chácaras de recreio e residência de cafeicultores que deixaram o interior para se aproximarem do centro de decisões de seus negócios. As chácaras acabaram por impulsionar as pequenas oficinas e o ramo dos serviços, os quais, somados ao ramo de abastecimento de alimentos, foram os principais setores econômicos do bairro durante vários anos. A mais importante delas foi a Chácara do Carvalho, herança deixada pelo Barão de Iguape para o neto, Antônio Prado Jr., que

a colocou em reformas sob a direção de Luigi Pucci, arquiteto italiano também responsável pelo projeto do Museu do Ipiranga. Ao terminá-las, em 1902, trabalhou pela inauguração da primeira linha de bondes elétricos de São Paulo, uma vez que era também um dos sócios fundadores da Companhia Paulista de Estradas de Ferro. A linha ligaria a Barra Funda, na altura da Chácara do Carvalho, ao centro da cidade, no Largo São Bento. ${ }^{38}$

As características e necessidades desse abastado grupo social explicam por que tão rapidamente se estabeleceu uma concentração de serviços urbanos naquela região, ao contrário do que se passou na várzea. A Rua do Bosque, vizinha à Rua Anhanguera, por exemplo,

não era totalmente transitável, pois nela havia três interrupções; A primeira,

\footnotetext{
${ }^{36}$ Segundo anotações na Planta da cidade de São Paulo, de 1924 (Disponível no setor de obras raras da Biblioteca Mário de Andrade, em São Paulo). Cf. ainda: Mapa de Expansão da Área Urbanizada da Região Metropolitana de São Paulo, 1915/1929 (anexo).

${ }^{37}$ PRADO JUNIOR, Caio. A cidade de São Paulo: geografia e história. São Paulo: Brasiliense, 1989, p. 76.

${ }^{38}$ BRUNELLI, Aideli S. Urbani et al. Barra Funda. São Paulo: DPH, 2006, p. 27.
} 
a poucos metros de seu início, junto à rua Barra do Tibagi, onde uma galeria abandonada de águas pluviais impedia o trânsito de veículos - só pedestres conseguiam atravessar esse local; a segunda surgia após a rua Anhangüera, onde o antigo córrego, chamado "o esgoto", novamente interrompia o trânsito de veículos, sendo necessário contorná-lo; o terceiro obstáculo ficava na altura da rua dos Americanos - um proprietário, em questão com a prefeitura, alegando ser o "dono" de toda via, cercou-a e plantou capim no terreno, forçando os moradores a passar pela cerca e pelo capinzal, a fim de alcançarem suas moradias. ${ }^{39}$

As clivagens entre a Barra Funda de cima e a de baixo envolviam, ainda, outro importante grupo que habitava a parte alta do bairro: os negros. Até a chegada das linhas férreas, o principal contingente populacional da Barra Funda era formado por escravos, libertos e seus descendentes ali concentrados ${ }^{40}$ devido à oferta de serviços de suporte às chácaras dos cafeicultores. ${ }^{41}$ Após a abolição da escravidão, essa população não deixou o trabalho - predominantemente doméstico - que até então vinha realizando, ${ }^{42}$ e se manteve no bairro pelo menos até o fỉm dos anos 1940, quando a série de alterações econômicas e espaciais expulsou-a gradualmente da região. Sem oferecer novas ocupações no setor de serviços ou nas fábricas recém-instaladas na várzea, cujos postos foram preenchidos

\footnotetext{
${ }^{39}$ BRUNELLI, Aideli S. Urbani et al. Barra Funda, cit., p. 19-20. Por essa razão, a pavimentação e a iluminação públicas na Rua Anhanguera foram concluídas apenas ao final da década de 1950.

${ }^{40}$ Não parece haver consenso na escassa bibliografia existente sobre o início da presença negra na Barra Funda. Em alguns textos encontram-se informações sobre uma chegada maciça no início do século XX (Cf., por exemplo: JORGE, Janes et al. Paulicéia afro: lugares, histórias e pessoas. São Paulo: Secretaria Municipal de Cultura, 2008). Outra corrente, à qual nos vinculamos, indica como marco as últimas décadas do século XIX, em que, mesmo antes da abolição da escravidão, havia um contingente negro na Barra Funda vinculado ao trabalho nas chácaras dos barões do café - o que só se teria ampliado posteriormente. Segundo Rolnik: "A área Barra Funda/Campos Elísios foi, no início do século XX, o território mais caracterizadamente negro de São Paulo. Berço do samba paulista, ali se localizavam os clãs africanos urbanos, nos cortiços e casinhas [...]. O distrito de Santa Ifigênia, em 1893, concentrava a maior porcentagem de negros e mulatos - 14\% - em um momento em que São Paulo se italianizava rapidamente, com a grande imigração, e que a população negra e mulata representava menos de $10 \%$ da população total" (apud BRUNELLI, Aideli S. Urbani et al., op. cit., p. 23. Cf. também: SCHWARCZ, Lilia Moritz. Retrato em branco e negro: jornais, escravos e cidadãos em São Paulo no final do século XIX. São Paulo: Companhia das Letras, 2001).

${ }^{41}$ A eles se somavam, ainda que em menor escala, "pessoas vindas de casebres do interior do país ou dos portos estrangeiros [...] e brancos pobres que já inchavam as cidades imperiais e junto a eles aprenderiam a sobreviver na instabilidade que marcaria suas vidas também em seu novo habitat" (MARINS, Paulo César Garcez. Habitação e vizinhança: limites da privacidade no surgimento das metrópoles brasileiras. In: SEVCENKO, Nicolau (Org.). História da vida privada no Brasil: República: da Belle Époque à Era do Rádio. v. 3. São Paulo: Companhia das Letras, 1998, p. 132).

${ }^{42}$ Embora tenham prestado serviços no setor comercial, na estrada de ferro como carregadores, ou praticado o comércio ambulante de comestíveis e gêneros de primeira necessidade (BRUNELLI, Aideli S. Urbani et al., op. cit.).
} 
principalmente por imigrantes, a vida na Barra Funda de cima tornou-se inviável para eles. $\mathrm{O}$ encarecimento dos aluguéis foi o estopim para que atravessassem o rio e fossem viver em bairros como a Casa Verde e a Freguesia do Ó, onde as moradias possuíam preços mais abordáveis.

Em parte, os ítalo-brasileiros aderiram à mesma perspectiva discriminatória dos nacionais em relação aos negros. Quando alguns deles se mudaram para a Barra Funda de baixo, contrariando o fluxo que os dirigia para o outro lado do rio, tiveram, por exemplo, suas moradias apelidadas de caldeirão do inferno. Segundo veteranos da Associação Anhanguera, tais moradias figuravam como uma espécie de cortiço, ${ }^{43}$ o que, dizem eles, não era bem aceito naquela região do bairro. Assim, os moradores da Barra Funda de baixo não se diferenciavam apenas dos abastados cafeicultores da Barra Funda de cima e de seus arredores, mas também dos negros que moravam do lado de lá, ainda mais pobres. Apesar disso, não deixaram de com eles manter os mais variados tipos de relações, tendo, por exemplo, organizado por décadas o peculiar carnaval do bairro, tema que abordaremos adiante.

Acrescente-se a esse universo a forma pela qual as várzeas da cidade eram utilizadas e compreendidas por seus moradores e pelo poder público. Em conformidade com as práticas e concepções higienistas em voga desde o fim do século XIX, ${ }^{44}$ predominava a ideia de que tais regiões eram insalubres e sujas, algo patente no comentário do prefeito Washington Luís acerca da Várzea do Carmo, no centro da cidade: "uma vasta superfície chagosa, mal cicatrizada em alguns pontos, e, ainda escalavrada, feia e suja, repugnante e perigosa". ${ }^{45} \mathrm{O}$ comentário é parte do relatório elaborado pelo prefeito em 1916, pouco antes de dar início às obras de saneamento naquele local. Durante seu governo, foram decretadas várias medidas

\footnotetext{
${ }^{43}$ Localizado na Rua Anhanguera (entrevista com o Sr. William João Sandonato, realizada em 23 de maio de 2010).

${ }^{44}$ Cuja intensa divulgação se deu na gestão de Washington Luís na prefeitura (1914-1919) e no Estado (19201924).

${ }^{45}$ Apud SANTOS, Carlos José Ferreira dos. Nem tudo era italiano: São Paulo e pobreza (1890-1915). São Paulo: Annablume/Fapesp, 2008, p. 88, 91.
} 
que visavam ao controle de doenças relacionadas às inundações no perímetro urbano da capital, como a leptospirose e a febre amarela. ${ }^{46}$ É preciso acrescentar, no entanto, que tal controle representava um pouco mais para o prefeito, como se vê na continuação de seu relatório. Para ele, era na várzea que "se reunia e dormia à noite":

a vasa da cidade, numa promiscuidade nojosa, composta de negros vagabundos, de negras emaciadas pela embriagues habitual, de uma mestiçagem viciosa, de restos inomináveis e vencidos de todas as nacionalidades, em todas as idades, todos perigosos [...]. Era aí que, quando a polícia fazia o expurgo da cidade, encontrava a mais farta colheita. ${ }^{47}$

O prefeito se referia, segundo Carlos José Ferreira dos Santos, “às lavadeiras, caboclos e pretos véios", forma pela qual o autor chama a atenção para os nacionais pobres que ocupavam a várzea no exercício cotidiano de inúmeras atividades. Era, portanto, pela desqualificação das pessoas que por ali circulavam, "igualando-as ao espaço que ocupavam", que o poder público começava a justificar uma série de ações em nome da "limpeza, saúde e da segurança pública"; ações de caráter moralizador e disciplinador que visavam "a exclusão dos indesejáveis do centro da cidade". ${ }^{48}$

Já a várzea do Rio Tietê, na região suburbana da cidade, não despertava a mesma atenção das autoridades públicas naquele momento. Era ainda praticamente despovoada no início do século XX em razão de seu solo argiloso; além disso, por estar sempre sujeita à "enchente brava", ${ }^{49}$ foi durante anos ocupada apenas por chácaras de "vacarias" (mapa 1): “[a várzea] era lugar de vacas de leite. [...] e existiam buracos de extração de areia, os buracos

\footnotetext{
${ }^{46}$ Para explorar as práticas e concepções higienistas em São Paulo e Rio de Janeiro, cf. MOTA, André. Tropeços da medicina bandeirante: São Paulo, 1892-1920. Tese (Doutorado) - Faculdade de Filosofia, Letras e Ciências Humanas, Universidade de São Paulo, São Paulo, 2001; COSTA, Jurandir Freire. Ordem médica e norma familiar. Rio de Janeiro: Edições Graal, 1999; MERHY, Emerson E. O capitalismo e a saúde pública: a emergência das práticas sanitárias no Estado de São Paulo. Campinas: Papirus, 1987.

${ }^{47}$ Relatório de Washington Luis, 1916, apud OLIVEIRA, Maria Luiza Ferreira de. O registro dos limites da cidade: imagens da Várzea do Carmo no século XIX. Anais do Museu Paulista, São Paulo, v. 6-7, p. 37-59 (1998-1999), 2003.

${ }^{48}$ SANTOS, Carlos José Ferreira dos. Nem tudo era italiano..., cit., p. 91.

${ }^{49}$ Entrevista realizada com a Profa. Dra. Odette Seabra, realizada em 20 de maio de 2011.
} 
que a extração de areia provocou acabavam ficando vazios". 50

Assim, exceção feita ao período das cheias - fonte de preocupação intermitente dos urbanistas de espírito sanitarista do início do século, resultando na retificação de um pequeno trecho do Tietê -, a várzea não sofreu nenhuma grande modificação urbana até pelo menos o fim dos anos $1940 .{ }^{51}$ Isso permitiu que atividades de lazer e de subsistência nascidas nos séculos anteriores nela se mantivessem até, pelo menos, a instalação das avenidas marginais. Assim as pescarias, os passeios, os piqueniques, os banhos, as lavagens de roupas e utensílios domésticos e a coleta de areia e pedregulho para uso nas olarias dos arredores, próprias do cotidiano da cidade no século XVIII, adentraram o século XX. ${ }^{52} \mathrm{~A}$ não intervenção na várzea do Tietê naquele momento permitiu também que práticas novas como o futebol fossem integradas a essa dinâmica num local bastante adequado para sua realização.

No entanto, um processo semelhante ao que havia ocorrido com os grupos reprimidos na Várzea do Carmo também se anunciava naquela região, de modo que à desvalorização social do espaço da várzea do Rio Tietê correspondeu uma progressiva desvalorização de seus moradores. É nessa medida que se pode compreender o teor pejorativo do termo varzeano, tratava-se de um estigma que remetia o habitante à área desvalorizada. Faz-se necessário notar, porém, que se desvalorizava a várzea enquanto realidade geográfica natural, mas vislumbrava-se para ela usos muito próximos aos implementados na Várzea do Carmo.

\footnotetext{
${ }^{50}$ Ibid.

${ }^{51}$ Além do controle de enchentes, tal iniciativa já visava à valorização econômica da região, o que se daria, posteriormente, a partir da cessão do terreno para a Light and Power, que exploraria o potencial energético do rio, lotearia parte da várzea para habitação e cederia outra para a instalação de fábricas. A retificação do trecho foi concluída em 1919 (Cf. SEABRA, Odette Carvalho de Lima. Os meandros dos rios nos meandros do poder: Tietê e Pinheiros: valorização dos rios e das várzeas na cidade de São Paulo. Tese (Doutorado) - Faculdade de Filosofia, Letras e Ciências Humanas, Universidade de São Paulo, São Paulo, 1987).

${ }^{52}$ Para compreender os antigos usos da região do Rio Tietê, cf.: JANES, Jorge. Tietê, o rio que a cidade perdeu: São Paulo, 1890-1940. São Paulo: Alameda, 2006.
} 


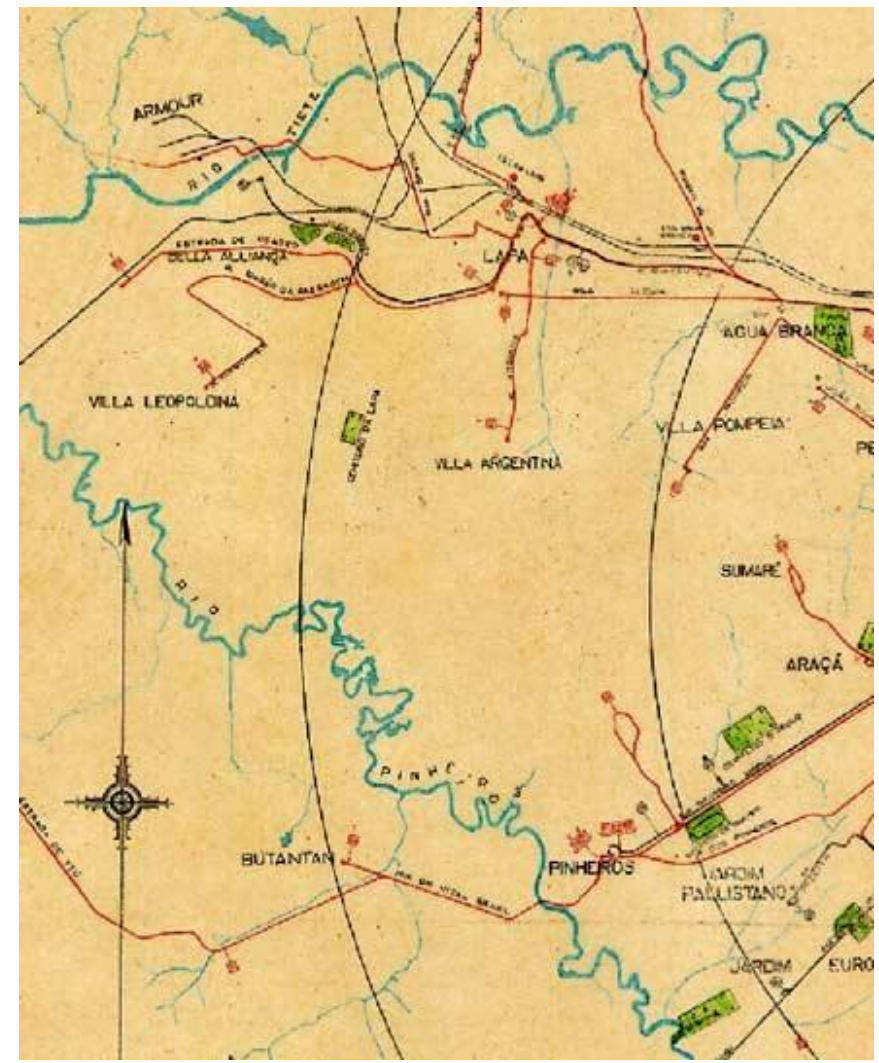

Figura 1 - Rios Tietê e Pinheiros antes da retificação, em 1943. (Fonte: Prefeitura de São Paulo) ${ }^{53}$

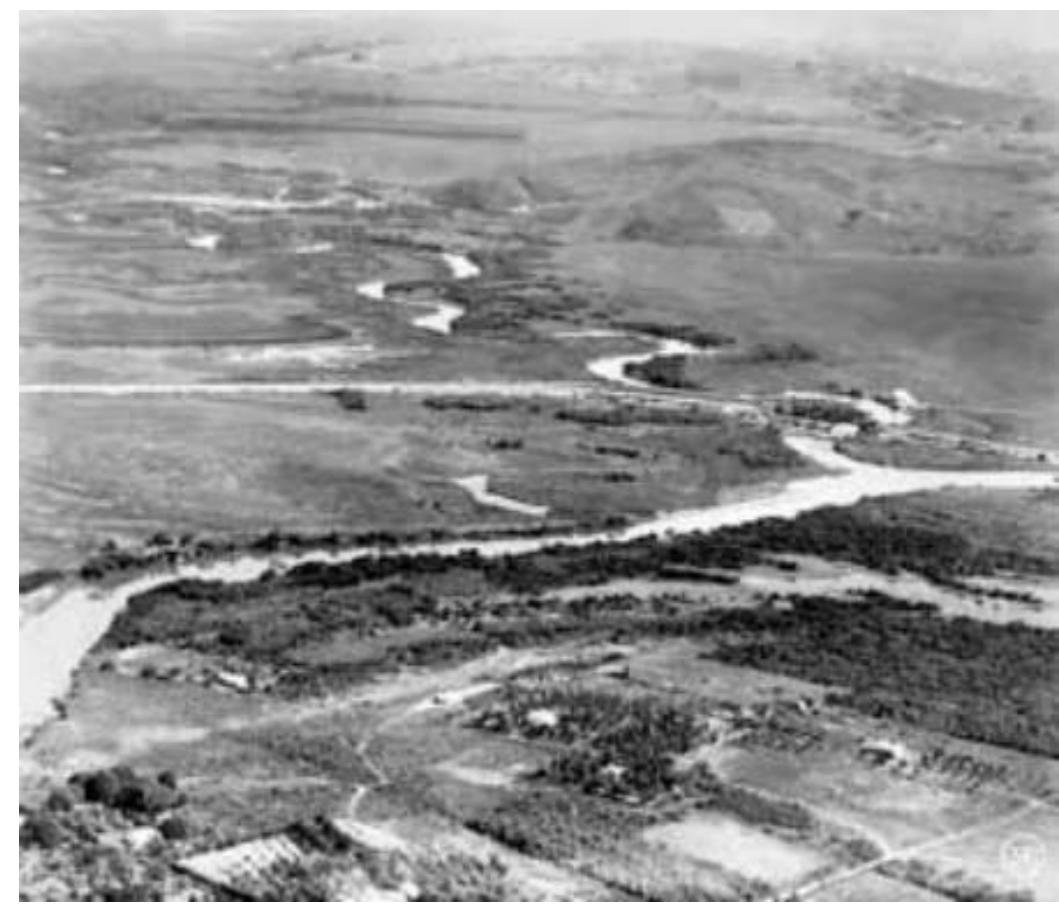

Figura 2 - Rio Tietê na cidade de São Paulo, ainda cheio de meandros no início do século XX. Foto anônima. (Fonte: Prefeitura de São Paulo) ${ }^{54}$

${ }^{53}$ Disponível em: <http://atlasambiental.prefeitura.sp.gov.br>. Acesso em: 10 jan. 2013.
${ }^{54}$ Disponível em: <http://atlasambiental.prefeitura.sp.gov.br>. Acesso em: 10 jan. 2013. 
É em meio a tal universo que se pode compreender a classificação da Barra Funda em de cima e de baixo por seus moradores e até mesmo pela prefeitura, que registra, em 1943, o termo "Várzea da Barra Funda" para se referir à região baixa em uma das plantas da cidade. ${ }^{55}$ Essa dupla designação não foi apenas fruto das diferenças topográficas do bairro, realçadas com a chegada da ferrovia. Ela indica um pouco mais. Referir-se à Barra Funda a partir de suas unidades revela a percepção de seus moradores acerca do processo de segmentação social ocorrido no bairro, ${ }^{56}$ segmentação baseada na separação de, no mínimo, três grupos com identidades sociais diferenciadas: os negros, os imigrantes e a elite cafeicultora.

Para Mônica Raisa Schpun, “é justamente a partir da instalação da oligarquia rural na cidade que os cidadãos são "preparados para repartir o espaço da cidade de forma anônima, mas sem deixar de exibir, pelo modo de aparição pública, suas identidades sociais". ${ }^{57}$ Foi então nesse terreno, marcado por transformações e conflitos - entre a Barra Funda de cima e a de baixo, entre a face urbana e a suburbana, e entre diferentes usos e compreensões da várzea -, que se estabeleceu parte fundamental do que veio a ser conhecido como o futebol de várzea da cidade. E ele não ficaria imune nem às transformações, nem aos conflitos presentes na cidade.

\subsection{A várzea se apropria do futebol}

Das novidades que chegaram a São Paulo nos primeiros anos do século XX, poucas receberam adesão tão significativa quanto o futebol. Talvez apenas o teatro musicado e o

\footnotetext{
${ }^{55}$ Planta da cidade de São Paulo e municípios circunvizinhos, organizada pela repartição de eletricidade da The São Paulo Tramway Light and Power, 1943. Disponível em: <http://smdu.prefeitura.sp.gov.br/historico_ demografico/img/mapas/1943.jpg>. Acesso em: 15 set. 2012.

${ }^{56} \mathrm{Ou}$, em outros termos, ela indica a construção de outra espacialidade, "metafórica", no "texto claro da cidade planejada e visível" (CERTEAU, Michel de. A invenção do cotidiano, cit., p. 172).

${ }^{57}$ SCHPUN, Mônica Raisa. Beleza em jogo: cultura física e comportamento em São Paulo nos anos 20. São Paulo: SENAC/Boitempo, 1999, p. 21.
} 
cinema $^{58}$ tenham despertado interesse equivalente entre os mais diversos grupos sociais que apenas começavam a tomar forma na cidade. Nacionais e imigrantes, brancos e negros organizaram associações esportivas e dedicavam parte de seu tempo a usufruir do futebol. Se no estrato social mais abastado da cidade temos a fundação do São Paulo Athletic em 1888 (visando, inicialmente, apenas à prática do críquete) e do Clube Atlético Paulistano em 1900, no estrato dos mais pobres, o União Futebol Clube apresentava, já em 1901, Formiga e Simão, "um mulato e um negro que formaram uma dupla de ataque muito conhecida". 59

Segundo a Liga Paulista de Futebol, existiam no estado de São Paulo “aproximadamente 2 mil clubes praticantes de futebol” em $1914 .{ }^{60} \mathrm{E}$ no ano seguinte, o jornal O Estado de São Paulo anunciava, num domingo “47 jogos envolvendo 94 clubes, 188 times e 1.068 jogadores". ${ }^{61}$ Esses números indicam que o processo de apropriação do futebol extrapolou barreiras socioculturais e se deu de maneira concomitante entre os diferentes grupos que compunham a cidade, contrariando "uma certa visão oficial [que] privilegiou as elites como protagonistas da história brasileira e apegou-se à ficção da concessão de direitos promovida pelos setores dominantes". ${ }^{6}$

\footnotetext{
${ }^{58}$ Para Lúcia Gama, o "cinematógrafo do salão de variedades [...], o teatro musicado, picadeiros e pavilhões de circo" também mobilizaram setores das camadas médias e populares da cidade (Sociabilidade e produção cultural: uma caminhada pelos vértices e pela história do triângulo central. Cidade: Revista do Departamento do Patrimônio Histórico/SMC, São Paulo, ano 5, n. 5, jan. 1998, p. 43). Sobre as transformações nas formas de lazer e entretenimento da primeira metade do século XX, cf. também: RAGO, Margareth. A invenção do cotidiano na metrópole: sociabilidade e lazer em São Paulo, 1900-1950. In: PORTA, Paula (Org.). História da cidade de São Paulo: a cidade na primeira metade do século XX, 1890-1954. São Paulo: Paz e Terra, 2004. v. 3, p. 387-435. Sobre as semelhanças entre a forma como o futebol e o cinema foram apropriados no Rio de Janeiro, cf. MELO, Victor. Futebol e cinema: duas paixões, um planeta. In: ALVITO, Marcos; MELO, Victor (Orgs.). Futebol por todo o mundo: diálogos com o cinema. 1. ed. Rio de Janeiro: FGV, 2006, p. 9-26.

${ }^{59}$ SANTOS NETO, José Moraes dos. Visão de jogo: primórdios do futebol no Brasil. São Paulo: Cosac Naify, 2002, p. 53. Não se pode esquecer, ainda, daqueles que representavam a comunidade imigrante. O periódico $A$ Fanfulla parece ter registrado vários embates entre clubes da comunidade ítalo-brasileira em suas páginas já na primeira década do novo século.

${ }^{60}$ Apud NEGREIROS, Plínio José L. de Campos. Resistência e rendição..., cit., p. 51.

${ }^{61}$ Ibid.

${ }^{62}$ FRANCO Jr., Hilário. A dança dos deuses: futebol, sociedade e cultura. São Paulo: Cia das Letras, 2007, p. 61.
} 
De caráter urbano e vocação não exclusivista, o futebol tornava-se, assim, um empreendimento coletivo marcado pelo entusiasmo e pelo engajamento de representantes desses diversos segmentos sociais. Pela mesma razão, ele se tornava também uma prática heterogênea e fragmentada. Ao se tornar parte dos repertórios culturais de grupos como a elite cafeicultora, os nacionais pobres - com destaque para os ex-escravos - e os recém-chegados imigrantes, sobre o futebol recaíram conteúdos bastante diversificados durante os anos iniciais do século de ares modernos. ${ }^{63}$

No caso da elite cafeicultora, tal apropriação se deu em diálogo com as transformações advindas da passagem de um meio de vida rural para o urbano. O rápido crescimento da cidade de São Paulo alterara códigos e padrões de representação social, o que exigia a criação de estratégias para que ela pudesse afirmar sua distinção também na cidade. É nesse sentido que se pode compreender a forma como o futebol foi por ela recebido. Tratavase de incorporá-lo como um elementos que compunham sua distinção social, como algo que lhes era próprio.

É nesse sentido que se pode compreender a tentativa de afirmação de antigas hierarquias por setores da elite diante de contatos cada vez mais regulares com os populares na cidade. A cidade se modificava, mas o "passado escravista, ainda recente, palpitava nos tratos sociais e na atitude discricionária, peremptória", diz Sevcenko. ${ }^{64}$ Ao analisar algumas posições da incipiente imprensa esportiva nos primeiros anos do século XX, Santos Neto

\footnotetext{
${ }^{63}$ Para explorar a difícil noção de modernidade, parte-se aqui da imagem utilizada por Marshall Berman, que, em diálogo com Baudelaire, afirma que a experiência moderna é a experiência da perda do halo. Para o poeta, não havia mais inocentes ou escolhidos em face das transformações decorrentes da reurbanização de Paris. A modernidade apresentava-se como o tempo novo, em que se abandonavam as dualidades e a transcendência: arte e mundo, beleza e realidade, espiritual e material. Nesse sentido, a rua, elemento que condensava todos esses aspectos, figurava como seu espaço. Cf. BERMAN, Marshall. Tudo que é sólido desmancha no ar: a aventura da modernidade. São Paulo: Companhia das Letras, 1996. Para uma análise de como a modernidade passa a integrar o cotidiano de cariocas e paulistanos a partir do fim do século XIX, cf. SEVCENKO, Nicolau. A capital irradiante, técnica, ritmos e ritos do Rio. In: ___ (Org.). História da vida privada no Brasil: República: da Belle Époque à Era do Rádio. São Paulo: Companhia das Letras, 1998, v. 3, p. 513-618; e, do mesmo autor, Orfeu extático na metrópole: São Paulo, sociedade e cultura nos frementes anos 20. São Paulo: Companhia das Letras, 1992.

${ }^{64}$ SEVCENKO, Nicolau. Orfeu extático na metrópole..., cit., p. 31.
} 
revela a forma que as "atitudes discricionárias" assumiram no futebol. Para ele, periódicos como $O$ Estado de S. Paulo utilizaram sistematicamente o tom pejorativo para falar da prática esportiva pelos populares, expressando uma

política consciente para separar [...] dois universos futebolísticos. Para os primeiros jornalistas esportivos, assim como para os primeiros dirigentes, havia o "grande futebol", o das elites, e o "pequeno futebol" [...] Uns eram os dignos representantes do nobre esporte bretão, e os outros não estavam à altura do reconhecimento oficial e da igualdade na forma de tratamento. Os times populares eram vistos como brutos, incapazes de seguir as regras de conduta do futebol e dos gentlemen ingleses, e por várias vezes foram até mesmo ridicularizados pelas folhas como um bando de jogadores que davam chutões para o alto, sendo chamados de "canelas negras". ${ }^{5}$

Os canelas negras, representantes do pequeno futebol, eram desqualificados em seus gestos quando comparados aos praticantes do grande futebol: os aristocráticos sportmen. ${ }^{66} \mathrm{~A}$ suposta e difundida incapacidade dos primeiros em cumprir as regras de conduta do futebol sustentava a ideia de que os últimos seriam os legítimos representantes do esporte trazido da Europa, uma vez que apenas os seus gestos estariam de acordo com uma alegada etiqueta, ou mesmo com as regras que o organizavam. Hilário Franco Júnior mostra que condutas semelhantes marcaram a chegada do esporte no Rio de Janeiro: “o primeiro número de um novo periódico lançado no Rio de Janeiro declarava solenemente que 'o futebol é um esporte que só pode ser praticado por pessoas da mesma educação e cultivo. [Se formos] obrigados a jogar com um operário [...] a prática do esporte torna-se um suplício, um sacrifício, mas nunca uma diversão". 67

Vale ressaltar que a seção de esportes de O Estado de S. Paulo foi, durante anos, chefiada pelo jornalista Mário Cardim, um dos fundadores do Clube Atlético Paulistano. ${ }^{68}$ Para Cardim e outros representantes daquela elite, alegadas diferenças na gestualidade

\footnotetext{
${ }^{65}$ SANTOS NETO, José Moraes dos. Visão de jogo..., cit., p. 53.

${ }^{66}$ FRANCO JÚNIOR, Hilário. A dança dos deuses ..., cit., p. 65.

${ }_{67}^{67}$ Sports, 6 ago. 1915, apud FRANCO JÚNIOR, Hilário. A dança dos deuses..., cit., p. 63.

${ }^{68}$ RIBEIRO, André. Os donos do espetáculo: histórias da imprensa esportiva no Brasil. São Paulo: Editora Terceiro Nome, 2007, p. 39.
} 
figuravam como meio de distinção entre grupos sociais, pois se tornava cada vez mais difícil manter ativas as distinções manifestas, por exemplo, na ocupação do espaço social. Partilhar com os populares a Várzea do Carmo ${ }^{69}$ e outros espaços para a prática do futebol poderia causar confusão sobre os lugares sociais de cada grupo. Daí que recursos como pequenas notas na imprensa tornaram-se cada vez mais comuns para distinguir os futebolistas que dividiam o mesmo espaço de jogo: “Um 'ground' em polvorosa - Na várzea do Carmo, dois ‘times' anônimos de menores desocupados se empenharam ontem às três e meia horas da tarde, num 'match' de 'futebol', com entusiasmo belicoso de dois cães na disputa de um osso". ${ }^{70}$ Anônimos, menores e desocupados eram os atributos a que mais recorriam os jornalistas quando se referiam ao futebol "pequeno".

Afora o posicionamento apresentado em $O$ Estado de $S$. Paulo nesse período, uma concreta separação espacial passou a ser empreendida por aqueles setores para evitar o “indesejável compartilhamento de espaços públicos"71 que a cidade, envolta em novos tempos, parecia possibilitar. Era preciso traduzir diferenças sociais em distâncias físicas. Quem primeiro conseguiu realizar tal tradução, já no ano de 1901, foi o Clube Atlético Paulistano, quando promoveu, "em conjunto com a prefeitura municipal, a transformação do Velódromo existente na cidade em campo de futebol". ${ }^{72}$ Esse parece ter sido um dos primeiros passos rumo à separação e à especialização dos espaços de jogo da cidade com o apoio da administração municipal, que, não se pode deixar de notar, tinha entre seus membros assíduos frequentadores ou mesmo sócios das associações do chamado grande futebol. ${ }^{73}$

\footnotetext{
69 Segundo notícia de A Gazeta Esportiva, de março de 1930, a várzea do Carmo possuía 8 campos de futebol. Sem regulação do poder público, mais interessado em aterrar a várzea, o uso do espaço era indiscriminado, o que possibilitou que o futebol fosse ali praticado pelos mais diferentes clubes da cidade.

${ }^{70}$ O Estado de S. Paulo, 14 ago. 1915, apud NEGREIROS, Plínio. Resistência e rendição..., cit., p. 52.

71 Ibid.

72 SANTOS NETO, José Moraes dos. Visão de jogo..., cit., p. 49. Cf. também: ANTUNES, Fátima M. R. Ferreira. Do velódromo ao Pacaembu: o movimento esportivo em São Paulo e a trajetória do futebol. Cidade: Revista do Departamento do Patrimônio Histórico/SMC, São Paulo, ano 5, n. 5, jan. 1998.

${ }^{73}$ Caso do futuro prefeito Washington Luís, frequentador do Clube Atlético Paulistano e da família Prado, associada ao mesmo clube.
} 
É nesse contexto de progressivo abandono das várzeas ${ }^{74}$ pelos oligarcas que a noção de futebol de várzea começou a circular, ainda segundo Santos Neto. A locução vinha para designar especificamente a prática dos times populares que continuaram a utilizar os espaços de vazão dos rios para o jogo. Embora não tenham sido encontrados documentos diretamente associados à construção de tal acepção, a alcunha de varzeanos para designar aqueles que moravam na várzea ou que dela usufruíam já circulava com claro conteúdo pejorativo entre os anos 1910 e 1920, como vimos nas ações do poder público. Curiosamente, tais sujeitos das camadas mais pobres da população - principalmente os moradores dos bairros da Barra Funda e do Bom Retiro, na várzea do Rio Tietê - não rejeitaram a denominação associada ao seu futebol. Muito embora representasse uma série de conflitos, ela foi por eles incorporada tornando-se uma afirmação identitária forte e corrente, prenhe de conteúdos novos já ao final dos anos 1920, a ponto de um antigo morador da Barra Funda assim rememorá-la: "[era] futebol de várzea, naquele tempo. Nem amador não se chamava". ${ }^{75}$

\subsection{O clube Anhanguera: uma experiência associativa}

O futebol praticado na várzea entre os populares já era uma realidade em janeiro de 1928, quando Saverio Russo, Bartholomeu Maggi e Ezzio Marchetti reuniram-se na alfaiataria deste último com o intuito de criar um clube para praticar o esporte. A ideia dos rapazes surgira após seu desentendimento com a diretoria do Grupo Esportivo Carlos Gomes ${ }^{76}$ do qual até então faziam parte: os diretores teriam discordado da sugestão por eles apresentada de instalar um bar nas dependências sociais do clube, o que os levou a criar outra

\footnotetext{
${ }^{74}$ Além da Várzea do Carmo, havia a Chácara Dulley e a Chácara White, ambas na várzea do Rio Tietê, no Bom Retiro. Por outro lado, além do velódromo, o futebol oficial e de elite passou a utilizar também o antigo hipódromo da cidade e o Parque Antarctica.

${ }_{75}$ Depoimento de Alfredo Campos, morador da Barra Funda, descrevendo sua infância e juventude no bairro. Museu da Pessoa. Disponível em: <http://www.museudapessoa.net/_index.php/historia/5284-historia-de-vida? historia=integra>. Acesso em: 11 jan. 2013.

${ }^{76}$ Fundado em 1913 por ítalo-brasileiros.
} 
associação na qual pudessem usufruir de um bar sempre abastecido. Assim nasceu o clube Anhanguera, batizado com o nome da rua onde fora fundado e com as cores rubro-negras. Assim nasceu também a rivalidade que colocaria em disputa constante os clubes irmãos da comunidade ítalo-brasileira instalada na Barra Funda de baixo.

Após a reunião de fundação, uma série de exigências se impôs aos rapazes. Além das providências que envolviam a obtenção da licença para o funcionamento do clube, ${ }^{77}$ fazia-se necessário compor um considerável grupo de associados, eleger diretores e presidente, redigir os estatutos $^{78}$ e, ainda, obter espaços para estabelecer uma sede social e uma sede esportiva. Tudo indica que eles buscavam reunir elementos para caracterizar a fundação de uma associação esportiva, e não de uma agremiação. Embora essas duas designações fossem, em geral, utilizadas como sinônimas, alguma diferença as distanciava à época: segundo os órgãos estatais que regulavam as organizações civis para o lazer, a agremiação reunia os interessados na prática de apenas uma modalidade esportiva; já a associação, mais complexa, era organizada fundamentalmente sob interesses sociais, o que lhe impunha a missão de desenvolver outras atividades além dos esportes. ${ }^{79}$ Em verdade, as associações não eram modalidades de organização desconhecidas entre os imigrantes europeus instalados na várzea, sobretudo entre aqueles advindos da península itálica que, desde o fim do século XIX, vinham

\footnotetext{
77 "Como: o requerimento da agremiação interessada - contendo seus estatutos sociais - e principalmente o aval da autoridade mais próxima do local onde a sociedade requisitante se instalava, os Delegados de Polícia responsáveis pelos bairros" (SIQUEIRA, Uassyr de. Clubes e sociedades dos trabalhadores do Bom Retiro: organização, lutas e lazer em um bairro paulistano (1915-1924). Dissertação (Mestrado) - Departamento de História do Instituto de Filosofia e Ciências Humanas, Universidade Estadual de Campinas, Campinas, 2002).

${ }_{70}^{78}$ Infelizmente não localizados durante a pesquisa.

${ }^{79}$ Segundo a Profa. Dra. Odette Seabra: "O grêmio reúne em torno de uma prática e a associação reúne [...] morador, família, reúne tudo. Ela não é só um time. O que se formava sem parar eram grêmios [...] os jovens queriam jogar, então eles não fundam clube, eles formam um grêmio e vão [...] jogar. Daí eles procuram quem queira jogar. Aliás, acho que tem uma norma. Foi normatizado na década de 30 porque foi exigido dos clubes que eles tivessem várias coisas, eles tinham que formar uma associação. Eles tinham que ser uma associação, eles tinham que ter uma biblioteca, tinham que ter uma porção de coisas pra funcionar, pra ser uma associação" (entrevista com a Profa. Dra. Odette Seabra, realizada em 20 de junho de 2011). Seu comentário aponta não só para a força da normatividade estatal em relação às organizações esportivas, sobretudo a partir do Estado Novo, mas também para a maior formalidade institucional das associações em comparação com as agremiações. Aponta ainda, mesmo que indiretamente, para os interesses em jogo para agremiados ou associados, como veremos adiante.
} 
desenvolvendo

um tecido muito denso de associações culturais, artísticas, [...] de ajuda mútua, além das escolas. Essa rede associativa, organizada segundo as diversas origens e sensibilidades políticas, liga-se não somente a uma grande circulação de jornais em língua estrangeira, mas também a uma comunicação intercomunitária. $^{80}$

Nessas entidades circulavam os mais diversos interesses, desde "o combate ao alcoolismo, a luta contra os açambarcadores de alimentos ou o movimento pelo barateamento do preço dos aluguéis", 81 até a oferta de atividades como o teatro e a dança. Embora diversas, essas "práticas recreativas, sindicais e esportivas não necessariamente se auto-excluíam e, em algumas ocasiões, se entrecruzavam no cotidiano dos trabalhadores — mantendo relações entre si e atuando de forma semelhante", ${ }^{82}$

Foi nessa atmosfera associativa que o Anhanguera se organizou. E tão logo a sede social do clube foi provisoriamente estabelecida à Rua do Córrego, $\mathrm{n}^{\mathrm{o}} 5$ (mapa 2), ela se tornou um espaço central na sociabilidade de seus membros, sobretudo para o presidente da associação e seus diretores sociais e esportivos, ao funcionar como o espaço onde se realizavam as assembleias semanais. Estas ocorriam nas noites de segunda-feira e não raramente ultrapassavam três horas de duração. Entre 1928 e 1934, suas pautas privilegiavam basicamente três momentos: o encaminhamento de questões burocráticas - principalmente as propostas de novos associados, quase sempre interessados em integrar o time de futebol -, a resolução de conflitos entre sócios e a organização de eventos sociais.

Após estabelecerem seu tempo e espaço de reunião, outras necessidades emergiram e tornaram-se centrais entre os organizadores do Anhanguera. Em uma das primeiras assembleias de outubro de 1928, por exemplo, o então presidente Antônio Vignola pede à

\footnotetext{
${ }^{80}$ SCHPUN, Mônica Raisa. O cinema mudo em São Paulo..., cit., p. 74. Cf. ainda: BIONDI, Luigi. Entre associações étnicas e de classe..., cit.

${ }^{81}$ SIQUEIRA, Uassyr de. Clubes e sociedades dos trabalhadores do Bom Retiro..., cit., p. 49.

${ }^{82}$ Cf. SIQUEIRA, Uassyr de. Entre maxixes, peladas e palavras de ordem..., cit., p. 78.
} 
diretoria que "se entre num accordo a respeito das photographias $d[o s] 1^{\text {os }}$ e $2^{\text {os }}$ quadros de foot-ball e o de diretores", 83 o que revela o interesse dos associados em iniciar o novo clube conforme a etiqueta relacionada ao costume de registrar, ano a ano, as imagens de jogadores e dirigentes dos clubes. Durante a mesma assembleia, o secretário, Sr. Jeronymo Ferro, anteriormente incumbido de pesquisar os preços para o serviço, é então chamado para apresentar o orçamento. $\mathrm{O}$ valor foi unanimemente compreendido como exorbitante pelos presentes, o que indica não apenas o descompasso entre o serviço e a receita do clube, mas, principalmente, a falta de familiaridade dos associados com aquele universo. Não havia alternativa, portanto, senão recusar o serviço. Logo em seguida, porém, o associado Antonio Chieregati

muito acertadamente ideiou que cada director trouxesse a sua photografia a esta secretaria [para mandar] collocar em um quadro como sóe. Desta forma, sahiria o serviço mais perfeito e muito mais vantajoso no preço. Como todos achassem que o Sr. Chieregati fosse feliz apresentando essa bella ideia, foi unanimemente acceita. ${ }^{84}$

A solução caseira, unanimemente aceita, chama a atenção tanto pela economia que representava entre os presentes, quanto pela afirmação de que o serviço sairia mais perfeito. Embora não se possa precisar a que exatamente se referia Chieregati ao apostar em tal perfeição, a situação oferece indícios de como se movimentavam os associados na organização do novo clube: se por um lado desejavam partilhar do universo simbólico em torno da prática do esporte na cidade, por outro começavam a encontrar lugar um pouco diferente daquele em que provavelmente se espelhavam. ${ }^{85}$

A construção de um painel de fotografias estava longe, no entanto, de ser a última das demandas durante o período de constituição do clube. Mas algumas se tornaram tão

\footnotetext{
${ }^{83}$ Atas da Associação Atlética Anhanguera, 15 out. 1928.

${ }^{84}$ Atas da Associação Atlética Anhanguera, 15 out. 1928.

${ }^{85}$ Há ainda dois elementos a serem considerados sobre a questão: após alguns anos, as fotografias coletivas enfim fizeram parte do repertório material do clube; ao mesmo tempo, os painéis montados a partir de fotografias individuais não deixaram de representar recurso entre os anhangueristas, como se vê no anexo B.
} 
complexas que não dependeram apenas de soluções caseiras para sua resolução. Esse foi o caso diante da necessidade de buscar endereço mais estável para abrigar a sede social. A partir do apoio de um membro do clube e de seu sócio, ambos economicamente bem estabelecidos no bairro, ela foi alocada, já em 1929, em um espaço definitivo, algo tão raro quanto fundamental para a estabilidade de uma associação esportiva à época. O primeiro era Matheus Sabatini, um dos diretores sociais do Anhanguera; o segundo, Miguel Vignola, que ao clube se vincularia posteriormente. Miguel era irmão de Antonio Vignola, o presidente da associação à época.

De acordo com antigos associados, Sabatini e Vignola cederam um dos terrenos de sua propriedade, localizado no cruzamento entre a Rua Anhanguera e a Rua do Bosque (mapa 2), para a construção de um prédio especialmente destinado a sediar a Associação Atlética Anhanguera. Alguns relatos dão conta, no entanto, de que o mesmo prédio abrigou em seu andar térreo, durante anos, o bar Invicta do "Sr. Aires", ${ }^{86}$ que não parece ter tido relação com o clube. Por esse motivo, a associação teria sido alocada no primeiro andar, o sobrado.

Entregue ao final de 1929, o prédio possuía "todas as condições necessárias ao funcionamento do clube: salão de baile, w.c. feminino, palco para representação de dramas e comédias e local para a orquestra dos bailes", segundo atas recentes da associação. ${ }^{87} \mathrm{O}$ foco e o detalhamento do registro sugerem que possuir sede própria e as condições necessárias ao seu funcionamento, com destaque para aquelas que viabilizavam a presença feminina, representava um diferencial em relação a outros clubes da várzea. E isso não apenas nos anos em que tais dados foram rememorados, como se entrevê na notícia publicada em fevereiro de 1930, no suplemento esportivo de A Gazeta:

A Associação Atlética Anhanguera, uma das mais representativas sociedades

\footnotetext{
${ }^{86}$ Entrevista com o Sr. Pedro Cardoso, realizada em 8 de setembro de 2012.

87 Atas da Associação Atlética Anhanguera, 2 jan. 1981. Por ocasião de nova mudança de endereço da sede social, em 1981, a associação rememorou e registrou alguns fatos associados à antiga sede.
} 
da Barra Funda, acaba de transferir a sua sede social para a Rua Anhanguera, 34, sobrado, onde continua à disposição dos clubes da capital e do interior. A inauguração da nova sede do rubro-preto dar-se-á no próximo domingo, dia 09, constando do programa o batismo da Nova Bandeira, posse da nova diretoria, animado vesperal dançante, 'comes e bebes', etc. ${ }^{88}$

As informações selecionadas sobre a festa de inauguração e a própria iniciativa de torná-la pública revelam que tal mudança não parecia ser de pouca importância nem para o grupo fundador, nem para as famílias que financiavam o novo clube. Para Russo, Maggi e Marchetti, tal relevância parecia estar ligada ao fato de que o evento marcava a transição para um espaço novo e próprio. Vale lembrar que o clube ganharia como vizinho justamente o Grupo Esportivo Carlos Gomes, com quem dividiria, face a face, a Rua Anhanguera. ${ }^{89}$

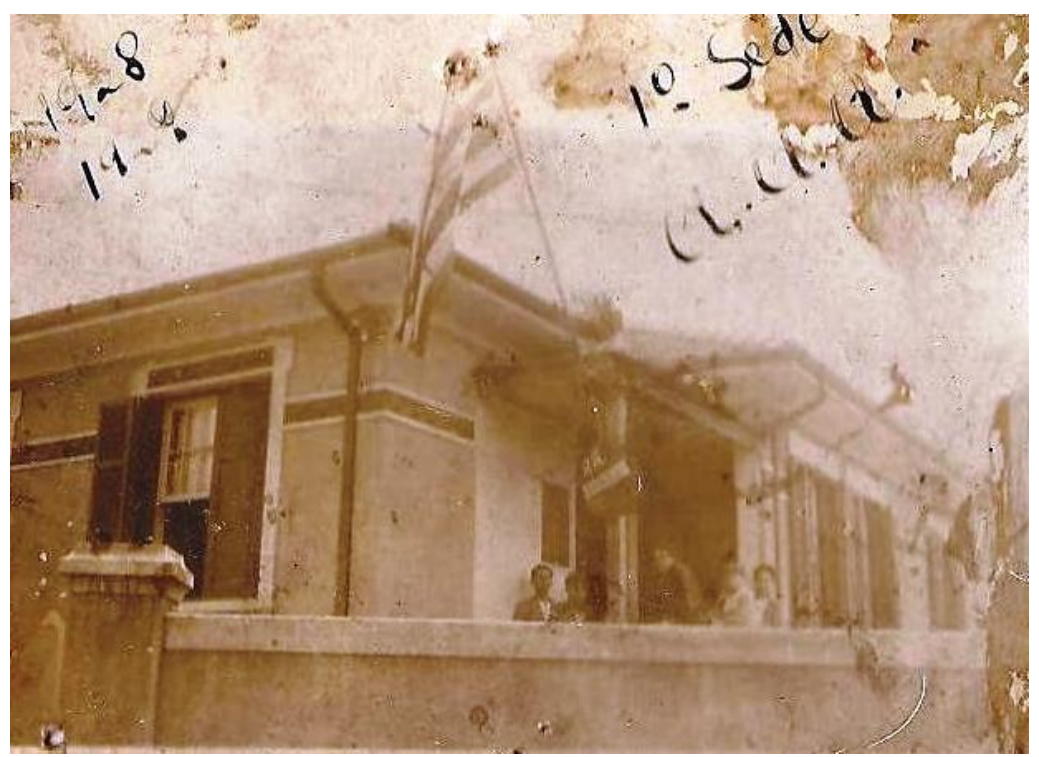

Figura 3 - Reprodução de fotografia da sede social à Rua Anhanguera, $n^{\circ} 250$ (embora o registro da fotografia a remeta a 1928, a análise de outras fontes sugere que ela seja posterior a 1930). (Fonte: Acervo do clube)

Quanto às famílias que financiavam o clube, outros elementos pareciam estar em jogo, pois delas faziam parte "os homens de dinheiro da Barra Funda", ${ }^{90}$ como ficaram conhecidos

\footnotetext{
${ }^{88}$ A Gazeta Esportiva, 2 fev. 1930, p. 11.

${ }^{89}$ Por longos trinta anos até o fechamento deste último, em 1958, em razão da perda do direito de usufruto de seu campo de futebol, à Rua dos Americanos.

${ }^{90}$ Entrevista com o Sr. William João Sandonato, realizada em 23 de maio de 2010. Admitido em 1945 como jogador do time de futebol, Sandonato passou rapidamente à presidência do clube.
} 
os Sabatini e os Vignola. Os primeiros "eram donos de grande parte da Barra Funda de baixo"; ;1 já os Vignola tinham suas atividades econômicas concentradas nas proximidades da Rua Anhanguera. Ainda segundo Sandonato:

Um dos Vignola era delegado de polícia... O Miguel Vignola morava aqui [apontando para o início da Rua Anhanguera], onde tem uma casa grande onde ainda se faz recepção. [...] o Raphael Vignola morava aqui [também apontando para o início da Rua Anhanguera]. Ele tinha a venda na frente da minha casa... Tinha também o Pedro Vignola, que jogava. ${ }^{92}$

O vínculo do Anhanguera com os negócios de tais homens de dinheiro não se resumia a esse ponto. O prédio onde a sede social do clube fora abrigada era de propriedade de Margarida Sabatini e Caetano Sabatini, provavelmente esposa e filho de Matheus. Isso talvez explique por que, durante o delicado período financeiro que se seguiu à Revolução de 1932, D. Margarida resolve:

dar quitação à sociedade, ficando todos os meses em atraso perdoados. Ficando assim a A.A.A. completamente quite com os aluguéis até esta data. Fica a pagar só o mês de outubro que terminará em 10 de novembro. Os futuros pagamentos deverão ser feitos até o dia 10 do mês subsequente ao vencido. Porém, se vencidos dois meses e a sociedade não puder quital-os, a dona do prédio reserva-se o direito de evacuar a sede sem prévio aviso. ${ }^{93}$

O perdão pode ter significado a opção por menor prejuízo diante da instabilidade econômica e do fato de que os Sabatini possuíam outros imóveis e terrenos no bairro. A capacidade de agenciar tais propriedades era bastante conhecida entre os vizinhos e foi rememorada por Sandonato com um agudo comentário: "eles tinham dinheiro, mas não davam um tostão para ninguém, sempre queriam mais". 94 Já nas lembranças do Sr. Pedro Cardoso, neto do patriarca da família Vignola, essa capacidade assume outro tom:

\footnotetext{
91 Ibid.

${ }^{92}$ Entrevista com o Sr. William João Sandonato, realizada em 23 de maio de 2010.

${ }^{93}$ Atas da Associação Atlética Anhanguera, 4 out. 1932.

${ }^{94}$ Entrevista com o Sr. William João Sandonato, realizada em 23 de maio de 2010.
} 
Meu nono Consolato Vignola foi construtor por muitos anos [...] quando tinha 40 anos morando na Anhanguera, logo depois da inundação de 1929, um senhor perguntou para ele se havia alguma casa para ele comprar na rua. Ele indicou a casa do vizinho. Uma semana depois aquele senhor toca a campainha quando o nonno ia tomar uma sopa. Ele atende. O senhor agradece a indicação e diz que comprou a casa. Tem nas mãos um saco de papel de pão que entrega para o Consolato. Estava cheio de dinheiro. Diz que é a comissão dele pela indicação da casa. O nonno diz que não precisava pagar nada, mas ele insiste dizendo que estava feliz em ter ele como vizinho e não podia deixar de pagar. O nonno aceita. O Consolato que nunca tinha visto tanto dinheiro, falou para a nonna: "Filomena daqui para frente vou ser corretor de imóveis. Ele trabalhou 50 anos como corretor na Barra Funda." Era tão conhecido que chegou a vender alguns imóveis diversas vezes, para novos proprietários. ${ }^{95}$

As versões não são congruentes, mas há nelas certa correspondência no que se refere ao dinheiro ou à capacidade de gestão dos negócios dos Vignola. Quanto aos demais envolvidos com o pagamento do aluguel da sede, o gesto de D. Margarida parecia representar um pouco mais. Os recibos, ${ }^{96}$ principal fonte de receita do clube, vinham declinando desde o início da Revolução, como indicam as medidas tomadas em agosto pelo clube:

Devido a situação anormal, motivada pela Revolução Constitucionalista, foi suspenso, desde o dia 24 de julho de 1932, o baile em nossa sociedade, até cessação do nosso movimento. Nesse período de trégua, até esta data, a sociedade não tem tido um bom andamento e em vista disso deliberou-se fazer essa sessão para se tratar da questão e ver que providências se poderiam tomar. Deliberou-se o seguinte: $1^{\circ}$. Prestação de contas que ficou marcada para a próxima $5^{\mathrm{a}}$ feira, dia $01-09-1932,2^{\circ}$. Nomear novo cobrador, provisoriamente, $3^{\circ}$. Os sócios, enquanto durar a revolução e não se dansar, pagam $3 \$ 000$ de mensalidades, $4^{\circ}$. Depois da revolução, convocar uma assembleia geral para eleger nova directoria. ${ }^{97}$

O grupo dos endinheirados - em parte coincidente com a presidência e a diretoria do Anhanguera nesses primeiros anos - era pequeno diante de seus associados. Por sua vez, estes estiveram muito mais sujeitos às instabilidades econômicas e à modificação do perfil de

\footnotetext{
${ }^{95}$ Entrevista com o Sr. Pedro Cardoso, realizada em 8 de setembro de 2012. Cardoso é neto de Consolato e sobrinho de Miguel e Antônio Satriano. Curiosamente, é o único descendente entrevistado a não fazer parte do clube.

96 Trata-se dos pagamentos mensais realizados pelos associados. Os recibos tornaram-se sinônimos de mensalidades por remeterem ao talão administrado pelo tesoureiro.

${ }^{97}$ Atas da Associação Atlética Anhanguera, 30 ago. 1932.
} 
trabalho que a nascente industrialização, a diversificação das atividades terciárias e o crescimento agudo da cidade começavam a anunciar nos anos 1930.

Ainda que o comércio fosse a ocupação mais comum entre nacionais e imigrantes, ${ }^{98}$ os associados do Anhanguera foram também trabalhadores de ofício ${ }^{99}$ pelo menos até o início dos anos 1940. ${ }^{100}$ A família Olivieri, por exemplo, que abrangia alguns dos primeiros membros do clube, trabalhou no ramo da tapeçaria desde sua segunda geração no Brasil, sobretudo na figura de Waldemar Olivieri, que inaugurou sua oficina na Rua Anhanguera em fins dos anos 1930. ${ }^{101} \mathrm{Na}$ família Satriano, por sua vez, havia um significativo número de marceneiros, entre eles os irmãos Antônio e Miguel, que ficaram responsáveis pelas estantes onde seriam alocados os instrumentos musicais da associação. Os dois irmãos ofereceram-se, logo em seguida, para também montar as primeiras cristaleiras em que se guardariam as taças e os troféus que o clube começava a reunir, em imbuia por fora e cedro por dentro, provavelmente apostando na imponência dos materiais para ganhar a concorrência contra

\footnotetext{
${ }^{98}$ Que incluíam atividades como as de: "vidraceiros, consertadores de guarda-chuvas ou de colchões, padeiros, fornecedores de gelo, peixeiros, palmiteiros, cegos vassoureiros, entre tantos outros pequenos trabalhadores" (MORAES, José Geraldo Vinci de. Metrópole em sinfonia..., cit., p. 144). Sobre a abrangência do trabalho informal na cidade de São Paulo entre o fim do século XIX e as primeiras décadas do século XX, cf., ainda, MORAES, José Geraldo Vinci de. Sonoridades paulistanas: a música popular em São Paulo (fim do século XIX - início do século XX). Dissertação (Mestrado) - Pontifícia Universidade Católica, São Paulo, 1990; PINTO, Maria Inez Machado Borges. Cotidiano e sobrevivência: a vida do trabalhador pobre na cidade de São Paulo, 1890-1894. Tese (Doutorado) - Faculdade de Filosofia, Letras e Ciências Humanas, Universidade de São Paulo, São Paulo, 1984.

${ }^{99}$ Como atestam as propostas e carteirinhas de associados encontradas nas atas da associação entre 1928 e 1934 (ver tabela anexa e reproduções de carteiras de sócios). A observação também inclui as mulheres que, além de realizarem trabalho auxiliar nesses ofícios, como o "pespontar de calçados", tinham na costura sua principal atividade remunerada, pelo menos até a massiva entrada no trabalho industrial. É o que se vê no relato de Marianinna Ciambarela sobre sua experiência de emigrante da península itálica: "Costurei na máquina uma porção de anos para ajudar o Carmelo. Costurava calça para homem" (GOMES, Angela de Castro. A pequena Itália de Niterói: uma cidade, muitas famílias. In: de Janeiro. Rio de Janeiro: 7 Letras, 2000, p. 82). (Org.). Histórias de imigrantes e de imigração no Rio

${ }^{100}$ Quando uma parte considerável é deslocada para o trabalho fabril no próprio bairro da Barra Funda, a partir da chegada de quatro importantes indústrias que, segundo o veterano José Bertolozzi, "empregava[m] todo mundo" (entrevista com o Sr. José Carlos Bertolozzi, realizada em 24 de abril de 2010).

${ }^{101}$ Seus filhos Walmir e Wanderlei mantêm, ainda hoje, o endereço e o ofício do pai (entrevista com Arthur Tirone, realizada em 28 de agosto de 2011).
} 
outros marceneiros do bairro. ${ }^{102}$

Mesmo as atividades relacionadas aos serviços em geral parecem ter assumido características peculiares aos ofícios exercidos pelas famílias ligadas ao Anhanguera. A transmissão de saberes de pai para filho marca, por exemplo, a família Russo, envolvida há três gerações com o serviço de despachante iniciado por Roberto Russo, filho de Saverio. O mesmo acontece com os Tirone, e vale a pena acompanhar um pouco mais detalhadamente a trajetória profissional dessa família.

Nicola Tirone, o patriarca, começou a trabalhar como carroceiro desde que chegou à Barra Funda. ${ }^{103}$ Seu filho, Oswaldo, continuou o ofício do pai após passar um curto período como aprendiz na loja de ferragens Casa da Boia, na Rua Florêncio de Abreu. ${ }^{104}$ Anos depois, ele conseguiu habilitação junto ao governo do Estado para atuar como cocheiro e fazer “viagens ao moinho Manetti Gamba - hoje Moinho Santo Antonio - para buscar sacos de farinha, sempre entornando seu garrafão de vinho". ${ }^{105}$ A carroça foi substituída por um pequeno caminhão quando Oswaldo foi empregado, anos depois, pela empresa Brasilata, ${ }^{106}$ fato que alterou suas condições de trabalho, mas não sua movimentação pelo bairro. Curioso é que o veículo acabou assumindo vários usos dentro da comunidade, como o transporte de jogadores do Anhanguera pelos campos de futebol da cidade (figuras 4 e 5). ${ }^{107}$

\footnotetext{
${ }^{102}$ Pois uma espécie de licitação foi realizada a partir das propostas de marceneiros, as quais eram entregues em cartas e lidas em assembleia. Infelizmente não se sabe se os irmãos venceram também essa licitação, pois as atas seguintes não registram o desfecho desse processo (Atas da Associação Anhanguera, 17 mar. 1930).

${ }^{103}$ Um dos irmãos de Nicola, Roque Tirone, manteve durante anos uma gráfica na Barra Funda de cima.

${ }^{104}$ Entrevista com Arthur Tirone e "Grego", realizada em 25 de junho de 2011.

105 TIRONE, Arthur. Não quero redenção, quero a Argentina! Disponível em: <http://www.copa2014.turismo. gov.br/copa/copa_cabeca/detalhe/artigo_Artur_Tirone.html>. Acesso em: 19 jan. 2012.

${ }^{106}$ Empresa lembrada pelos veteranos com o nome por ela assumido em 1965, quando passou a abranger também a metalurgia. A empresa existia, no entanto, desde o final da década de 1940 e atuava no setor de plásticos. Histórico da empresa disponível em: 〈http://www.brasilata.com.br/pt/index.php〉. Acesso em: 8 ago. 2012.

${ }^{107}$ Entrevistas com Arthur Tirone, realizadas em 25 de junho e 28 de agosto de 2011. Cf. também: TIRONE, Arthur, op. cit.
} 


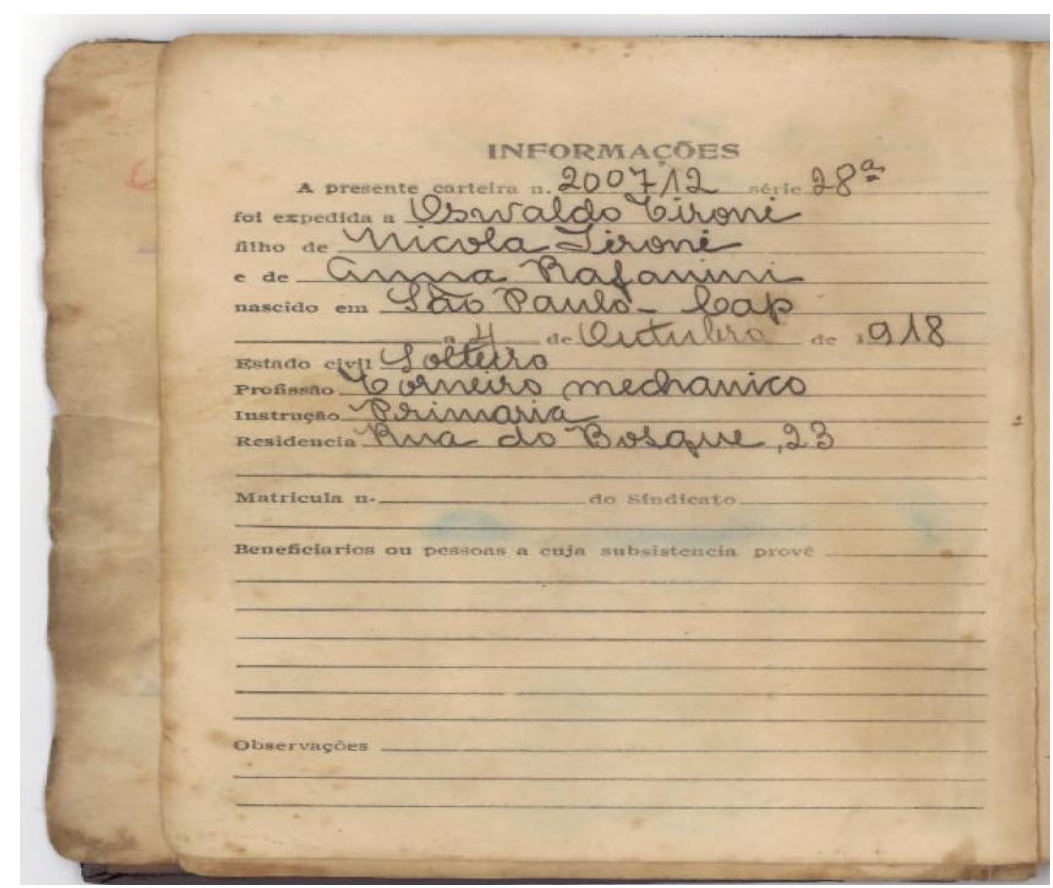

Figura 4 - Reprodução da carteira de trabalho de Oswaldo Tirone, p. 2, 1918. (Fonte: Acervo da família)

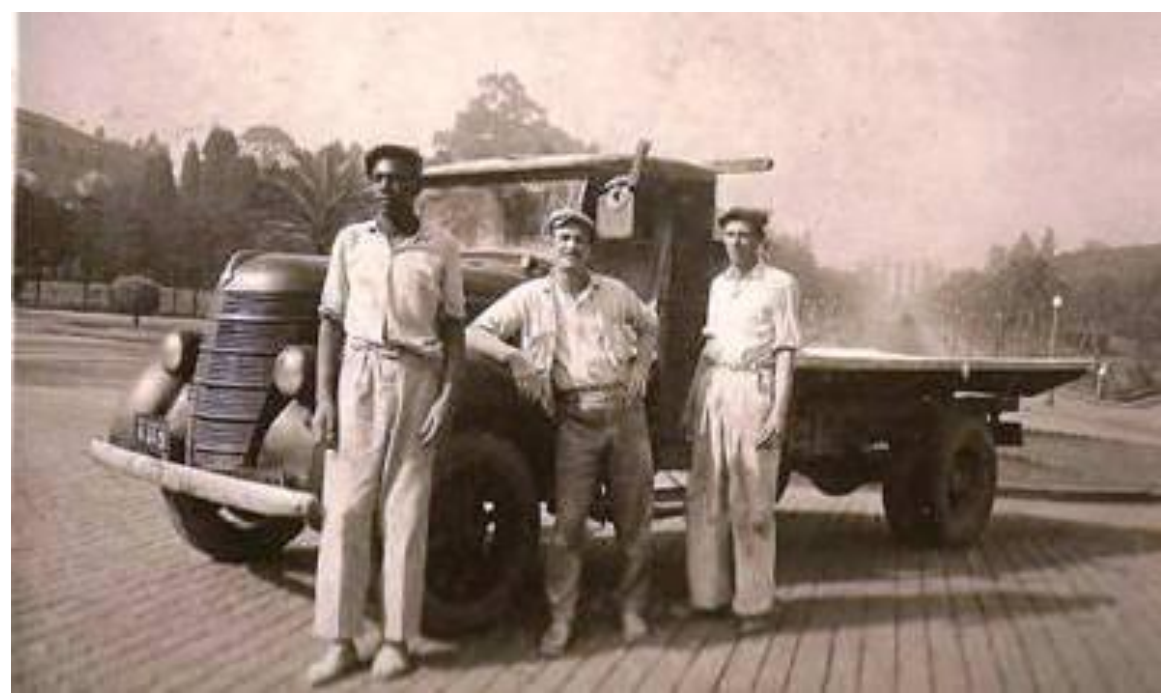

Figura 5 - Oswaldo Tirone, ao centro, com o veículo da empresa, anos 1950. (Fonte: Acervo da família)

Em geral aprendidos com parentes, amigos e em instituições religiosas ${ }^{108}$ ou de ajuda

${ }^{108}$ Como o Colégio Liceu Coração de Jesus - criado por padres italianos da ordem dos Salesianos -, que por volta de 1915 iniciou seus cursos profissionalizantes (Cf. PERELMUTTER, Daisy. Um Bom Retiro, cit., p. 6). 
mútua, ${ }^{109}$ esses trabalhos criavam estreitos laços sociais $\mathrm{e}^{110}$ revestiam-se de conteúdos ainda mais específicos no cotidiano das famílias ítalo-brasileiras, como se vê inclusive na forma como elas constituíam seus espaços de trabalho. Durante a primeira metade do século $\mathrm{XX}$, a casa era também o lugar de trabalho para boa parte da população imigrante e pobre, ${ }^{111}$ a despeito dos esforços empreendidos pelo poder público para ordenar a cidade a partir da separação entre espaço de trabalho e espaço de moradia. ${ }^{112}$ Assim, não por coincidência, grande parte dos pedreiros e mestres de obra da região eram peninsulares ou ítalobrasileiros, ${ }^{113}$ e as casas por eles concebidas reproduziam um padrão que previa espaço livre para a instalação de oficinas. Conhecido como ponta de chuva,

pois dizia-se que os capomastri utilizavam a ponta do inseparável guardachuva para demarcar a terra no início da construção, o modelo tinha por base as casas geminadas, com entrada lateral, tendo os cômodos enfileirados, no meio uma claraboia vazada, cozinha, quintal e porão. Havia [...] sempre um quintal onde eram instaladas as oficinas. ${ }^{114}$

\footnotetext{
${ }^{109}$ As associações de beneficência e de socorro mútuo eram correntes entre imigrantes desde o fim do século XIX. Atuando junto às comunidades étnicas, abrangiam desde a assistência médica até a inserção no mercado de trabalho. Sobre essa questão, cf. BIONDI, Luigi. Entre associações étnicas e de classe..., cit.

${ }^{110}$ A concentração de funções na fabricação e na comercialização dos produtos e a centralidade da situação de aprendizado vinculavam de maneira estreita mestres e aprendizes. Essa relação, bastante marcada por laços de dependência, está associada a vários elementos, entre eles: o custeio do aprendizado pelo aprendiz, "seja na forma de trabalho não remunerado, seja mediante pagamento direto, ou ainda como parte das relações informais de solidariedade, associadas ao parentesco" (MALATIAN apud REZENDE, Vinícius de. Da arte de saber fazer ao operário-boi? In: SIMPÓSIO NACIONAL DE HISTÓRIA, 26., 2011, São Paulo. Anais... São Paulo: ANPUH, 2011, p. 2). Sobre essa questão, cf. ainda THOMPSON, Edward Palmer. Costumes em comum: estudos sobre a cultura popular tradicional. São Paulo: Companhia das Letras, 1998, p. 280-304.

${ }^{111}$ Sem que tenham desaparecido por completo da Barra Funda depois desse período, caso da tapeçaria dos Olivieri, que, instalada na Rua Anhanguera, permanece em atividade nas imediações das residências da família.

${ }^{112} \mathrm{O}$ que seria conseguido, aos poucos, num processo que especializou o centro como zona terciária, gerando um "significativo esvaziamento populacional dos antigos bairros operários" (PAOLI, Maria Célia; DUARTE, Adriano. São Paulo no plural: espaço público e redes de sociabilidade. In: PORTA, Paula (Org.). História da cidade de São Paulo: a cidade na primeira metade do século XX, 1890-1954. São Paulo: Paz e Terra, 2004, v. 3, p. 69).

113 "Competentes nos diversos ofícios da construção civil, os peninsulares quase monopolizam o setor, compreendendo no começo do século cerca de três quartos dos pedreiros em atividade na cidade e a quase totalidade dos mestres-de-obras. Sem contar os arquitetos e escultores, que deixam, duravelmente, marcas visíveis nessa paisagem" (SCHPUN, Mônica Raisa. O cinema mudo em São Paulo..., cit., p. 73).

${ }^{114}$ SOARES, Dulce. Barra Funda: esquinas, fachadas e interiores. São Paulo: Imprensa Oficial, 1982. Aideli Urbani Brunelli et al. apontam, entretanto, dado um pouco diferente: "Eram casas com pequena frente, muita área de fundo, quartos enfileirados, entrada lateral, cozinha e banheiro nos fundos, e porão - que servia para guardar coisas que não cabiam nos quartos e, mais tarde, como moradia a ser locada. Algumas tinham oficinas, outras armazéns ou bares à frente" (Barra Funda, cit., p. 27).
} 
Esse padrão era parte de uma forma de vida fundada na transmissão não só do local de moradia e trabalho, mas também de conhecimentos, de ferramentas e, talvez, de uma cativa clientela para que as novas gerações pudessem continuar exercendo o ofício de seus pais e avós. A prática, que garantia a manutenção familiar de maneira endógena, parecia ser generalizada e representava um "papel estratégico na busca de ascensão social e de prestígio" entre os peninsulares, mesmo os mais abastados. ${ }^{115}$ Perpetuar o ofício na família representava, assim, um valor que estreitava ainda mais os elos no interior da comunidade imigrante, já alimentados pelo contato com a vizinhança "como fonte de ajuda mútua e de informações". 116

É nesse sentido que se pode compreender o valor da mensalidade cobrada pelo Anhanguera em 1928, provavelmente em acordo com os ganhos do segmento mais representativo do bairro: 3 mil réis, o que parecia razoável considerando-se que o valor médio do dia de trabalho de um operário à época era de 4 mil réis e que, “com isso, mal dava para comprar meio quilo de arroz ou macarrão, banha, açúcar e café", segundo Zuleika Alvim. ${ }^{117}$ O preço praticado no Anhanguera era o mesmo de outras associações esportivas e recreativas da região varzeana, como o Círculo Recreativo da Vila Buarque e o G.D.M. LusoBrasileiro. ${ }^{118}$ É interessante notar, entretanto, que tal valor equivalia a menos da metade da mensalidade cobrada, por exemplo, pelo Clube Atlético Paulistano, que cobrava, no mesmo período, “40\$000 de jóia e $10 \$ 000$ de mensalidade dos sócios efetivos apresentando, portanto, taxas de ingresso e de permanência ao seu quadro social restritivas para ampla camada da

\footnotetext{
${ }^{115}$ Como as famílias Crespi e Matarazzo, que rapidamente se integraram à elite paulista: "no que diz respeito aos filhos de imigrantes enriquecidos, as alianças matrimoniais representaram um elemento importante da fusão com a elite paulista. Os Crespi, os Weiszflogs, Siciliano, Matarazzo, Byington, Pereira Ignácio, Scarpa, etc. ligaramse desse modo à elite nacional, resultando tais alianças, quase sempre, em vantagens mútuas, no plano material e na obtenção de prestígio" (FAUSTO, Boris. Imigração..., cit., p. 35).

${ }^{116}$ Ibid., p. 41.

${ }^{117}$ ALVIM, Zuleika Maria. O Brasil italiano..., cit., p. 404.

118 Cf. SIQUEIRA, Uassyr de. Clubes recreativos: organização para o lazer. In: AZEVEDO, Elciene et al. (Orgs.). Trabalhadores na cidade: cotidiano e cultura no Rio de Janeiro e em São Paulo, séculos XIX e XX. Campinas: Ed. Unicamp, 2009, p. 272-305.
} 
população da capital". 119

A heterogeneidade socioeconômica dos associados do Anhanguera não impediu, contudo, que uma rica vida associativa se desenrolasse no clube. É o que indicam os relatos de antigos veteranos, como o do Sr. Walter Dias, ex-diretor social e ex-presidente da associação: "as coisas aqui giram em torno dos parentes. [...] Meu pai jogou aqui... meu pai conheceu minha mãe no baile [do Anhanguera]". ${ }^{120}$ Os laços familiares e os vínculos geracionais citados por Dias parecem representar alguns dos elementos responsáveis por certa diluição das diferenças socioeconômicas individuais no interior da associação. É o que também sugere Sandonato quando rememora a maneira como o clube funcionava: "era um trabalho feito em conjunto. Aqui ninguém pegava os louros da glória pra [si], aqui todo mundo trabalhava e isso era dividido entre nós". ${ }^{121}$ As lembranças de Dias e de Sandonato apontam para um convívio que "aplainava diferenças ao promover laços de congraçamento e de igualdade entre seus membros dentro do espaço associativo", ${ }^{122}$ embora não as dirimisse de todo, tampouco aos conflitos que também caracterizaram a vida no clube, como veremos em vários momentos de sua trajetória.

Esse convívio se dava em torno de diversas atividades, como descreve ainda Sandonato: "Não tinha só o futebol [no clube Anhanguera], tinha pingue-pongue, tinha baile, tinha festa de aniversário, festa do clube, festa de São João". ${ }^{123}$ Foi assim que os inúmeros associados, que se seguiram aos fundadores, primeiros diretores e presidente, engajaram-se

\footnotetext{
${ }^{119}$ SIQUEIRA, Uassyr de. Entre maxixes, peladas e palavras de ordem..., cit., p. 78.

${ }^{120}$ Entrevista com o Sr. Walter Dias, realizada em 22 de maio de 2009. Filho de Antenor Dias, diretor social do clube nos anos 1930, o Sr. Walter representa uma das gerações de associados que integrou o Anhanguera em meados dos anos 1940. Embora seja também difícil precisar as datas em que se associaram, todos os veteranos entrevistados faziam parte da vida do clube nesse período, quais sejam: Cirilo Magalhães, Sr. Pôncio, William Sandonato, José Bertolozzi, Nelson Manuel e Sr. Augusto Pereira Neto. Apenas o Sr. Salathiel Fernandes chegara um pouco antes, em 1937. Alguns deles ocuparam cargos da diretoria ou mesmo da presidência da associação, caso de William, Walter e Salathiel. Os demais foram jogadores de futebol.

${ }^{121}$ Entrevista com o Sr. William João Sandonato, realizada em 23 de maio de 2010.

${ }^{122}$ Tal como acontecia em outros gêneros de associações nos bairros populares de São Paulo: associações recreativas, de socorro mútuo ou sindicais (SIQUEIRA, Uassyr de. Entre maxixes, peladas e palavras de ordem..., cit., p .77).

${ }^{123}$ Entrevista com o Sr. William João Sandonato, realizada em 23 de maio de 2010.
} 
em tais eventos. Tal iniciativa era expressa por uma intensa circulação pela nova sede e, mais especialmente, pelo salão social, situação que parece ter estimulado os dirigentes do clube a fiscalizar as formas de uso desses espaços, de modo a organizá-lo. Além de restringir a circulação de associados na sede social e proibir o costume de parar e encostar nos corrimãos das escadas que lhe davam acesso, ${ }^{124}$ os diretores sociais passaram também a regular o acesso ao salão, controlando o uso das famílias ansiosas por promover eventos comemorativos como aniversários e casamentos.

Em março de 1930, por exemplo, foram estipulados os seguintes valores de aluguel do salão: "para sócios com mais de 3 meses [...] 80\$000, fundadores $50 \$ 000$ e particulares $100 \$ 000 " .{ }^{125}$ No mesmo ano, os proprietários do prédio não só foram dispensados desses valores, como lhes foi concedido o direito de usufruir do salão uma vez por ano. A proporção dos valores estabelecidos e o critério de isenção conforme a posição dos possíveis interessados revelam, uma vez mais, a estratificação social que vigorava no Anhanguera e a hierarquia estabelecida entre eles com base nesse critério. Revelam também que a maior ou menor possibilidade de acesso ao salão era definida a partir de uma escala crescente de valores em função do tipo de vínculo com o clube.

É nesse sentido que se pode compreender as poses e vestimentas presentes em uma das fotografias que integra os suportes de lembranças dos veteranos sobre as festas familiares realizadas na sede social do Anhanguera (figura 6).

\footnotetext{
${ }^{124}$ Em inúmeras atas são citados sucessivos encaminhamentos para diminuir a circulação de associados nesses espaços. Em junho de 1930, as atas registraram a necessidade de colocar: "um aviso na escada, prohibindo a permanência na mesma por qualquer pessoa" (Atas da Associação Atlética Anhanguera, 30 jun. 1930).

${ }^{125}$ Ibid., 3 mar. 1930.
} 


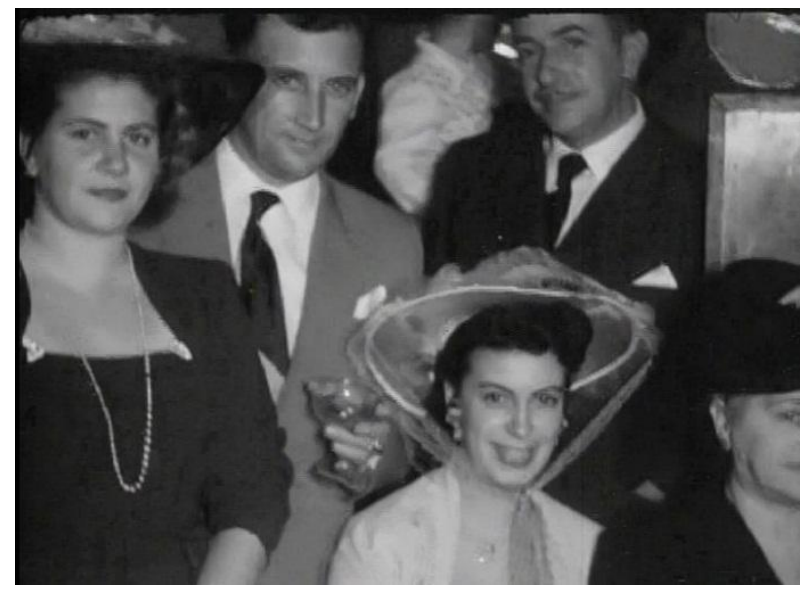

Figura 6 - Antônio Satriano (à direita) em festa de família realizada na associação esportiva, na década de 1930. (Fonte: Arquivo pessoal do Sr. Pedro Cardoso)

Os chapéus, penteados e demais adornos femininos, bem como as gravatas e os ternos masculinos dos convivas da família Satriano são índices da importância dessas festas para a comunidade constituída na Barra Funda e no clube, pois representavam não apenas um momento de encontro e comemoração com outras famílias, mas a ocasião para dar visibilidade a tais elementos que indicavam uma posição social alcançada. Assim, a dimensão de ostentação presente na imagem dos Satriano $^{126}$ só pode ser analisada em associação à construção de uma imagem em grande parte baseada na afirmação do valor do trabalho realizado no interior das famílias e de seus sinais diacríticos, como o acúmulo material por elas alcançado. Para Fausto, esses signos faziam parte de "uma convicção essencial. Eles se consideravam gente devotada ao trabalho, os verdadeiros construtores de uma cidade que ia se convertendo em metrópole". ${ }^{127}$ Assim, parece necessário considerar que, longe de ser um processo autorreferenciado, a construção de uma identidade pelos ítalo-brasileiros se deu em diálogo - nem sempre harmonioso - com os nascidos no país e também com outros

\footnotetext{
${ }^{126}$ Há que se fazer referência aos sobrenomes de famílias presentes no Anhanguera, como Satriano e Catapano. Após 1937, ampliou-se o controle sobre imigrantes e ítalo-brasileiros em todo o país. Uma das medidas para nacionalizar os estrangeiros foi a troca de $i$ por $o$ no final de nomes e sobrenomes (até 1937, as famílias eram Satriani e Catapani).

${ }^{127}$ FAUSTO, Boris. Imigração..., cit., p. 26. Sobre os usos das identidades sociais, cf. LEPETIT, Bernard. A história leva os atores a sério? In: . Por uma nova história urbana. São Paulo: Edusp, 2002, p. 239.
} 
imigrantes. Evitando preconceitos e, ao mesmo tempo, procurando afirmar-se na cidade de adoção, os peninsulares e seus descendentes encontraram no trabalho um signo com o qual se identificar que se tornaria a base para a negociação de sua identidade. Isso teve vários desdobramentos, inclusive no que se refere ao futebol.

Quanto às festas, não eram apenas particulares que as organizavam. A associação também as promoveu, mesmo que raramente. Em face delas, havia sempre grande mobilização. Em agosto de 1930, por exemplo, os diretores realizaram até mesmo reuniões extraordinárias para a organização de uma festa social e produziram listas em que se distribuíam tarefas especializadas: as ocuppações, a se concretizarem durante a festa com o auxílio dos associados: "guarda roupa (Geronymo Ferro, Antonio Vignola, A. Lescher); porta (Jacintho, Antenor); Escada (Catapani); salão (Antonio Victorino, Alvaro Santarelli); recepção (Eduardo Louzada); direcção geral (Miguel Vignola); corredor (João Cidro)". ${ }^{28}$

Além disso, "foi autorizada a compra de panno de bocca e encarregado da pintura o Sr. João Cidro [...] de cervejas e sandwichs para os músicos". ${ }^{129}$ Esse minucioso planejamento, que engajava associados, diretores e presidente nas atividades, evidencia a preocupação em corresponder às possíveis expectativas de associados. Ele também demonstra o interesse em seguir os códigos sociais que regiam esse tipo de evento, ${ }^{130}$ embora o clube não possuísse toda a estrutura para realizá-lo. Matheus Sabatini, por exemplo, foi "chamado [à assembleia] para informar se pode[ria] requisitar cadeiras da Antarctica"131 para a festa. Tal gênero de evento esteve mais associado às comemorações privativas de famílias ou mesmo da associação e tinha um caráter extraordinário e exclusivo.

\footnotetext{
${ }_{128}^{128}$ Atas da Associação Atlética Anhanguera, 11 ago. 1930.

129 Ibid.

${ }^{130}$ Aprendidos de variadas formas, seja pela circulação de informações sobre eventos dessa natureza por meio da imprensa, seja pela participação nas festas de associações vizinhas ao Anhanguera.

${ }^{131}$ Atas da Associação Atlética Anhanguera, 11 ago. 1930.
} 
Os eventos particulares perdiam em importância para as festividades de cunho religioso - como o carnaval e as festas juninas - e também para os bailes promovidos para arrecadar fundos para o clube, que representavam o momento de integração da comunidade Anhanguera junto a outros grupos do bairro. As festas de carnaval pareciam concentrar a atenção do clube e das demais sociedades do bairro. Elas se desenrolavam sob um padrão comum, em dois espaços distintos: o dos salões fechados e o de rua. Para Fausto, os primeiros "refletiam a participação dos grupos imigrantes, as diferenças de classe, o papel também recreativo dos principais clubes de futebol [...] bailes do Corinthians, no Cine Central, do Palestra Itália, no Parque Antártica, da Portuguesa de Esportes no Parque Pedro II". ${ }^{132}$ Tratava-se de algo reconhecido e explorado pela imprensa, que desde os primeiros anos do Anhanguera publicava notas como a seguinte:

Iniciando os festejos comemorativos do reinado do Momo, o clube Anhanguera promoverá, no próximo dia 04 de fevereiro, um baile a fantasia, familiar, o qual terá lugar em sua sede [...] o Anhanguera não está poupando esforços, tendo já organizado uma quermesse e outras atrações. ${ }^{133}$

$\mathrm{O}$ excerto indica o interesse da cidade e não apenas do bairro em eventos dessa natureza. O clube integrava as comemorações de rua a partir de eventos promovidos em conjunto com outras associações de bairro e com os cordões carnavalescos. A guerra de confetes era o principal deles: "nós fazíamos guerra de confete. A Rua Anhanguera com a Rua do Bosque ficava cheia de confete. O Camisa [Verde, cordão carnavalesco] às vezes passava lá". ${ }^{134}$ Durante a passagem dos cordões, as associações comerciais, recreativas ou esportivas ofereciam-lhes presentes. O momento era bastante valorizado, pois correspondia a uma das formas de concorrer para o brilho do bairro, ao mesmo tempo em que colocava em

\footnotetext{
${ }^{132}$ FAUSTO, Boris. $O$ crime do restaurante chinês..., cit., p. 64-65.

${ }^{133}$ Folha da Manhã, 22 jan. 1933, p. 4.

${ }^{134}$ Entrevista com o Sr. Walter Dias, realizada em 22 de maio de 2009.
} 
destaque as possibilidades das sociedades ${ }^{135}$ - entrevistas pelo valor de suas ofertas em comparação com as demais -, o que é notável desde os primeiros anos do clube. Como exemplo, há o registro em ata de assembleia de 1934 sobre a compra desses presentes: "para os cordões carnavalescos Flor da Mocidade e Camisa Verde ficou resolvido offerecer uma taça a cada um, sendo que a compra das ditas taças deverá ser feita por meio de rateio". ${ }^{136} \mathrm{O}$ carnaval era o momento de maior interação coletiva entre a comunidade negra e a comunidade imigrante da Barra Funda, embora seus representantes individuais também interagissem em outras situações, como as relacionadas ao futebol.

Já no que se refere aos bailes, pode-se dizer que eram eventos ainda mais comuns do que tais festividades, sendo também os responsáveis pelos encontros da comunidade do bairro de maneira menos ritualizada. Eram parte importante da receita do clube, justamente graças à abertura para não associados. O valor dos convites e a presença de músicos atraíam a vizinhança, em geral já bastante afeita àqueles eventos. Além do Anhanguera, outras associações da região, como o Clube Royal, ${ }^{137}$ dedicavam-se apenas a promovê-los.

Em vários momentos, os bailes tornavam-se parte coadjuvante de outros eventos sociais, como se nota em uma das atas da Associação Anhanguera, de julho de 1933: "ficou marcado para a data de 22 do corrente um festival dramático-dançante sendo que o mesmo constará de uma surpresa (anedocta) e uma comédia. A seguir, um pomposo baile familiar". ${ }^{138}$ O baile parecia representar um apelo extra à participação no festival dramático. Note-se que, além de pomposo, ele era sobretudo familiar, o que reafirma seu caráter aglutinador e articulador ao promover o encontro de mulheres e homens, jovens e adultos. Por essa razão,

\footnotetext{
${ }^{135}$ Sobretudo quando se leva em conta que a passagem dos cordões era a principal forma de vivenciar o carnaval de rua entre os varzeanos, uma vez que os corsos e outros tipos de desfiles eram domínio dos segmentos mais abastados da população (Cf. FAUSTO, Boris. O crime do restaurante chinês..., cit.).

${ }^{136}$ Atas da Associação Atlética Anhanguera, 29 jan. 1934.

${ }_{137}$ Associação recreativa fundada por negros na Barra Funda de cima nos primeiros anos do século XX.

${ }^{138}$ Atas da Associação Atlética Anhanguera, 4 jul. 1933. A historiadora Mônica Schpun fala da importância do teatro e do cinema mudo entre ítalo-brasileiros desde fins do século XIX até as primeiras décadas do século XX (O cinema mudo em São Paulo..., cit.).
} 
tais ocasiões eram também as mais adequadas para a apresentação dos filhos casadoiros pelas famílias, o que parecia ser um expediente tão comum quanto eficaz. A circunstância não deixa de sinalizar como se mantinham os vínculos entre os ítalo-brasileiros no bairro.

É em meio a esse universo que se pode compreender o tipo de participação das mulheres em tais eventos coletivos e sociais organizados pela associação: elas eram integradas desde o momento da organização, trabalhando na venda e na entrega de convites ou na confecção de importantes artefatos à associação, como se nota na seguinte situação: “a nossa admiradora, Srta. Nêna Tezzi, como prova de symphatia a nossa associação, pede uma autorização por escripto aos directores, a fim de vir buscar a nossa bandeira para executar outra idêntica". ${ }^{139}$ O batizado de novas bandeiras era um importante evento festivo que envolvia associados dos clubes e representantes de entidades a eles simpáticas que compareciam levando flores, entre outros presentes.

A participação feminina nesse gênero de atividade era estimulada pelos dirigentes do clube, que tinham o costume de retribuir presentes ou dedicação com reconhecimento público, conforme também registrado nas atas da associação logo após o pedido da Srta. Nêna: "o presidente faz um voto de agradecimento às senhoritas admiradoras". ${ }^{140}$ Não se pode deixar de notar a formalidade desse mútuo tratamento. Ao chamar de admiradora a moça solicitante, ao classificar seu trabalho como prova de simpatia à associação e, mais importante, ao se comunicar com ela por escrito, o presidente indicava também qual era o comportamento ali instituído para as mulheres, ainda que algumas delas fizessem parte do seleto grupo que constava nas propostas da associação, ${ }^{141}$ caso da própria Srta. Nêna.

\footnotetext{
${ }^{139}$ Atas da Associação Atlética Anhanguera, 9 set. 1929.

${ }_{140}^{14}$ Atas da Associação Atlética Anhanguera, 16 set. 1929.

${ }^{141}$ As propostas de novos associados eram realizadas nas assembleias semanais e vinham acompanhadas de um propositor, um padrinho que seria o responsável pelo novo associado, tema ao qual voltaremos no segundo capítulo.
} 
Integradas ao clube como parte da família do associado, o que as dispensava de figurar individualmente como sócias, Nêna e algumas poucas mulheres foram diretamente propostas e aceitas como associadas em 1928 (figura 7).

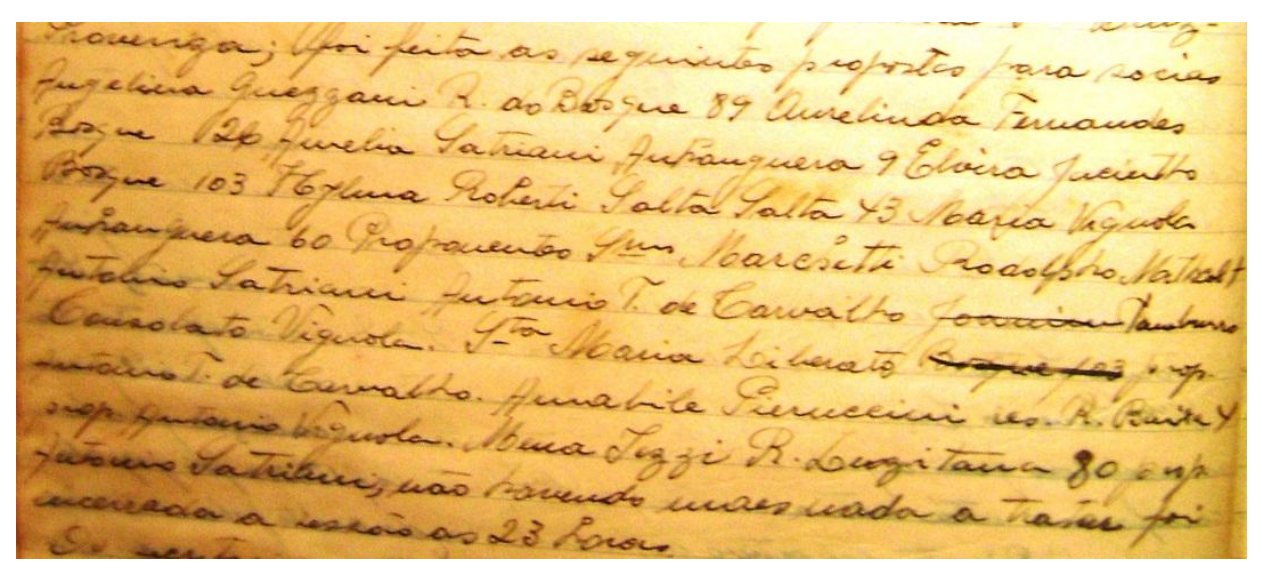

Figura 7 - Reprodução de ata: Angelina Guezzani, Rua do Bosque, 89; Aurelinda Fernandes, Rua do Bosque, 26; Amelia Satriani, Rua Anhanguera, 9; Elvira Jacintho, Rua Bosque, 103; Helena Roberti, Rua Salta-Salta, 43; Maria Vignola, Rua Anhanguera, 60. Proponentes: Srs. Marchetti; Rodolpho M.; Antonio Satriani; Antonio T. de Carvalho Lambrusco; Consolato Vignola; Srta. Maria Liberato proposta por Antonio T. de Carvalho Lambrusco; Amabile Pieruccini proposta por Antonio Vignola. Nenna Tezzi, Rua Luzitânia, 80, proposta por Antonio Sabatini. (Fonte: Atas da Associação Atlética Anhanguera, 26 nov. 1928)

Os sobrenomes das novas associadas não deixam dúvidas sobre seu parentesco com importantes sócios do clube, o que talvez explique a excepcionalidade da situação. De todo modo, o fato não alterava o que a entidade a elas destinada. Salvo engano, não foram encontrados casos de participação feminina nos esportes promovidos pelo Anhanguera; diferentemente do que se passava no Clube Atlético Paulistano, que mantinha modalidades atléticas em que a participação feminina era estimulada, como o tênis e a natação. ${ }^{142}$

A forma como as mulheres foram integradas à vida associativa do Anhanguera ajuda a compreender por que a presença de damas solteiras nos bailes do Anhanguera nunca foi bem vista, à exceção, evidentemente, das jovens casadoiras acompanhadas de seus pais. A preocupação com o comportamento feminino ocupava boa parte das assembleias que

${ }^{142}$ Cf. SCHPUN, Mônica Raisa. Beleza em jogo..., cit. 
sucediam aos bailes realizados aos sábados e domingos; diretoria e presidência buscavam regras e sanções para reduzir condutas - masculinas e femininas - consideradas inadequadas ao bom andamento desses eventos sociais. Uma delas foi relatada pelos diretores sociais em novembro de 1929: um associado tomara a iniciativa de retirar uma mulher suspeita do baile e, em seguida, ainda teria dito que "as moças que frequenta[vam] a sociedade eram piores do que a referida mulher". ${ }^{143}$ Diante do evento, "o senhor presidente achou que seria útil suspender o dito senhor por 30 dias". ${ }^{144}$ É desse tipo de situação que sobrevinha a centralidade da figura do mestre-sala no clube. Espécie de articulador e regulador de comportamentos dos convivas em festas ou bailes, era ele quem acabava por centralizar tensões como a descrita.

As atas referentes ao período em que o clube realizou seus primeiros bailes são ricas em registros que expõem os conflitos protagonizados por diferentes mestres-salas, e a maior parte dessas ocorrências terminava com a desistência da função pelos associados, gerando uma grande rotatividade de pessoas no cargo. $\mathrm{O}$ desrespeito às damas era o conflito mais frequente. Em uma das assembleias ao final do ano de 1929, por exemplo, o então presidente “Antonio Vignola pediu a palavra dizendo que Antonio Victorino, como mestre-sala, não se portou segundo o regulamento interno". ${ }^{145}$ Por essa razão, foi deliberado "supendel-o [por] 30 dias e destituil-o do cargo". ${ }^{146}$ No ano seguinte, registrou-se o caso do Sr. Seraphin Santarelli, “censurado por ter infringido os estatutos, pois achava-se conversando com damas". ${ }^{147}$ Tanto Victorino quanto Santarelli, na condição de mestres-salas do clube, eram responsáveis por indicar a possibilidade de dançar ou não com as damas, além de regular o devido contato com elas durante os bailes. Como se vê, a tarefa parecia representar dificuldades não apenas para

\footnotetext{
${ }^{143}$ Atas da Associação Anhanguera, 5 nov. 1928.

144 Ibid.

${ }^{145}$ Ibid., 16 dez. 1929.

${ }_{146}^{14}$ Atas da Associação Anhanguera, 16 dez. 1929.

${ }^{147}$ Ibid., 4 ago. 1930.
} 
os simples convivas, mas também para os mestres-salas presentes nos bailes, algo extensível inclusive à própria diretoria do clube, haja vista a pluralidade de critérios em ação nas penalidades aplicadas a cada um.

Em verdade, essa dificuldade extrapolava a situação específica do clube. A cidade de São Paulo vivia as ambiguidades decorrentes da progressiva adoção de novos costumes pelas mulheres - de maior individualização e integração com a cidade possibilitadas pelo trabalho , embora continuassem a carregar consigo a imagem social da família. Segundo Schpun:

diante dessa nova dinâmica, códigos sexuados despontam, atravessando o processo de urbanização paulistano, acrescentando-lhe assimetrias consideráveis. Trata-se então - e antes de mais nada - de gerir a presença física de homens e mulheres. [...] em relação às mulheres, o aparecer em público demanda um trabalho constante, cotidiano e minucioso sobre a aparência; trabalho prévio à sua entrada, extremamente ritualizada, no espaço da cidade. ${ }^{148}$

É nesse sentido que se pode compreender a centralidade das atividades sociais no cotidiano do clube, bem como o tipo de participação, sob tantas regras específicas, previsto para as mulheres durante os anos 1930. Os valores associados à família eram elementos caros à identidade e à dinâmica do Anhanguera, algo comum entre as mais diferentes entidades associativas à época. Não se pode esquecer da força gregária de tais valores na comunidade imigrante e nem de sua proximidade com os valores do Estado Varguista.

Ao figurarem como representantes da família, as mulheres e sua sociabilidade eram fonte de preocupação e controle. Assim, parecia necessário "que se radicalizasse o cerco [...] diante da ameaça da destruição dos valores morais tradicionais trazida pelo feminismo, com

\footnotetext{
${ }^{148}$ SCHPUN, Mônica R. O cinema mudo em São Paulo..., cit., p. 78. Em Gênero e artefato, a historiadora Vânia Carneiro de Carvalho revela a forma como a elite paulistana, bem como a classe média em formação criam, nas primeiras décadas do século $\mathrm{XX}$, novos mecanismos para expressar seus valores, bens e modos de vida. $\mathrm{O}$ sistema doméstico vai aos poucos ocupando essa função e as mulheres figuravam como elementos centrais nessa dinâmica (Gênero e artefato: o sistema doméstico na perspectiva da cultura material, São Paulo, 1879-1920. São Paulo: Edusp; Fapesp, 2008).
} 
suas reivindicações de direitos para as mulheres", ${ }^{149}$ sobretudo se isso prejudicasse a base de valores de um clube como o Anhanguera.

Ao mesmo tempo, uma sociabilidade propriamente masculina se desenrolava a partir de outros preceitos, muito menos restritivos, em espaços e momentos diferenciados. Fundamentalmente ancorada no convívio entre associados, ela se iniciava em momentos complementares às partidas de futebol - durante a semana, após o horário de trabalho - e se estendia final de semana afora.

\subsection{A passatella, os bares e os homens}

Nas sextas-feiras à noite, ${ }^{150}$ a diretoria esportiva do Anhanguera fazia a escalação dos times de futebol de $1^{\circ}$ e $2^{\circ}$ quadros e a "pendurava no mural ao lado do painel de fotografias dos associados". ${ }^{151} \mathrm{O}$ costume reunia os sócio-jogadores na sede social para "saber quem ia jogar no domingo contra o adversário", rememora William Sandonato, expresidente da associação. "Antes as pessoas não ficavam embaixo. [...] o bar ficava na sede [segundo piso, primeiro andar] e todo mundo ficava na sede [...] jogando baralho, truco e aqueles jogos italianos". ${ }^{152}$ Os jogos italianos aos quais Sandonato se refere são a passatella e a morra, que ocupam lugar de destaque nas lembranças dos veteranos entrevistados, embora a boccia, a tômbola e outros jogos de salão também figurem como passatempos importantes na rotina no clube.

Em geral classificados como jogos de estratégia ou de azar, a passatella e a morra chegaram ao Brasil com os primeiros imigrantes, ao mesmo tempo em que sofriam uma série de restrições em toda a península itálica até serem definitivamente proibidas na década de

\footnotetext{
${ }^{149}$ RAGO, Margareth. A invenção do cotidiano..., cit., p. 402.

${ }^{150}$ A título de comparação, as atividades relacionadas ao futebol no Clube Atlético Paulistano aconteciam à tarde, mesmo em dias úteis (Cf. NEGREIROS, Plinio José L. de Campos. Resistência e rendição..., cit., p. 44).

${ }^{151}$ Entrevista com o Sr. William João Sandonato, realizada em 23 de maio de 2010.

152 Ibid.
} 
1920, principalmente na região centro-sul, onde ainda eram jogadas em tavernas. ${ }^{153}$ Os jogos possuíam base comum e não raramente apareciam combinados:

A passatella é um jogo que se joga em tavernas, em que um padrone $e^{154}$ e um sottopadrone (ou simplesmente sotto) - distribuem um vinho comprado coletivamente aos bebedores da companhia, a todos, exceto um que fica de "boca seca", sem beber nada. O padrone, que pode tomar vinho à vontade, é escolhido com o jogo da morra, um jogo de baralho [...] na realidade não é possível falar de passatella em termos absolutos, mas de diversas passatella de vários territórios do centro-sul da Itália que, no curso dos séculos, deram origem a jogos com características diferentes. ${ }^{155}$

Todos os participantes deveriam fazer parte do rateio da compra da bebida em questão: na Itália, o vinho; em São Paulo, o conhaque e, principalmente, a cerveja. Os veteranos do Anhanguera rememoram constantemente a experiência de jogar a passatella, destacando elementos que merecem atenção:

A Passatella [...] também conhecida como Patrão e solto (sic), era um jogo pra todo mundo. E sempre tem um que cai e bebe, cai e bebe, cai e bebe. Tinha o patrão e o solto. O solto... se o patrão dava [?] pra ele, ele era chamado de coelho (e iam até pegar feixe de capim pra dar para o cara). E não podiam dar cerveja pra ele. ${ }^{156}$

O relato de Sandonato é muito próximo ao apresentado por Walter Dias:

[...] é uma brincadeira pra beber. Você brinca com 10 pessoas. E então colocavam os dedos [...], por exemplo, ele é meu amigo, mas não vai beber de jeito nenhum. Eu bebo e dou pra quem eu quero. A gente escolhia os que iam e os que não iam beber. [...] Tinha cara que pagava 30 cervejas, mas não tinha direito a beber nenhuma e nem tinha o direito de levantar da roda. [...] era uma brincadeira sadia. ${ }^{157}$

153 VENDITTI, Antonio. Un'istituzione romana: il gioco della Passatella. Disponível em: <http://www. specchioromano.it/fondamentali/Lespigolature/2003/GENNAIO/Un\%E2\%80\%99istituzione\%20romana\%20-\% 20\%20il\%20gioco\%20della\%20Passatella.htm>. Acesso em: 16 abr. 2012.

${ }^{154}$ Literalmente dono.

${ }^{155}$ DI RISIO, Donato. Il Manuale della Passatella. Roma: Prospettiva Editrice, 2003, tradução nossa.

${ }^{156}$ Entrevista com o Sr. William João Sandonato, realizada em 23 de maio de 2010.

${ }^{157}$ Entrevista com o Sr. Walter Dias, realizada em 22 de maio de 2010. 
Tais relatos têm em comum não a precisa descrição de como se desenvolvia o jogo - o de Dias indica uma combinação entre a passatella e a morra, por exemplo ${ }^{158}$-, mas a referência aos lugares assumidos pelos participantes e às condições de permanência no grupo na situação de jogo; remetem à vivência compartilhada e mediada por uma prática que promovia a renovação do vínculo entre os participantes: antes ninguém ficava em baixo, era um jogo pra todo mundo, uma brincadeira sadia. A reciprocidade e a alternância de posições a cada rodada parecem ser as bases sobre as quais o jogo se desenvolvia. ${ }^{159}$ Esses elementos se tornam mais evidentes quando Dias complementa seu relato contando uma das peripécias de Ministrinho, um diretor do Anhanguera que "era baixinho" e um grande jogador de passatella: "Cada vez que ganhava, Ministrinho subia na escada e virava de cabeça para baixo para beber [o copo]. E os outros perguntavam: 'mas como?'”. 160

Ecléa Bosi recolhe depoimento em que a descrição do jogo Patrão e sotto é um pouco mais precisa:

O jogo era assim: uma turma de dez, quinze pessoas se reunia, cada uma estendia alguns dedos, somavam os dedos e escolhiam o patrão, a partir de um certo número. Por exemplo, 32, contavam e aquele que o toque indicava dizia: 'Eu sou o patrão!' Outro toque escolhia o sotto: 'Temos o patrão e sotto'. Mandavam vir a bebida; naquele tempo importavam vinho da Itália nas cidades ou bebia-se cerveja, mas nas fazendas era pinga mesmo, dos alambiques de lá. O garrafão era dividido em garrafas e o patrão era o dono daquilo; podia beber tudo sem dar satisfação a ninguém porque ele era o patrão. Se ele quisesse podia dividir com seus apaniguados mas precisava da anuência do sotto que era secretário dele. O sotto também tinha seus apaniguados: 'Se o patrão quer dar bebida praquele, tem que dar para os meus também'. E se ajustava assim. Se o patrão negava dar para quem o sotto queria, bebia toda a pinga e acabou-se. Quando começava o porre, não,

\footnotetext{
${ }^{158}$ A escolha do patrão é índice da passatella, mas iniciar o jogo mostrando os dedos indica que a morra estava ali incorporada. Tal combinação parecia ser corrente, como vimos.

159 Assim como os jogos de tômbola e boccia, a passatella e a morra são compreendidas como práticas não modernas, por se basearem em elementos construídos de maneira endógena aos grupos praticantes a partir da proximidade e da reciprocidade de seus representantes, e não em critérios universais como a isonomia, o que acontece nos jogos e esportes modernos que dependem da afirmação da condição de igualdade para se iniciarem. Nesses últimos, é apenas no transcorrer do jogo que as diferenças em termos de técnica ou eficácia aparecem, determinando a desigualdade entre os oponentes e justificando o resultado final. Cf. HUIZINGA, Johan. Homo ludens: o jogo como elemento da cultura. São Paulo: Perspectiva, 2000; CALLOIS, Roger. Les jeux et les hommes. Paris: Gallimard, 1985.

${ }^{160}$ Entrevista com o Sr. Walter Dias, realizada em 22 de maio de 2010.
} 
o jogo, o patrão e o sotto enchiam dois copos, batiam os copos um no outro e bebiam. Aí iam cuidar do resto; segundo o que eles decidiam, a pinga era distribuída ou não. O patrão podia tomá-la toda, se ele quisesse, não daria nem para o sotto. Geralmente havia sempre um que ficava all'urmo, era um termo italiano que queria dizer que nem uma gota dava praquele, era castigado entre os compadres todos que jogavam, e não podia reclamar porque jogo é jogo. ${ }^{161}$

Jogos como a passatella, a morra e mesmo outros jogos de baralho foram muito praticados dentro de associações esportivas como o Anhanguera, ainda que elas carregassem a "preocupação em funcionar dentro dos limites do legalmente permitido", ${ }^{162}$ procurando "realizar somente atividades lícitas e regulamentadas pelas leis". ${ }^{163}$ Em verdade, os associados buscavam,

ao menos aos olhos da polícia, desvencilhar-se de práticas condenadas e perseguidas - como os jogos ilegais e os bailes populares que ocorriam em botequins e cortiços da cidade, muitas vezes sem a permissão policial. Buscavam, dessa forma, facilitar a obtenção de alvará para seu funcionamento e maior liberdade de atuação diante da fiscalização das autoridades policiais. No entanto, nem todas as agremiações que solicitavam autorização policial sabiam quais jogos de fato eram permitidos. ${ }^{164}$

É interessante notar, ainda, que tais jogos são reportados apenas pela memória coletiva dos veteranos e em situações bastante específicas, como o momento de escalação do time de futebol às sextas-feiras. Nem mesmo as atas, cujos registros se caracterizam por constante referência aos conflitos entre associados, citam essas partidas, o que talvez se deva justamente às preocupações com as leis que regulavam tais práticas.

De todo modo, esses jogos continuaram a ser praticados até pelo menos os anos 1960 , sendo elementos centrais da sociabilidade dos associados do Anhanguera. Vinculados às bebidas e à companhia de colegas e amigos - pois raramente desconhecidos tomavam parte

\footnotetext{
${ }^{161}$ BOSI, Ecléa. Memória e sociedade... cit., p. 223.

162 SIQUEIRA, Uassyr de. Clubes recreativos..., cit., p. 280. A preocupação do poder público com tal sociabilidade traduzia-se numa defesa de alternativas "de recreação para os trabalhadores, como jardins e clubes esportivos, tendo em vista retirá-los dos bares, botequins, cabarés e associações políticas" (RAGO, Margareth. A invenção do cotidiano na metrópole..., cit., p. 418).

${ }^{163}$ Ibid.

${ }^{164}$ Ibid.
} 
dessas atividades -, eles compunham um universo vinculado ao cotidiano dos bares, como rememora o Sr. Pedro Cardoso:

era uma festa, conversar, rir, beber e comer o tempo todo. Eu via na Rua Anhanguera, esquina da Rua do Bosque que o ponto da Morra era sempre ali no bar do Aires, embaixo do Clube Anhanguera. Eram vinte ou mais homens entre napolitanos, calabreses ou milaneses que iam disputar no grito a bebida e a glória de ser Patrone. Era ele que falava quem bebia ou não. O Aires até dizia que quando tinha Morra quatro engradados de cerveja iam embora. Pegavam uma mesinha do bar e colocavam na calçada, ordem do proprietário portuga. Aí a Morra corria solta... começava no fim de tarde e nisso iam horas. Juro que se ouvia à distância de um quarteirão [...] uma algazarra, mas era uma algazarra de gente feliz. ${ }^{165}$

A sede social do clube era localizada na Rua Anhanguera, onde havia a parada final de uma linha de bondes com descida obrigatória de passageiros. ${ }^{166} \mathrm{O}$ volume de pessoas, sobretudo homens, voltando para casa após a jornada de trabalho explica a concentração de bares no local, também "conhecido como 'fim da linha' ou 'balão do bonde”,, onde se reuniam os "famosos bêbados do bairro". ${ }^{167}$ Havia "dez bares da porteira até aqui", conta Sandonato ao indicar com as mãos o trecho entre a Rua Anhanguera e as porteiras da ferrovia Sorocabana (mapa 2). Três deles tornaram-se conhecidos pelas alcunhas Fecha nunca, Nunca fecha e Sempre aberto, pois se revezavam em feriados e datas comemorativas para atender a clientela do bairro, de modo que ao menos um deles permanecia funcionando (figura 8). ${ }^{168}$

\footnotetext{
${ }^{165}$ Entrevista com o Sr. Pedro Cardoso, realizada em 13 de setembro de 2012.

${ }^{166}$ Desde 1902, a linha ligava a Barra Funda ao Largo São Bento, no centro da cidade.

${ }^{167}$ Segundo depoimento do senhor Angelo Catapano, antigo morador do bairro e associado do Anhanguera (Cf. BRUNELLI, Aideli S. Urbani et al. Barra Funda, cit., p. 20).

${ }^{168}$ Os bares são rememorados também por sua longevidade, sendo que o último deles veio a ser fechado apenas recentemente (entrevista com o Sr. William João Sandonato, realizada em 23 de maio de 2010).
} 


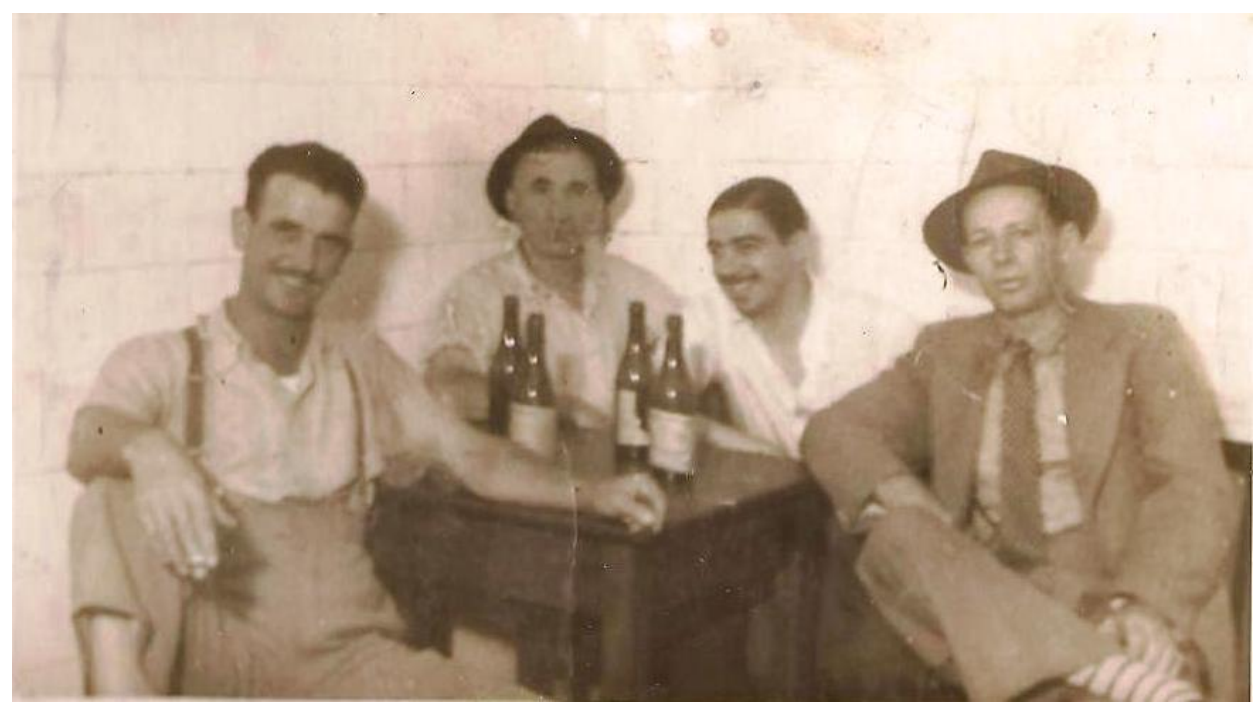

Figura 8 - Oswaldo Tirone, à esquerda, com amigos em um dos bares da Rua Anhanguera na década de 1940. (Fonte: Acervo da família)

Além dos bares, as vendas localizadas na região também serviam de ponto de encontro no bairro. Segundo o veterano William Sandonato, uma delas, chamada Gianotti, foi responsável pelo surgimento de um famoso bloco de carnaval nos idos dos anos 1940:

Eu era moleque, nem ia no Anhanguera ainda [e] pra cá tinha um bloco que inventaram: "Morro de fome, mas não trabalho". Todo ano morria um. Todo ano saía uma encrenca [...] eles eram todos pinguços [...] era a turma que ficava no bar todo dia... Não trabalhavam... Eles iam pra cidade e voltava a notícia de que tinha acabado um... Então colocaram "Morro de fome, mas não trabalho". ${ }^{169}$

O lema ironiza os valores do trabalho defendidos desde a chegada das primeiras gerações de imigrantes à região, o que coloca questões sobre a percepção de ítalo-brasileiros e outros suburbanos perante sua condição no contexto de transformações da cidade a partir dos anos 1930. Ao mesmo tempo, ele revela a centralidade do contratempo do trabalho vivido nos bares, em que

a vida boêmia passa a exercer enorme fascínio como lugar de evasão, do diletantismo, dos prazeres, da possibilidade de escapar à normatividade da

${ }^{169}$ Entrevista com Cirilo Magalhães, realizada em 12 de fevereiro de 2011. 
vida cotidiana que progressivamente se instaurava [...] o público masculino era o maior beneficiado com as transformações com a geografia do prazer. ${ }^{170}$

Nesse sentido, não se pode deixar de notar que tal sociabilidade masculina passava também pelos significados compartilhados em relação ao mundo do trabalho. Assim, desde o início, o clube criou momentos de partilha - ainda que nem sempre de maneira harmoniosa de tempos, espaços, condutas e valores em torno de atividades que ofereciam "nome e visibilidade social" ${ }^{\prime 71}$ a cada associado, em diálogo com os perfis sociais desejados pela comunidade. Essa rica vida associativa caracterizava, pois, a dinâmica cotidiana da Associação Anhanguera, ${ }^{172}$ atribuindo contornos bastante singulares ao modo como o futebol foi vivido no clube.

${ }^{170}$ RAGO, Margareth. A invenção do cotidiano..., cit., p. 397.

${ }^{171}$ SEABRA, Odette Carvalho de Lima. Urbanização e fragmentação..., cit., p. 393.

${ }^{172}$ Uassyr de Siqueira e Mônica Schpun exploram a criação desses universos em meios populares e de elite, respectivamente (SIQUEIRA, Uassyr de. Clubes recreativos..., cit., p. 281; SCHPUN, Mônica Raisa. Beleza em jogo..., cit., 1999). 


\section{O futebol no Anhanguera: entre ajustes e conflitos de interesses}

\subsection{Circulação e estabilidade: os primeiros campos de futebol do Anhanguera}

Vimos como a Associação Atlética Anhanguera estabeleceu sua sede social e com ela deu início a experiência muito similar às das associações recreativas, sindicais ou de socorro mútuo nascidas na região da Barra Funda e do Bom Retiro. Essa rica vida associativa criada no clube se organizava em torno de um interesse diferente e novo, tido como ícone de modernidade: o futebol. A novidade acrescentava questões ao já complexo cotidiano daqueles varzeanos ítalo-brasileiros, pois, além de promover atividades e eventos que contemplavam as famílias, o Anhanguera tomava parte da nova "sensibilidade que se [ia] definindo" em São Paulo e que tinha na ação corporal uma de suas principais significações e no futebol um de seus principais ícones. Tratava-se de tomar parte na dinâmica de um esporte que figurava como a base de um amplo diálogo na cidade.

Para tanto, era preciso que o clube se organizasse para manter times de futebol - que atendessem os associados conforme seu desempenho ${ }^{2}$ e faixa etária - e a rede responsável pelos jogos amistosos, campeonatos e festivais varzeanos. Por último e mais importante: era necessário dispor de campos de futebol para, efetivamente, tomar parte dessa dinâmica. Sem campo de futebol, próprio ou alugado, os clubes não se mantinham. Essa necessidade mergulhou o clube Anhanguera nas amplas disputas pelo espaço urbano que caracterizaram os primeiros anos do século XX em São Paulo. É o que se nota em suas tentativas de estabelecer uma sede esportiva permanente.

\footnotetext{
${ }^{1}$ SEVCENKO, Nicolau. Orfeu extático na metrópole..., cit., p. 32.

${ }^{2}$ Assim classificados: $1^{\circ}$ quadro, formado pelos mais habilidosos; $2^{\circ}$ quadro, juvenil, infantil e extra. Adiante, já nos anos 1940, surge também o time de veteranos.
} 
Ao contrário do que se passou em relação à sua sede social, rapidamente estabelecida - e de maneira definitiva - já em $1930,{ }^{3}$ o Anhanguera possuiu, em momentos diferentes, um considerável número de endereços de campos de futebol em bairros como a Casa Verde e o Bom Retiro, além da própria Barra Funda, sem nunca se afastar da várzea do Tietê.

Segundo William Sandonato, antigo associado do clube, o primeiro campo do Anhanguera localizou-se na Rua dos Americanos (mapa 2). ${ }^{4}$ A primeira sede esportiva fora instalada, ainda em 1928, ao lado dos campos dos clubes XV de Novembro do Bom Retiro e Carlos Gomes, também formados por ítalo-brasileiros moradores da várzea do Rio Tietê. A proximidade entre as sedes esportivas dos três clubes sugere que o arranjo de endereços para os campos passava pelas relações de vizinhança. Além disso, ao observar o detalhe da planta da cidade, é possível visualizar que no lado oeste da Rua dos Americanos não havia praticamente nenhum arruamento - devido às já citadas características do terreno: alagadiço e $\operatorname{argiloso}^{5}$-, o que explica a reunião dos três campos de futebol ali dispostos um ao lado do outro. Esse tipo de composição, aliás, não parecia incomum na região varzeana, como contam seus antigos moradores. O Sr. Amadeu, por exemplo, rememora que quando começou a jogar futebol, no início dos anos 1920, a cidade "tinha mais de mil campos de várzea. Na Vila Maria, no Canindé, na Várzea do Glicério, cada um tinha mais ou menos cinquenta campos de futebol. Barra Funda, Lapa, entre 20 e 25 campos". 6

Tão interessante quanto a noção do número de campos situados nos bairros mais afastados da cidade é a descrição do Sr. Amadeu acerca da paisagem varzeana e suburbana.

\footnotetext{
${ }^{3}$ O clube só mudaria o endereço de sua sede social em 1970, quando se transferiu para a Rua dos Italianos ao ganhar o estatuto de Clube da Comunidade, numa parceria com a Secretaria de Esportes do Município de São Paulo.

${ }^{4}$ Entrevista com o Sr. William João Sandonato, realizada em 23 de maio de 2010.

5 À semelhança da Rua do Córrego, onde o Anhanguera instalou sua sede social, a Rua dos Americanos era endereço muito próximo ao riacho retratado no mapa 2.

${ }^{6}$ Depoimento do Sr. Amadeu (BOSI, Ecléa. Memória e sociedade..., cit., p. 138).
} 
Com base na prática do futebol, com a qual esteve envolvido desde a infância, ${ }^{7}$ Amadeu indica não apenas um tipo de ocupação e uso predominante desses terrenos, mas, sobretudo, o modo como se deu a apropriação física e simbólica do espaço da várzea por seus moradores. Os conteúdos associados a essa apropriação podem ser identificados nos relatos dos varzeanos e em seus registros visuais, como na fotografia feita por um associado do Anhanguera (figura 9):

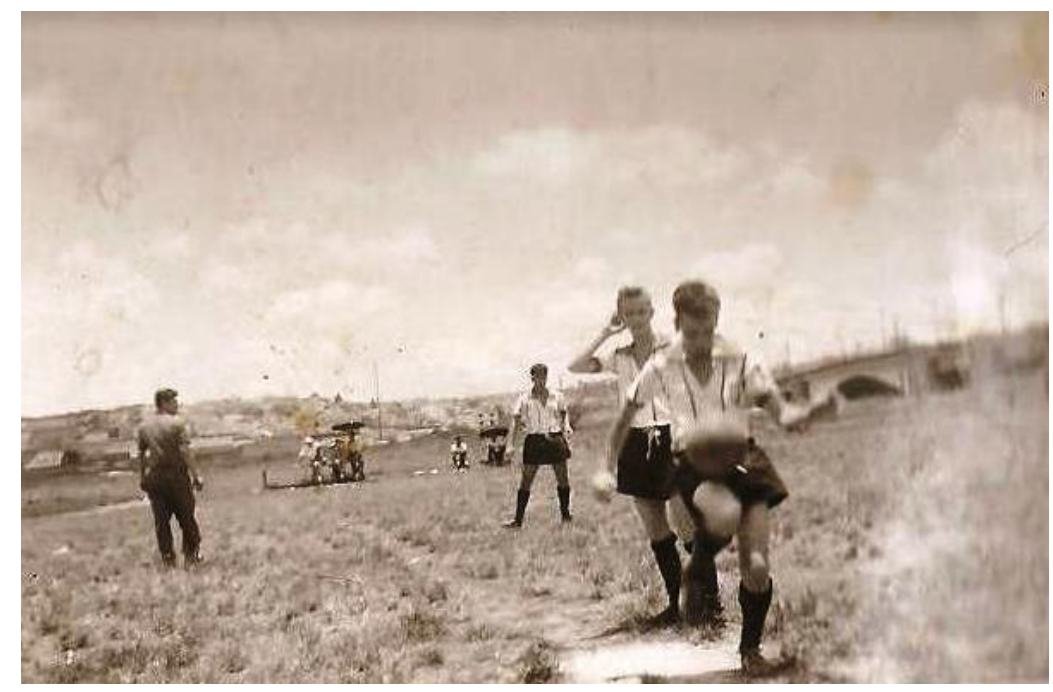

Figura 9 - Meninos jogam futebol em um dos campos do Anhanguera, anos 1930. (Fonte: Acervo do clube)

Esses documentos revelam o papel fundamental do futebol no processo de enraizamento dos ítalo-brasileiros, principalmente no que se refere à construção do sentimento de pertença aos bairros onde se estabeleceram. Não parece desprezível o fato de que o próprio Sr. Amadeu, na continuação de seu relato, relacione sua infância aos jogos de futebol:

a rua não tinha calçada [...] as crianças [...] ficavam à vontade naquelas ruas antigas. Eram ruas de lazer, porque não tinham o movimento [...] sempre se faziam parques para a meninada. Meus irmãos jogavam futebol juntos na rua. Tínhamos um clube, formado por nós, chamado Carlos Garcia. ${ }^{8}$

\footnotetext{
${ }^{7}$ Nascido no Brás, em 1906, o Sr. Amadeu começou a se envolver com o esporte aos 9 anos de idade.

${ }^{8}$ Depoimento do Sr. Amadeu (BOSI, Ecléa. Memória e sociedade..., cit., p. 125).
} 
O mesmo acontece com o Sr. Cirilo Magalhães, também associado ao Anhanguera:

eu era garoto, e a gente jogava com bola de meia, aquelas meias de mulher, a gente enrolava e brincava na rua... bola de meia... tinha aquelas bolas de capotão, que era uma bola enorme. Chovia e aquilo pesava três, quatro quilos...mas era da época... não existia o modernismo que existe hoje... era difícil mas pela vontade em qualquer rua tinha jogo de futebol. $O$ trânsito era bem menor também. ${ }^{9}$

Além de revelarem os recursos utilizados pelos pequenos representantes das comunidades estrangeiras para praticar o futebol, os relatos indicam que o espaço da várzea era valorizado na medida em que era associado à prática do futebol. ${ }^{10}$ Tratava-se, pois, de um espaço central no processo de enraizamento dos imigrantes à cidade. A região central lhes era hostil, ao passo que no subúrbio havia espaço para o exercício lúdico do futebol - esporte definidor de suas identidades sociais.

É a partir da importância do espaço no processo de enraizamento que se pode compreender a escolha dos fundadores do Anhanguera pelo nome da rua que acolheu sua reunião de fundação. Muitas vezes, os nomes dos times remetiam “à noção de lugar e de localidade. O lugar indicava o conteúdo social que podia ser o do time de fábrica, do time da loja, da repartição ou da colônia". ${ }^{11}$ A localidade, por sua vez, equivaleria "à localização no espaço da cidade e do seu entorno". ${ }^{12}$ A rivalidade entre Anhanguera e Carlos Gomes pode ser entendida sob esse prisma. Basta lembrar que, após quinze anos, a Rua Anhanguera deixou de ser uma exclusividade do clube fundado em 1913 para abrigar, em 1928, o clube dissidente que adotara o nome da via.

De todo modo, ao menos no que se refere às sedes esportivas, a vizinhança entre os clubes não parece ter se prolongado na Rua dos Americanos. Em 1929, A Gazeta Esportiva se

\footnotetext{
${ }^{9}$ Entrevista realizada com o Sr. Cirilo Magalhães, realizada em 12 fev. 2011. Cirilo nasceu em 1933.

10 Algo também entrevisto nas crônicas de Alcântara Machado como, por exemplo, "Gaetaninho". Cf. MACHADO, Alcântara. Brás, Bexiga e Barra Funda..., cit., p.22.

${ }^{11}$ SEABRA, Odette Carvalho de Lima. Urbanização e fragmentação..., cit., p. 361.

${ }^{12}$ Ibid.
} 
referia a outro endereço do Anhanguera: “A. A. Anhanguera x America F.C.; perante enorme assistência, defrontaram-se hontem, no campo da Rua Visconde de Taunay, os quadros do clube local e os do America F.C". ${ }^{13}$ Embora a Rua Visconde de Taunay (mapa 2) integrasse o bairro do Bom Retiro e não a Barra Funda, como a nota pode fazer crer, ${ }^{14}$ não se sabe se o citado campo correspondia a um endereço fixo do Anhanguera. Talvez se tratasse apenas de um aluguel provisório ou mesmo de um empréstimo, sendo esses dois expedientes muito comuns à época, sobretudo entre associações que não podiam arcar com os valores mensais de um aluguel permanente.

Talvez por essa razão, já no início de 1930, a assembleia que reunia a presidência e a diretoria do clube deliberou "fazer o campo de futebol nos terrenos de propriedade do Sr. Matheus Sabatini e Miguel Vignola", ${ }^{15}$ numa tentativa de não mais depender daquelas alternativas. Na reunião seguinte, entretanto, o clube se depara com um dilema diante dos

senhores os quaes [...] trabalhando no [...] campo queixaram-se que não poderiam continuar a tarefa do campo por ser muito pouco a parcela por elles tratada, a qual monta $160 \$ 000$, exigindo a quantia de $300 \$ 000$, ficando a cargo do Sr. Miguel Vignola resolver o caso. ${ }^{16}$

Apesar de não haver outras referências ao caso, o clube não parece ter conseguido arcar com as novas despesas previstas para construir seu campo de futebol, uma vez que continuou circulando em outros campos da várzea. ${ }^{17}$ Ainda sobre esse episódio, não se pode deixar de notar que Sabatini e Vignola estavam, uma vez mais, agenciando outro terreno de sua propriedade junto ao clube. O que também não representava novidade entre varzeanos, como se entrevê na continuação do relato do Sr. Amadeu:

\footnotetext{
${ }^{13}$ A Gazeta Esportiva, 4 nov. 1929, p. 6.

${ }^{14}$ A Avenida Rudge representa o marco de separação entre os bairros, como se vê no mapa 2.

${ }_{16}$ Atas da Associação Atlética Anhanguera, 14 abr. 1930.

${ }^{16}$ Ibid., 21 abr. 1930.

${ }^{17}$ Processo que, em verdade, só terminaria no ano de 1970, quando o Anhanguera se transforma em um Clube da Comunidade.
} 
a maior parte dos campos [de futebol da várzea] eram dados pelos donos para o lugar progredir, popularizar. O dono é que pedia pra fazerem um campo nesses terrenos baldios. Quando tinha um clube, vinha o progresso. No domingo, vinham 2 mil pessoas assistir e começava o comércio, o progresso. ${ }^{18}$

A essa altura sabemos que, ao menos no que se refere ao Anhanguera, os proprietários não realizavam exatamente uma doação de seus terrenos. ${ }^{19}$ Em todo caso, as lembranças do Sr. Amadeu reafirmam a importância assumida pelo futebol nos negócios movimentados nos bairros onde se estabeleceram tanto os vários campos quanto os clubes esportivos que deles usufruíram.

O comércio, um dos ramos mais ativos entre ítalo-brasileiros da região varzeana, também parecia beneficiar-se do interesse pelo futebol. Ao final da Rua do Bosque, por exemplo, havia uma grande concentração comercial em razão da circulação de pessoas que moravam nas inúmeras vilas operárias da Ferrovia Sorocabana, ou eram deixadas no último ponto da linha de bondes que fazia a ligação com o centro da cidade.

Sabatini e Vignola faziam parte do grupo que, além de terrenos, possuía "vendas" na região da Rua do Bosque onde se comercializavam "tomates, pepinos, aspargos e melões", alimentos popularizados pelos imigrantes juntamente com o costume de, naqueles mesmos espaços, "saborear massas à bolonhesa e beber vinhos de fabricação caseira". ${ }^{20}$ Esses últimos não eram disputados apenas nas rodas de passatella, mas integravam também as apostas futebolísticas.

Dois anos após a tentativa de construir campo próprio, no entanto, o clube é associado pela Folha da Manhã ao endereço da Rua Lopes de Oliveira, localizada na Barra Funda de

\footnotetext{
${ }^{18}$ Depoimento do Sr. Amadeu (BOSI, Ecléa. Memória e sociedade..., cit., p. 138).

${ }^{19}$ Sobre esse aspecto, Seabra chega a considerar que, num primeiro momento, "os clubes e os donos de clubes formaram patrimônios" (Urbanização e fragmentação..., cit., p. 355).

${ }^{20}$ GUNN, Philip; CORREIA, Telma de B. Vilas operárias: o mundo fabril penetra na cidade. In: CAMPOS, Cândido M.; GAMA, Lúcia Helena; SACCHETA, Wladimir. São Paulo: metrópole em trânsito, percursos urbanos e culturais. São Paulo: Ed. Senac, 2004, p. 94.
} 
cima (mapa 2). Ainda que os relatos dos veteranos não mencionem esse local, o periódico a ele se refere em uma curiosa seção, intitulada "aggressões":

Quando se realizava uma partida de futebol no campo da Associação Athletica Anhanguera, na Rua Lopes de Oliveira, Antonio de Oliveira, de 29 annos, residente à Rua do Bosque, 177, foi aggredido a soccos por Sunin de tal, recebendo escoriações e contusões no rosto. ${ }^{21}$

Embora não tenham sido encontrados outros elementos sobre o caso, a nota que se atém aos endereços do campo de futebol e da moradia de Antonio de Oliveira, o agredido, sugere que o soco desferido tivesse relação com as tensões que envolviam a Barra Funda de cima e a de baixo. Brigas e confrontos físicos entre os grupos que moravam em diferentes regiões do bairro não eram incomuns, pois, além de "bêbados", as ruas da Barra Funda de baixo também concentravam grandes "arruaceiros", segundo relatou o Sr. Ângelo Catapano. ${ }^{22}$ Alguns deles eram bastante conhecidos e receberam a alcunha de "os cabeleiras". ${ }^{23}$ Suas proezas são associadas à desordem e à violência, já que o grupo perambulava pelas ruas da Barra Funda de baixo em busca de "aventura", "confusão" e briga, principalmente com membros do Anhanguera, de quem eram rivais. Os cabeleiras moravam no bairro do Bom Retiro de baixo ${ }^{24}$ e frequentavam as conhecidas jogatinas de carteado do Grupo Esportivo Carlos Gomes. Acumulavam, portanto, não apenas a rivalidade em torno dos dois clubes, mas

\footnotetext{
${ }^{21}$ Folha da Manhã, nov. 1932, p. 11.

${ }^{22}$ Cf. BRUNELLI, Aideli S. Urbani et al. Barra Funda, cit., p. 20. Ângelo Catapano, já falecido, era um profundo conhecedor da Barra Funda e, além de associado ao Anhanguera, era também o responsável pelo contato com A Gazeta Esportiva, ao que retornaremos no terceiro capítulo.

${ }^{23}$ Ibid. Assim apelidados em razão dos penteados avantajados e das vestimentas particulares. O grupo, exclusivamente masculino, era formado pelos jovens membros de uma mesma família, da qual não se possui referências.

${ }^{24}$ Assim como a Barra Funda, o Bom Retiro também foi dividido ao meio pela ferrovia e, por essa razão, nele se estabeleceram clivagens semelhantes àquelas que ocorreram na Barra Funda, embora a presença de imigrantes ali fosse muito mais diversificada devido à maciça presença de libaneses, portugueses, gregos, entre outros. De todo modo, para grande parte dos veteranos do Anhanguera: "se existe um bairro [...] em que as relações se dão da mesma maneira é a Barra Funda de baixo com o Bom Retiro de baixo. As duas partes de cima são outra coisa, não tem nada a ver" (entrevista com Arthur Tirone e "Grego", realizada em 25 de junho de 2011). Arthur Tirone relata essas diferenças a partir do diálogo com as memórias de seu avô, Oswaldo Tirone. Além de ser um dos representantes da terceira geração da família no clube, Arthur é também considerado o historiador do Anhanguera.
} 
também aquela que se criou entre os bairros, pois os imigrantes instalados no Bom Retiro eram mais abastados que os da Barra Funda.

A movimentação do Anhanguera pelo bairro em busca de novos endereços ${ }^{25}$ onde pudesse estabelecer sua sede esportiva nesses primeiros anos de atividade vai descortinando os microprocessos de configuração do espaço urbano - ou suburbano - pela comunidade varzeana e remete às práticas microbianas sobre as quais se refere Michel de Certeau. ${ }^{26}$

Ela não só evidencia o domínio de procedimentos simples e eficazes, como acompanhar o Diário Oficial "na parte que se refer[ia] aos terrenos baldios da municipalidade", 27 mas também sugere a capacidade de negociação de suas sucessivas diretorias com os poderes locais, públicos ou privados ${ }^{28}$ - instâncias, aliás, às quais parte desses diretores pertencia.

Não fosse assim, possivelmente o clube teria sucumbido como dezenas de agremiações e associações esportivas que encerraram definitivamente suas atividades após perderem a possibilidade de dispor dos espaços onde eram instalados seus campos de futebol. Tais perdas eram causadas por exigência tanto dos proprietários quanto da prefeitura, que constantemente "vinha tirar" 29 a licença de uso dos espaços, ${ }^{30}$ o que se tornava cada vez mais

\footnotetext{
${ }^{25}$ O que não acabou na década de 1930 . Segundo os veteranos do clube, foram dez ou onze endereços diferentes até o estabelecimento, em 1970, à Rua dos Italianos. É interessante notar que os endereços mencionados pelos veteranos não coincidem com os citados por uma reportagem da época: "O clube teve campo duas vezes na Rua Visconde de Taunay, uma vez na Avenida Rudge, duas na Rua Luzitania, duas na Rua dos Americanos, duas na Rua Padre Luis, duas na marginal esquerda do Tietê, perto da Ponte da Casa Verde" (A Gazeta Esportiva, 9 ago. 1971, p. 12). O descompasso entre os endereços citados pelo periódico e pelos veteranos também aparece em relação à forma como tais endereços são apresentados: informações sucintas e busca de precisão marcam o discurso do jornal, enquanto uma pluralidade de referências espaciais e temporais pautadas na experiência cotidiana caracteriza as indicações dos sócios.

${ }^{26}$ A invenção do cotidiano..., cit.

${ }^{27}$ Atas da Associação Atlética Anhanguera, 16 jun. 1931.

${ }^{28}$ Não se pode esquecer da igreja católica, que ainda possuía muitos terrenos no início do século XX e os negociou com entidades esportivas. O campo do A.A.Açucena, fundado em 1924, no bairro do Limão, "era metade de propriedade da paróquia e metade de propriedade particular, pertencente a um morador" (SEABRA, Odette Carvalho de Lima. Urbanização e fragmentação..., cit., p. 339).

${ }^{29}$ Entrevista com Arthur Tirone, realizada em 25 de junho de 2011.

${ }^{30}$ Só na região da Barra Funda e do Bom Retiro, entre o início dos anos 1940 e a década de 1960, desapareceram as seguintes entidades: Clube Atlético Estados Unidos; Clube Royal; Clube São Geraldo; Clube Nacional do Bom Retiro; São Cristóvão Esporte Clube; Corinthians do Bom Retiro; Associação Atlética Barra Funda;
} 
frequente naqueles anos de 1930, em razão das transformações urbanas pelas quais a cidade vinha passando, muitas delas decorrentes do Plano de Avenidas do urbanista Prestes Maia. ${ }^{31}$

Não se pode esquecer que, embora menos agressivo num primeiro momento, o plano também chegou à Barra Funda de baixo. $\mathrm{Na}$ região da várzea, a proposta era alterar e controlar o curso das águas e o espaço de vazão do Rio Tietê. A medida visava promover a salubridade - por meio da redução do número de enchentes no local - e a fluidez na circulação de mercadorias e de pessoas - a partir da criação de um anel viário às margens do rio, futuramente conhecido como Via Professor Simão Faiguenboim ou simplesmente Marginal Tietê. Além da desapropriação de terrenos, o plano também incluía, como vimos em relação à Várzea do Carmo, uma espécie de programa sobre como a região deveria ser vivida por seus habitantes, o que se entrevê nos comentários do futuro prefeito de São Paulo a respeito da várzea do Tietê:

Conjuntos monumentais, parkways, paisagismo, instalações esportivas, circulação rápida, linhas de alta velocidade, navegação, vias férreas, cais, indústrias, etc., são matéria vastíssima e interconexa, apenas entrevista pela maioria dos munícipes. Assim considerada, e não como mera obra de drenagem, a canalização pode tornar-se um elemento importante de urbanização. Que não possamos daqui a 30 anos repetir o crítico portenho e, em vez de terrenos ganados al rio, dizer: possibilidades perdidas para São Paulo. $^{32}$

Essa perspectiva, cujo centro está na ideia de conquista de espaço ao rio - para ser ocupado e regulado por um ritmo intenso e artificial -, foi traduzida numa série de ações públicas que "impôs progressivamente a homogeneização de um modo de viver em nome do

Democráticos Futebol Clube; XV de Novembro; Bola Preta; Junqueira; Garibaldi Futebol Clube; Grajaú; Bola Sete; Sul Americano; Grupo Esportivo Carlos Gomes; Faísca de Ouro; Flor do Bosque; Santos da Barra Funda; Paulista; Camerino.

31 O plano foi concebido em 1930 pelo engenheiro Francisco Prestes Maia, que, em contraste com o posicionamento do também engenheiro e então prefeito Anhaia Mello, criou as condições para a expansão horizontal da cidade. Esta seria reordenada a partir de modelo urbanístico inspirado num sistema radial e perimetral de avenidas, com o objetivo de descentralizar o setor comercial e de serviços e distribuir a circulação por ruas secundárias, ampliando a fluidez no tráfico (Cf. HAAG, Carlos. A cidade dos engenheiros. Pesquisa FAPESP, São Paulo, n. 178, dez. 2010. Cf., ainda, SEVCENKO, Nicolau. Orfeu extático na metrópole..., cit.).

32 PRESTES MAIA apud CUSTÓDIO, Vanderli. Dos surtos urbanísticos do final do século XIX ao uso das várzeas pelo Plano de Avenidas. Geosul, Florianópolis, v. 19, n. 38, p. 77-98, jul./dez. 2004, p. 88. 
progresso, da técnica e da razão". ${ }^{33}$ Em um processo semelhante ao que empreendera Washington Luís, Prestes Maia desejava integrar a várzea à cidade abstraindo a paisagem e as pessoas, cuja existência concreta não parecia ser por ele reconhecida ou legitimada. É eloquente o fato de que, em seu relatório, não sejam encontradas quaisquer referências aos munícipes da região, os varzeanos; ${ }^{34}$ ademais, ao mesmo tempo, o Desinfectório do Bom Retiro $^{35}$ ainda estava em plena atividade no controle de doenças - e pessoas - que ameaçavam à saúde pública. Como ainda prevaleciam as teorias miasmáticas de transmissão de doenças, segundo as quais o contágio se dava fundamentalmente pelo contato com um doente, um dos focos de ação era justamente o isolamento de possíveis promotores de tais moléstias. ${ }^{36}$ Esse critério atingia de forma direta os moradores da várzea, cujas habitações estavam constantemente sujeitas a inundações do Rio Tietê e dos córregos que o ladeavam.

Em geral, a população não compreendia nem as razões, nem as formas pelas quais se realizavam esses procedimentos. Nesse período, Oswaldo Tirone e Antenor Dias, associados do Anhanguera, "morriam de medo de serem levados pela polícia para o desinfectório", 37 o que os levou, em certas ocasiões, a modificar seus trajetos noturnos dos bares e meretrícios do Bom Retiro e da Luz para suas respectivas casas. Para escaparem do controle da polícia e de uma possível internação no desinfectório, eles passavam das ruas que davam acesso à Barra Funda aos trilhos do trem, margeando a Barra Funda de cima até chegarem à Rua Anhanguera.

\footnotetext{
${ }^{33}$ RAGO, Margareth. A invenção do cotidiano na metrópole..., cit., p. 388.

${ }^{34}$ Perspectiva divergente da adotada por Anhaia Mello, prefeito entre 1930 e 1931, que ao menos em seus planos urbanísticos citava esses cidadãos, tal como no trecho a seguir: "construir belas cidades e viver nelas em beleza exigia preparar o ambiente e formar uma psicologia urbana e anseio cívico, uma opinião pública esclarecida. Era preciso 'limitar a expansão indefinida e desordenada de São Paulo' e 'criar espaços de lazer para os operários"” (HAAG, Carlos. A cidade dos engenheiros, cit.). Evidentemente, a análise se refere aos textos e não às políticas implementadas pelos urbanistas.

35 Instalado em fins do século XIX na esquina da antiga Rua Itaboca - significativamente transformada em Rua Professor Cesare Lombroso - com a Rua Tenente Pena (mapa 2).

${ }^{36}$ Trata-se da prática da quarentena, do isolamento do doente por quarenta dias, razão pela qual o desinfectório foi instituído.

${ }^{37}$ Entrevista com o Sr. Cirilo Magalhães e com o Sr. Augusto Pereira Neto (Carioquinha), realizada em 12 de fevereiro de 2011.
} 
Assim, além de não serem compreendidos como munícipes pelo poder público, os varzeanos sentiam-se ameaçados pelas políticas sanitárias que integravam os planos de urbanização da cidade. Diante desse quadro, só lhes restava criar soluções para escapar à homogeneização imposta pelo controle dos setores de polícia e higiene a fim de continuarem dispondo de espaços para praticar seu futebol. Para isso, os varzeanos valeram-se, inclusive, de negociações com os representantes locais da municipalidade. Em alguns casos, eles parecem ter sido bastante hábeis, haja vista sua longevidade na região, caso do próprio Anhanguera.

Essa capacidade de negociação com os poderes locais foi, portanto, um elemento central para que o Anhanguera e outros clubes esportivos permanecessem atuantes na várzea a despeito do tipo de urbanização empreendida na cidade já nos anos 1930. Tal capacidade não foi, no entanto, o único elemento a explicar essa estabilidade. É preciso voltar-se para a dinâmica interna das associações para compreender, por exemplo, o papel das receitas mensais nessa permanência.

\subsection{Associação: adoção e demissão de novos associados}

Embora festas e bailes representassem uma fração importante da renda da Associação Atlética Anhanguera, fazia-se "tudo com o dinheiro que entrava do recibo dos associados", 38 conta William Sandonato, indicando a centralidade dessa modalidade de recursos. Ao que parece, tal centralidade era parte significativa da razão pela qual o clube instaurara procedimentos pouco restritivos para a incorporação de novos sócios. As propostas eram tão importantes na dinâmica do clube, que constituíam a única seção regular nas atas das assembleias, registradas de acordo com o seguinte padrão (figura 10):

\footnotetext{
${ }^{38}$ Entrevista com o Sr. William João Sandonato, realizada em 23 de maio de 2010.
} 


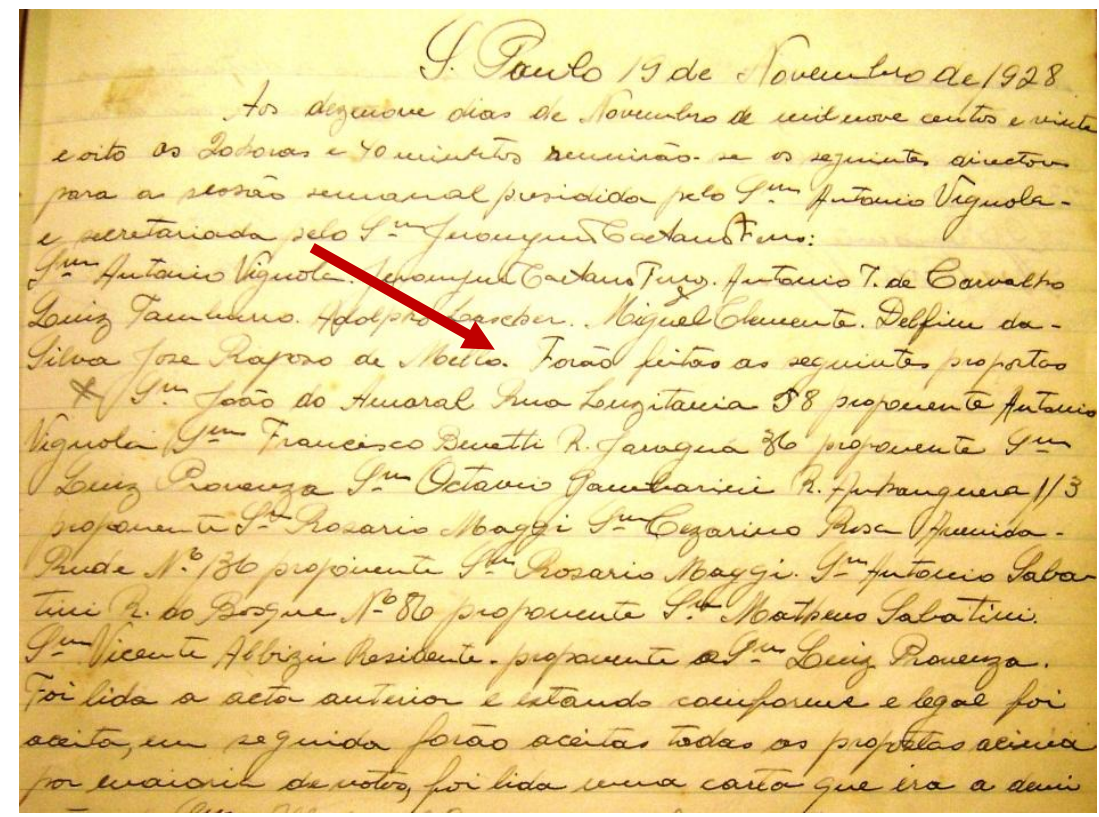

Figura 10 - Reprodução de ata da Associação Atlética Anhanguera, 19 nov. 1928. (Fonte: Acervo do clube)

Para se associar ao Anhanguera, era necessário ser convidado por alguém já pertencente ao clube - com mais de três meses na casa -, que se tornaria então uma espécie de padrinho responsável pelo novato, ou seja, por suas eventuais dívidas caso houvesse inadimplência quanto ao pagamento dos recibos. Havia certo padrão nesse apadrinhamento, como se nota nos dados presentes na amostra do seguinte quadro: ${ }^{39}$

\begin{tabular}{|c|c|c|c|c|}
\hline $\begin{array}{l}\text { Número } \\
\text { da } \\
\text { proposta }\end{array}$ & $\begin{array}{c}\text { Data da } \\
\text { assembleia }\end{array}$ & Nome do proposto & $\begin{array}{c}\text { Endereço } \\
\text { do proposto }\end{array}$ & $\begin{array}{c}\text { Nome } \\
\text { do } \\
\text { proponente }\end{array}$ \\
\hline 15 & \multirow{6}{*}{ 28/01/1929 } & Manoel da Costa & Rua Salta Salta, 52 & José Fernandes \\
\hline 16 & & Antonio V. & Rua Salta Salta, 24 & Antonio Satriani \\
\hline 17 & & Octacílio Pereira & Rua Baixa, 10 & Bartholomeu Maggi \\
\hline 18 & & Francisco Castelhano & Rua Javahés, 34 & Antonio Satriani \\
\hline 19 & & Amadeu Althiere & Rua Javahés, 16 & Antonio Satriani \\
\hline 20 & & Joaquim seixas & Rua Guaianazes, 170 & Antonio Satriani \\
\hline 21 & \multirow{5}{*}{ 26/02/1929 } & Arthur Ricco & Sem referência & João Maggi \\
\hline 22 & & Marcilio Luchi & Rua Prates, 47 & Antonio C. de Carvalho \\
\hline 23 & & H. Brandt & Alameda Barão de Piracicaba, 78 & Antonio C. Carvalho \\
\hline 24 & & B. Guimarães & Sem referência & Claudionor Thofaldi \\
\hline 25 & & Raul Lourenço & Rua Salta Salta, 16 & Anthenor Monteiro \\
\hline
\end{tabular}

\footnotetext{
${ }^{39}$ Elaborado a partir dos dados recolhidos nas Atas da Associação Atlética Anhanguera.
} 


\begin{tabular}{|c|c|c|c|c|}
\hline 26 & \multirow{3}{*}{ 04/03/1929 } & Emilio Mazzela & Rua Cruzeiro, 16 & João M. \\
\hline 27 & & Teciano Bissagua & Rua Conselheiro Brotero, 44 & Emilio Bertucci \\
\hline 28 & & José Bastos & Rua Salta Salta & Delfim da Silva \\
\hline 29 & \multirow{14}{*}{$11 / 03 / 1929$} & José Felix Martins & Rua Largo Coração de Jesus, 15 & Rogério Pavani \\
\hline 30 & & Domingues Marcello & Rua Victorino Carneiro, 129 & D. Victorelli \\
\hline 31 & & Placito Coelho & Rua da Várzea, 6 & Manoel Gonçalves \\
\hline 32 & & David Bastos & Alameda Eduardo Prado, 68 & Eduardo Faria \\
\hline 33 & & Luiz A. Pires & Alameda Eduardo Prado, 50 & Eduardo Faria \\
\hline 34 & & Boamergis Guimarães & Sem referência & Claudionor [?] \\
\hline 35 & & Orestes D. & Sem referência & Bartholomeu Maggi \\
\hline 36 & & Antonio Lacava & Rua Garibaldi, 34 & Antonio Satriani \\
\hline 37 & & Roque Deodoro & Praça da Republica, 28 & Antonio Satriani \\
\hline 38 & & José (?) & Rua dos Americanos & Orlando Pontes \\
\hline 39 & & Carlos Corrêa & Sem referência & Alfredo Sá \\
\hline 40 & & Benedicto Barbosa & Rua do Córrego, 7 & Orestes D. \\
\hline 41 & & Alfredo Bertoloci & Rua Anhanguera, 7 & João Hidro \\
\hline 42 & & Jiovani Francisco & Alameda Nothman & Alfredo Bertoloci \\
\hline 43 & \multirow{4}{*}{$18 / 03 / 1929$} & Rafael Lourenço & Rua Bosque, 102 & João Cidro \\
\hline 44 & & Carmo Pietoso & Rua Anhanguera, 39 & Fernando Costa \\
\hline 45 & & Alvaro Costa & Rua Anhanguera, 60 & José de Agostinho \\
\hline 46 & & Silvio da Conceição & Rua Gomes Cardim, 164 & João A. Gross \\
\hline 47 & \multirow{2}{*}{ 25/03/1929 } & Antonio Carlucci & Rua Bosque, 19 & Fortunato R. \\
\hline 48 & & Miguel Daurêa & Rua Garibaldi, 4 & Saverio Russo \\
\hline 49 & $01 / 04 / 1929$ & Antonio d Abril & Rua Barão de Tatuy, 154 & Miguel Branca \\
\hline 50 & $08 / 04 / 1929$ & Domingues Brás & Sem referência & Antonio Vignola \\
\hline 51 & \multirow{7}{*}{$15 / 04 / 1929$} & José Manoel & Sem referência & João Bello \\
\hline 52 & & Januário Pascoalucci & Rua Manoel Dutra, 83 & Carlos Virgilo \\
\hline 53 & & Eloy Treviziaki & Rua Barra Tibagi, 146 & Fortunato R. \\
\hline 54 & & Amadeu Biau & Rua Conselheiro Nebias, 115 & João A. Giovani \\
\hline 55 & & Bertholdo V. & Rua Xavier de Toledo, 60 & João A. \\
\hline 56 & & João Bello & Sem referência & Orlando Pontes \\
\hline 57 & & Renato Limões & Rua Bosque, 75 & Manoel M. \\
\hline 58 & \multirow{2}{*}{ 25/04/1929 } & Santino Manoel Soares & Rua Duque de Caxias, 39 & João A. Gross \\
\hline 59 & & João Seaglia & Rua Siva Pinto, 13 & João A. Gross \\
\hline 60 & & Antonio Orelo & Rua 13 de Maio, 26 & Amadeu Bianchi \\
\hline 61 & & Manoel Souza & Estrada da Limão, 13 & Carlos Virgilo \\
\hline 62 & & Antonio Riorni & Rua Boracéa, 49 & Antonio Althiere \\
\hline 63 & \multirow{2}{*}{ 07/05/1929 } & Sivio Lima & Rua Anhanguera, 28 & Ezzio Marchetti \\
\hline 64 & & Osvaldo Bicudo & Rua Garibaldi, 2 & O. Monteiro \\
\hline 65 & \multirow{3}{*}{ 14/05/1929 } & João Russo & Rua do Bosque, 56 & João Paris \\
\hline 66 & & João N. & Rua Barra Funda, 113 & Miguel Vignola \\
\hline 67 & & Francisco Tezzi & Rua Luzitania & Antonio Althiere \\
\hline 68 & \multirow{6}{*}{ 04/06/1929 } & Angelo Barbarulo & Rua Ribeiro da Silva, 59 & Joaquim Seixas \\
\hline 69 & & Libertário Court & Alameda Barão de Limeira, 203 & Joaquim Seixas \\
\hline 70 & & Antonio Casuccio & Rua Silva Pinto, 3 & Amadeu Biau \\
\hline 71 & & Caetano Gross & Av. Rudge, 74 & Miguel Branco \\
\hline 72 & & Francisco Viscardi & Rua Javahés, 13 & Amadeu Althiere \\
\hline 73 & & Antonio Soares & Rua Salto Salto, 48 & Arsenio Gentil \\
\hline
\end{tabular}




\begin{tabular}{|l|l|l|l|l|}
\hline 74 & \multirow{2}{*}{} & Salvador Arquiar & Rua Joaquim, 88 & Jayme Gomes \\
\cline { 3 - 4 } & Miguel Paris & Rua do Bosque & Miguel Satriani \\
\hline
\end{tabular}

O caso de Amadeu Althiere, filiado em 1929, é exemplar dessas práticas na associação. Em 28 de janeiro, ele é proposto - juntamente com Francisco Castelhano, ambos moradores da Rua Javahés, no Bom Retiro - por Antonio Satriani, o marceneiro. Em 4 de junho, é ele quem propõe um de seus vizinhos, o Sr. Francisco Viscardi. ${ }^{40}$ Amadeu não parecia ser o único Althiere a circular pelo clube, pois Antonio Althiere também vinha realizando propostas durante o primeiro semestre de 1929, como se observa nos meses de abril e maio. $^{41}$

Casos como o de Amadeu $^{42}$ revelam que os convites desses associados vinculavam-se aos seus locais de moradia ou trabalho - em muitos casos coincidentes, tal como vimos no que se refere aos trabalhadores de ofícios. ${ }^{43}$ Assim, vizinhos, colegas de trabalho e também familiares eram convidados a integrar o clube por simples associados e por diretores - como Miguel Vignola, Antonio e Miguel Satriani, Ezzio Marchetti, Joaquim Seixas, João Cidro, Saverio Russo e Bartholomeu Maggi, além do presidente, que naquele ano era Antonio Vignola -, o que revela uma centralização da diretoria do clube no mecanismo de incorporação de novos sócios naquele momento. Tratava-se, evidentemente, de mais uma maneira de garantir certo controle sobre os perfis dos sócios desejados pelo Anhanguera. Esse era um expediente comum entre as entidades populares, que não raramente continham em

\footnotetext{
${ }^{40}$ Pertencente a uma das poucas famílias que verdadeiramente enriqueceram na região a partir do engajamento no ramo automobilístico. Os Viscardi são donos de uma importante concessionária de veículos na cidade, segundo os veteranos do clube Anhanguera.

${ }^{41} \mathrm{O}$ registro de sua própria proposta não foi localizado, podendo, inclusive, ter sido assentado em volume anterior ao das atas analisadas neste trabalho.

42 Apenas nessa amostra é possível acompanhar também o movimento de Eduardo Faria. Em outros períodos, pode-se explorar aspectos do âmbito profissional, da dimensão geracional e da situação conjugal dos associados; a algumas dessas questões voltaremos a seguir.

${ }^{43}$ Nos anos 1940, no entanto, são instaladas quatro importantes indústrias no bairro da Barra Funda, o que muda o perfil de trabalho dos varzeanos: a maior parte deles torna-se operária a partir de então. Segundo os veteranos, o padrão de associação ao clube é pouco alterado porque tanto a circulação no bairro, quanto as relações de vizinhança, base dessa sociabilidade, foram mantidas.
} 
seus estatutos itens que auxiliavam a seleção dos propostos, como o pedido de documentos que comprovassem serem eles praticantes de "ocupação decente e honesta". ${ }^{44}$ Reiterava-se, assim, a importância de possuir meios valorosos para garantir o vínculo com o clube, o que indica que tais associações não dispensaram critérios seletivos na formação de seus quadros.

Tais elementos ajudam a tecer um rápido e necessário comentário sobre a identidade étnica $^{45}$ das associações esportivas e sociais da várzea do Rio Tietê. Entre o fim dos anos 1910 e a década de 1930, elas foram fundadas por inúmeras comunidades imigrantes,

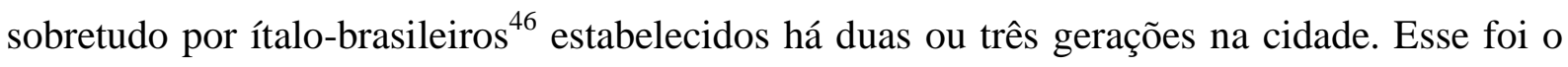
caso do Anhanguera, mas também do clube Nacional do Bom Retiro, do Grupo Esportivo Carlos Gomes, ambos de 1913, do Garibaldi Futebol Clube (que se tornou Grajaú durante a Segunda Guerra Mundial), do clube Barra Funda, do clube Sul-Americano e do clube Camerino. ${ }^{47}$ Ainda quanto à questão étnica - isto é, sem aqui considerar as associações tecidas a partir de outros elementos identitários ${ }^{48}-$, há que se citar as comunidades formadas por nacionais negros, como o União Futebol Clube, ${ }^{49}$ o Clube Royal ${ }^{50}$ e o São Geraldo Futebol Clube, cujas peculiaridades valeriam uma pesquisa aprofundada.

Assim como o Anhanguera, as associações ítalo-brasileiras mantinham traços muito próprios às culturas de origem, como a valorização dos elos familiares ou a prática da passatella, conforme indicado no capítulo anterior. Ao mesmo tempo, elas não deixaram de se

\footnotetext{
${ }^{44}$ SIQUEIRA, Uassyr de. Clubes recreativos..., cit., p. 281.

${ }^{45}$ Aqui compreendida a partir da ideia de que "as identidades e os elos sociais não têm natureza, mas apenas usos" (LEPETIT, Bernard. A história leva os atores a sério?... cit., p. 239), e de que "a etnicidade não se define como uma qualidade ou uma propriedade ligada de maneira inerente a um determinado tipo de indivíduo ou grupo, mas como uma forma de organização ou um princípio de divisão do mundo social cuja importância varia de acordo com as épocas e situações" (SIQUEIRA, Uassyr de, op. cit., p. 288-289).

${ }^{46}$ Sendo as luso-brasileiras também muito representativas na várzea, principalmente no Bom Retiro.

${ }^{47}$ Suas histórias são conhecidas apenas por relatos de ex-associados que, em face do desaparecimento de seus clubes, foram incorporados em clubes como o Nacional e o Anhanguera.

${ }^{48}$ Como as sociedades de "base operária dos mais diversos tipos (mutualistas, beneficentes, classistas, recreativas e culturais), como: Liga Operária do Bom Retiro, União dos Trabalhadores Ferroviários, Liga Internacional dos Marceneiros e uma sucursal da União dos Trabalhadores em Fábricas de Tecidos" (SIQUEIRA, Uassyr de. Clubes e sociedades dos trabalhadores do Bom Retiro..., cit., p. 68).

${ }^{49}$ SANTOS NETO, José Moraes dos. Visão de jogo..., cit., p. 53.

${ }^{50}$ Mesmo sendo mais ativo nos bailes, possuiu alguns quadros de futebol.
} 
integrar à cultura local, mesmo porque dela já faziam parte, pois, como nota Jacy Seixas: “para aqueles imigrantes que, mesmo decepcionados pelas condições de trabalho, não tornam a partir [...], mas se fixam e têm filhos; as novas gerações vem suavizar e reconciliar a parte estrangeira e brasileira das populações". ${ }^{11}$

É preciso, portanto, ter cuidado com adjetivações como "clube de colônia" para verificar como se davam esses vínculos identitários de base étnica no cotidiano dessas associações, lembrando, ainda, que a relação entre indivíduos não necessariamente correspondia àquela que se dava entre suas comunidades. Assim, por exemplo, nem sempre tais entidades restringiam a circulação ou a associação de outros grupos em suas dependências. ${ }^{52}$ Como vimos, as tensões entre a Barra Funda de cima e a de baixo em muito se relacionavam à presença negra na parte alta e ítalo-brasileira na parte baixa. No entanto, o Anhanguera possuía sócios negros desde os seus primeiros anos de atividade (figuras 11 e 12). Para William Sandonato, ex-presidente da associação, isso acontecia porque "ninguém fazia pouco caso de ninguém ali". 53
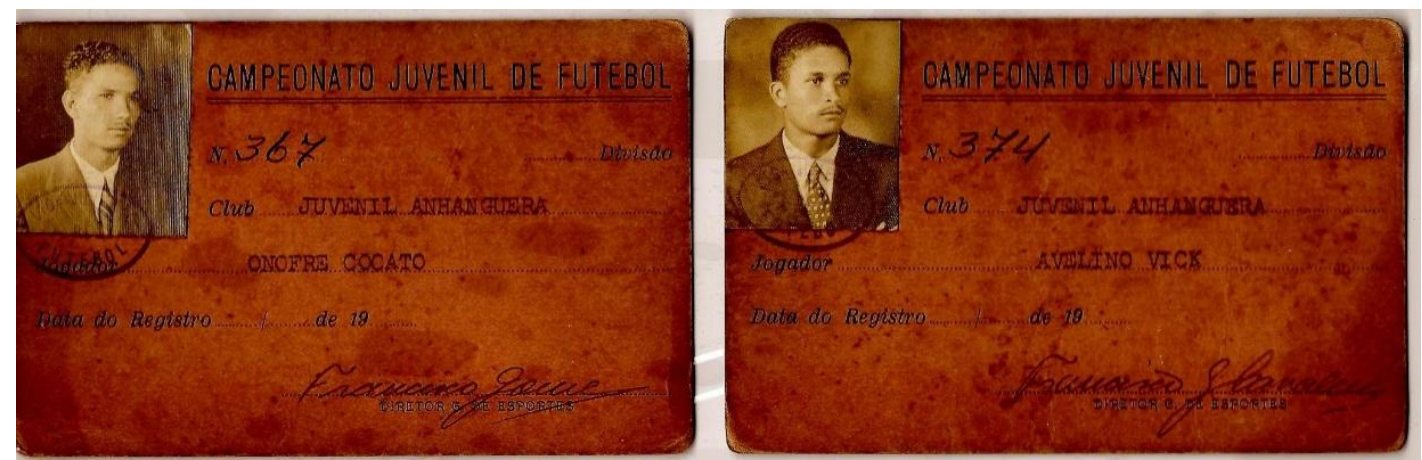

Figura 11 - Reprodução das fotografias de carteirinhas de associados, s.d. (Fonte: Arquivo do clube)

\footnotetext{
${ }^{51}$ Em "1914 os dados oficiais revelam que $77 \%$ da população do Estado de São Paulo era composta de brasileiros, mas que, entre eles, mais da metade era de filhos ou netos de europeus" (SEIXAS, Jacy Alves de. Mémoire et oubli..., cit., p. 19, tradução nossa).

${ }_{53}^{52}$ Para uma análise dessa questão, cf.: SIQUEIRA, Uassyr de. op. cit.

${ }^{53}$ Entrevista com o Sr. William João Sandonato, realizada em 23 de maio de 2010.
} 


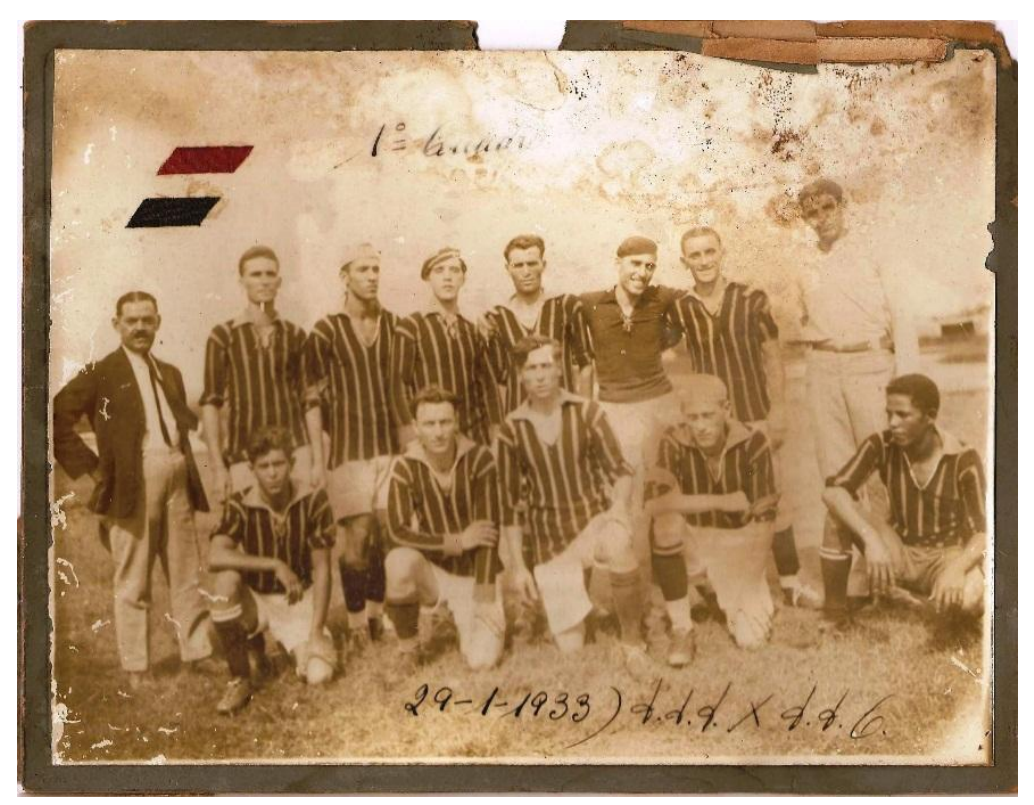

Figura 12 - Time principal do Anhanguera, 1933; partida contra Clube Garibaldi. (Fonte: Arquivo do clube)

Para compreender o comentário do veterano, é preciso levar em conta a importância dos associados para a receita do clube e a variedade de vínculos entre ítalo-brasileiros e negros na Barra Funda. Seus representantes mantiveram os mais diferentes vínculos pessoais e de trabalho na região. Além disso, foram corresponsáveis pela forma peculiar como o carnaval e o samba se estabeleceram no bairro. Para Margareth Rago, tratava-se

de um meio estratégico de valorização da cultura [negra], além de ser um importante canal de interação social, que durava muito além da própria festa carnavalesca, pois criava o motivo para que passassem todo o ano organizando festas e outras atividades destinadas a angariar fundos para seus blocos e cordões. $^{54}$

Revela-se aí que tanto o preconceito quanto a discriminação racial assumiam contornos específicos na cidade ${ }^{55}$ no que se refere aos dois elementos culturais. Nesse sentido, a identidade étnica dos ítalo-brasileiros - reunidos numa associação intitulada Anhanguera,

\footnotetext{
${ }^{54}$ RAGO, Margareth. A invenção do cotidiano na metrópole..., cit., p. 412. A esse respeito, cf. também: SIMSON, Olga Rodrigues de M. Carnaval em branco e negro: carnaval popular paulistano (1914-1988). São Paulo: Edusp; Imprensa Oficial do Estado de São Paulo, 2007; MORAES, José Geraldo Vinci de. Sonoridades paulistanas..., cit.

${ }^{55}$ Nela, como no Anhanguera, a questão é complexa. Em toda a trajetória do clube, apenas um negro alcançou a presidência: Sr. Salathiel da Silva, em meados dos anos 1950.
} 
não se deve esquecer - e de outras associações recreativas e esportivas só pode ser compreendida à luz das relações construídas nesses bairros varzeanos, considerando-se, ainda, que "a tendência à concentração nesses espaços foi tanto mais frequente quanto maior era a diferença entre uma determinada etnia e a população nacional. [...] os bairros étnicos representaram um fator de intimidade e segurança, em meio às vicissitudes da vida na cidade". 56

Essa busca por intimidade e segurança não significou, entretanto, nem homogeneidade, nem ausência de conflito no interior das microssociedades ali forjadas. A trajetória do clube evidencia que seus associados protagonizaram mais conflitos com outros ítalo-brasileiros do que com os demais grupos então presentes na região. ${ }^{57}$ Para William Sandonato, por exemplo, havia "mais rivalidade entre o Grajaú e o Anhanguera do que com os outros - que eram o Barra Funda e o Royal". 58

De todo modo, ainda que a maior parte dos associados do Anhanguera fosse proveniente de vínculos estreitos entre os moradores do bairro, a inadimplência não deixou de ser uma realidade para diretores e presidentes do período analisado. Em momentos diferentes da década de 1930, inúmeras foram as ações visando à redução do problema, como revelam as informações registradas na carteira do novo associado (figura 13) acerca do tipo de atividade que ele exercia no clube - o que modificava o valor de sua mensalidade - e do local onde se deveria cobrá-lo. Novas regras eram inventadas, mas, em verdade, apenas recaíam sobre aquelas já em vigor, denunciando certa ineficiência da dinâmica. Exemplo disso se entrevê em

\footnotetext{
${ }^{56}$ FAUSTO, Boris. Imigração..., cit., p. 31.

${ }^{57} \mathrm{O}$ que talvez tenha se alterado posteriormente, ao final dos anos 1930, em face do acirramento do fascismo e com a eclosão da Segunda Guerra Mundial, quando os ítalo-brasileiros eram identificados à Itália fascista, ao eixo. Os antigos associados do Anhanguera contam, por exemplo, que nesse período a Rua dos Italianos foi depredada e que o nome de sua placa foi trocado por Rua dos Brasileiros (entrevista com o Sr. Cirilo Magalhães, realizada em 12 de fevereiro de 2011).

${ }^{58}$ Como vimos, o Grajaú era o antigo Garibaldi, também fundado por ítalo-brasileiros no bairro do Bom Retiro. E, assim como o Clube Royal, o Clube Barra Funda foi fundado pela comunidade negra da Barra Funda de cima (entrevista com o Sr. William João Sandonato, realizada em 23 de maio de 2010).
} 
uma decisão encaminhada em assembleia: "ficou deliberado que as propostas deverão ser pagas no acto para serem acceitas". ${ }^{59}$ Assim, diante da assembleia, o proponente já deveria portar consigo o valor da joia e quiçá da primeira mensalidade do proposto.

Talvez a mais representativa dentre essas medidas de controle financeiro seja o processo que envolvia os pedidos de demissão realizados no clube. Tão frequentes quanto as propostas, ainda que em número muito menor, os pedidos de demissão só eram encaminhados quando, em primeiro lugar, os solicitantes "estivessem em dia com suas obrigações sociais" pecuniárias, mais precisamente - e as declarassem pessoalmente ou por escrito. Poucos eram os associados que conseguiam completar a primeira etapa de seu pedido de saída do clube. ${ }^{60}$ Talvez por essa razão, entre janeiro e junho de 1929, mesmo período em que houve 75 propostas de novos associados, os pedidos de demissão totalizaram somente 16 , sendo que a maioria deles procedia de diretores sociais e esportivos. Em face dos vários conflitos com os quais se envolviam na administração do clube, eles se demitiam dos cargos, ${ }^{61}$ mas não abandonavam sua condição de associado, sendo mais comum apenas trocarem de função. As demissões solicitadas no mês de setembro de 1929 transmitem uma ideia das dificuldades em se manter em algumas dessas funções: foram três pedidos de afastamento do cargo de cobrador, um do cargo de tesoureiro ${ }^{62}$ e apenas dois de sócios.

Mas, ainda que os cuidados fossem muitos e a inadimplência perdurasse no horizonte de preocupações do Anhanguera, a aceitação de novos associados não cessou de acontecer e de se ampliar. Entre 1928 e 1934, o clube incorporou por volta de 4 novos associados a cada

\footnotetext{
${ }^{59}$ Atas da Associação Atlética Anhanguera, 17 fev. 1930.

${ }^{60} \mathrm{E}$, dessa maneira, são também poucos os registros sobre as razões acerca do desejo de saída do clube.

${ }^{61}$ Alguns deles: tesoureiro, cobrador de mensalidades, mestre-sala, diretor social, diretor esportivo, secretário, diretor de pingue-pongue etc.

${ }^{62}$ Convocado pela diretoria a apresentar as razões para seu pedido de demissão do cargo de tesoureiro, o sócio Miguel Barbosa, em assembleia, enumera-as: "Primeiro que o Sr. Sabatini queria que seu filho dançasse pagando $1 \$ 000$ quando deveria pagar $2 \$ 000$. Segundo porque o Sr. Antonio Vignola ameaçou-o de aggredir a tapa [sic]" (Atas da Associação Atlética Anhanguera, 16 set. 1929).
} 
assembleia semanal, ${ }^{63}$ gerando uma média de no mínimo 16 novatos por mês e de 192 em um ano. ${ }^{64}$ À exceção de alguns interessados em atividades como a dança - como o rapaz da carteirinha reproduzida na figura 13 -, esse número traduzia fundamentalmente o interesse pelo futebol, e nada mais.

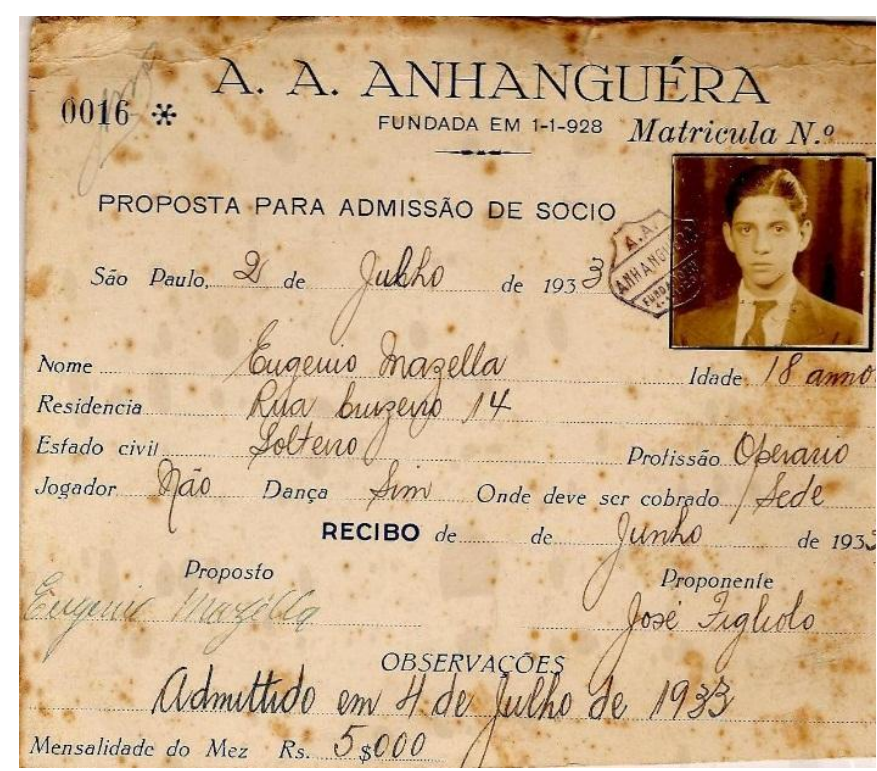

Figura 13 - Carteirinha de associado interessado na dança, 1933. (Fonte: Acervo do clube)

Como explica o Sr. Walter Dias: "uma coisa sempre existiu no clube. Tem dois tipos de pessoas que frequentam o clube. Tem aquele que vem exclusivamente pra jogar e não se interessa pela rotina, pelos eventos, o negócio dele é jogar. E tem aqueles outros que se engajam politicamente". ${ }^{65}$ A classificação do veterano - ele mesmo integrante de sucessivas diretorias do Anhanguera desde fins dos anos 1940, tal como seu pai, Antenor Dias, associado uma década antes - sugere que, desde o surgimento do clube, operava-se em seu interior uma específica divisão de interesses em torno do futebol. Vale a pena acompanhar como a questão se desenrolou naqueles momentos iniciais.

\footnotetext{
${ }^{63}$ Embora se tratasse de propostas, cujo aceite não está garantido, em todo o material pesquisado apenas um convidado não foi aceito. Infelizmente, as razões sobre a negativa não foram desenvolvidas na ata.

${ }^{64}$ Conforme os dados organizados no quadro de admissão de novos associados (anexo).

${ }^{65}$ Entrevista com o Sr. Walter Dias, realizada em parceria com Arthur Tirone em 22 de maio de 2009.
} 


\subsection{Saverio, Barthô e a dinâmica do futebol}

Quando ainda se encontrava na sede social situada à Rua do Córrego, o Anhanguera recebeu, em uma de suas assembleias, o Sr. Paulo Baddini, recém-associado e representante do Partido Democrático da Barra Funda. Ele vinha convidar o clube para atuar com seu $1^{\circ}$ quadro num jogo de futebol contra o Grupo Esportivo Carlos Gomes, no campo da Floresta. Tratava-se de integrar um festival organizado pelo partido que se realizaria dentro de poucos dias, no início de novembro de 1928. A princípio, os presentes se manifestaram contra a proposta, mas, "diante de tanta insistência do Sr. Baddini, o Sr. Presidente resolveu enviar uma comissão à sede do partido com o único fim de acceitarem o convite". ${ }^{66}$

A recusa inicial poderia indicar alguma rejeição ao jogo com o Carlos Gomes, não fosse o destaque dado ao fato de a comissão ser enviada com o único fim de aceitar o convite junto à sede do partido. A situação sugere, talvez, alguma animosidade por parte do clube em relação àquela entidade, uma vez que, em verdade, o Anhanguera já vinha tomando parte em campeonatos e festivais de futebol e de pingue-pongue promovidos por instituições dessa natureza. De todo modo, a questão não foi retomada após o aceite, prevalecendo apenas a discussão referente a quais associados deveriam atuar na partida, algo já suficientemente complexo, pois mesmo antes do convite o clube vivia impasses envolvendo seu principal selecionado de futebol.

A reunião que antecedeu a visita de Baddini, por exemplo, foi dedicada a discutir a suspensão do sócio fundador e jogador do $1^{\circ}$ quadro, Bartholomeu Maggi, que teria faltado ao último compromisso com seu clube para atuar em outro fora da capital. Por ser ele um dos mais antigos sócios e um dos fundadores do Anhanguera, a diretoria tomou sua falta como muito grave e, "visto que o Sr. Barthô se achava na sala de jogos [ao lado da sala de reuniões], o Sr. Presidente achou conveniente chamal-o para expor o motivo que o levou a

\footnotetext{
${ }^{66}$ Atas da Associação Atlética Anhanguera, 22 out. 1928.
} 
come[tê-la]". ${ }^{67}$ Barthô atendeu prontamente ao chamado e, diante da questão do Sr. Presidente, respondeu que,

se praticou semelhante acto, o qual não é de seu costume, foi justamente por ter dias antes discutido com o Sr. Saverio Russo, também jogador de nosso primeiro quadro de foot-ball, o qual promettera que, caso não actuasse no $1^{\circ}$ quadro, prepararia uma decepção no campo, decepção esta que [consistia em] tirar as camisas de foot-ball dos corpos de seus companheiros, entre outras criancices. ${ }^{68}$

Na sequência, ele complementou: "Se tal falta cometti [...] mereço as maiores das penas, mas scientes fiquem os Srs. Directores que se isso não fizesse, a promessa do Sr. Saverio seria cumprida no campo de foot-ball. Salveio-os de uma decepção". ${ }^{69}$

Mesmo utilizando argumentos que procuravam diminuir ou deslocar a importância da acusação que pesava sobre ele, Barthô não foi liberado das maiores penas. A diretoria resolveu suspendê-lo por trinta dias de qualquer dos quadros de futebol do clube - ele tinha o costume de jogar também no time juvenil -, embora permitisse sua circulação pelas dependências sociais. Após a resolução, entretanto, o Sr. Matheus Sabatini subitamente "usa da palavra" para dizer não apenas que Barthô contara a verdade sobre o Sr. Saverio, como também ele próprio possuía queixas contra o associado em questão, que teria tido "a ousadia de exigir os talões de recibo que achava em seu poder a fim de examinar se, de facto, os jogadores que iriam compor o primeiro quadro no próximo domingo estavam correntes em suas mensalidades". 70

Após essa declaração, outros diretores acabaram por se lembrar de problemas envolvendo Saverio, o que os fez convocá-lo para defender-se na reunião seguinte. Afora os notáveis recursos retóricos dos associados ali presentes, bem como a capacidade narrativa do secretário-escrivão Jeronymo Caetano, a repercussão em torno do caso de Barthô chama a

\footnotetext{
${ }^{67}$ Atas da Associação Atlética Anhanguera, 15 out. 1928.

${ }^{68}$ Ibid.

${ }^{69}$ Ibid.

${ }^{70}$ Ibid.
} 
atenção, assim como sua defesa diante da assembleia. O jogador utilizou argumentos muito parecidos com os da diretoria para tentar mostrar que também ele estava em defesa do Anhanguera. No entanto, para os presentes, sua atuação em outro clube falava por si. Por outro lado, Saverio vinha intervindo de maneira muito ativa - ou excessiva, conforme a visão de Sabatini - nas questões que envolviam o $1^{\circ}$ quadro de futebol, fosse na condição de jogador, fosse na de sócio-fundador, o que também chamou a atenção da diretoria.

A reunião seguinte ocorreria uma semana depois, em 22 de outubro, justamente a data da visita e do convite de Baddini para o jogo contra o Carlos Gomes, o que acrescentou cores ainda mais fortes à questão. Tão logo o representante do Partido Democrático deixou a sede do Anhanguera, Saverio deu início à sua defesa,

referindo-se ao Sr. Marciano Queiroz que, estando em atrazo nos cofres sociais, era escalado em todos os jogos que este club realizava, que era, portanto, um grave erro que comettia a nossa directoria pois não era justo ser elle substituído pelo Sr. Queiroz na actuação do primeiro quadro, enquanto esse não cumprisse com as suas obrigações. ${ }^{71}$

Quanto à discussão com Barthô, ele afirmou

ser exata, pois que elle, Saverio, era alvo da direcção esportiva toda vez que escalavam o primeiro quadro. Neste caso, já não se tratava de questão da sociedade, mas sim [...] desta direcção esportiva que aliás não poderá ser admissível menosprezando tão esforçado sócio e fundador para amparar forasteiros que aqui se alojam procurando impôr o profissionalismo para a provável decadência de nossa novel e progressiva sociedade. ${ }^{72}$

As críticas de Saverio especificamente dirigidas à direção esportiva criavam, assim, uma oposição entre o esforçado sócio-fundador, representante da sociedade, e a direção esportiva, que apoiava um forasteiro. O primeiro estaria ao lado da estabilidade do clube e o segundo, ao contrário, representaria sua decadência ao impor-lhe o profissionalismo. Note-se

\footnotetext{
${ }^{71}$ Atas da Associação Atlética Anhanguera, 22 out. 1928.

${ }^{72}$ Ibid.
} 
que a crítica se dirigia ao forasteiro - evidentemente, o Sr. Queiroz - e não ao sócio-fundador Barthô, muito possivelmente porque este já estivesse devidamente suspenso.

Diante da queixa de Saverio, o diretor Ezzio Marchetti disse "ser sufficiente [acertar] o débito do referido sócio e jogador para que o mesmo continuasse a participar como jogador do $1^{\text {o }}$ quadro". ${ }^{73}$ Ao que o sócio-fundador se adianta ressaltando que tal promessa já havia sido feita há tempos e nunca fora cumprida. Saverio não deixaria a reunião sem antes requerer uma nova e extraordinária assembleia geral na presença de "um certo número de sócios", ${ }^{74}$ no que foi atendido.

Barthô, por sua vez, solicitou, ainda na mesma reunião, a leitura de três cartas que trazia consigo. Na primeira, de próprio punho, ele "pedia mil desculpas e [também para] perdoarem a pena para [que ele] concorre[sse] no próximo festival [...] enfrentando o Carlos Gomes". 75 As outras continham " dois abaixos-assignados", sendo o primeiro de "seus collegas e admiradores e o seguinte [d]as gentis torcedoras", ${ }^{76}$ solicitando exatamente o mesmo.

"De nada valeram tais pedidos", 77 pois, para a diretoria presente, "as decisões resolvidas, quando justas, devem ser todas irrevogáveis". ${ }^{78}$ Em seguida, os diretores declararam que, para o jogo contra o Carlos Gomes em 4 de novembro, “os jogadores seriam transportados ao campo por meio de automóveis às [expensas] do clube", ${ }^{79}$ o que acentua a importância que a partida assumia na associação, sobretudo porque tais automóveis, num total

\footnotetext{
${ }^{73}$ Atas da Associação Atlética Anhanguera, 22 out. 1928.

${ }^{74}$ Ibid.

${ }^{75} \mathrm{Ibid}$

${ }^{76} \mathrm{Ibid}$.

${ }^{77} \mathrm{Ibid}$.

${ }^{78} \mathrm{Ibid}$

${ }^{79}$ Ibid.
} 
de quatro, seriam alugados a $20 \$ 000$ cada um, valor a ser "descontado do caixa" ${ }^{\$ 0}$ (o que, num rápido cálculo, representava a mensalidade de quase trinta sócios). ${ }^{81}$

E apesar de Saverio ter garantido que prevalecessem as regras da sociedade no caso de Barthô $^{82}$ e de Queiroz - e, com elas, a ausência desses dois jogadores no referido embate -, ele não alcançou mais que uma posição de reserva na escalação divulgada na assembleia extraordinária por ele solicitada.

Há que se destacar que Saverio foi atendido em sua solicitação por uma assembleia muito provavelmente em razão de sua condição de sócio-fundador. ${ }^{83}$ Seu trânsito na sede social e nas assembleias não era regulado da forma como acontecia a outros sócios, aos quais "não se deveria dar muita corda", segundo afirmou o Sr. Ezzio Marchetti. ${ }^{84}$ Esse foi o recurso para, uma vez mais, vincular suas condutas à defesa da sociedade, sabendo que a regularidade do pagamento das mensalidades dos jogadores era um tema caro a todos, mas sobretudo a diretores e presidente. Barthô, por sua vez, mobilizou associados e gentis associadas em seu pedido, o que evidenciou sua popularidade no clube e, quiçá, no bairro, tema ao qual retornaremos.

Embora uma série de motivações heterogêneas operasse nesse evento, uma delas já se torna aqui bastante evidente: Barthô e Saverio negociaram, até o último momento, sua participação no principal quadro de futebol do clube e, dessa maneira, no jogo contra o Carlos Gomes. Ambos sem sucesso, há que se repetir.

\footnotetext{
${ }^{80}$ Atas da Associação Atlética Anhanguera, 29 out. 1928

${ }^{81}$ Caso prevalecessem os $3 \$ 000$ citados. Na carteira do associado (figura 13), de 1933, nota-se que o valor passara aos $5 \$ 000$.

82 Embora novas cartas pela anistia de Barthô fossem lidas "com a máxima attenção de todos os directores" (Atas da Associação Atlética Anhanguera, 26 out. 1928).

${ }^{83} \mathrm{Em}$ outros momentos, ele também atuaria como diretor social.

${ }^{84} \mathrm{O}$ associado fez tal afirmação diante do pedido de alguns sócios para a realização de uma assembleia extraordinária, ainda que reconhecesse seu direito em fazê-lo (Atas da Associação Atlética Anhanguera, 5 nov. 1928).
} 
Da partida, sabe-se apenas que o assunto continuou repercutindo no Anhanguera. ${ }^{85} \mathrm{Na}$ reunião que se seguiu ao evento, os diretores se perguntavam sobre "as taças do jogo com o Carlos Gomes", ${ }^{86}$ pois Ezzio Marchetti estivera no clube rival e ouvira um de seus representantes dizer que "essa questão precisaria ser approvada perante o juiz do jogo e as palavras do Sr. Baddini". ${ }^{87}$ Diante de tal dado, o clube decide então "mandar uma carta para o Sr. Baddini dizendo-lhe [...] que o Anhanguera foi vencedor e [...] que foi dado o gôal válido pelo nosso adversário e pelos que tomaram parte no mesmo festival". ${ }^{88}$

Já os impasses acerca da participação no time principal não terminariam com a partida contra o Carlos Gomes. Ao contrário, eles se acentuariam no ano seguinte. Mal começara o calendário de jogos de futebol de 1929 e Saverio reiniciava seus trabalhos com questões à diretoria esportiva, sendo uma delas bastante direta: ele indagava se "estava ou não incluído no principal quadro de futebol" do clube ${ }^{89} \mathrm{O}$ diretor esportivo à época, Sr. Miguel Clemente, irritou-se com a intervenção do sócio-fundador e de Antonio Vignola, que, na condição de presidente, antecipou-se dizendo que Saverio entraria na equipe na ausência de certo jogador. Ao que Clemente imediatamente reagiu solicitando sua demissão da função de diretor esportivo.

Clemente é substituído pelo Sr. Delfim da Silva, que, recém-nomeado, vê-se envolvido num novo debate após realizar uma de suas primeiras escalações para o primeiro quadro de futebol. Diante dela, o Sr. Arsenio Gentil, então $2^{\circ}$ diretor esportivo, e os senhores Alberto Cassari e João Paris, respectivamente capitães do $1^{\circ}$ e do $2^{\circ}$ quadro, decidiram retirar

\footnotetext{
${ }^{85}$ Uma vez que seu resultado não foi registrado nem pela associação, nem pelos jornais, salvo se $A$ Gazeta Esportiva, recém-criada à época, tiver feito algum registro. Em nossa pesquisa, no entanto, o primeiro exemplar localizado do periódico data do final de novembro de 1928.

${ }^{86}$ Atas da Associação Atlética Anhanguera, 5 nov. 1928.

87 Ibid.

${ }^{88}$ Ibid., 12 nov. 1928.

${ }^{89}$ Ibid., 21 jan. 1929.
} 
“a mesma do lugar em que estava exposta, colocando outra em sua substituição". ${ }^{90}$ Por esse ato, Gentil e os capitães foram convidados a se defender em assembleia. $\mathrm{O} 2^{\circ}$ diretor esportivo expõe sua defesa dizendo que: "em conformidade com os estatutos da sociedade, a escalação do quadro de futebol é feita na presença dos [...] capitães do $1^{\circ}$. e $2^{\circ}$. quadros e que o $\mathrm{Sr}$. Delphim da Silva não seguia os estatutos, fazendo a escalação a sós e sem consultar os capitães". ${ }^{91}$ Gentil acrescentou:

os jogadores não estavam satisfeitos com a escalação feita, exigindo a retirada do Sr. Saverio Russo e pondo em seu lugar o Sr. Bartholomeu Maggi. Em vista disso, forçado por essas circunstâncias [...], ele retirou a escalação [em que constava o nome de] Saverio Russo, substituindo-o de accordo com o desejo unânime dos outros jogadores pelo Sr. Bartholomeu Maggi. ${ }^{92}$

Nota-se que Saverio havia trabalhado também junto ao novo diretor esportivo, pois este infringira a regra procurando, talvez, garantir a escalação do primeiro. A infração parece ter sido percebido pela comunidade esportiva que reagiu de maneira vigorosa, evidenciando que o ato de Delfim não correspondia ao esperado. $O$ incidente foi encerrado com a transferência de Saverio do $1^{\circ}$ para o $2^{\circ}$ quadro de futebol e com o envio de uma carta ao Sr. Delfim solicitando explicações sobre o ocorrido. As assembleias seguintes não voltaram a comentar o caso.

Em abril de 1929, no entanto, o tema retorna e começa a assumir contornos mais definidos. Silva é novamente convidado a comparecer a uma das assembleias em que se questionava o critério da escalação de jogadores para o time principal. Ele então se manifesta “dizendo que sendo director esportivo não quer saber se os jogadores pagam ou não a mensalidade, que o que ele quer é ver bom quadro em campo". ${ }^{93}$ Delfim modificava sua conduta em relação ao episódio anterior e, com seus argumentos, explicitava enfim em que

\footnotetext{
${ }^{90}$ Ibid., 2 fev. 1929.

${ }^{91}$ Atas da Associação Atlética Anhanguera, 2 fev. 1929.

${ }^{92}$ Ibid.

${ }^{93}$ Ibid., 29 abr. 1929.
} 
consistiam as tensões em torno do futebol no clube. A questão, já esboçada pelos diretores esportivos anteriores, foi recebida como um tema a ser discutido, de maneira exclusiva, em uma assembleia extraordinária. Mas, ainda que a reunião tenha efetivamente se realizado no dia 2 de maio, ela acabou sendo dedicada apenas à organização de mais um baile familiar e o tema não voltaria a pautar, de maneira tão incisiva, as assembleias da associação.

De todo modo, a fala de Delfim apresentara elementos novos ao debate, por se basear, em primeiro lugar, na defesa de sua autonomia em relação ao que se passava na sociedade como um todo. Ele também afirmava sua autoridade como diretor esportivo, por reconhecer o que seria um bom quadro de futebol, um saber que ele já demonstrava aplicar na escalação de seus jogadores. Era exatamente nesse tipo de critério - meritocrático, por assim dizer, ao se fundar exclusivamente no desempenho esportivo -, em pleno vigor numa série de associações esportivas, que residiam os questionamentos de Saverio. Sempre em dia com os valores da sociedade e com a análise das carteiras dos sócio-jogadores, o sócio-fundador parecia não aceitar tal flexibilização em relação às normas do clube, sobretudo no que se referia ao $1^{\circ}$ quadro de futebol, o centro de suas atenções. Ao mesmo tempo, seus companheiros começavam a notar outras razões para as preocupações do colega com os representantes do time principal, pois Saverio "só reclama[va] quando não era escalado", 94 o que sugere certa ambiguidade no comportamento do sócio-fundador. Para compreendê-la, parece necessário passar de Saverio e da sociedade para outros atores, especificamente para os sócio-jogadores, personagens centrais nesse impasse.

Assim chamados desde as primeiras assembleias (sugerindo que a categoria fosse corrente mesmo antes do surgimento do clube) por se interessarem apenas pelo futebol, os sócio-jogadores contrastavam com os sócios, mais vinculados às coisas do clube, como explicitara antes o Sr. Walter Dias. Representados por diretoria, presidência e uns poucos

\footnotetext{
${ }^{94}$ Atas da Associação Atlética Anhanguera, 29 abr. 1929.
} 
indivíduos de outros segmentos, os sócios possuíam vínculos diferenciados entre si e com o clube ao trabalharem cotidianamente em sua organização. Por essa razão, os sócio-jogadores, cuja ligação com a entidade era, em geral, restrita aos fins de semana, figuravam como um tema de menor importância nas assembleias. Eram citados somente nos momentos em que desrespeitavam as regras do clube por inadimplência, por comportamento inadequado ou por atuarem em times de futebol de outros clubes, sendo esta a principal delas. À atuação em defesa de outras cores respondia-se rapidamente - e sem alarde - com a suspensão do transgressor, em trinta ou sessenta dias, e, em alguns casos, até mesmo com sua eliminação da sociedade. A questão assumia, entretanto, proporções diferentes caso o sócio-jogador acumulasse outra função no clube.

É o que se nota a partir do caso de Joaquim Seixas. Proposto em janeiro de 1929 por Antonio Satriani, o jogador foi suspenso, meses depois, "por dois jogos por ter ido defender outras côres". ${ }^{95}$ Tal como aconteceu a Barthô, sua falta foi considerada grave e, além da suspensão, solicitou-se o comparecimento do associado à reunião semanal. A ata subsequente registra suas explicações na seção nomeada Demissões: “o Sr. Joaquim Seixas communica à direcção esportiva que não pode, até segunda ordem, fazer parte do quadro de futebol por ser obrigado a jogar pela casa em que trabalha". ${ }^{96}$

Nenhum comentário foi registrado após o comunicado, sugerindo, talvez, a compreensão consensual da diretoria em face da situação que àquela altura já não era incomum na várzea. A prática concomitante do futebol em uma associação atlética e em clubes de fábrica ou de casas comerciais tornara-se corrente à época, conforme revela Antunes:

com o surgimento dos primeiros clubes ligados a fábricas, o critério para a admissão de empregados sofreu alterações. Passou-se a preferir não apenas o

\footnotetext{
${ }^{95}$ Atas da Associação Atlética Anhanguera, 22 out. 1929.

${ }^{96}$ Ibid., 11 nov. 1929.
} 
bom profissional, mas aquele que também jogasse bem o futebol [o que] possibilitou que operários conseguissem melhores empregos, ou, então, complementassem seu salário através do "bicho".

Seixas permaneceu no clube por quase um mês antes de solicitar verbalmente sua demissão do cargo de sócio-diretor. O pedido foi aceito pela maioria dos diretores do clube, à exceção dos esportivos, entre eles o Sr. Delfim da Silva. Embora suas razões não tenham sido registradas, não é difícil imaginar que Silva atuasse em acordo com os princípios que apresentara em abril, sobretudo se considerarmos que Seixas fosse um bom jogador, o que é sugerido tanto pela exigência de exclusividade feita pela casa em que trabalhava, quanto pela punição recebida: uma suspensão por apenas dois jogos.

Embora estivesse longe de ser o único episódio dessa natureza no Anhanguera, o caso de Seixas recebeu de fato maior atenção, pois sendo também diretor do clube, ele não poderia representar junto aos demais a possibilidade de atuar por outra associação, colocando em xeque a organicidade da administração ao romper com valores ali tão reificados como a fidelidade ao clube. Se sobre a diretoria e a presidência pesava a imagem da sociedade, cabia a seus representantes zelar por ela. Daí, por exemplo, o controle interno e regulamentar sobre o que se dizia sobre o clube. Após a ocorrência de difamações e boatos sobre o Anhanguera e seus dirigentes, uma assembleia de 1931 assim delibera: "será chamado o sócio que em lugar público discutir sobre assumptos da sociedade [caluniando] nomes de diretores sem razão de ser ou difama[ndo] a sociedade. O director ou sócio que assim proceder será suspenso conforme a gravidade do caso", ${ }^{98}$

\footnotetext{
${ }^{97}$ ANTUNES, Fátima M. R. Ferreira. Futebol de fábrica em São Paulo, cit., p. 170. Nas palavras de Franco Júnior: "O profissionalismo dissimulado (ou amadorismo marrom) praticado desde a década de 1910 alimentavase das bilheterias e dos ricos patronos dos clubes. Cada vez era mais freqüente os jogadores receberem uma premiação, desde 1923 chamada de 'bicho' [...] [porque] os comerciantes portugueses torcedores do Vasco recompensavam com uma vaca inteira as vitórias sobre o América [...] enquanto derrotar o Flamengo [...] valia uma vaca de três pernas" (A dança dos deuses..., cit., p. 72).

${ }^{98}$ Atas da Associação Atlética Anhanguera, 28 set. 1931.
} 
É diante dessa dinâmica que se pode compreender por que os casos de sóciojogadores comuns não alcançavam grande repercussão no clube e, assim, ainda que suas punições fossem registradas, poucos eram os detalhes oferecidos nas atas sobre as motivações para defender outros clubes. É possível, no entanto, aproximar-se desse universo por outras vias. Em um curto período do ano de 1931, por exemplo, as propostas da associação continham informações sobre a profissão, a idade e o estado civil dos propostos:

\begin{tabular}{|c|c|c|c|c|c|c|}
\hline \multicolumn{7}{|c|}{1931} \\
\hline Data & Proposto & Idade & Profissão & $\begin{array}{l}\text { Estado } \\
\text { civil }\end{array}$ & Endereço & Proponente \\
\hline \multirow{5}{*}{ 05/01 } & Camillo dos Santos & 23 & Pintor & - & Rua Inhaúma & Antônio T. Carvalho \\
\hline & João Gomes & 24 & Marceneiro & - & Rua Inhaúma & Antônio T. Carvalho \\
\hline & Eduardo dos Santos & 23 & - & - & Rua Inhaúma & Antônio T. Carvalho \\
\hline & José Cardoni & 18 & Açougueiro & - & Rua Piahy & Armando A. \\
\hline & Carlos Medeiros & 18 & Comércio & - & Rua Boracéa, 28 & José Monteiro \\
\hline \multirow{4}{*}{$12 / 01$} & Nelson Gamboa & 18 & Comércio & - & Rua Salta-Salta, 14 & Carlos Medeiros \\
\hline & Oswaldo Mauro Giglio & 27 & Graphico & - & Rua Anhaia, 45 & Antonio Althieri \\
\hline & Manoel da Silva & 19 & Padeiro & - & Rua Anhanguera, 143 & Paulo de Lima \\
\hline & Sauti Poffo & 43 & Barbeiro & - & Rua Anhanguera, 35 & Antonio Vignola \\
\hline \multirow{9}{*}{$19 / 01$} & Remo Marinelli & 20 & Marceneiro & - & Rua Casa Verde, 25 & Antonio T. Carvalho \\
\hline & Octavio Pareschi & 19 & Barbeiro & - & Rua Victorino Camillo, 17 & Antonio T. Carvalho \\
\hline & Marino Pacheco & 19 & Pintor & - & Rua Inhaúma, 15 & Antonio T. Carvalho \\
\hline & Joaquim dos Santos & 26 & Padeiro & - & Rua Baixa, 2 & Miguel S. Ferreira \\
\hline & José Dias Gomes & 19 & Padeiro & - & Rua Baixa, 2 & Miguel S. Ferreira \\
\hline & Manoel Borges de Lima & 22 & Padeiro & - & Rua Anhanguera, 5 & Miguel S. Ferreira \\
\hline & José de Mazzi & 23 & Marceneiro & - & Rua Cruzeiro & Fernando Fuzer \\
\hline & Rolando Medeiros & 18 & Comércio & - & Rua Anhanguera, 137 & Duarte Medeiros \\
\hline & Elydio S. & 19 & Marceneiro & - & Rua Anhanguera, 167 & Duarte Medeiros \\
\hline \multirow{7}{*}{$26 / 01$} & Arlindo Chicão & 20 & Serralheiro & - & Rua Anhaia, 59 & José Menzani \\
\hline & Geraldo Marasco & 18 & - & - & Rua Cruzeiro & Duarte Medeiros \\
\hline & Vicente Virgínio & 20 & - & - & Rua Anhanguera & Ezzio Marchetti \\
\hline & Waldomiro dos Santos & 18 & - & - & Rua Lucilla, 24 & Oswaldo Medeiros \\
\hline & Domingos F. & 22 & - & - & Rua Rudge & Paulo de Lima \\
\hline & Armenio dos Santos & 28 & - & - & Rua Sergio Thomaz & Ezzio Marchetti \\
\hline & Albino Pereira dos Santos & - & - & - & Rua Albuquerque Lins, 152 & Arthur Lopes de Almeida \\
\hline \multirow{4}{*}{$02 / 02$} & Negro Guido & - & - & - & Rua do Bosque, 69 & Duarte de Mattos \\
\hline & Eduardo Cinquini & - & - & - & Rua Anhanguera, 26 & $\begin{array}{l}\text { Fez a proposta diretamente na } \\
\text { secretaria. }\end{array}$ \\
\hline & Antonio Barone & - & - & - & Rua do Bosque, 162 & Jeronymo Caetano \\
\hline & Antonio Cirolli & - & - & - & Rua do Bosque & João do Valle \\
\hline \multirow{3}{*}{$09 / 02$} & Luiz Ramos & 20 & - & - & Rua Pedro Vicente, 60 & Germano Bindo \\
\hline & Antonio Pires & 22 & - & - & Avenida Cantareira & Germano Bindo \\
\hline & Ricieri Corsato & 23 & - & - & Rua do Bosque & Jeronymo Caetano \\
\hline \multirow{4}{*}{$24 / 02$} & David Bastos & 23 & Padeiro & - & Rua das Palmeiras, 41 & Eduardo Faria \\
\hline & Arthur Cardoso de Sá & 27 & Padeiro & casado & Rua das Palmeiras, 41 & Eduardo Faria \\
\hline & Hilário D. Motta & 23 & - & - & Rua das Palmeiras, 41 & $\begin{array}{l}\text { Fez a proposta diretamente na } \\
\text { secretaria. }\end{array}$ \\
\hline & Joaquim Cardoso & 22 & Marceneiro & - & Rua Cruzeiro, 120 & Domingos Lemonte \\
\hline \multirow{2}{*}{$02 / 03$} & Edson Lacerda & 18 & Estudante & - & Rua Baronesa de Porto Carreiro, 1 & Antonio Teixeira de Carvalho \\
\hline & Oswaldo Correa & 19 & Comércio & - & Rua Baronesa de Porto Carreiro, 8 & Antonio Teixeira de Carvalho \\
\hline
\end{tabular}




\begin{tabular}{|c|c|c|c|c|c|c|}
\hline & José Seixas & 25 & Comércio & - & Pça Marechal Deodoro, 34 & Arthur Lopes de Almeida \\
\hline & Reinaldo Lima & 22 & Entalhador & - & Rua Cruzeiro, 78 & Armando Lima \\
\hline \multirow{7}{*}{ 16/03 } & José Soares & 22 & Comércio & - & Rua Albuquerque Lins, 152 & Miguel Ferreira \\
\hline & Graciliano G. & 30 & Lustrador & - & Rua Anhanguera, 46 & Ezzio Marchetii \\
\hline & Joaquim de Jesus & 22 & Padeiro & solteiro & Avenida São João, 129b & Arthur Lopes \\
\hline & Carlos B. S. & 19 & Estudante & solteiro & Rua Anhanguera, 4 & João Bellis \\
\hline & Cesar Rosa & 20 & - & solteiro & Avenida Rudge, 136 & Antonio Teixeira de Carvalho \\
\hline & Mario da Silva Reis & 25 & Comércio & - & Rua Albuquerque Lins, 152 & José Soares \\
\hline & Victorio Mendes & 20 & Ladrilheiro & - & Rua Martins Buchard, 1 & Miguel Marasco \\
\hline \multirow{8}{*}{$23 / 03$} & José Cestari & 19 & Tipógrafo & solteiro & Rua Souza Lima, 83 & Henrique Clemente \\
\hline & José V. Galanti & 25 & Pedreiro & casado & Rua Anhanguera, 57 & Alfredo Chiochetti \\
\hline & Antonio Marques & 24 & $\begin{array}{l}\text { Comerciant } \\
\mathrm{e}\end{array}$ & solteiro & Rua Cruzeiro, 121 & Joaquim Cardoso \\
\hline & João H. da Costa & 29 & padeiro & solteiro & Alameda Glete, 49 & Miguel S. Ferreira \\
\hline & Herculano Marques & 22 & comerciante & solteiro & Rua Albuquerque Lins, 152 & Mario Silva Reis \\
\hline & Pedro Vagiani & 30 & comerciante & solteiro & Rua Lopes de Oliveira, 26 & João Salles \\
\hline & Antonio Silva dos Santos & 19 & padeiro & solteiro & Rua Anhanguera, 66 & Arthur de Almeida \\
\hline & José Mendonça & 19 & comerciante & solteiro & Rua Solimões, 12 & R. Minelli \\
\hline \multirow{4}{*}{$30 / 03$} & Irineu de Moura & 18 & encanador & solteiro & Rua Augusta & Bartholomeu Maggi \\
\hline & Alberto Ramos & 18 & estudante & solteiro & Rua dos Andradas, 25 & Edson Amazonas \\
\hline & José Alves da Silva & 28 & padeiro & - & Rua Cruzeiro, 113 & Maximiliano Pires \\
\hline & Joaquim dos Santos & 42 & carpinteiro & casado & Rua Cruzeiro & Anselmo Gentil \\
\hline \multirow{3}{*}{$13 / 04$} & Casemiro M. & 27 & mecânico & - & Rua Cruzeiro, 104 & Vicente L. \\
\hline & Joaquim Coutinho & 22 & padeiro & solteiro & Rua Anhanguera, 13 & Arthur Lopes de Almeida \\
\hline & Arthur Pereira & 20 & padeiro & solteiro & Rua Solimões, 17 & José Soares \\
\hline \multirow{3}{*}{$27 / 04$} & Luiz Porreta & & comerciante & solteiro & Rua Eduardo Chaves & Antonio Biaggio \\
\hline & Antonio d'Abril & 22 & comércio & solteiro & Avenida Angélica, 90 & Anselmo Gentil \\
\hline & João d'Abril & 20 & comércio & solteiro & Avenida Angélica, 90 & Anselmo Gentil \\
\hline \multirow{4}{*}{$18 / 05$} & Antonio Hirashavitz & 23 & mecânico & solteiro & Rua do Bosque, 25 & - \\
\hline & Ricardo Forli & 24 & comércio & solteiro & Rua Capitão Matarazzo, 162 & Augusto Casalli \\
\hline & Aldo Capelli & 20 & pintor & solteiro & Rua Casa Verde, 22 & João Faria \\
\hline & Carlos Fernandes & 20 & fundidor & solteiro & Rua S.[?], 73 & João Faria \\
\hline \multirow{7}{*}{$26 / 05$} & Henrique Batispta & 22 & padeiro & solteiro & Avenida São João, 190 & Joaquim Jesus \\
\hline & Antonio Gonçalves & 24 & padeiro & solteiro & Avenida Marquês de Itu, 52 & Antonio da Silva Santos \\
\hline & Ettore Sinelli & 21 & chauffer & solteiro & Rua Coronel Cintra, 21 & Casemiro M. \\
\hline & Leopoldo Coutinho & 22 & comerciante & solteiro & Rua Barra do Tibagy, 72 & Alvaro Pereira \\
\hline & Constantino T. & 20 & mecânico & solteiro & Rua Coronel Cintra, 27 & - \\
\hline & Lourenço Fernandes & 25 & padeiro & solteiro & Rua Albuquerque Lins, 152 & M. Souza \\
\hline & Gilberto Lage & 19 & padeiro & solteiro & Rua Voluntários da Pátria, 241 & Arthur Lopes de Almeida \\
\hline $01 / 06$ & Belmiro de Almeida & 26 & comerciante & - & Rua Albuquerque Lins, 152 & José Soares \\
\hline \multirow{3}{*}{$08 / 06$} & Mercantonio & 18 & açougueiro & solteiro & Rua Souza Lima, & João Paris \\
\hline & Maximiliano Branco & 22 & comércio & - & - & Manoel de Mello \\
\hline & Alexandre Martins & 21 & mecânico & solteiro & Rua Anhaia, 52 & Ezzio Marchetti \\
\hline \multirow{2}{*}{$16 / 06$} & Miguel Rasuko & 23 & chauffer & solteiro & Rua Baronesa do Porto Carreiro, 17 & - \\
\hline & Edewigs Antonio Marques & 21 & comércio & solteiro & - & Aldo Capelli \\
\hline \multirow{2}{*}{$26 / 06$} & Luiz Taricone & 19 & - & solteiro & Rua Julio Conceição, 109 & Octavio Pareschi \\
\hline & João Ferreira & 24 & impressor & solteiro & Rua Jaraguá, 46 & Ezzio Marchetti \\
\hline $29 / 06$ & Eduardo de Souza & 22 & comércio & solteiro & - & Antonio Satriano \\
\hline
\end{tabular}


Afora a frequência de certos endereços, ${ }^{99}$ o que mais chama a atenção nessa amostra é a juventude dos novos sócios, somada ao fato de que eles eram, em sua maioria, solteiros e trabalhadores do comércio. É a partir de tal perfil que melhor se compreende um comentário do veterano Cirilo Magalhães, ex-sócio-jogador do Anhanguera, em relação às suas motivações: "a gente era associado a mais de um clube para ter jogo todo sábado e domingo". ${ }^{100} \mathrm{~A}$ informação é preciosa, pois revela que havia sócio-jogadores ligados a mais de uma associação não apenas em razão de seus trabalhos em fábricas e casas comerciais com times exclusivos de futebol, mas devido ao desejo de jogar. Tal dinâmica era bastante semelhante ao que se passava nas associações recreativas voltadas para a dança, nas quais também havia grande circulação de sócios vinculados a mais de um clube. O mesmo acontecia nos grêmios voltados ao teatro, cujos membros "não participam exclusivamente de uma só trupe, mas, ao contrário, figuram em geral no elenco de várias ao mesmo tempo". ${ }^{101}$

Não se pode esquecer que uma pluralidade de associações recreativas e até mesmo sindicais fornecia aos varzeanos "um amplo leque de possibilidades para o uso de seu tempo livre", ${ }^{102}$ possibilitando a alguns indivíduos fazerem parte de diferentes tipos de associação, muitas vezes de maneira concomitante. O corajoso diretor esportivo Delfim da Silva conhecia bem esse sistema, pois, ao que parece, chegara ao Anhanguera justamente devido ao interesse por seus bailes.

No que se refere especificamente ao futebol, tal dinâmica não parecia representar novidade entre os clubes varzeanos. Décadas antes, jogadores do Bom Retiro praticavam futebol, ao mesmo tempo, no Sport Club Corinthians Paulista e na A. A. Botafogo, da qual,

\footnotetext{
99 Que, somados aos demais recolhidos em outros anos, podem vir a compor um detalhado quadro analítico sobre os associados do Anhanguera.

${ }^{100}$ Entrevista com o Sr. Cirilo Magalhães, realizada em 12 de fevereiro de 2011. Cirilo integrou os principais quadros do clube já em meados dos anos 1940.

${ }_{101}^{101}$ SCHPUN, Mônica Raisa. O cinema mudo em São Paulo..., cit., p.4.

${ }^{102}$ SIQUEIRA, Uassyr de. Clubes recreativos..., cit., p. 304.
} 
aliás, teriam saído os idealizadores do clube alvinegro. ${ }^{103}$ Isso parecia ocorrer também com os chamados clubes de elite, cuja circulação de jogadores despertou a atenção do pesquisador Plínio Negreiros:

como e por que vários jogadores trocavam constantemente de clubes? Quais eram os mecanismos utilizados pelos dirigentes para que bons atletas viessem a defender as cores de um novo clube, uma vez que neles se defendia um esporte "eminentemente amador", cujos ganhos eram físicos e morais, jamais pecuniários? ${ }^{104}$

Tratava-se, pois, de uma prática estabelecida mesmo antes da característica movimentação no período profissional do futebol, iniciado oficialmente em 1933. Para Negreiros, a chamada "cavação - ato de atrair esportistas para um determinado clube" 105 - já definia uma espécie de semiprofissionalismo que beneficiava os bons jogadores com pequenas vantagens. Embora não fossem "diretamente remunerados pela prática do futebol [estes] teriam um emprego, no qual talvez não precisassem trabalhar muito, se de fato trabalhassem". 106

No caso do Anhanguera, afora a possibilidade de reunir ganhos extras pela participação nos quadros futebolísticos de fábricas ou casas comerciais, ${ }^{107}$ outro elemento talvez vigorasse nesse desejo de jogar todo sábado e domingo: "se era pra jogar, ia pra jogar mesmo. No festival, por exemplo, lotava. No festival [...] jogavam vários clubes. Era um torneio num dia só, num sábado ou domingo. Lotava de torcida, todo mundo ia ver, todo mundo ia participar porque era uma diversão". ${ }^{108}$ Não parecia desprezível aos sócio-jogadores a possibilidade de protagonizar tais experiências coletivas, que em alguns casos reuniam

\footnotetext{
${ }^{103}$ Para Plínio Negreiros, era justamente essa prática que revelava a ligação do clube com a várzea, indicando que a circulação de jogadores constituía um traço característico daquele espaço (Resistência e rendição..., cit., p. 72).

${ }^{104}$ Resistência e rendição..., cit., p. 46.

${ }^{105}$ Ibid., p. 48.

${ }^{106}$ Ibid.

${ }^{107}$ Embora não existam referências de que jogadores do Anhanguera tenham integrado o amadorismo marrom dos clubes de elite, o processo chegara até a várzea.

${ }^{108}$ Entrevista com o Sr. Cirilo Magalhães, realizada em 12 de fevereiro de 2011.
} 
milhares de pessoas. ${ }^{109}$ Há que se imaginar o impacto de tornar-se conhecido por meio do futebol para “operários pobres, outros tão pobres que nem operários eram [e] para os negros quando jogavam nos times dos brancos". 110

Daí que valia pagar, ainda que de maneira ocasional, pelos recibos das entidades esportivas às quais eles eventualmente se vinculassem, ou ficar sob ameaça de suspensões ou eliminações em face da múltipla associação ou mesmo da simples atuação em outro time. Alguns encaminhamentos pareciam possíveis aos jogadores quando tal situação se efetivava, conforme revela o pedido do Sr. Afonso Lollito, apresentado numa carta:

Venho por meio desta pedir que a directoria me perdoe por eu ter feito um papel muito feio. Eu mesmo reconheço que procedi muito mal, foi um acto de fracheza minha por ter deixado de defender as cores da agremiação. Se quiserem me perdoar, podem contar comigo de domingo em diante. ${ }^{111^{3}}$

Além de Lollito e outros que apresentavam argumentos em tom de confissão religiosa, havia também aqueles que, prevenidos, procuravam negociar com o Anhanguera eventuais participações em outros clubes, como demonstra o seguinte registro de dezembro de 1930:

O sr. João Cavalheiro pede permissão para no próximo dia $1^{\circ}$ de janeiro de 1931 jogar contra as cores do clube no jogo Anhanguera X Garibaldi quando irá jogar para o Garibaldi de onde também é sócio. Como o Sr. João Cavalheiro não é jogador, digo, não consta como jogador, foi concedida a licença pedida. ${ }^{112}$

Outro recurso era utilizado pela maioria dos sócio-jogadores a fim de evitar a configuração desfavorável de não comparecer a um dos jogos para o qual se estava escalado, circunstância entrevista pelas punições aplicadas no Anhanguera: "Deliberou-se suspender por 3 jogos de futebol o Francisco [?] por não comparecer quando estava escalado: o Sr. Cesar

\footnotetext{
${ }^{109}$ Em reportagem sobre uma partida protagonizada pelo Carlos Gomes em outubro de 1931, A Gazeta Esportiva estimou que a assistência totalizasse 4.000 pessoas (A Gazeta Esportiva, 3 out. 1931).

${ }^{110}$ SEABRA, Odette Carvalho de Lima. Urbanização e fragmentação..., cit., p. 356.

111 Atas da Associação Atlética Anhanguera, 17 ago. 1931.

112 Ibid., 28 dez. 1931.
} 
Belloni 3 jogos de futebol também por não comparecer quando estava escalado”, 15 dias de sede-campo o Sr. Antonio Victorino". 113

Em tais situações estavam envolvidos principalmente aqueles de reconhecido desempenho futebolístico, e era justamente para eles que todos esses riscos pareciam menores diante da popularidade que adquiriam por sua atuação nos clubes do bairro. Não se pode esquecer que, nesse momento, a imprensa já realizava ampla divulgação dos eventos varzeanos, ampliando a escala das experiências esportivas que colocavam jovens jogadores como representantes de "uma nova identidade e de um novo estilo de vida". ${ }^{114}$

Esse era o caso de Barthô, que não só reconhecia sua fama junto à comunidade, como dela vinha usufruindo em variadas situações. Talvez por essa razão ele adotasse postura tão diferente da de Saverio no Anhanguera. Embora ambos o tivessem fundado, Barthô agia como mais um dos sócio-jogadores, reunindo diversão e pequenos lucros em seu futebol. Possivelmente daí vinha também sua identificação com o time juvenil do Anhanguera, ao qual insistia em manter-se vinculado, a despeito das reclamações de Saverio. Já este, ao contrário, figurava praticamente como um presidente emérito da sociedade: zelava por seus estatutos, suas regras e seus valores, envolvendo-se em constantes conflitos com os sócio-jogadores ao procurar submetê-los a tal funcionamento.

As posições e os embates entre os sócio-fundadores sintetizam algumas das tensões que marcaram a forma como o futebol estava sendo vivido pelos mais diversos segmentos do Anhanguera e mesmo por alguns de seus sujeitos. Esse impasses não estavam, entretanto, desvinculados do que se passava na cidade com um todo e na várzea, em particular. No que se refere especificamente ao futebol, há que se considerar a série de transformações advindas da progressiva entrada dos populares nos meios oficiais, a remuneração de jogadores - o que,

\footnotetext{
${ }^{113}$ Ibid., 28 out. 1931.

${ }^{114}$ SEVCENKO, Nicolau. Orfeu extático na metrópole..., cit., p. 34.
} 
para alguns, já representava os primeiros passos rumos à profissionalização do esporte - e a formação da imprensa esportiva. Diante dessas questões, certas associações se esforçaram para manter distantes de seu cotidiano alguns dos conteúdos trazidos pelo futebol, caso de um importante clube nascido em meio à elite de São Paulo.

\subsection{A Associação Atlética Anhanguera e o Clube Atlético Paulistano: semelhanças entre o futebol de várzea e o de elite?}

De maneira semelhante ao Anhanguera, o Clube Atlético Paulistano reuniu algumas das principais tensões presentes no futebol entre o fim dos anos 1920 e o início da nova década. Em primeiro lugar, isso se deu por ser ele o clube mais estreitamente relacionado à representação da elite paulistana. No clássico trabalho de Anatol Rosenfeld, ${ }^{115}$ por exemplo, o Paulistano figura como o par oposto do futebol de várzea devido à constante evocação de seu ethos aristocrático. Esse traço é assumido pelo próprio clube, em vários momentos de sua história:

Havia uma coisa em que o Paulistano era imbatível: reunir gente bonita, elegante, os que contavam e comandavam a cidade, o estado, o país. [Lá] se encontravam o mundo financeiro, a elite cafeeira, os formadores de opinião. Embora houvesse garden parties em todos os clubes, as que recebiam maior atenção da imprensa eram as do Paulistano. ${ }^{116}$

O texto citado, de autoria de Ignácio de Loyola Brandão, reitera essa imagem, cem anos depois, e também o fato, insistentemente destacado, de se tratar do clube que melhor campanha fazia de suas qualidades. Assim construídos, tais elementos tornavam sua vivência em relação ao esporte muito diferente do que se passava na várzea. No entanto, além de dividirem os campos de futebol na Várzea do Carmo, outras experiências em muito aproximaram seus universos. Vale a pena acompanhar algumas delas.

\footnotetext{
115 Negro, macumba e futebol. São Paulo: Perspectiva, 2000.

${ }^{116}$ CLUB ATHLETICO PAULISTANO. Corpo e alma de um clube centenário. São Paulo: DBA, 2000, p. 27.
} 
Fundado em novembro de 1900 na Rotisserie Sportsman, à Rua São Bento, região central da cidade, por Ibanez Salles, Bento Bueno, os irmãos e primos Costa Marques e Mário Cardim, ${ }^{117}$ entre outros jovens representantes da sociedade cafeicultora paulistana, o clube Paulistano surge como o primeiro da cidade a ser formado só por brasileiros, ${ }^{118}$ característica esta também reivindicada pelo Mackenzie. Vinculado ao poder da família $\operatorname{Prado}^{119}$ desde o início, o clube figurou como uma das entidades esportivas que mais exerceram influência sobre o futebol até os anos 1930, tanto pelos resultados de suas partidas, quanto por ditar as bases do que seria o sportmanship. ${ }^{120}$ Tamanho destaque pode ser compreendido pela forma como realizava a incorporação de novos sócios: o clube só aceitava "os que, sendo público e notório, goza[ss]em de boa fama na sociedade", ${ }^{21}$ restringindo o acesso apenas "aos indivíduos de proeminência social e econômica da cidade", ${ }^{122}$ o que revela a busca pela máxima homogeneidade possível. Esse propósito só era possível devido à coincidência entre o que se entendia como a sociedade e o perfil desejado pelo clube, uma vez que a boa fama era um dado de origem e não uma conquista social. ${ }^{123}$

Foi o primeiro a se opor ao ingresso de clubes varzeanos na Liga Paulista de Futebol e também o primeiro a se retirar quando isso aconteceu com a entrada do Sport Club Corinthians Paulista. Segundo o discurso internamente construído por meio de frequentes publicações, o Paulistano nunca se rendeu ao bicho, mantendo intocada a imagem do futebol amador que praticava:

\footnotetext{
${ }^{117}$ Vinculado ao Estado de São Paulo, ele chefiou a seção de esportes do jornal O Estado de S. Paulo até 1909. Posteriormente, passou a redigir artigos também para a imprensa do Rio de Janeiro.

${ }^{118}$ CLUB ATHLETICO PAULISTANO, op. cit., p. 27.

${ }^{119}$ O velódromo de D. Veridiana Prado, por exemplo, foi sua sede esportiva até a transferência para o Jardim América, em 1917. Anos depois, Antonio Prado Jr., neto de D. Veridiana, foi presidente e conselheiro do clube.

${ }^{120}$ Termo referente ao universo de códigos e símbolos relativos à vida esportiva da elite, em que o culto à excelência, à elegância e à relação amadora com os esportes figurava de maneira central.

${ }^{121}$ Estatuto do Clube Atlético Paulistano apud SIQUEIRA, Uassyr de. Clubes recreativos..., cit., p. 282.

122 Ibid.

${ }^{123}$ Com relação à adaptação da elite paulistana à modernização dos costumes na cidade de São Paulo, cf. SCHPUN, Mônica Raisa. Beleza em jogo..., cit., 1999; CARVALHO, Vânia Carneiro de. Gênero e artefato..., cit., 2008.
} 
O esporte caminhava para a "modernidade e o profissionalismo", e isso contrariava o espírito com que fora introduzido no Paulistano. Não havia bichos nem salários. Tanto que Friedenreich sempre jogou sem ganhar nada, senão honrarias. [...] Ao deixar o futebol, Fried conseguiu um emprego como inspetor de vendas da Antarctica, onde se aposentou. ${ }^{124}$

Essa documentação de cunho memorialístico, produzida por um associado, não nos permite saber se, de fato, Friedenreich ${ }^{125}$ não recebeu bicho enquanto jogou pelo clube, ${ }^{126}$ mas a partir dela é possível notar como se deu a construção e a valorização dessa imagem vinculada ao amadorismo.

Em 1929, quando o Paulistano abandonou o futebol - deixando claro por que o fazia; nas palavras de Antônio Prado Jr.: "não há mais o espírito puro da disputa"127 -, sua revista mensal publicou a seguinte nota: "Considerando inteiramente perdido o organismo futebolístico paulista, em virtude do vírus da anarquia, do profissionalismo e de outras mazelas que o infeccionavam - o Paulistano extinguiu sua seção de soccer". ${ }^{128}$ A analogia higienista permitia, a um só tempo, evocar um sistema em harmonioso funcionamento e denunciar a pureza por ele perdida na degeneração por vírus e outras mazelas. É interessante saber quem zelava por esse corpo e qual foi seu receituário anos antes do abandono do paciente.

Em 1925, Antônio Prado Jr., então presidente do clube, planejou, organizou e pagou, com apoio de comerciantes, industriais e da imprensa paulistana, uma excursão à Europa como a última tentativa de salvar o futebol amador. Em março daquele ano, a bordo do navio

\footnotetext{
${ }^{124}$ CLUB ATHLETICO PAULISTANO. Corpo e alma de um clube centenário..., cit., p. 58.

${ }^{125}$ Conhecido como um dos maiores jogadores da história do futebol brasileiro. Jogou pelo Paulistano durante boa parte de sua carreira e encerrou-a no São Paulo Futebol Clube, nos anos 1940.

${ }^{126}$ Embora haja indícios disso investigados por pesquisadores dedicados ao assunto. Como exemplo, cf. DUARTE, René. Friedenreich e a reinvenção de São Paulo: o futebol e a vitória na invenção da metrópole. Dissertação (Mestrado em História Social) - Faculdade de Filosofia, Letras e Ciências Humanas, Universidade de São Paulo, São Paulo, 2008.

${ }^{127}$ CLUB ATHLETICO PAULISTANO. Corpo e alma de um clube centenário..., cit., p. 58.

${ }^{128}$ Ibid., p. 59.
} 
Zeelândia, o time viajou para a França a fim de disputar um torneio pan-latino. ${ }^{129}$ Essa passagem dos jogadores do Clube Atlético Paulistano por terras estrangeiras foi amplamente acompanhada e explorada pela imprensa nacional. ${ }^{130} \mathrm{O}$ jornal O Estado de S. Paulo, por meio do jornalista Américo Netto, também sócio do Paulistano, publicava notas sobre o torneio e, em tom de coluna social, narrava momentos de descanso e lazer da equipe. Exemplo disso é a interessante descrição do encontro entre Antônio Prado Jr. e Jules Rimet, em jantar que homenageava a equipe. O conteúdo da conversa sobre o amadorismo na França e no Brasil é altamente revelador das posições assumidas diante do processo de modernização do esporte:

\begin{abstract}
Meu jovem amigo, [...] o que ha de peor em tudo isto é que [...] o sr., eu, os outros, todos nós, enfim, escrevemos sempre, falando das divisões de cada dia, 'quatorze horas', 'dezoito horas', 'vinte e três horas'. Mas nunca, note bem que nunca, ou com raridade tal que constitue verdadeira surpresa, dizemos senão 'duas horas', 'seis horas', 'onze horas'. O amadorismo é um estado ideal, um sonho de perfeição, e, assim, praticamente inattingivel. Conhecemos - sofremos mesmo - todas as manifestações do profissionalismo. Não podemos, porem, combatel-o radicalmente na sua essência, pois ela tem fundamento na própria natureza humana [...]. Podemos quando muito restringir seus effeitos. ${ }^{131}$
\end{abstract}

Para Rimet, amadorismo e profissionalismo eram essencialmente diferentes: o primeiro seria da ordem do ideal e irrealizável, enquanto o segundo se situaria, em oposição, no plano da natureza humana, do real. ${ }^{132}$ A questão amadorismo x profissionalismo não era novidade, nem mesmo exclusividade de Rimet. Inúmeras discussões a esse respeito vinham sendo realizadas na Europa em face do percurso diferenciado que o futebol parecia realizar em razão das disputas por seu controle entre a FIFA e o COI. ${ }^{133}$ No Brasil, essa questão

\footnotetext{
${ }^{129}$ Equipes argentinas e uruguaias também estiveram no torneio, mas suas participações foram avaliadas como bem inferiores à dos brasileiros. Estes venceram seis dos sete jogos que disputaram.

${ }^{130} \mathrm{O}$ acervo do clube dispõe de cópias de jornais nacionais e internacionais que acompanharam o evento. As revistas Careta e A Cigarra também noticiaram a excursão.

${ }_{131}$ O Estado de S. Paulo, 1925.

${ }^{132} \mathrm{O}$ que não deixa de remeter à perda do halo a que se referiram Baudelaire e Berman em relação à experiência moderna, aqui já explorada (Cf. BERMAN, Marshall. Tudo que é sólido desmancha no ar..., cit.).

133 A partir dos embates entre a Federação Internacional de Futebol Associado e o Comitê Olímpico Internacional diante do controle sobre o estatuto do futebol - amador ou profissional - nesses dois universos, o que se acirraria em face da primeira Copa do Mundo de futebol, em 1930 (Cf. GIGLIO, Sérgio Settani.
} 
assumia ainda outros conteúdos, pois se relacionava à popularização do futebol. Em São Paulo, o debate foi acirrado e mobilizou a imprensa, sobretudo após a criação da Associação Paulista de Esportes Atléticos (APSA). ${ }^{134}$ Uma reportagem de O Estado de S. Paulo revela uma das posições assumidas na cidade em relação à participação oficial de populares nas ligas:

parece incrível que aqui, no Brasil, paiz que se orgulha, merecidamente, dos princípios mais liberais e democráticos, em todas as suas leis e em todas as suas manifestações sociaes, possa ainda ser tolerado que, na Capital Federal e no Estado de São Paulo, fiquem consignadas as absurdas exclusões dos operários, do direito de serem considerados amadores. ${ }^{135}$

Tal posição parece ter ressoado no Paulistano. Anos antes de sua excursão à Europa, em 1918, quando esteve às voltas com a maior crise pela qual passou, o clube quis falar aos "sócios firmes nos seus postos, impassíveis ante as revezes e promptos para todas as lutas tendentes a levantar e manter o nome da nossa gloriosa sociedade", ${ }^{136}$ tendo produzido um resumo histórico em que lembrava seus feitos. Já no primeiro capítulo, o texto faz referência à popularização do futebol:

podemos nos gabar, sem receio algum, de termos concorrido, com grandes elementos, para o desenvolvimento do football em São Paulo. [...] Esse Sport, antes da fundação do nosso club [...] era cultivado por diminuto número de moços - os alumnos do Mackenzie College e os sócios do Internacional. [...] Entretanto, o esforço que ambos faziam, não apparecia fóra. Só era conhecido pelos que, por obrigação ou por devotamento, assistiam às raras justas promovidas pelos mais antigos. Cá fora, a população quedava-se indifferente. Não sabia da existência do novo divertimento. [...] Foi o Paulistano que popularizou o football. ${ }^{137}$

\footnotetext{
Representações do futebol nos jogos olímpicos e na copa do mundo. Pesquisa de doutorado em andamento. Escola de Educação Física e Esporte, Universidade de São Paulo, São Paulo, [2014]).

${ }^{134}$ Criada justamente a partir de uma cisão com a Liga Paulista de Futebol, em 1913, devido à aceitação de jogadores das classes trabalhadoras (Cf. ARAÚJO, José Renato de Campos. Imigração e futebol..., cit., p. 96). ${ }_{135}$ O Estado de S. Paulo, 25 mai. 1916, apud ARAÚJO, José Renato de Campos. Imigração e futebol..., cit., p. 91.

${ }^{136}$ Resumo Histórico do Club Athletico Paulistano. Secção de obras do Estado de São Paulo, 1918, p. 5.

${ }^{137}$ Ibid., p. 5.
} 
É interessante notar a forma como o clube aí se posiciona em relação ao Mackenzie e à população, sobretudo porque ele abandonara a Liga Paulista de Futebol, anos antes, justamente por não aceitar que esportistas e clubes varzeanos nela circulassem. Segundo Rosenfeld, à ocasião do rompimento, um representante do clube se pronunciara, estupefato, a esse respeito: "De repente apareceram inúmeros esportistas de outras zonas (isso quer dizer: dos subúrbios) e de outros costumes". ${ }^{138}$ Nota-se que quase dez anos após as notícias publicadas em $O$ Estado de S. Paulo sobre os canelas negras, o clube ainda lidava com a questão dos gestos e dos costumes populares - os quais, não se pode deixar de dizer, seriam adiante tomados como os principais responsáveis pelo alegado estilo de jogo nacional.

Como então compreender que, em 1918, o Paulistano se colocasse identificado à popularização do futebol, diferenciando-se, inclusive, da posição do Mackenzie? Vejamos outro excerto do resumo histórico:

Popularizou é bem o termo, porque, antes delle, nenhum club se resolvera a fazer propaganda. Os primeiros sócios eram, effectivamente, escandalosos. Queriam, à força, provocar a attenção de todos. [...] Ora, chamar a attenção do povo, era o melhor réclame e o mais poderoso estimulo. Sabe-se, hoje, o papel que representa o povo no Sport: é o elemento indispensável para a prosperidade dos clubs. E um club que não seja próspero, que não tenha renda, não pode aperfeiçoar-se. ${ }^{139}$

Com base nesse trecho torna-se mais evidente o posicionamento do clube diante de tal contexto: ao povo cabia a assistência, devidamente paga, das partidas; aos sócios, a fidelidade ao clube - assentada no conhecimento de sua história e na aceitação do espírito desportivo, ${ }^{140}$ e possivelmente manifesta no pagamento das mensalidades. Afora as interessantes questões de cunho interno - como a dimensão da propaganda -, o documento revela como o Paulistano se posicionou diante do novo contexto, em que os populares começavam a se

\footnotetext{
${ }^{138}$ ROSENFELD, Anatol. Negro, macumba e futebol, cit., p. 83.

139 Resumo Histórico do Club Athletico Paulistano..., cit., p. 5.

${ }^{140}$ Em outro trecho desse documento, há a descrição do que configuraria o espírito desportivo: "A vida esportiva está sujeita a surprezas. Isto é uma banalidade corrente entre os sportmen, mas que nem todos se submetem a essa verdade" (Ibid., p. 1).
} 
movimentar, com força cada vez maior, no circuito fechado do universo oficial do futebol. É nesse sentido que se pode compreender sua decisão de, primeiramente, excursionar com seu time de futebol em 1925 e, ao final do mesmo ano, ser o principal responsável pela criação da Liga Amadora de Futebol (LAF). ${ }^{141}$ Tratava-se de intensificar sua defesa do amadorismo. Cinco anos depois, porém, o clube preferiu abandonar definitivamente a prática oficial do futebol em nome daquele plano ideal - embora existam indícios de que outras razões, menos essencialistas, tenham contribuído para o fato. ${ }^{142}$ Não interessa aqui, entretanto, explorar profundamente tais razões, nem mesmo se dedicar à trajetória do Paulistano em seus primeiros trinta anos. Trata-se apenas de acompanhar, por dentro da dinâmica do clube, como ele se movimentou diante das transformações que o futebol lhe exigia, pois é isso que nos ajuda a melhor compreender a forma como o Anhanguera - nosso foco de pesquisa posicionou-se em face das mesmas questões.

O eminente processo de profissionalização do futebol - antecipado em arranjos como o mencionado bicho, a incorporação, nos clubes de elite, de jogadores das classes populares e até mesmo a integração de alguns varzeanos às ligas oficiais - produzia uma brusca mudança nos valores e critérios de ação da comunidade do Paulistano, que havia se estruturado a partir de referências mais estáveis e contínuas, como aquelas advindas do meio rural. ${ }^{143}$ Ver o

\footnotetext{
${ }^{141}$ Cuja secretaria geral foi atribuída a Mário Cardim. Adriano Neiva afirma que a criação da Liga Amadora de Futebol, a LAF, em 1925, da qual o Paulistano faria parte, também seria uma reação à crise do amadorismo (Cf. SANTANA, Leopoldo et al. Concurso comemorativo do $60^{\circ}$ aniversário da introdução do futebol em São Paulo. São Paulo: Federação Paulista de Futebol, 1954, p. 46).

${ }^{142}$ Entre essas razões estão as dívidas do clube decorrentes da crise de 1929 e, especificamente, do café em São Paulo. Tais questões são exploradas em pesquisas recentes. Cf., por exemplo, STREAPCO, João Paulo. "Cego é aquele que só vê a bola": o futebol em São Paulo e a formação das principais equipes paulistanas: S. C. Corinthians Paulista, S. E. Palmeiras e São Paulo F. C. (1894-1942). Dissertação (Mestrado em História) Faculdade de Filosofia, Letras e Ciências Humanas, Universidade de São Paulo, São Paulo, 2011; e SALUM, Alfredo Oscar. Palestra Itália e Corínthians: quinta coluna ou tudo buona gente? Tese (Doutorado em História) - Faculdade de Filosofia, Letras e Ciências Humanas, Universidade de São Paulo, São Paulo 2007.

${ }^{143}$ E aqui vale retomar a perspectiva adotada em relação ao Anhanguera de que é preciso cuidado com generalizações como a elite de São Paulo. Há que se notar as diferenças entre os grupos da elite paulistana, pois nem todos possuíam esse acentuado traço das oligarquias agrárias.
} 
futebol "sendo constituído como trabalho"144 parecia ser um dos problemas para o clube, pois representava uma inversão na forma como o esporte era tratado por seus membros. Os elementos trazidos pela popularização e pela eminente profissionalização do futebol só poderiam ser aceitos - e de maneira velada, nos casos de bicho - se viessem reiterar a excelência aristocrática do clube e não, ao contrário, para abalá-la. É nesse sentido que o Paulistano orienta sua defesa do amadorismo.

Assim, mais interessante do que investigar a veracidade - ou não - de sua natureza amadora, é compreender a que o clube reage quando evoca tal imagem em diferentes momentos de sua trajetória e analisar de que maneira sua reação contribuiu para a construção da ideia de amadorismo no período. ${ }^{145}$

Por sua vez, o Anhanguera e outros clubes varzeanos de características similares não pareciam cogitar a possibilidade de se modernizar para alçar a condição de clube da cidade por meio de sua oficialização junto às ligas de futebol e, posteriormente, de sua profissionalização, ${ }^{146}$ tal como aconteceu, por exemplo, com o Sport Club Corinthians Paulista. Para Negreiros, o clube do Bom Retiro iniciou suas atividades como um clube de bairro, ${ }^{147}$ mas

\footnotetext{
${ }^{144}$ SEABRA, Odette Carvalho de Lima. Urbanização e fragmentação..., cit., p. 358.

${ }^{145}$ Valem aqui os alertas de Marc Bloch e Reinhardt Koselleck sobre conceitos tão gerais quanto amadorismo ou profissionalismo. Para o primeiro: "Em si, essas rubricas têm [...] toda a legitimidade. Seu verdadeiro perigo vem de sua própria comodidade. Mal escolhido ou aplicado demasiado mecanicamente, o símbolo, que só estava aí para ajudar a análise, acabou por dispensar o ato de analisar" (BLOCH, Marc. Apologia da história. Rio de Janeiro: Zahar, 2002, p. 145). E para o historiador alemão, "a história social não pode deixar de considerar as premissas teóricas da história dos conceitos [...] A identificação do nível de generalização sobre o qual se está trabalhando [...] só pode ser conseguida com a reflexão sobre os conceitos ali empregados, que por sua vez ajudam a identificar, do ponto de vista teórico, a relação cronológica entre o acontecimento e a estrutura, ou a justaposição de permanência e alteração" (KOSELLECK, Reinhardt. Futuro passado. Rio de Janeiro: Contraponto, 2006, p. 117).

${ }^{146}$ As fontes do Anhanguera não permitem afirmar que não houve desejo de profissionalização do clube, mas confirmam que não houve esforço para que isso ocorresse. Embora um associado tenha sugerido a integração do clube à APEA, em abril de 1930, nada foi comentado ou encaminhado, por exemplo.

${ }^{147}$ Os raros trabalhos sobre as especificidades do futebol praticado na várzea do Rio Tietê trabalharam com a noção de clube de bairro, que se refere à ligação da entidade com sua localidade. Essa noção não era, pois, restrita ao que se passava nos clubes da várzea do Tietê, mas se estendia aos clubes suburbanos que tinham no futebol e no bairro suas principais referências (Cf. NEGREIROS, Plínio José L. de Campos. Resistência e rendição..., cit.; SEABRA, Odette Carvalho de Lima. Urbanização e fragmentação..., cit.
} 
percorreu caminhos diversos, trazendo resultados significativos que contribuíram para a transformação de algumas estruturas do futebol em São Paulo. O SCCP fez parte do processo no qual ocorre a popularização do futebol em São Paulo, entendida como a possibilidade da estrutura do futebol oficial aceitar a participação de associações esportivas de origem social diversa, avaliando, principalmente, a competência esportiva. E considerando por popularização, ainda, uma maior interferência de amplos setores da sociedade na organização e direção do futebol oficial. ${ }^{148}$

O autor revela que a integração de um clube de bairro ao futebol oficial se deu na medida em que ele se propôs a ser também um clube da cidade: um clube em acordo com a estrutura e o funcionamento da entidade que oficialmente organizava o esporte. Assim, Ypiranga, Corinthians e Palestra Itália ${ }^{149}$ tornaram-se clubes da cidade ao se filiarem às ligas oficiais, o que foi visto como um sinal de que haviam se modernizado, ou seja, progredido "esportiva, moral e economicamente" $" 150$ para tanto.

A ideia de competência esportiva, de mérito vinculado apenas ao desempenho ou à performance assumia um progressivo lugar de proeminência: por um lado, tornava-se um dos critérios responsáveis pela incorporação de oriundos das classes populares ao universo oficial do esporte; por outro, era responsável pelas tensões ocorridas em clubes tão diferentes quanto o Paulistano e o Anhanguera no início dos anos 1930. No caso do clube de elite, a ideia desestabilizava a lógica a partir da qual ele se organizava. Embora o clube não deixasse de com ela flertar, como no episódio envolvendo Friedenreich, parecia complicado deixá-la operar, sobretudo porque poderia vir a representar um novo critério para a incorporação de associados.

Em relação ao Anhanguera, a questão torna-se um pouco mais complexa. A competência esportiva tensionava os valores que animavam o espírito gregário - e hierárquico

\footnotetext{
${ }^{147}$ Cf. SCHPUN, Mônica Raisa. O cinema mudo em São Paulo..., cit.

${ }^{148}$ NEGREIROS, Plínio José L. de Campos. A cidade excludente e o clube do povo. Revista de História, São Paulo, n. 163, jul./dez. 2010, p. 214.

${ }^{149}$ Em verdade, o Palestra Itália já se organizara no sentido de integrar-se às ligas oficiais: "Logo no início de 1915 [...], é noticiada a filiação [do clube] e o pedido de inscrição para o campeonato daquele ano" (cf. ARAÚJO, José Renato de Campos. Imigração e futebol..., cit., p. 108).

${ }^{150}$ NEGREIROS, Plínio José L. de Campos. Resistência e rendição..., cit., p. 79.
} 
- do clube, espírito este criado em meio a uma experiência comunitária bastante particular. Ao mesmo tempo, era justamente a possibilidade de exercitar e exibir essa competência que animava os sócio-jogadores da entidade. Assim, ainda que o Anhanguera condenasse algumas de suas práticas - como a de participar, concomitantemente, de mais de uma entidade esportiva para usufruir ao máximo do futebol -, ele se beneficiava de tal circulação. Um ajuste de interesses entre sócios e diretoria era, pois, o fundamento da associação.

As experiências do Clube Atlético Paulistano e da Associação Atlética Anhanguera apresentam traços semelhantes em sua reação institucional a alguns dos conteúdos que a prática do futebol lhes impunha. As brigas de Saverio e de parte da diretoria no Anhanguera e a decisão de abandonar o departamento de futebol no Paulistano eram parte dessa reação e tinham por base tradições muito localizadas: o associativismo familiar, por um lado, e o ethos aristocrático, por outro. Ao contrário do que ocorreu com o Corinthians e o Palestra que trabalhavam no sentido de tomar parte dessa dinâmica, mostrando-se mais adaptados a ela, havia nos membros do Paulistano e do Anhanguera, certa “disposição de estranhamento intrínseca ao "processo de metropolização"”. ${ }^{151}$

No entanto, o estranhamento não impediu que conteúdos como a competência esportiva adentrassem seus universos. Se mesmo os conteúdos indesejáveis aos dois clubes não deixaram de por eles circular, ficaria o futebol imune às suas reações - que, em verdade, representavam o descontentamento de segmentos sociais mais amplos? Em que medida tais reações contribuíram para a criação da dicotomia entre profissionalismo e amadorismo que abriu os anos 1930? Lembremos, por ora, que, enquanto o Paulistano encerrava sua participação no futebol oficial da cidade, o Anhanguera apenas iniciava suas atividades como um clube situado no bairro suburbano da Barra Funda.

${ }^{151}$ SEVCENKO, Nicolau. Orfeu extático na metrópole..., cit., p. 30-31. 


\section{O Anhanguera, a várzea dos ítalo-brasileiros e A Gazeta Esportiva}

\subsection{Associativismo e vida de bairro}

Se o clube Paulistano desistiu de seguir oficial e competitivamente o futebol, o Anhanguera, ao contrário, prosseguia e modelava, à sua maneira, o que os novos ares e as tensões próprias do esporte lhe traziam. Não o fazia como o Corinthians e o Palestra, que rapidamente progrediram moral, esportiva e economicamente para integrar o futebol oficial da cidade, ${ }^{1}$ mas como um clube identificado e vinculado à várzea da Barra Funda, isto é, como um clube de bairro. Tomar parte em eventos sociais promovidos pelas mais variadas associações nele situadas era, nessa medida, parte substancial de seu cotidiano.

Daí não serem raros os vínculos com grêmios de natureza não esportiva, como os voltados para a dança ou aqueles exclusivamente dedicados ao teatro. Além de oferecer festas e bailes, o Anhanguera participava ativamente nos festivais cênicos que ocorriam no bairro, não apenas cedendo o espaço de sua sede social para variados grêmios, mas contribuindo com a encenação de dramas por seus grupos de atores, a despeito da descontinuidade que os caracterizava.

Desde os seus primeiros anos, o clube promoveu festivais similares aos organizados pelas companhias de teatro ${ }^{2}$ e pelos grêmios recreativos e dramáticos. ${ }^{3}$ Em 1929, por exemplo, o Anhanguera deliberou "realizar um festival dramático dançante no salão da Sede Operária, no dia 21 de dezembro. Para isso, foi nomeada uma comissão sendo dela presidente

\footnotetext{
${ }^{1}$ À época, encarnado pela Associação Paulista de Esportes Amadores (APEA) e também pela Liga Amadora de Futebol (LAF).

${ }^{2}$ Tais como: "Lega Lombarda, Muse Italiche, Città di Roma, Dopo Lavoro, Leale Oberdan ou Fratellanza del Cambucy", criadas ao final da primeira década do século XX (SCHPUN, Mônica Raisa. O cinema mudo em São Paulo..., cit., p. 76).

${ }^{3}$ Como o Grêmio Dramático e Musical Luso-Brasileiro (Cf. SIQUEIRA, Uassyr de. Entre maxixes, peladas e palavras de ordem..., cit.).
} 
o já conhecido Antonio Vignola". ${ }^{4}$ Tratava-se, pois, de uma atividade que exigia o destaque de associados para organizá-la e representá-la no bairro, o que é índice do grau de sua importância para a comunidade. Segundo Schpun, a atividade teatral foi intensa entre ítalobrasileiros por razões culturais e políticas:

a prática [nos palcos] permite o uso coletivo da língua de origem, que se vê valorizada e mesmo enobrecida por um registro diferenciado em relação à oralidade cotidiana. Além disso, os atores e atrizes dessas companhias trazem com freqüência em sua bagagem uma experiência teatral prévia, obtida na Itália. Assim, eles reatam seus laços, no país de imigração, com uma prática com a qual já estavam ligados. Do ponto de vista político, esse teatro, muitas vezes libertário, responde diretamente a preocupações militantes; a escolha do repertório passa então, quase sempre, por um filtro que obedece a fins didáticos. ${ }^{5}$

Ao mesmo tempo, sua atuação em companhias semiprofissionais e associações recreativas ou operárias representou a base para o desenvolvimento do cinema na cidade, pois "os protagonistas de um e de outro [eram] em muitos casos, os mesmos":

os ítalo-paulistanos também ocuparam uma posição determinante, figurando em grande número. Até 1919, a produção local de filmes é centralizada pelas sociedades teatrais que reúnem os imigrantes italianos - e muitos dos filmes então rodados [eram], na verdade, teatro filmado. ${ }^{6}$

Embora não tenham sido encontrados vestígios de vínculos do Anhanguera com o cinema, sua ligação com o teatro já é bastante reveladora da forma como as artes e os novos

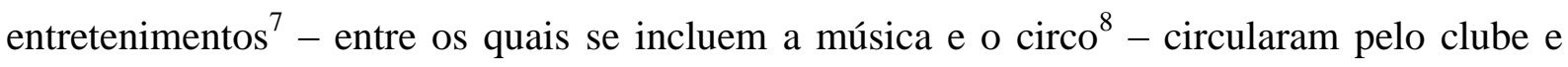
pela várzea no início da década de 1930. Eram formas de divertimento que se realizavam coletivamente, em integração com outras sociedades, como então se autodenominavam as

\footnotetext{
${ }_{5}^{4}$ Atas da Associação Atlética Anhanguera, 30 set. 1929.

${ }^{5}$ SCHPUN, Mônica Raisa. O cinema mudo em São Paulo..., cit., p. 5.

${ }^{6}$ Ibid.

${ }^{7}$ Os últimos aqui entendidos como uma série de "hábitos, físicos, sensoriais e mentais, arduamente exercidos, concentradamente nos fins de semana, mas a rigor incorporados em doses metódicas como práticas indispensáveis da rotina cotidiana" (SEVCENKO, Nicolau. Orfeu extático na metrópole..., cit., p. 33).

${ }^{8}$ Sem aqui se referir àqueles que parecem ter circulado sob outras formas nos subúrbios, tais como parques de diversão e ginástica.
} 
associações e os grêmios. Várias dessas sociedades foram estabelecidas no subúrbio, ou seja, não integravam territorialmente o que era compreendido como a cidade: o espaço entre o centro e seus limites urbanos. Como já salientado, a Barra Funda de baixo não estava incluída nesses limites.

Ao se apropriarem de maneira ativa de linguagens como o teatro, o cinema e o futebol, as associações de bairro contrariavam a perspectiva sugerida por membros do Paulistano em $1918^{9}$ de que ao povo cabia apenas a assistência a certas atividades, e não um protagonismo. Ao mesmo tempo, rompiam com a "exclusão e a delimitação espacial que a geometria lhes impunha", ${ }^{10}$ travando, a partir desses elementos simbólicos, um diálogo muito particular com a cidade.

As contribuições de ítalo-brasileiros na formação da cultura urbana que tomava forma em São Paulo no início dos anos 1930 não se restringiram, porém, às artes e aos novos entretenimentos. Como já sugerido na ocasião do convite realizado pelo Sr. Baddini, em 1928, o Anhanguera também tomava parte na movimentação política iniciada nos bairros durante os anos iniciais da década de 1930. Em 1931, na função de diretor do Anhanguera, Miguel Vignola solicitava "a cedência [da] sede social a fim de ser dado, no dia 02 de janeiro de 1932, um 'agape’ em homenagem à Legião Revolucionária da Santa Cecília, no que foi atendido". ${ }^{11}$ Já em agosto de 1932, o clube resolveu emprestar sua sede para que a Legião Paulista realizasse "o alistamento de voluntários que desejavam auxiliar a Revolução Constitucionalista". ${ }^{12}$ E, no ano seguinte, propôs-se a tomar parte em um festival que a Congregação da Barra Funda organizava na sede da Sociedade Operária. ${ }^{13}$

\footnotetext{
${ }^{9}$ Em seu resumo histórico de 1918 , analisado anteriormente.

${ }^{10}$ GAMA, Lúcia Helena. Sociabilidade e produção cultural..., cit., p. 43. Ao falar em geometria, a autora se refere principalmente ao triângulo central e ao quadrilátero urbano da cidade nos anos 1920 .

${ }^{11}$ Atas da Associação Atlética Anhanguera, 21 dez. 1931.

12 Ibid., 9 ago. 1932.

${ }^{13}$ Ibid., 19 set. 1933.
} 
Embora todos os casos sejam dignos de atenção, interessa acompanhar apenas a atuação da Congregação da Barra Funda, que vinculava seu festival à sede da sociedade operária do bairro. É preciso lembrar que o Anhanguera já havia utilizado seu salão para um festival dramático no período em que se encontrava à Rua do Córrego, onde, provavelmente, não dispunha desse tipo de espaço. A situação revela as bases de um tipo de contato entre o Anhanguera e as entidades políticas do bairro e aponta a permanência de práticas comunitárias entre associações varzeanas desde os primeiros anos do século XX. A cedência de espaços era uma delas, como revela Uassyr de Siqueira:

um fator comum entre [a associação dos] ferroviários e a Liga do Bom Retiro era o salão, cedido gratuitamente para ambas as organizações, diferentemente do caso da maioria das agremiações recreativas que solicitavam o uso do local. Algumas reuniões dos ferroviários e da liga do bairro foram realizadas no espaço do Luso-Brasileiro sem que a cessão ou não do lugar tivesse sido discutida nas reuniões de diretoria. ${ }^{14}$

Além de evidenciar permutas cotidianas, o documento revela como se davam as trocas entre entidades de natureza política (strictu sensu) e recreativa no Bom Retiro do início do século XX. Embora essas relações também carregassem certas tensões - pois atividades como o futebol não eram bem vistas nos influentes círculos anarquistas da região ${ }^{15}$ - elas não inviabilizaram esse tipo de troca. Talvez por essa mesma razão, as desconfianças em relação ao esporte e outras novidades tenham se dissipado rapidamente. Ainda para Siqueira, essa mudança de postura resultou "em modificações das práticas culturais dos militantes, que passaram a adotar elementos populares na realização de suas festividades - como o futebol e outras atividades esportivas e lúdicas". ${ }^{16}$

\footnotetext{
${ }^{14}$ Entre maxixes, peladas e palavras de ordem..., cit., p. 82.

${ }^{15}$ Como já explorado por Fátima Antunes - e Odette Seabra -, que cita, a título de exemplo, a reportagem publicada pelo periódico de inclinação anarquista A plebe, em 1933: "atualmente são três os meios que os ricos exploradores das misérias e necessidades do povo empregam para tornar a classe operária uma massa bruta: o esporte, o padre e a política" (apud ANTUNES, Fátima M. R. Ferreira. Futebol de fábrica em São Paulo, cit., p. 45).

${ }^{16}$ Ibid., p. 76.
} 
Tratava-se, pois, de uma mudança de estratégia perante a forte mobilização popular em torno de práticas não exatamente vinculadas ao universo do trabalho, mas ao seu oposto, como vimos na relação que os varzeanos estabeleciam com os bares da Rua Anhanguera. É nesse sentido que se pode compreender por que, já no início dos anos 1930, os militantes e suas associações tomavam parte nas atividades do bairro, mesmo que estas contrariassem as convicções e as práticas anteriormente por eles empreendidas. As trocas cotidianas entre associações revelaram aos anarquistas o potencial do futebol e de outras atividades no engajamento comunitário dos associados de entidades recreativas.

Explorar as específicas motivações desses grupos, no entanto, parece, aqui, menos interessante do que acompanhar sua efetiva inserção em tal universo. Uma vez que esta pesquisa procura explorar como o futebol foi recriado entre varzeanos e suburbanos, é mais proveitoso perceber que encerrar as partidas de futebol aos domingos nos bares da Rua Anhanguera era parte do cotidiano tanto de integrantes de grêmios esportivos quanto daqueles vinculados aos círculos anarquistas. Daí o papel de tais militantes na sociabilidade do bairro. Embora nem sempre conseguissem alcançar seus objetivos iniciais, muitos deles tornaram-se elementos centrais ao promoverem o contato entre associações esportivas e recreativas.

Assim, a experiência associativa estabelecida na várzea do Rio Tietê, "fortemente marcada pelas tradições culturais e políticas [...] dos grupos imigrantes" foi uma das bases materiais e simbólicas a partir das quais as entidades de bairro lidaram com o futebol, com o teatro e até mesmo com o cinema. Foi igualmente central na forma como se davam as relações entre as entidades situadas nos bairros.

\subsection{A várzea entre festivais e amistosos}

No que se refere especificamente ao futebol, há que se destacar a centralidade de uma das modalidades de encontro entre as associações de bairro: os festivais. Organizados como 
torneios competitivos que chegavam a durar fins de semana inteiros, neles se deu a maior parte dos embates futebolísticos varzeanos. Tais festivais, porém, não surgiram com o esporte; eles remetiam às festas de bairro promovidas há décadas por militantes políticos, sobretudo anarcossindicalistas. Segundo Francisco Foot Hardman, no início do século XX, além dos tradicionais festivais de propaganda, os militantes passaram a oferecer festas em cujos programas constavam atividades como a apresentação de dramas e poesias e a realização de conferências sociais e bailes. ${ }^{17}$ Entre 1920 e 1930, "começam a surgir os festivais públicos", ao ar livre, e os "festivais-espetáculo - em que se [destaca] o aspecto lúdico de entretenimento coletivo". ${ }^{18}$ A partir desse momento, eles passaram a introduzir também o futebol em seus programas, o que revela não apenas o quanto o esporte era afeito a espaços amplos e aglomerações, mas também o fato de que os militantes começavam a se valer das formas de produção de novos entretenimentos na organização dos trabalhadores.

Os festivais mantinham, ainda, profunda ligação com as festas paroquiais promovidas pela igreja católica como parte de seu calendário religioso ${ }^{19}$ e com os eventos beneficentes e de socorro mútuo. Seabra revela, por exemplo, que nas décadas de 1910 e 1920, o Correio Paulistano anunciava os festivais promovidos por associações varzeanas, como demonstra a seguinte nota: "festa esportiva no Parque Antárctica promovida pelo E.C.Lusitano em benefício da Sociedade Cruz Vermelha Brasileira e da Sociedade Protetora dos Portugueses Desvalidos". ${ }^{20}$ Havia também "festivais organizados, vez por outra, visando cooperar, em situações adversas e urgentes da vida, com alguns associados ou com famílias". ${ }^{21}$ Além de

\footnotetext{
${ }^{17}$ Segundo o programa da festa realizada, em novembro de 1902, pela Liga de Resistência entre Tecelões e Tecedeiras de São Paulo (Cf. HARDMAN, Francisco Foot. Nem pátria, nem patrão!: memória operária, cultura e literatura no Brasil. São Paulo: Editora UNESP, 2002).

${ }^{18}$ Ibid., p. $50-51$.

${ }^{19}$ Em Urbanização e fragmentação, Seabra descreve a forma como a igreja, desde fins do século XVIII, organizava a vida paroquial - em muito coincidente com a vida situada no bairro - a partir de um rico calendário de atividades coletivas (SEABRA, Odette Carvalho de Lima. Urbanização e fragmentação..., cit.).

${ }^{20}$ Ibid., p. 365.

${ }^{21}$ Ibid., p. 369.
} 
possibilitar o auxílio às entidades e aos vizinhos, tais eventos representavam o momento de comemorações coletivas e cívicas, como "aniversários dos clubes [e] também de feriados nacionais de $1^{\circ}$ de maio, 7 de setembro, $\mathrm{XV}$ de novembro. Como as datas se alternavam, tinha festa pelos campos o ano todo". ${ }^{22}$ Assim, heranças de natureza política e religiosa também foram mobilizadas no novo contexto esportivo e, nesse sentido, caberia perguntar: teriam tais heranças desdobramentos em outros níveis daquele contexto? Por ora, basta afirmar que o prestígio associado à participação em um festival não desaparecera com o futebol; muito pelo contrário, "tudo faz crer que quanto mais prestígio tivessem os clubes com eles envolvidos, maior seria a mobilização gerada". ${ }^{23}$ Ou seja, o esporte parece ter ampliado a escala dessa experiência.

Nos anos 1930, os festivais já estavam relacionados quase que estritamente ao futebol. Por essa razão, atividades tradicionais tornaram-se coadjuvantes, aparecendo apenas entre o fim de uma partida e o início de outra, como descreve Seabra: "eram muito comuns as corridas de saco para crianças, gincanas diversas [e] o baile, a conhecida soirée dançante, encerrava as atividades". ${ }^{24}$ Nem por isso tais atividades deixaram de representar um dos momentos em que crianças, mulheres e mais velhos participavam coletiva e ativamente dos divertimentos oferecidos pelos clubes.

\footnotetext{
${ }^{22}$ Ibid., p. 369.

${ }^{23}$ SEABRA, Odette Carvalho de Lima. Urbanização e fragmentação..., cit., p. 367.

${ }^{24}$ Ibid., p. 366.
} 


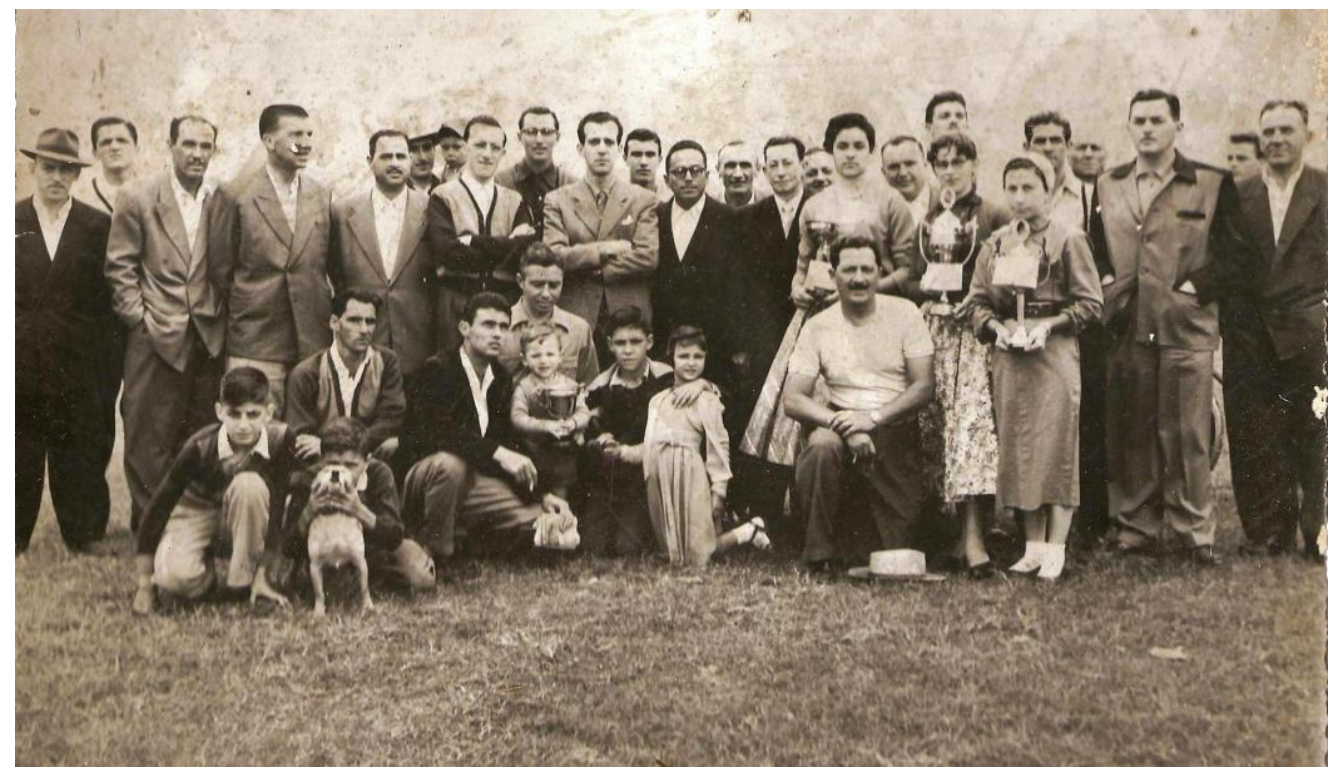

Figura 14 - Membros da Associação Atlética Anhanguera reunidos após festival, final dos anos 1930. (Fonte: Acervo do clube)

Além dos festivais, os varzeanos contavam com outra modalidade competitiva: os amistosos, que consistiam em partidas marcadas entre os times de futebol das associações sem estarem necessariamente previstas nos calendários de atividades. Seu arranjo era habitualmente realizado por paredros que, em geral, não integravam os clubes, mas conheciam muito bem seus diretores, assim como os bairros e os campos de futebol disponíveis. Tais saberes rendiam a esses articuladores pequenas gratificações por parte dos beneficiados com o jogo combinado e, em muitos casos, uma posição de liderança naquelas localidades. $^{25}$

Já outra modalidade de disputa futebolística geralmente se desenrolava apenas entre associados de um mesmo clube. Eram os famosos jogos de casados contra solteiros, que figuraram por anos como importantes momentos rituais masculinos. Tudo indica que, ao final dos anos 1930, a modalidade já estava incorporada às festividades de carnaval no Anhanguera, o que se deu a partir de uma divertida inversão: em lugar de remeter à condição masculina diante do estatuto social do matrimônio, o jogo passou a se referir à feminina ao ser

\footnotetext{
${ }^{25}$ SEABRA, Odette Carvalho de Lima. Urbanização e fragmentação..., cit., p. 337.
} 
renomeado como senhoras e senhoritas, o que, em verdade, só ampliava seu sentido ritual. ${ }^{26}$ Os veteranos do clube contam que a preparação para o embate era iniciada nos bares, onde eles bebiam enquanto se maquiavam e se vestiam de senhoras ou senhoritas. Em seguida, caminhavam pelas ruas do bairro reunindo os vizinhos para a assistência e só então se dirigiam ao campo. Ao término do jogo, o destino era, uma vez mais, os bares da região. ${ }^{27}$ No Anhanguera, essa prática durou pelo menos até meados da década de 1980.

Essas modalidades de disputa - muito próprias à vida de bairro, cujo sentido era justamente centrado na localidade - aconteciam paralela e concomitantemente aos campeonatos futebolísticos varzeanos, regidos, por sua vez, pelos tempos e modos do moderno association. A APEA, que vinha organizando parte do futebol oficial paulista, ${ }^{28}$ já incorporara uma série de clubes varzeanos na chamada Divisão Municipal, ${ }^{29}$ atendendo, assim, aos anseios de jogadores e clubes interessados no circuito em curso de valorização econômica e social do esporte. ${ }^{30}$ Ela esteve longe, porém, de reunir a totalidade dos clubes, já que uma parcela significativa deles manteve-se à parte de sua dinâmica, caso do próprio Anhanguera, que, como mencionado, não parece ter se mobilizado para isso.

Ao analisar notícias publicadas em A Plebe e A Vanguarda nos anos 1920, Siqueira revela algumas das razões pelas quais os jornais anarquistas se colocavam como mediadores das associações varzeanas contra a entidade oficial. Para A Vanguarda, por exemplo,

\footnotetext{
${ }^{26}$ Pois, com a menção ao universo feminino, completava-se o núcleo familiar, justamente o responsável pela atribuição de um novo lugar social aos nubentes. Ainda que não se aprofunde na discussão sobre esse universo, é preciso dizer que rito é aqui entendido como "um conjunto de atos repetidos que se supõe estabelecer ou recuperar certa ordenação cósmica ou humana" (FRANCO JÚNIOR, Hilário. A dança dos deuses..., cit., p. 270). ${ }^{27}$ Não se pode deixar de notar aí semelhanças com a soule, antiga festa popular que fazia parte do calendário de várias regiões da Europa, sobretudo Bretanha, Normandia e Picardia. Nela se desenrolava o jogo de mesmo nome, que "guardava o caráter totêmico de clãs em disputa: comunidades vizinhas, paróquias, cidade versus campo, casados contra solteiros, ou casadas contra solteiras" (WISNIK, José Miguel. Veneno remédio..., cit. p. 77).

${ }^{28}$ E após a unificação com a LAF, em 1929, a associação se tornaria central na ordenação do futebol profissional.

${ }^{29}$ A associação era organizada em: Divisão principal, $1^{\text {a }}$ Divisão, $2^{\text {a }}$ Divisão, Divisão Municipal e Campeonato do Interior.

${ }^{30}$ Sem esquecer, evidentemente, os campeonatos promovidos pelas fábricas sob a organização da recém-fundada Liga de Esporte, Comércio e Indústria (LECI), a partir de 1933.
} 
os critérios para o estabelecimento de duas seções no campeonato municipal de futebol [...] seriam obra de três ou quatro clubes fortes, assim chamados porque contam entre seus associados burgueses endinheirados a fim de dividir os clubes fracos dos fortes, de modo que os clubes nobres ficassem separados dos plebeus. ${ }^{31}$

Embora essas razões não fossem as únicas para tal rejeição, elas nos ajudam a compreender por que, a despeito da força das ligas da cidade no início da década de 1930 e até mesmo da entrada da imprensa esportiva nesse universo, foram mantidas nos subúrbios modalidades como os festivais e personagens como os paredros. A APEA e seus campeonatos não deixaram, no entanto, de influenciar o calendário e a própria dinâmica dessas modalidades de disputa. Os olheiros, por exemplo, responsáveis por recrutar varzeanos para os clubes da liga oficial, passaram a ser personagens tão importantes nesse universo quanto os paredros.

A esta altura já se torna evidente que o futebol vivido no Anhanguera, na Barra Funda e na várzea do Tietê não consistia em algo raro ou exclusivo. Outros bairros do subúrbio paulistano - que não eram, necessariamente, varzeanos - também integravam a mesma dinâmica. Tal é o caso de Santana, Tremembé e demais bairros localizados na região norte da cidade. A proximidade física parece ser uma das razões para tal integração, mas outros aspectos são fundamentais para compreendê-la. No que se refere à Casa Verde, ${ }^{32}$ por exemplo, que mantinha estreito contato com a Barra Funda, não parece de pouca importância o fato de que sua população vinha fundamentalmente daquele bairro, tanto da região baixa quanto da alta, o que favoreceu os mais diversos tipos de contato entre os moradores dos dois lados do rio. ${ }^{33}$

\footnotetext{
${ }^{31}$ SIQUEIRA, Uassyr de. Entre maxixes, peladas e palavras de ordem..., cit., p. 77.

${ }^{32}$ Trata-se do bairro oficialmente denominado Villa Tietê (ver planta da cidade anexa), embora fosse conhecido pelo nome do sítio onde se estabeleceu o loteamento.

${ }^{33}$ A balsa, em circulação no Rio Tietê desde 1907, e a ponte, instalada em 1920, possibilitaram que italianos mais pobres e negros atravessassem o rio para trabalhar nas chácaras que deram origem ao bairro. Tal travessia aconteceu principalmente entre os anos 1930 e 1940, o que pode ser atribuído tanto aos desdobramentos do
} 
A complexidade do futebol varzeano e suburbano não se encerra aí. Para vislumbrá-lo nesse período, deve-se não apenas acompanhar como as associações se organizaram internamente, como se relacionaram entre elas e com o bairro e como estabeleceram sua dinâmica esportiva a partir de uma delicada negociação com seus sócio-jogadores. É preciso acompanhar também sua circulação por São Paulo e até mesmo por outras cidades.

As excursões para a realização de amistosos com clubes do interior e do litoral eram parte fundamental do repertório varzeano. Em 1931, o Anhanguera já mantinha relações, por exemplo, com o Clube São João de Atibaia, ${ }^{34}$ pois adiava, por carta, seu compromisso esportivo com a referida associação. Iniciadas a partir de contatos entre familiares de associados que nelas viviam, as ligações entre clubes de cidades diferentes indicam uma específica maneira de lidar com o espaço urbano. As lembranças de um dos ex-presidentes do Anhanguera, o Sr. Salathiel da Silva, oferecem pistas para compreendê-las: "quando fui para o Anhanguera, [...] consegui fazer uma excursão até a Praia Grande. Emprestamos um trem da São Paulo Railway na época, ida e volta. Com ônibus esperando para irmos à praia de Santos". ${ }^{35}$ Salathiel era funcionário da Ferrovia Sorocabana quando foi integrado ao Anhanguera, em 1937, evidenciando a ligação de funcionários das ferrovias com a dinâmica das excursões.

Nesse período, já parecia bem estabelecida a prática do uso privativo dos trens para viagens nos fins de semana, sendo o litoral paulista seu destino recorrente. Sobre essa preferência, não se pode desconsiderar nem as facilidades relacionadas aos itinerários das ferrovias Sorocabana e São Paulo Railway, nem os apelos da paisagem marítima, tal como indicam, uma vez mais, as lembranças do Sr. Amadeu Bovi sobre suas experiências no início da década de 1920:

Plano de Avenidas, quanto às mudanças no mercado de trabalho e à expulsão dos negros do bairro (entrevista com a Profa. Dra. Odette Seabra, moradora do bairro do Limão, realizada em 20 de junho de 2011).

${ }^{34}$ Atas da Associação Atlética Anhanguera, 29 jun. 1931.

${ }^{35}$ Entrevista com o Sr. Salathiel Fernandes da Silva, realizada em 19 de julho de 2011. 
todo o ano, a oficina organizava um piquenique na praia do Gonzaga: lembro a primeira vez que vi o mar, com doze anos. Meu irmão Alfredo Bovi tinha uma Jazz Band, o Grupo Excêntrico, com oito ou dez músicos. Eles promoviam passeios, piqueniques em Santos [...]. Convidavam todos os vizinhos, íamos cem, 120 pessoas. Lá em Santos alugávamos um salão; depois do banho de mar, eles tocavam, começava a brincadeira. Íamos num trem que saía da Estação da Luz e levava de três a quatro horas para nos levar. ${ }^{36}$

Os artifícios de Salathiel e Alfredo Bovi eram semelhantes ao que Oswaldo Tirone utilizaria anos depois. Como vimos, o funcionário da antiga fábrica Brasilata dispunha do caminhão da empresa aos fins de semana e o utilizava para a locomoção do time e da torcida do Anhanguera até seus jogos na cidade, o que também não parecia incomum na região a partir de meados dos anos 1930. O crescimento e a diversificação da economia demandavam veículos de grande porte, bem como motoristas para operá-los. ${ }^{37} \mathrm{O}$ futebol, com sua rápida difusão pela cidade, demandava o mesmo. Assim, caminhões e motoristas eram colocados a serviço do esporte aos fins de semana: "De fim de semana era caminhão pra todo lado com bandeiras, flâmulas, hinos. Cada clube tinha o seu hino e isso era um exercício político e que vinha lá do fundo porque vinha da vontade de organização das pessoas". ${ }^{38}$

A independência em relação aos meios de transporte coletivo para usufruir dos tempos do esporte - que coincidiam com o tempo livre, do não trabalho - é elemento essencial para compreender a circulação varzeana. Não se pode esquecer que tais serviços estavam concentrados na região central da cidade, sendo pouco disponíveis no subúrbio, como rememora o Sr. Bertolozzi:

Condução não existia naquela época. Era o bonde. Quando o bonde vinha da Casa Verde ele nem parava aqui de tão cheio que vinha. Era bonde aberto e vinha dos dois lados cheio. O motorneiro já pegava e fazia "bim, bim, bim",

\footnotetext{
${ }^{36}$ Depoimento do Sr. Amadeu (BOSI, Ecléa. Memória e sociedade..., cit., p. 129).

${ }^{37}$ Tanto em razão do setor de alimentos - que tinha no Largo da Banana um de seus principais polos de distribuição -, quanto devido à multiplicação de fábricas na região.

${ }^{38}$ SEABRA, Odette Carvalho de Lima. Urbanização e fragmentação..., cit., p. 364.
} 
fazia tchau e ia embora. Ou então falava: "pega o de trás". 39

Por essa razão, as andanças coletivas dos futebolistas e de suas torcidas dentro e fora da cidade eram experiências que transcendiam a vida ordinária, estando mais próximas da "vida aventureira de maneira semelhante à criação nas obras de arte". ${ }^{40}$ A dimensão criativa de tais andanças se revela, primeiramente, na inversão do uso habitual desses meios de transporte. Passava-se de um uso ligado ao patrão e ao tempo do trabalho para outro relacionado ao tempo livre, da diversão, vivido coletivamente pela comunidade. ${ }^{41} \mathrm{Tal}$ criatividade se revela também em outros aspectos. Ao remeter à exibição de bandeiras, flâmulas e hinos sobre os caminhões, Seabra identifica outra importante dimensão da dinâmica varzeana: a forma como as associações esportivas e seus associados se apresentavam aos bairros e à cidade.

Um rico repertório material e simbólico, construído em diálogo com as múltiplas e difusas referências culturais que a cidade oferecia, foi colocado em funcionamento com o surgimento dos clubes varzeanos e acentuado no início dos anos $1930 \mathrm{com}$ as campanhas da imprensa, sobretudo de A Gazeta Esportiva.

\footnotetext{
${ }^{39}$ Entrevista com o Sr. José Carlos Bertolozzi, realizada em 24 de abril de 2010.

40 A noção é mobilizada por Bernardo Buarque de Hollanda para compreender as caravanas de torcidas organizadas ao final dos anos 1970. Em consonância com Georg Simmel, Hollanda define aventura como "uma vivência que se desprende do contexto e da totalidade do fluxo vital. Suspensa dele, o afastamento de determinados conteúdos de encadeamento e dos círculos homogêneos da vida proporciona a sensação de uma posição à margem do continuum da existência" (HOLLANDA, Bernardo B. Buarque de. O clube como vontade e representação: o jornalismo esportivo e a formação das torcidas organizadas de futebol do Rio de Janeiro. Rio de Janeiro: 7 Letras, 2009, p. 409).

${ }^{41}$ Talvez aqui, mais do que em qualquer outro momento do texto, seja importante afirmar a tentativa de buscar uma nova categoria para denominar o tempo do não trabalho nesse universo. A pesquisa realizada revela que toda a mobilização em torno do Anhanguera não se dava em torno da suspensão do trabalho para descanso e relaxamento, ou da mera ocupação do tempo livre, como em geral se afirma pela utilização de categorias como lazer e entretenimento para tratar do momento do não trabalho. Lazer e entretenimento nos lançam, paradoxalmente, ao mundo do trabalho, uma vez que remetem ao tempo da produção e do consumo (na medida em que são complementares a ele), e não ao tempo da criação, da diversão e da alegria, que não necessariamente se referem ao trabalho. Tal dimensão nos parece muito mais próxima ao que viviam os associados do Anhanguera. Seabra a definiu como um tempo próprio, uma criação coletiva da comunidade: "quando nós criamos uma coisa, não sou mais eu, não é mais você, é uma terceira coisa. Essa terceira coisa volta como qualificação das pessoas, [...] volta só como qualidade. Você pode decompor a identificação, as relações mais amorosas, mais conflituosas" (entrevista com a Profa. Dra. Odette Seabra, realizada em 20 de junho de 2011).
} 
No caso do Anhanguera, seu distintivo (figura 15) fora decidido já em seu primeiro ano de funcionamento, a partir do desenho de um associado, o Sr. Chiochetti, e da rápida aprovação geral da assembleia, pois ele deveria constar nos estatutos a serem registrados. ${ }^{42}$

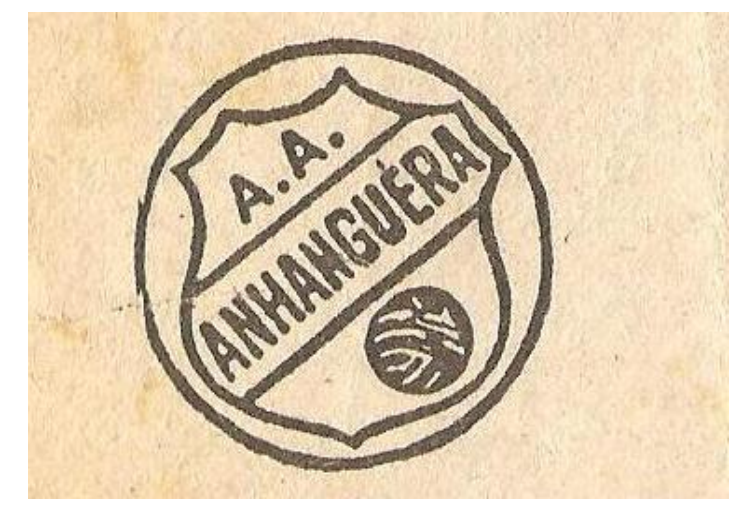

Figura 15 - Emblema da Associação Atlética Anhanguera, s.d. (Fonte: Acervo do clube)

De seu hino, entretanto, resta apenas o primeiro fragmento e não há vestígios de autoria:

Dizem que o preto é luto,

Vermelho é guerra

[...]

Associação Atlética Anhanguera

Ainda hoje é tradição ${ }^{43}$

É interessante notar que sua estrofe inicial não menciona o bandeirante Bartolomeu Bueno da Silva, cuja alcunha, de origem guarani, nomeia o clube. Ela traz apenas a referência às cores preta e vermelha escolhidas para representar o clube. ${ }^{44}$ Tomemos, então, o que está materializado nesse trecho. Embora existisse para ser reconhecido auditivamente, o hino é iniciado com uma referência à dimensão visual do clube: o rubro-negro de batismo. Como vimos, nos vários conflitos envolvendo diretores e sócio-jogadores, as cores foram tomadas,

\footnotetext{
${ }^{42}$ Atas da Associação Atlética Anhanguera, 5 nov. 1928.

${ }^{43}$ Primeira parte do hino da Associação Atlética Anhanguera, de autoria e período desconhecidos. Disponível em: <http://anhanguera.blogspot.com.br/>. Acesso em: 20 set. 2012.

${ }^{44}$ Posteriormente, nos anos 1940, A Gazeta Esportiva faria referência justamente às cores para associá-las ao bandeirante.
} 
metonimicamente, como a própria associação. Isso revela sua força simbólica ao definir, segundo Franco Júnior, "a identidade comunitária para si mesma", 45 mas também ilustra sua função operativa na dinâmica cotidiana entre clubes, por mostrar uma "imagem [construída] para as outras comunidades". ${ }^{46}$ Apesar de não terem sido encontrados vestígios das motivações para a escolha do rubro-negro como identificação do Anhanguera, as cores eram parte do repertório de códigos e símbolos das associações dos bairros. Siqueira informa, por exemplo, que,

embora não restringisse o quadro de associados aos gráficos, a Associação Gráfica de Desportos frisava a identidade em torno da categoria através de seu nome e de seus símbolos: as cores do Pavilhão Social serão azul e branco, e assim dispostas: o pavilhão propriamente dito será inteiramente azul, tendo ao centro um escudo branco com uma faixa azul em diagonal, encimada por um círculo com as iniciais A. G. D. em vermelho e em baixo e distintivo das arte gráficas. ${ }^{47}$

O excerto revela que a categoria profissional figurava como um critério para a formação de clubes esportivos e, ao mesmo tempo, como a base para sua representação simbólica, o que se dava em torno de símbolos e cores.

Outros elementos constavam (e constam) no repertório material do clube Anhanguera, tais como as bandeiras, ${ }^{48}$ as taças, os troféus, as medalhas e os uniformes. ${ }^{49}$ Os últimos, chamados à época de fardamentos, merecem destaque, pois foram objeto de constante registro pela associação, algo facilmente compreensível. Afora toda a simbologia em torno da camisa, deve-se levar em conta que, nas andanças do clube em cima dos caminhões ou em meio a dezenas de campos e partidas concomitantemente disputadas, eram as camisas que permitiam a distinção entre os clubes e a identificação com eles.

\footnotetext{
${ }^{45}$ FRANCO JÚNIOR, Hilário. A dança dos deuses..., cit., p. 217.

${ }^{46}$ Ibid., p. 218.

${ }^{47}$ SIQUEIRA, Uassyr de. Entre maxixes, peladas e palavras de ordem..., cit., p. 78.

${ }^{48}$ Das quais não são encontrados registros.

${ }^{49}$ Que, ao contrário das bandeiras, existem em número razoável e de maneira seriada na associação.
} 
Como vimos, já naquele período, as partidas nos bairros reuniam centenas ou milhares de pessoas e, diante das multidões, parecia necessário marcar visualmente o espaço ocupado pelas associações com os objetos portados por seus representantes. Assim, tal como se passava em relação às novas bandeiras - rebatizadas em pomposas festas compartilhadas com outras associações do bairro -, a renovação dos fardamentos era um momento instituído na associação. Tratava-se tanto de evidenciar a possibilidade de abastecer o clube com novas camisas, o que já era bastante valorizado entre varzeanos, quanto de revelar sua capacidade de inovação ao criar novos padrões a partir das mesmas cores. As figuras 16 e 17 ilustram essas questões:

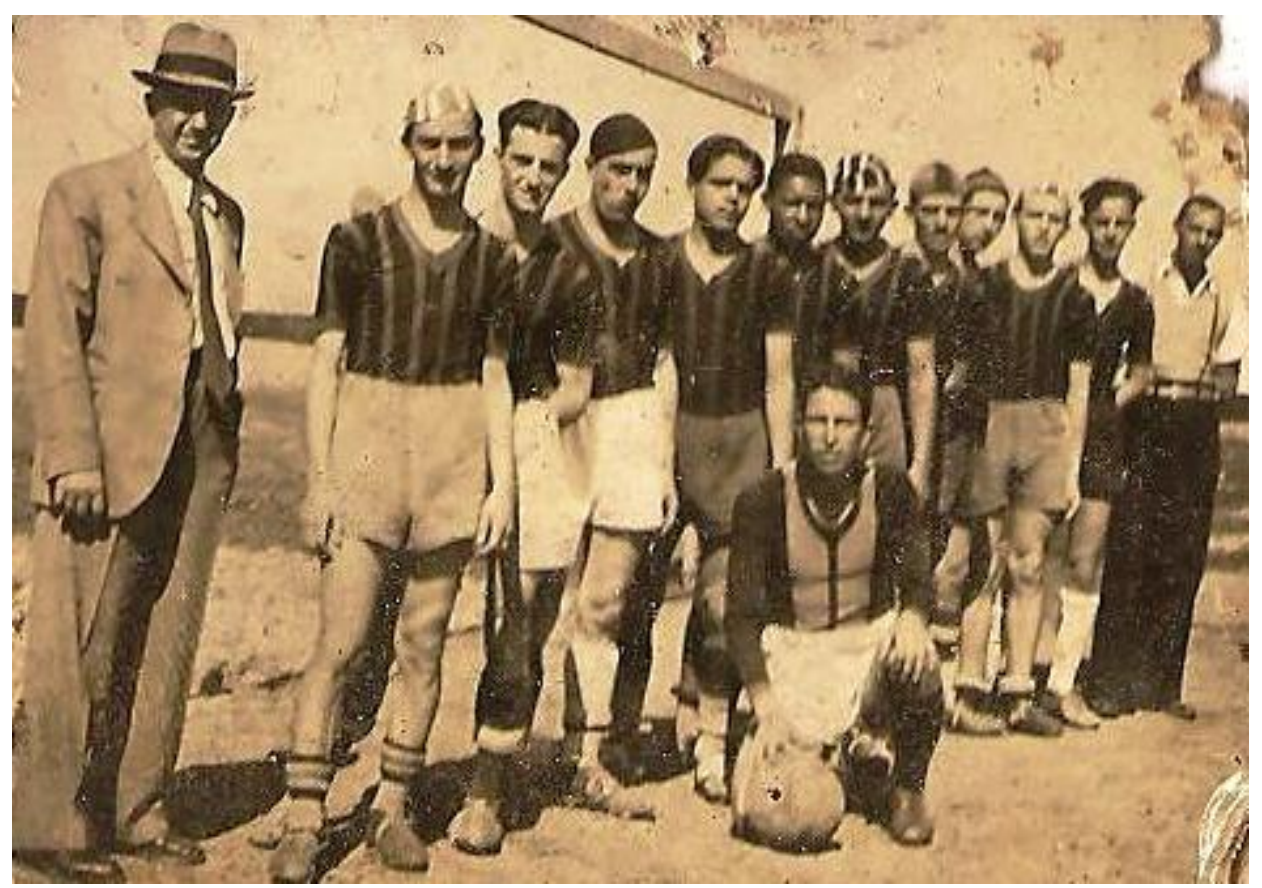

Figura 16 - Estreia de camisas da Associação Atlética Anhanguera, anos 1930. (Fonte: Acervo do clube) 


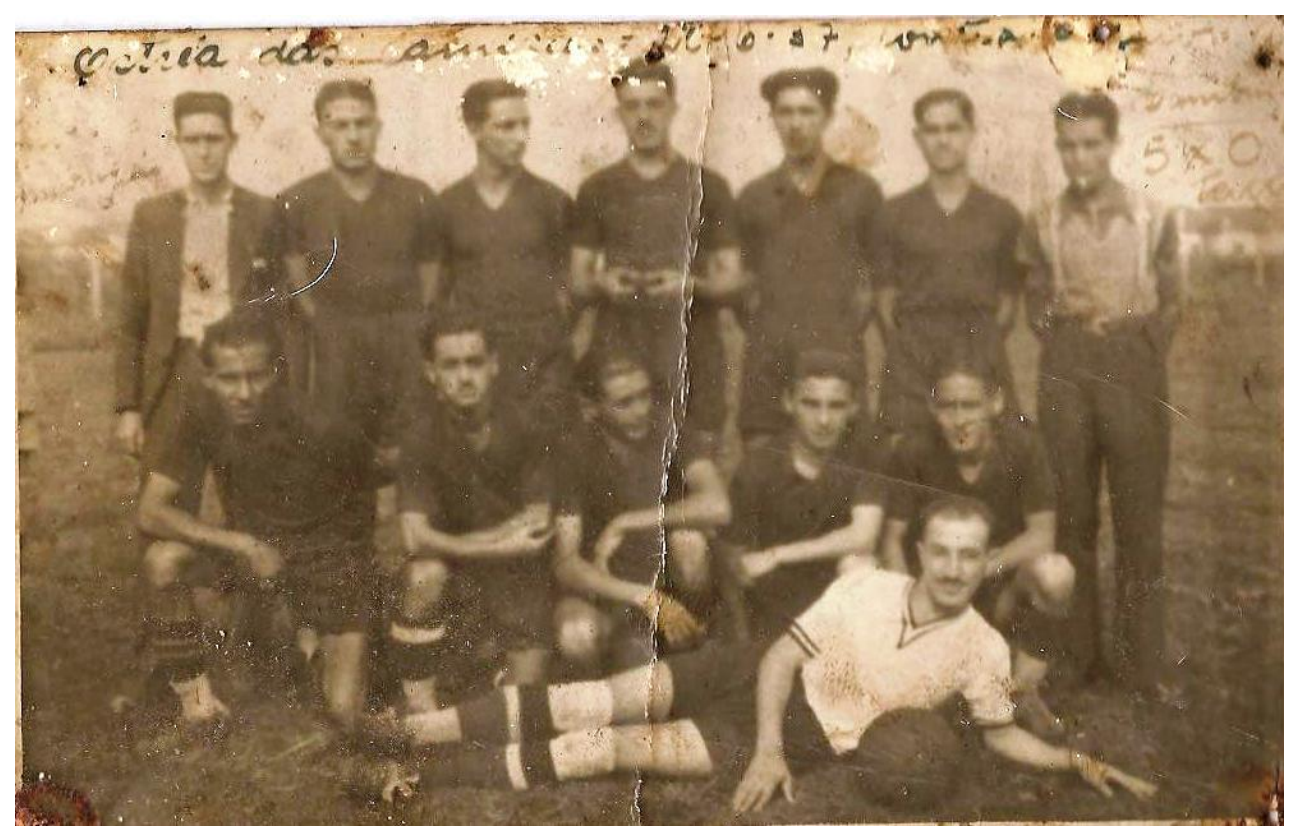

Figura 17 - Estreia de camisas da Associação Atlética Anhanguera, 1937. (Fonte: Acervo do clube)

Nessa medida, o lançamento de novos uniformes consistia em um momento mais significativo para a associação, como instituição, do que para seus associados considerados individualmente. Tal aspecto também foi traduzido, nos dois registros fotográficos (figuras 16 e 17), pela presença de representantes da diretoria do clube nas extremidades do grupo de jogadores, fechando o time. Em verdade, esse modelo fotográfico era um costume generalizado entre as associações esportivas do período, varzeanas ou não, o que só reafirma a força institucional dos clubes.

Ainda assim, os fardamentos não eram menos importantes para os próprios integrantes do Anhanguera. Nas fotografias de cunho pessoal, cujo destaque é o sujeito associado, o uniforme figura como um índice de seu vínculo com o clube (figuras 18 e 19): 


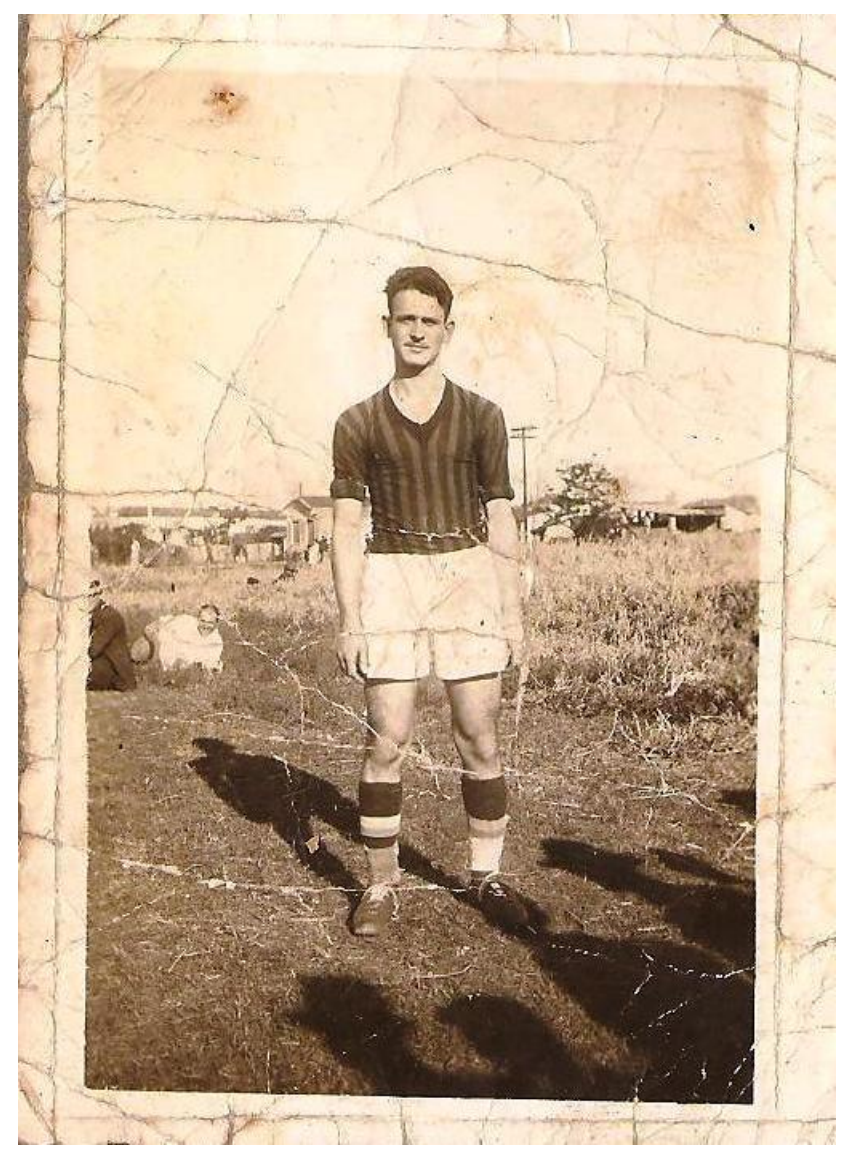

Figura 18 - Oswaldo Tirone vestido com o uniforme da Associação Atlética Anhanguera, anos 1930. (Fonte: Acervo do clube)
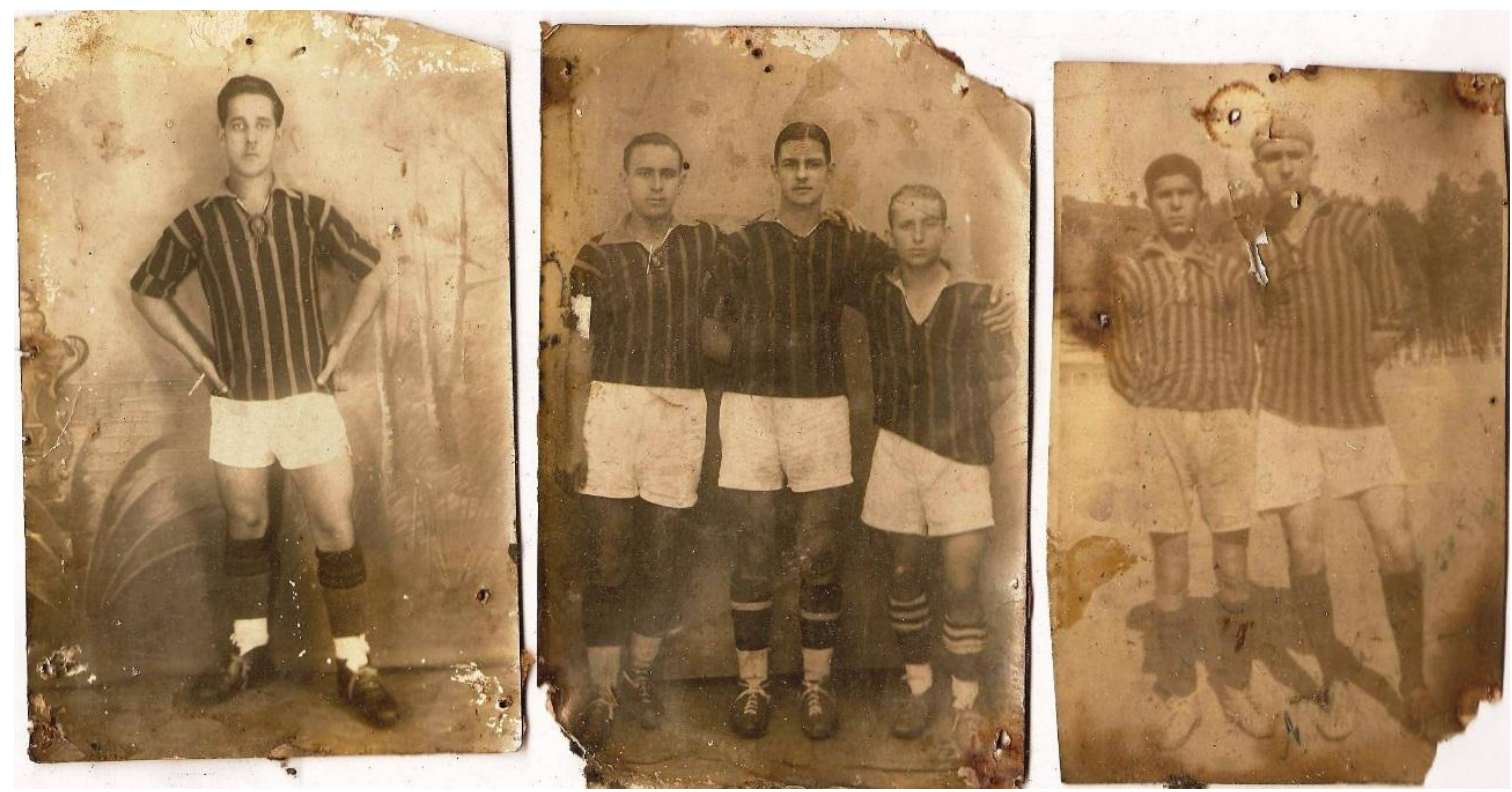

Figura 19 - Antenor Dias e sócio-jogadores dos times juvenis vestidos com uniformes da Associação Atlética Anhanguera, anos 1930. (Fonte: Acervo do clube) 
Nos relatos que fez ao neto, o mesmo Oswaldo Tirone deixou outros vestígios da importância que os fardamentos tinham em seu cotidiano:

na década de [19]20, o meu avô com alguns outros moleques fundaram um time que inclusive nasceu antes do Anhanguera, nasceu em [19]27: o Flor do Bosque. Era um time só de molecada e durou. O uniforme do Flor do Bosque [...] foi feito com saco de farinha. ${ }^{50}$

As lembranças em torno das camisas do time de meninos condensam elementos de uma identidade que deita raízes não apenas na vida de bairro, mas na superação de condições adversas a partir, uma vez mais, de soluções caseiras. Essa delicada trama entre representações identitárias coletivas e individuais, tecida pelos associados em diálogo com o repertório material e simbólico ${ }^{51}$ do clube, explica, por exemplo, a permanência de seu acervo após a passagem de quase 80 anos. Ela explica também a convergência em torno da vida associativa à época, da qual derivava a energia com que diretores e alguns associados defendiam os interesses do Anhanguera.

A trama identitária respondia, ainda, pelo cotidiano entre clubes, o que, no específico terreno das partidas futebolísticas, só pode ser compreendido a partir das disputas ocorridas nos campos, invariavelmente terminadas em discussões ou confrontos físicos. $\mathrm{O}$ acesso a essas experiências, no entanto, é complexo. Delas restam apenas algumas lembranças de veteranos que as viveram em período posterior ao aqui destacado - após meados dos anos 1940 - e narrativas reconstruídas pelos periódicos esportivos cujas especificidades exigiram tratamento diferenciado. Com estas entraremos em contato adiante.

Por ora, interessa destacar a forma como o futebol foi organizado na várzea e no subúrbio $^{52}$ por seus próprios representantes e para além dos tempos e modos da APEA. Entre

\footnotetext{
${ }^{50}$ Entrevista com Arthur Tirone, realizada em 26 de junho de 2011.

$51 \mathrm{Ou}$ totêmico, na medida em que representam "um identificador de pertencimento à comunidade e de cimentador dessa identidade coletiva" (FRANCO JÚNIOR, Hilário. A dança dos deuses..., cit., p. 220).

${ }^{52}$ Faz-se necessário indicar por que operamos tal disjunção entre várzea e subúrbio. Como vimos, a várzea do Rio Tietê sofreu uma ocupação muito específica, iniciada fundamentalmente no fím do século XIX a partir da
} 
festivais e amistosos, os clubes de bairro se multiplicaram rapidamente e promoveram a organização e a participação dos sócios em esferas coletivas. Isso perdurou até o momento em que a várzea deixou de ser um espaço que articulava os bairros em torno do futebol e passou a ser objeto de disputa entre as associações esportivas e o capital de fábricas e indústrias que nela começaram a se instalar já ao final dos anos 1920 - sem a mediação do Estado ou controle público, é preciso ressaltar. Ao mesmo tempo e a título de comparação, Schpun lembra que os representantes dos clubes de elite, por sua vez,

deixam suas fazendas e se instalam em São Paulo precisamente nesse momento de transformações [e não deixam] de praticar a política bem definida de ocupação da cidade, criando não somente locais reservados como os bairros residenciais e os lugares dedicados ao exercício da sociabilidade (clubes ou salões de baile) mas também de circuitos diferenciados de ocupação e de frequentação dos espaços públicos. [...] Trata-se de provê-la de todos os equipamentos, de lazer ou outros, que permitam aos membros do grupo dominante reconhecerem-se e orgulharemse de sua obra. ${ }^{53}$

Assim, se o Paulistano e o Anhanguera reagiam de maneira semelhante diante das ameaças representadas, por exemplo, pela competência esportiva, o modo como ocupavam a cidade colocava-os novamente em lados opostos. Os clubes de elite rapidamente se estabeleceram no centro, já concentrado e supervalorizado ao final dos anos 1920, enquanto os de bairro ocuparam as várzeas dos rios Tietê e Pinheiros, espraiando-se em suas andanças para outras regiões suburbanas e até mesmo para o interior do Estado de São Paulo. Aliás, essa relação com outras cidades revela uma interessante identidade. Em seus trabalhos sobre a formação do subúrbio de São Paulo, José de Souza Martins nota as contiguidades entre vida interiorana e vida suburbana, as quais residem fundamentalmente no fato de que, nesses

entrada massiva de imigrantes. A Barra Funda também os recebeu, sobretudo aqueles provenientes da península itálica, o que agregou contornos muito particulares à vida do bairro. É interessante acompanhar, inclusive na imprensa, o emprego específico do termo várzea em face do uso genérico de subúrbio. A nosso ver, isso tem relação com a forma como os ítalo-brasileiros e outros imigrantes organizaram-se nos bairros varzeanos: a despeito da ausência do poder público e da própria noção de espaço público, eles construíram uma rica vida associativa, cuja organização política mereceu destaque.

${ }^{53}$ SCHPUN, Mônica Raisa. Beleza em jogo..., cit., p. 18-19. 
lugares, a vida se desenrola em certo descompasso com o que se passa no centro - ainda que dele não se desvincule. ${ }^{54}$ Tal descompasso criava a sensação de que São Paulo vivia sob múltiplas temporalidades. ${ }^{55} \mathrm{Na}$ várzea, isso parecia ainda mais agudo, considerando-se a concentração de comunidades imigrantes que mantinham contatos variados com suas culturas de origem, em coexistência com negros e uns poucos caipiras, bem como com seus cortiços, chácaras e sítios, entre outros elementos. ${ }^{56}$ Essa situação estava na origem do surgimento de uma cultura transformada, ${ }^{57}$ não exatamente situada em uma ou outra espacialidade e temporalidade, mas em diálogo com todas elas.

É o que sugerem, por exemplo, as tensões vividas cotidianamente pelo Anhanguera e por outras associações de características semelhantes. Embora não caminhasse pari passu com as demandas do universo oficial, o clube não deixou de integrar a febre futebolística que tomava conta da cidade, vivendo-a sob práticas e sentidos muito próprios. Por sua vez, tais práticas e sentidos já circulavam pelo futebol oficial, tanto porque alguns clubes e seus jogadores dele tomaram parte, quanto porque a imprensa cumpriu um papel de difusão desse universo. Isso ocorreu principalmente ao final dos anos 1920, quando o discurso jornalístico sobre a várzea assumiu novos conteúdos, situação que merece ser acompanhada.

\footnotetext{
${ }^{54}$ Para o autor, "o subúrbio é o lugar em que o passado rural de algum modo sobrevive no urbano" (MARTINS, José de Souza. A aparição do demônio na fábrica..., cit., p. 48).

${ }_{55}$ Acerca do impacto geral das transformações urbanas na cidade, José Geraldo Vinci de Moraes afirma que, "além da evidente face moderna e industrial, havia resistências rurais e provincianas bem sedimentadas [...] por mais extraordinário que isso possa parecer, criando a sensação de múltiplas temporalidades [...]. Eram elementos cada vez mais rarefeitos no cenário urbano, persistentes em todo caso, como, por exemplo, na permanência e no fortalecimento de uma certa cultura transformada" (Metrópole em sinfonia..., cit., p. 143).

${ }^{56}$ Tais questões eram substrato do repertório musical que se espraiava pela cidade, por exemplo. Ainda segundo o autor: "o fato de ser povoada por imigrantes e desenraizados de todos os tipos (de origem urbana e rural) reforçou o sentimento de saudade de um tempo melhor, proporcionando a proliferação de composições de tom nostálgico e às vezes melancólico, principalmente as canções tradicionais da terra” (Ibid., p. 222).

${ }^{57}$ Ibid.
} 


\subsection{A GAZETA CHAMA SEUS JOGADORES}

Se até o início dos anos 1920 o futebol praticado nas várzeas da cidade pelos canelas negras foi tomado de maneira homogênea e, em geral, pejorativa pela imprensa esportiva então liderada por nomes como Mário Cardim e Américo Netto, d'O Estado de S. Paulo -, tal tratamento começou a ser alterado ao final daquela década por influência da circulação de novos jornais e revistas, sobretudo no Rio de Janeiro. Em São Paulo, é apenas com o surgimento d'A Gazeta Esportiva, em 1928, que esse novo tom de fato se estabelece, embora já circulasse na cidade o periódico São Paulo Esportivo, no qual trabalhava o jornalista italiano Thomaz Mazzoni. ${ }^{58}$

Criada por Cásper Líbero, ${ }^{59}$ A Gazeta Esportiva inicialmente foi publicada sob a coordenação do jornalista Leopoldo Santana ${ }^{60}$ na forma de um suplemento esportivo semanal de A Gazeta, adquirida pelo empresário uma década antes. Ainda em 1928, Mazzoni abandonaria o pequeno jornal para acompanhá-los no empreendimento. Dois anos depois, ele seria, juntamente com Santana, um dos responsáveis pela redação da folha que, por sua influência, assumiu o slogan de promotora do esporte amador na cidade.

\footnotetext{
${ }^{58}$ Vindo ainda criança da Itália com os pais para morar à Rua do Gasômetro, Mazzoni jogara futebol na várzea, "nos desconhecidos times do São Cristóvão e Eduardo Prado", até fraturar a perna, aos 18 anos de idade. Iniciouse no jornalismo logo depois (RIBEIRO, André. Os donos do espetáculo..., cit., p. 54-55).

59 "Natural de Bragança Paulista, Cásper Líbero nasceu em 1889. Seu pai, Honório Líbero, médico e político, foi um dos primeiros intendentes daquela cidade. De família abastada, ele recebeu uma educação aristocrática, primeiro em Bragança, onde passou a primeira infância, em seguida em São Paulo, para onde se transferiu com a família aos onze anos de idade. Em 1905, Cásper ingressa na Faculdade de Direito do Largo de São Francisco. Forma-se advogado em 1909, porém nunca exercerá a profissão: no mesmo ano entra no jornalismo, como repórter do vespertino A Gazeta, o mesmo jornal que alguns anos depois será seu. Em 1911, Cásper se transfere para o Rio de Janeiro e é um dos fundadores do jornal Última Hora, engajando-se na campanha de Rui Barbosa pela Presidência da República. Em 1913, de volta a São Paulo, funda a Agência Americana, primeira agência noticiosa brasileira. Em 1914, ingressa na redação d'O Estado de S.Paulo, de onde logo retorna ao Rio de Janeiro, desta vez como diretor da sucursal d'O Estado. Deixa o jornalismo por um curto período, no ano de 1917, para assumir cargo público como procurador da Fazenda Nacional no Estado do Mato Grosso. Renunciando ao cargo, retorna a São Paulo ainda em 1917, e volta a atuar como jornalista n'A Gazeta". Em 1918, ele se torna proprietário do jornal (JAYO, Martin. Trajetória e idéias de Cásper Líbero. Revista PJ:BR: Jornalismo Brasileiro, São Paulo, n. 3, $1^{\circ}$ semestre/2004).

${ }^{60}$ Em A Gazeta desde que Líbero assumira o jornal, em 1918, Santana era um ex-professor que escrevera o livro O futebol em São Paulo. Ele foi também um dos responsáveis pela primeira transmissão, por alto-falantes, de uma partida esportiva no Rio de Janeiro, a convite de Cásper Líbero (Cf. RIBEIRO, André. Os donos do espetáculo..., cit.).
} 
A Gazeta Esportiva rapidamente alcançou destaque entre os clubes de bairro e os leitores ao dedicar, já em 1929, algumas páginas exclusivas para o futebol praticado nas várzeas e nos subúrbios, contando com articulistas que desenvolviam colunas de opinião, algo realmente inovador diante da tímida cobertura do assunto em outros periódicos da cidade. ${ }^{61}$ Em verdade, até seu surgimento, periódicos como O Estado de S. Paulo e Folha da Manhã apenas começavam a alterar o tom pejorativo atribuído à prática varzeana, anunciando partidas por meio de pequenas notas como a seguinte: "E.C. Indianópolis x G.E.Carlos Gomes. Realiza-se amanhã, às $14 \mathrm{~h}$, no campo do E.C. Indianópolis, uma partida amistosa entre os quadros supras". 62

Mesmo com essa tímida cobertura, os jornais não deixaram de disputar o público varzeano com a nova folha de Cásper Líbero, que à época já alcançava a tiragem de 120 mil exemplares diários ${ }^{63}$ contra 80 mil da Folha da Manhã..$^{64}$ Esta acrescentava às suas notas uma interessante informação: "para a realização do encontro entre as turmas do C.A. Corinthians e da A.A.Anhanguera, o director deste último, por nosso intermédio, solicita o comparecimento dos seguintes jogadores, amanhã, às 13:00 na séde". ${ }^{65}$ Destacar a escolha dos clubes varzeanos para a divulgação de suas atividades tornava-se cada vez mais comum nas seções esportivas dos periódicos, e a disputa entre eles revela a importância que esse futebol vinha assumindo na cidade, bem como o crescimento do mercado editorial em torno dele.

Ao final dos anos 1920, a imprensa esportiva vinha se especializando e cumprindo um papel central na difusão e na organização do futebol, tanto em São Paulo quanto no Rio de

\footnotetext{
${ }^{61}$ Inicialmente de periodicidade semanal, o tabloide passou a ser publicado duas vezes por semana em menos de um ano, ampliando consideravelmente as reportagens e crônicas sobre o futebol de várzea.

${ }^{62}$ Folha da Manhã, 18 fev. 1928, caderno de esportes.

${ }^{63}$ Considerando-se que era um suplemento de A Gazeta. Para Gisely Hime, "um crescimento excepcional ante os 2 mil exemplares de dez anos antes, mesmo se levarmos em conta o rápido crescimento de São Paulo no período. No dia 8 de setembro de 1929, a tiragem alcança um pico de 200 mil exemplares" (Cásper Líbero entre o profissional e o mito: inventário crítico das fontes bibliográficas e hemerográficas. Revista PJ:BR: Jornalismo Brasileiro, n. $3,1^{\circ}$ semestre/2004).

${ }^{64}$ Acervo da Folha de São Paulo. Disponível em: <http://www1.folha.uol.com.br/folha/80anos/tempos_cruciais01.shtml>. Acesso em: 27 set. 2012.

${ }^{65}$ Folha da Manhã, 1 jun. 1929, caderno de esportes, grifo nosso.
} 
Janeiro, ainda que estivesse marcada por uma série de "disputas por conceitos, doutrinas e concepções do jogar e do gostar do jogo"66 entre os envolvidos com o esporte.

No mesmo período, as noções de cultura popular e futebol popular emergem com força nas duas cidades, sobretudo após a semana de arte moderna de 1922. O movimento tomaria ainda mais força a partir de 1930, no governo de Getúlio Vargas. Com o apoio de João Lyra e Fernando de Azevedo, o então presidente mobilizou o futebol como um dos elementos para compor a ideia de um caráter e de uma identidade nacional articulada ao Estado. Na cidade do Rio de Janeiro, essa questão assumiu grandes proporções. Importantes jornalistas e escritores fluminenses estiveram profundamente envolvidos com ela, o que se refletiu em seus trabalhos, sobretudo na imprensa.

O jornalista Mário Filho, que se especializava no universo esportivo, foi uma das figuras centrais na tradução do tema para a população que consumia suas notícias. Para Denaldo Alchorne de Souza, por ter "a sensibilidade de captar os sentimentos das pessoas mais simples", 67 ele transformou radicalmente a linguagem esportiva, tornando-a mais acessível às classes populares. Por meio do futebol, o jornalista tratou de temas sociais candentes de maneira simples e direta, promovendo a compreensão e até a participação do povo nos debates. Muitas de suas abordagens foram pautadas pela obra de seu amigo Gilberto Freyre, que viu na mestiçagem o traço mais marcante e positivo do caráter nacional. Não se pode esquecer que o livro de Mário Filho, O negro no futebol brasileiro, cujo prefácio foi escrito pelo próprio Freyre, é visto como uma espécie de síntese de sua experiência com as crônicas. Além disso, a obra foi um dos veículos que alçou Leônidas da Silva à condição de símbolo do futebol brasileiro, contribuindo para a construção do mito do jogador pela população. É em face da intensa atuação de Mário Filho que a imprensa esportiva assume

\footnotetext{
${ }^{66}$ TOLEDO, Luiz Henrique de. Lógicas no futebol. São Paulo: Hucitec/Fapesp, 2002, p. 175.

${ }^{67}$ SOUZA, Denaldo Alchorne de. O Brasil entra em campo! Construções e reconstruções da identidade nacional (1930-1947). São Paulo: Annablume, 2008, p. 180.
} 
nova configuração e passa a realizar a mediação entre os desejos do povo e os desígnios do Estado. $^{68}$

Embora se reconheça que A Gazeta Esportiva assumia espaço na imprensa justamente na medida em que se integrava a esse movimento cultural e político mais amplo de busca pelo popular e pelo nacional, ${ }^{69}$ há, por parte dela, uma atenção diferenciada para com os varzeanos, o que merece ser acompanhado desde os seus momentos iniciais.

Já ao final de 1928, o periódico publica em sua seção esportiva um artigo intitulado $A$ várzea terá a sua liga?. Iniciado com comentários um tanto críticos sobre as tentativas anteriores de criação de uma liga varzeana, o texto justifica por que o jornal não apoiara o último idealizador dessa ideia. Tratava-se do Democráticos Futebol Clube, cuja reputação parecia temerária ao articulista. Ao saber, no entanto, que a nova iniciativa partia dos Estados Unidos F. C., ele alterava completamente sua posição, dizendo: "para nós, que conhecemos os esforçados dirigentes daquele clube amigo, estamos certos de que, por mais árdua e espinhosa que seja a tarefa, saberão desempenhal-a com toda galhardia [...] A tentativa de se unificar a Varzea, pois, vae ser levada a frente!". ${ }^{70}$

O texto passa, então, a se referir ao diálogo entre o colunista e um representante do clube Estados Unidos, que não apenas portava um significativo nome, como era formado por ítalo-brasileiros. Segundo o artigo, o varzeano se dirigia ao articulista também como amigo e solicitava que ele "interviesse nessa campanha esportiva, facilitando pelas collunas $\mathrm{d}[\mathrm{o}]$

\footnotetext{
${ }^{68}$ SOUZA, Denaldo Alchorne de. O Brasil entra em campo!..., cit. Ainda sobre a questão, para Bernardo Buarque de Hollanda e Fátima Antunes, Mario Filho - e, posteriormente, seu irmão Nelson Rodrigues - elevou a crônica esportiva à condição de gênero literário, algo apenas sugerido pela primeira geração representada por José Lins do Rego. Profundamente envolvidos com a brasilidade, tais autores realizaram, por meio da crônica, um diálogo com a cultura popular, tendo o futebol como mediador (Cf. ANTUNES, Fátima M. R. Ferreira. Com brasileiro, não há quem possa: futebol e identidade nacional em José Lins do Rego, Mário Filho e Nelson Rodrigues. São Paulo: Unesp, 2004; HOLLANDA, Bernardo B. Buarque de. O descobrimento do futebol: modernismo, regionalismo e paixão esportiva em José Lins do Rego. Rio de Janeiro: Edições Biblioteca Nacional, 2004).

${ }^{69}$ No qual a imprensa e seus empresários - como Cásper Líbero, a família Rodrigues e, mais tarde, Assis Chateaubriand e Roberto Marinho - cumpriram papel central.

${ }^{70}$ A Gazeta Esportiva, 24 dez. 1928, p. 12.
} 
conceituado jornal 'leader' nas rodas esportivas, todas as adhesões que porventura a elle endereçarmos". ${ }^{71}$ É em razão do adjetivo amigo - utilizado tanto pelo articulista quanto pelo representante do clube varzeano - que se pode entrever o tipo de relação iniciada entre os dois universos, principalmente porque, ao que tudo indica, A Gazeta Esportiva e os varzeanos apenas começavam a construir algum vínculo. Para estabelecer o tom dessa relação, a folha não poupava nem elogios, nem críticas, ainda que as realizasse de forma velada.

Em janeiro de 1930, por exemplo, na seção Pela várzea, ela apresenta uma queixa: “A Barra Funda futebolística quietou-se. Não se fala mais nos 'formidáveis' Camerino, Anhanguera, Estados Unidos, etc. Férias, certamente". ${ }^{72}$ Embora as férias realmente pudessem ser a razão da quietude desses clubes, algo plausível para um 5 de janeiro, interessa notar o tom crítico expresso pelo periódico. ${ }^{73}$ A queixa parece ter surtido o efeito desejado, pois, em março de 1930, o tom utilizado em relação ao Anhanguera se modifica em uma de suas colunas assinadas. Ali, o articulista Rolando H. elogia a iniciativa do clube, enfatizando o fato de que ele conseguira encontrar

um nome genuinamente brasileiro [...] que representa papel saliente na historia das famosas bandeiras paulistas; que patentearam a grandeza e a riqueza do país, assim como déram mostra de bravos e abnegados uma pleiade de homens, paradigma de uma raça forte! ${ }^{74}$

Tal iniciativa parecia digna de nota num momento em que, na várzea, "pululla[vam] Cabanas, Chuta Vento, Sabiá Mimoso, Fabrica de Marmelada, Pindurassaia e muitos outros

\footnotetext{
71 Ibid.

72 Ibid., 5 jan. 1930.

${ }^{73}$ Por outro lado, as atas do Anhanguera referentes à assembleia do dia 6 de janeiro, um dia após a publicação da nota, demonstram que as atenções do clube estavam voltadas para a eleição da nova diretoria, que ocorria sempre no mês de janeiro. A questão torna-se ainda mais intrigante a partir da análise do conjunto de atas do clube, pois em quatro anos de registros semanais, há apenas duas referências a A Gazeta Esportiva, as quais não tocam, contudo, no tema das publicações do jornal. Nelas, a primeira menção ao periódico está associada ao empréstimo de camisas para o selecionado varzeano por ele organizado, em 1931.

${ }^{74}$ A Gazeta Esportiva, 27 mar. 1930, p. 8.
} 
‘animaes ferozes"”. ${ }^{75}$ A questão incomodava, sobretudo, porque a praga não estava restrita aos nomes de clubes, mas disseminava-se também nos festivais esportivos em que "foram disputados trophéos com as denominações de 'esfola cannelas', 'arranca tocos', 'galo esporudo' e outras que [...] fariam corar um frade de pedra". ${ }^{76}$

Rolando H. era o colunista mais ativo da seção Nas várzeas e nos subúrbios. No trecho a seguir é possível notar seu interesse em oferecer conselhos aos clubes que se formavam na várzea: “Temos 'suado' por todos os póros na faina de prégar aos amigos varzeanos, incitando-os a darem aos seus clubes, fundados e a fundar, nomes que possam... exprimir alguma cousa. Mas, parece que prégamos no deserto!"77

Essa pregação é iniciada tão logo o periódico passa a publicar seu suplemento esportivo. A seção dedicada aos populares ocupava duas páginas do caderno e seu título tinha o seguinte complemento: os que hoje são promessas, amanhã se tornarão campeões. Tal denominação, que sugere uma mudança de estatuto - de promessas para campeões -, oferece pistas para identificar os canais e as bases da relação que se iniciava entre o periódico, o Anhanguera, o universo varzeano e o universo do futebol oficial. Em suma: oferece elementos para explorar o contexto em que se distribuíam tais conselhos: a organização do campo esportivo na cidade. ${ }^{78}$

É preciso sublinhar que $A$ Gazeta e seu complemento esportivo não representavam uma continuação da visão de sociedade e de esporte sustentada por O Estado de S. Paulo. Sem adentrar as questões específicas relacionadas à formação da imprensa paulistana, ${ }^{79}$ há

\footnotetext{
75 Ibid.

${ }^{76}$ Ibid.

${ }^{77}$ Ibid.

${ }^{78}$ E aqui estamos evidentemente nos reportando à noção de campo esportivo desenvolvida por Pierre Bourdieu sobre a necessidade de reconhecer e delimitar o que é próprio à dinâmica do esporte evitando, assim, as análises baseadas em meras transposições ou analogias de fenômenos sociais mais amplos (Cf. BOURDIEU, Pierre. Programa para uma sociologia do esporte. In: Coisas ditas. São Paulo: Brasiliense, 1990).

${ }^{79}$ Discutidas, por exemplo, por: CAPELATO, Maria Helena. Os arautos do liberalismo: 1920-1945. São Paulo: Editora Brasiliense, 1989. E no que se refere ao futebol, cf.: ARAÚJO, José Renato de Campos. Imigração e futebol..., cit.
} 
que se considerar o caráter liberal $^{80}$ do periódico a partir de seu formato e do público ao qual se dirigia:

Cásper Líbero orientou seu jornal a uma camada nova e numerosa da população - os trabalhadores e profissionais da metrópole em ascensão. $\mathrm{O}$ jornal passa a ser pautado de acordo com os interesses dessa nova classe média, em grande parte constituída por trabalhadores imigrantes e seus descendentes. ${ }^{81}$

Assim, o lema de Mazzoni sobre a defesa do esporte amador não parecia se coadunar com aquele defendido por $O$ Estado de S. Paulo e mesmo pelo Clube Atlético Paulistano anos antes, o que se reflete também em relação ao futebol oficial. Não se pode esquecer que o periódico iniciou seus trabalhos defendendo a pacificação do futebol paulista, isto é, um acordo entre a APEA e a LAF pendendo evidentemente para a primeira, mais afeita à profissionalização do esporte. Tratava-se, pois, de uma postura integradora que vinha sob uma nova égide.

Voltemos, por ora, ao tratamento oferecido ao Anhanguera nos primeiros anos da década de 1930. Aos olhos d'A Gazeta, a várzea também estava dividida em dois grupos, e parecia difícil que o periódico apoiasse clubes cujos nomes não exprimissem alguma coisa. Nesse sentido, há que se perguntar se Fábrica de Marmelada ou Arranca tocos não denotavam enunciados e significados - bastante autorreferentes, aliás - ligados às especificidades varzeanas e aos seus praticantes. Em verdade, há que se questionar se tais nomes - e, provavelmente, as trajetórias dos clubes assim nomeados - não exprimiam justamente o que não desejava o periódico. Daí certa animosidade para com alguns deles.

É nesse contexto que os conselhos de A Gazeta pareciam surtir efeito em alguns clubes ou ir ao encontro de práticas já estabelecidas por eles. Ao final de seu artigo, Rolando

\footnotetext{
${ }^{80}$ De acordo com os estudos de Maria Helena Capelato sobre a imprensa. Em linhas gerais, nos anos 1930, um periódico liberal identificava-se com o combate aos desmandos governamentais e o fortalecimento de uma opinião pública. Sobre tal noção, no entanto, havia uma série de divergências entre os periódicos com ela identificados (Cf. CAPELATO, Maria Helena, op. cit.).

${ }^{81}$ JAYO, Martin. Trajetória e idéias de Cásper Líbero, cit.
} 
explicita as razões pelas quais se fazia necessário tomar o Anhanguera como exemplo.

Segundo ele, adotar um nome cuja referência fosse o bandeirante Bartholomeu Bueno da Silva significava "repetir a lenda creada em torno de sua personalidade". Ainda em suas palavras:

referimo-nos à grande discussão que provoca uma partida em que se empenha o Anhanguera e algum clube, principalmente si este é do bairro. $\mathrm{O}$ clube adversário (pelos seus socios), duas semanas ou mais antes do encontro, já tecem commentarios. Parece que até accordam de um grande somno [...] para enfrentar o Anhanguera revigoram-se! Clubes ha que, diante do Anhanguera 'bancam' os goyás [...] e o distincto clube barra-fundense, ou perca ou ganhe 'banca' o Bueno da Silva, o Anhanguera! ${ }^{82}$

Sem se deter sobre o tipo de argumento produzido pelo articulista ao propagandear os efeitos de se atuar sob - ou contra - a lenda do bandeirante, interessa entrever qual era a visão do periódico sobre como deveria se apresentar ao bairro e à cidade um clube de futebol de várzea. Isso se torna ainda mais agudo na semana seguinte, quando A Gazeta apresenta a trajetória de outro clube varzeano: o Garibaldi, que, como sugere o nome, também foi fundado por ítalo-brasileiros.

Garibaldi Futebol Clube. Agremiação que se enfileira modestamente entre os núcleos suburbanos. Uma vez ou outra as notícias esportivas dão algo referente às suas atividades no terreno das disputas. É só. As hostes garibaldinas por ahi ficam, quase que ignoradas do grande público varzeano. O Garibaldi F.C. ainda que pese essa frieza das chronicas e da várzea esportiva, é a única entidade suburbana que manda vir da Europa seus uniformes; Cremos que fato idêntico não se dê igual nem na APEA. Há tempos, o presidente do clube rubro, foi premiado com 200 contos na loteria. O Sr. Constantino Matarazzo (não pertence à família do Conde Matarazzo), enthusiasta de seu grêmio futebolístico, imediatamente encommendou na Itália uniformes para o $1^{\circ}$. e o $2^{\circ}$. quadro do Garibaldi F.C. É assim que, em nosso modesto conjunto suburbano, enverga nas pugnas dos arrebaldes vistosas camisas confeccionadas na Itália. Aliás, o Esperia, clube náutico, segue o mesmo uso. Manda vir da península até medalhas para seus atletas. O Garibaldi surgiu na Casa Verde em 1914 [...] no celebre torneio de Lausanne (celebre por questões de dinheiro vindas à luz após a refrega), vimos o Garibaldi à obra. Quadro aguerrido [...] onze camisas côr de sangue. Reminiscências dos batalhões do grande cabo de guerra italiano. O nosso Garibaldi, porém, em vez de espingardas, maneja com elegância convincente

${ }^{82}$ A Gazeta Esportiva, 27 mar. 1930, p. 8. 
a rudeza de suas 'chancas' sobre o dorso espherico da pelota de couro... 'tiros' que redundam na extrema cordialidade existente nos meios varzeanos. ${ }^{83}$

O periódico afirma, ainda no mesmo artigo, que o Anhanguera teria se originado de uma cisão com o Garibaldi:

O Garibaldi F.C. surgiu na Casa Verde em 1914, seis annos depois, em 1920, retirou-se da actividade esportiva, reapparecendo em 1927. Descansou sete anos [...]. A AAA veio à cena futebolística de uma cisão do clube garibaldino. Nesse tempo, já o bando da camisa encarnada tinha sua sede na Barra Funda. ${ }^{84}$

O documento é riquíssimo e, ainda que aqui não se possa explorá-lo em todas as suas possibilidades - uma vez que nos interessa apenas acompanhar como o periódico construía sua relação com os varzeanos e especificamente com o Anhanguera -, parece importante fazer referência à forma como foram tecidas as informações sobre o Garibaldi. O articulista destaca, por exemplo, dados sobre as relações do clube com a Itália, as quais não passam nem por famílias poderosas, como a do Conde Matarazzo, nem por clubes de renome, como os ligados à APEA. Ele sugere que tais relações apenas reafirmam o que a folha já notara: embora modesto, o clube manejava uma história de valor que - parece necessário reafirmar - se condensava nas camisas. Estas eram as responsáveis por apresentar a ligação de seus associados tanto com a Casa Verde, quanto com a Itália, ligação que o Anhanguera, por exemplo, não parecia reivindicar, embora seus integrantes mantivessem relações com associados do Palestra Itália, entre outros. ${ }^{85}$

Por fim, há que se notar que o jornal contraria a versão dos veteranos do clube sobre a cisão que fundara o Anhanguera. Sem se deixar aqui seduzir pela busca da verdadeira origem,

\footnotetext{
${ }^{83}$ A Gazeta Esportiva, 30 mar. 1930, p. 12.

84 Ibid.

${ }^{85} \mathrm{E}$, nesse sentido, há que se perguntar se a diferença entre a idade do Anhanguera e a do Garibaldi, bem como sua inserção na Casa Verde e não na Barra Funda, não representa a chave para compreender um laço mais estreito deste último com a Itália. Os vínculos do Anhanguera com o Palestra Itália passavam por diversos níveis, e um deles eram os contatos familiares.
} 
é interessante observar o exercício do articulista entre fevereiro e março de 1930. Em três semanas, ele apresenta uma forte rede de relações entre os clubes Anhanguera e Garibaldi e entre os bairros Casa Verde e Barra Funda com a Itália. A questão reaparece em outros artigos. Em 1931, a folha narra um confronto cujo protagonista foi o clube Carlos Gomes: "Domingo último, uma grande multidão dirigiu-se ao campo do verde e amarelo. Não eram unicamente seus adeptos. Havia grande parte dos esportistas da Barra Funda, do Bom Retiro e da Casa Verde". ${ }^{86}$ Parece evidente a ligação entre os bairros varzeanos com base em vínculos longínquos. E, ao mesmo tempo, que as cores do ítalo-brasileiro Carlos Gomes eram o verde e o amarelo, revelando os efeitos de desenraizamento e enraizamento a partir da segunda geração de imigrantes.

Com base nessas questões, há elementos suficientes para afirmar certa preferência d'A Gazeta Esportiva pela várzea dos ítalo-brasileiros: enquanto existiram, as colunas eram preferencialmente dedicadas aos seus clubes. ${ }^{87}$ Temos aí elementos para tecer hipóteses sobre o modelo integrador - e um tanto homogeneizador - que o periódico adotara ao tomar os clubes de ítalo-brasileiros como os principais representantes da várzea. A específica relação entre A Gazeta e o Anhanguera esclarece alguns aspectos dessa questão.

\subsection{A Gazeta Esportiva e a Associação Atlética Anhanguera}

Durante toda a década de 1930, A Gazeta Esportiva publicou a seguinte nota: "Essa página de nossas edições dos domingos será sempre reservada aos clubes das várzeas e dos subúrbios. Publicaremos toda e qualquer notícia que nos fôr enviada o mais tardar até às 15 horas dos sabbados". ${ }^{88}$ A demanda do periódico vinculada à organização da folha dos domingos parecia encontrar correspondência nas aspirações de visibilidade dos clubes

\footnotetext{
${ }^{86}$ A Gazeta Esportiva, 1 out. 1931.

${ }^{87}$ Durante o período em que as colunas existiram, até a primeira metade de 1932, elas raramente trataram de outros clubes, fossem eles de nacionais ou de imigrantes.

${ }^{88}$ A Gazeta Esportiva, 5 abr. 1931.
} 
varzeanos perante a cidade. Notas como a que segue eram reproduzidas, às dezenas, a cada semana pelo jornal: "C.A. Bom Retiro (3) X A.C. Corinthians (B. Retiro) (1). Effectuou-se ontem, num festival realizado no campo do Juta Sant'Anna, o encontro entre os dois times supra. A partida foi interessante e animada". ${ }^{89}$

Essa sintonia de interesses era viabilizada pela cooperação entre varzeanos e jornalistas na produção das pautas, tal como indicava a solicitação do periódico. Muitas vezes, as notas chegavam prontas à redação, sendo redigidas até mesmo em papéis de pão. ${ }^{90}$ Em outras ocasiões, eram criadas em parceria com jornalistas na redação. Talvez fosse essa a razão de tantas notícias publicadas em tom absolutamente informal e familiar:

Juv. Anhanguera X Juv. Garibaldi. Realizou-se ontem, pela manhã, no estadiozinho do México, a lucta acima. A preliminar foi favorável ao 'Tigrinho' pela contagem de 2 a 1 . A lucta principal terminou pela mesma contagem, sendo que os pontos do quadro de Flautin foram de Fuzarca e Cazzalli [...] Domingo, 24, 'Tigrinhos X General Ozorio, na cancha do segundo, na Várzea do Penteado. ${ }^{91}$

Não havia apenas coincidência entre as demandas do periódico e os desejos dos clubes populares, mas um ajuste, uma adaptação entre as rotinas desses universos, que começavam a se influenciar mutuamente. ${ }^{92}$ As publicações eram realizadas às terças-feiras e aos domingos, indicando que a seção varzeana se orientava fundamentalmente pelos ritmos do futebol. Os resultados das partidas eram veiculados às terças-feiras; já os domingos eram dedicados a noticiar apenas o que aconteceria no mesmo dia: quais jogos seriam realizados, quais eram suas escalações, a localização dos campos etc.

O fluxo de notícias se dava, pois, num compasso diferente do cotidiano dos clubes varzeanos, não abrangendo, por exemplo, os momentos que antecediam ou sucediam as

\footnotetext{
${ }^{89}$ Ibid., 21 mar. 1932.

${ }^{90}$ Ibid., p. 364.

${ }^{91}$ Ibid., 1 mai. 1932.

92 Embora não se possa desenvolver aqui, há que se considerar, ainda, as formas pelas quais o rádio dialogou com o meio futebolístico.
} 
disputas futebolísticas. Como vimos, tais momentos - acompanhados por jogos, bebidas, narrativas e conflitos terminados em botequins da Rua Anhanguera - eram tão importantes quanto os próprios embates do futebol. O tratamento empreendido pelo jornal consistia, portanto, em isolar a partida das demais atividades a ela associadas.

Por outro lado, é curioso notar que o periódico possibilitava a circulação de informações novas, como quando apresentava as escalações dos times incluindo as posições táticas dos jogadores, o que se infere a partir da pontuação utilizada como no texto a seguir:

O Anhanguera venceu os Estados Unidos por 3 a 1. [...] os quadros do Anhanguera eram os seguintes: $1^{\circ}$ - Raphael; Denuzzo, Grecchinno; João, Mengato e Barthô; Finho, Cimino, Saverio, Grecco e Ennio.

$2^{\circ}$ - Paulino; Moreira e Dib; Salvador Chinaglia e Gino; Chico, Rosario, Nini, Chiquinho e Antonio. ${ }^{93}$

Não se sabe se tal recurso era acessível aos leitores de A Gazeta, mas a pontuação se repete em várias outras notas. Vale mencionar que ela revela que o esquema tático - o 2-3-5 era também o mais utilizado na várzea. Esse ajuste entre as rotinas e demandas do jornal e dos clubes só pode ser compreendido a partir da cooperação estabelecida entre eles. No caso do Anhanguera, o tema é constantemente rememorado por seus veteranos, conforme relata o Sr. Salathiel da Silva: "nós mandávamos todo o nosso noticiário, todos os jogos que tínhamos. Nós mandávamos os resultados e eles publicavam na terça-feira. [...] sempre fomos bem tratados e bem cuidados pela Gazeta". ${ }^{94}$ Já o Sr. William Sandonato lembra-se de que havia "uma pessoa aqui que era d’A Gazeta Esportiva, então nós íamos sempre falar com ele. Depois eles faziam as reportagens do Anhanguera". 95

\footnotetext{
${ }^{93}$ A Gazeta Esportiva, 31 mar. 1930.

${ }^{94}$ Entrevista com o Sr. Salathiel Fernandes da Silva, realizada em 19 de julho de 2011.

${ }^{95}$ Entrevista com o Sr. William João Sandonato, realizada em 23 de maio de 2010.
} 
Os veteranos revelam que a relação do Anhanguera com A Gazeta foi mediada pelo sócio Ângelo Catapano ${ }^{96}$ durante três décadas, precisamente entre os anos 1930 e 1960 . Além de secretariar as reuniões do Anhanguera e de se tornar um de seus diretores sociais já em 1931, Catapano foi um importante redator do jornal da Barra Funda, que mantinha estreito contato com A Gazeta Esportiva. Era ele o responsável por levar à redação do periódico esportivo o que deveria ser publicado sobre o clube. Nesse interim, o Sr. Catapano acumulou um profundo conhecimento sobre o bairro e o futebol de várzea e, por essa razão, foi entrevistado por vários interessados na história da Barra Funda. Além disso, recebeu uma homenagem, ainda nos anos 1950 ao emprestar seu nome a uma das vias paralelas à Rua Anhanguera.

Embora importante, Catapano não parece ter figurado como o único mediador das relações entre a imprensa e os clubes de futebol na várzea. O Sr. Amadeu Bovi também se refere a esse papel de comunicação com a imprensa da cidade: "meu tempo de juventude foi muito empregado no esporte; organizava jogos, escalava os times, dava notícias para a Gazeta. Dirigi o Clube São Cristóvão aí do Brás, composto de vendedores de jornal". ${ }^{97}$ Antes de prosseguir, parece importante notar que, coincidentemente, o Sr. Amadeu Bovi e Thomaz Mazzoni fizeram parte do mesmo clube em período bastante próximo e a atuação de Mazzoni no clube de vendedores de jornal suscita hipóteses sobre as relações e os circuitos que o levaram ao jornalismo.

Quanto à frequência de uma mesma pessoa em diferentes tipos de sociedade, tal como se passava com Bovi, Catapano e Mazzoni, vimos que não se tratava de um expediente incomum na passagem dos anos 1920 para a década seguinte. Ao contrário, havia muitas

\footnotetext{
96 Catapani, na versão anterior. Após 1937, a legislação do Estado Novo impôs, entre outras normas já exploradas aqui, que os nomes italianos terminados em $i$ fossem abrasileirados, passando a terminar em $e$ ou $o$. Catapano se associou ao clube em novembro de 1928.

${ }^{97}$ BOSI, Ecléa. Memória e sociedade..., cit., p. 137.
} 
semelhanças com o que se passava em relação às atividades por eles desenvolvidas, não sendo raro que as pessoas desenvolvessem várias delas de maneira concomitante.

O memorialista Jacob Penteado relatou, por exemplo, “a participação de Marino Spagnolo, vidreiro e alfaiate, morador do Belenzinho, 'homem de idéias revolucionárias' como presidente de 'sociedades de classe, clubes recreativos e sociedades esportivas"'.98 Catapano e Mazzoni apresentam trajetórias semelhantes à do citado Spagnolo - e talvez até mesmo à trajetória de seu cronista. $\mathrm{O}$ que aqui nos interessa é justamente a dinâmica que possibilitava o estabelecimento desses perfis, ${ }^{99}$ pois ela é uma das chaves para a compreensão das relações entre varzeanos e imprensa.

No início da década de 1930, São Paulo se encontrava num processo de plena expansão e diversificação de sua economia, o que demandava o amplo e diversificado engajamento de seus habitantes em variadas atividades. A imprensa esportiva não fugiu à tendência, como se vê na descrição realizada por André Ribeiro:

quem escrevia nas redações era chamado de 'noticiarista', que recebia informações externas e as transformava em notícias. No assunto futebol, dirigentes e sócios dos clubes eram as principais fontes que alimentavam os noticiários. A informação, quando divulgada, tinha de ser feita de maneira objetiva, sem detalhes; bastava dizer qual o jogo, local e resultado. [...] nas raríssimas reportagens assinadas, o que se via era normalmente um pseudônimo assumir a autoria do texto. As redações eram muito pequenas. [...] esse mesmo pseudônimo escrevia sobre futebol e também era responsável por outras colunas do jornal. ${ }^{100}$

\footnotetext{
${ }^{98}$ SIQUEIRA, Uassyr de. Entre maxixes, peladas e palavras de ordem..., cit., p. 82.

${ }^{99}$ E que trouxe uma série de consequências para, por exemplo, o universo da música, o que fica evidente na trajetória de alguns importantes artistas populares como João Rubinato (Adoniran Barbosa) (Cf. MORAES, José Geraldo Vinci de. Metrópole em sinfonia..., cit.).

${ }^{100}$ Os donos do espetáculo..., cit., p. 25. Capelato faz relato similar quando explora a trajetória da Folha da manhã: "Oficinas, redação e gerência, era tudo uma coisa só. O balcão da gerência ficava quase na porta da rua. Atrás dele estava sendo montada a primeira máquina de impressão do jornal. Depois da máquina de impressão vinham, em fila, olhando para a parede da direita, as seis primeiras máquinas de composição. Ao lado delas, olhando para a parede da esquerda a mesa do Olival [Costa, proprietário do jornal] bem rente à do paginador. Mais ao fundo, junto à clandra, a mesa dos redatores. No porão, as caldeiras. As bobinas de papel entulhavam, no armazém, o corredor improvisado pela distribuição das máquinas e das mesas" (MOTA, Carlos Guilherme; CAPELATO, Maria Helena. História da Folha de S.Paulo (1921-1981). São Paulo: Impres, 1981.
} 
A caracterização de tal cotidiano em São Paulo e no Rio de Janeiro nos primeiros anos do século XX aponta para a participação de dirigentes e sócios dos clubes do futebol oficial na redação das notícias dos jogos. Diga-se de passagem, esse era um recurso do qual $A$ Gazeta ainda lançava mão passados 20 anos do referido período, sendo ativo mesmo mais adiante em jornais como $O$ Dia, que, em março de 1957, solicitou aos varzeanos que enviassem seus comunicados "escritos e bem escritos, dando inclusive os quadros [...] se escrito à mão, muito bem legível [...] mas não se esqueçam de marcar a visita. Vocês sabem quantos são os nossos clubes? Que seria do repórter se todos viessem sem aviso prévio?". ${ }^{101}$

Outro interessante recurso mencionado por Ribeiro é o uso de pseudônimos, o que nos interessa compreender em detalhes. Rolando H. assinou grande parte das colunas no período de maior dedicação à várzea, entre 1929 e 1932, no entanto, não há nenhuma referência à sua biografia no acervo do jornal. ${ }^{102}$ Seria Rolando H., por acaso, mais um dos pseudônimos de Thomaz Mazzoni? E seria seu profundo conhecimento do que acontecia na várzea fruto do tempo em que por ela circulou como jogador? Viria daquela experiência certa preferência pela várzea ítalo-brasileira? Não se pode, ainda, responder a essas questões com certeza.

De todo modo, por ora, tais questionamentos importam na medida em que iluminam a forma como o Anhanguera se colocou e foi integrado ao futebol da cidade pela folha. É importante também observar como os clubes varzeanos contribuíram para a circulação de uma série de práticas, valores e sentidos ligados ao futebol, os quais, aos poucos, extrapolaram seu campo de atuação.

Assim, em face da guinada jornalística em relação ao popular em meio à configuração da imprensa esportiva é que se pode entender como associados e jornalistas negociaram a imagem dos clubes varzeanos. No que se refere especificamente ao periódico de Cásper

\footnotetext{
${ }^{101}$ SEABRA, Odette Carvalho de Lima. Urbanização e fragmentação..., cit., p. 371.

${ }^{102}$ Segundo informações do responsável pelo acervo da Fundação Cásper Líbero.
} 
Líbero, tudo isso precisa ser considerado à luz de sua atuação, bem como à de Leopoldo Santana e Thomaz Mazzoni.

Interessado em vincular sua folha às imagens do moderno e do nacional, Cásper Líbero trabalhava com os seguintes lemas em seu jornal: "para um Brasil cada vez maior e melhor" e, "por São Paulo, a locomotiva do país na construção de uma nação maior e melhor". ${ }^{103}$ A referência a São Paulo não era gratuita. Cásper, ligado ao Partido Republicano Paulista, ${ }^{104}$ era contrário à figura de Getúlio Vargas e imprimia certo enfrentamento a ele em seu periódico. A afirmação do nacional em A Gazeta tinha, pois, um claro tom regionalista.

Quanto a Mazzoni, embora não se possa garantir que fosse o colunista encarregado dos textos de Nas várzeas e nos subúrbios, sabe-se que ele respondia pelo conteúdo veiculado, além de assinar as pequenas notas de curiosidades esportivas sob o pseudônimo de Olympico. ${ }^{105}$ A pergunta é inevitável: não seriam os imigrantes, sobretudo os italianos, os modelos - de trabalhador e de classe média - desejados por A Gazeta para veicular as imagens de uma nação moderna? É preciso lembrar, uma vez mais, que tal perspectiva - que tomava a comunidade imigrante como constitutiva do povo brasileiro - contrariava, por exemplo, o que até então afirmavam periódicos como O Estado de S. Paulo. ${ }^{106}$

Foi essa ampla movimentação política e cultural, da qual fez parte o periódico esportivo, que acabou por colocar em destaque o futebol de várzea. Os varzeanos, por sua vez, não ficariam apenas a reboque das demandas e dos desejos da imprensa. Esta foi muito utilizada por eles, tornando-se tanto um veículo para a troca de informações, quanto um

\footnotetext{
${ }^{103}$ HIME, Gisely Valentim Vaz Coelho. Cásper Líbero entre o profissional e o mito..., cit.

${ }^{104}$ Que representava a maior oposição a Getúlio Vargas.

105 Apelido que ganhara "por conhecer profundamente todos os esportes" (RIBEIRO, André. Os donos do espetáculo..., cit., p. 68).

${ }^{106}$ O pesquisador José Renato Araújo explora de maneira profunda como o jornal se posicionou, por exemplo, em relação ao que representava a ascensão de um clube da comunidade ítalo-brasileira como o Palestra Itália anos antes (Cf. ARAÚJO, José Renato de Campos. Imigração e futebol..., cit).
} 
espaço de visibilidade e representatividade social desses grupos, processo que responderia pela circulação de novas ideias em relação ao futebol da cidade.

\subsection{A várzea tradicional d'A Gazeta}

\section{A VARZEA TRADICIONAL}

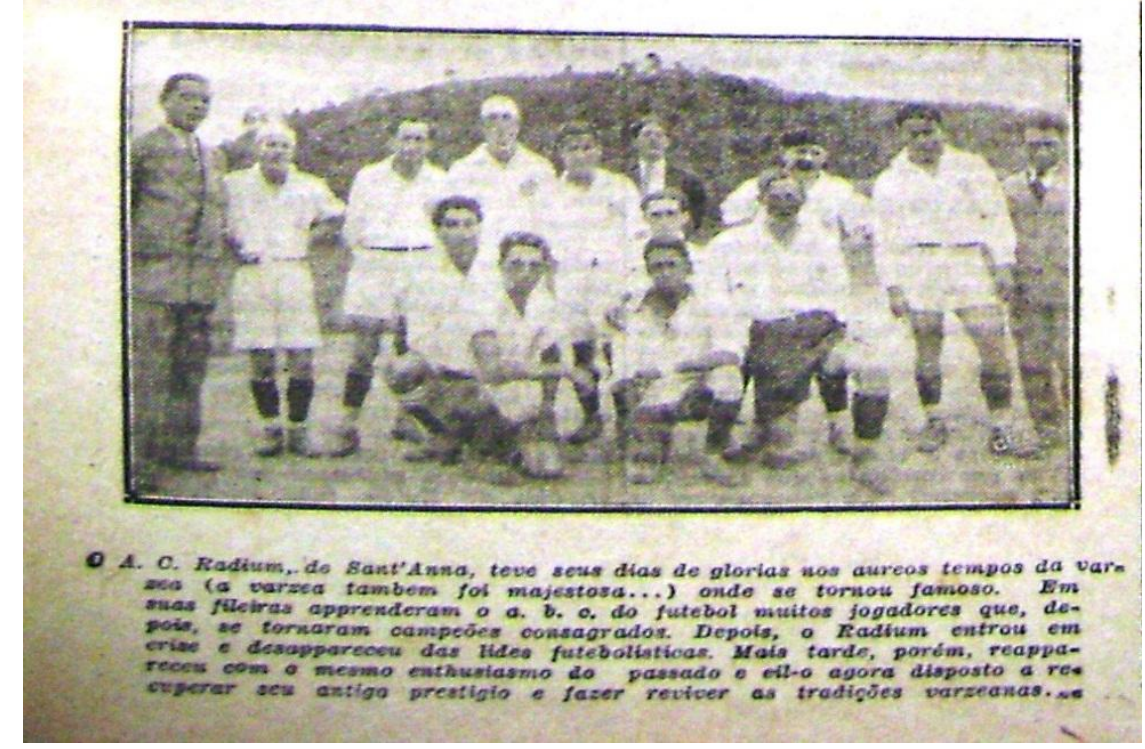

Figura 20 - Reprodução de fotografia e legenda de A Gazeta Esportiva, 6 jan. 1930. (Texto sob a foto: “A. C. Radium, de Sant'Anna, teve seus dias de glorias nos aureos tempos da varzea (a varzea também foi majestosa...) onde se tornou famoso. Em suas fileiras apprenderam o a. b. c. do futebol muitos jogadores que, depois, se tronaram campeões consagrados. Depois, o Radium entrou em crise e desappareceu das lides futebolísticas. Mais tarde, porém, reappareceu com o mesmo enthusiasmo do passado e eil-o agora disposto a recuperar seu antigo prestigio e fazer reviver as tradições varzeanas.”)

O trabalho cooperativo com a imprensa parecia cada vez mais compensador naquele ano de 1930. Além das pequenas notas, como a reproduzida na figura 20 , em que se destacavam não apenas as associações, mas o que elas representavam para o periódico, outras reportagens e colunas foram publicadas dando destaque às especificidades varzeanas. Em maio, um importante embate do futebol oficial acabou se tornando mote para explorar tais particularidades:

A várzea torce hoje, com o coração, pelo embate Palestra-Corinthians. A consagração dos que vivem nas várzeas e subúrbios. A várzea em peso 
discute hoje o prélio a realizar-se na Fazenda entre o Palestra e o Corinthians. Ninguém melhor do que o varzeano, sabe torcer pelos embates da APEA [...] chovem apostas. Macarronadas contra vinhos, cervejas às dúzias, quartos de cabritos e passeatas em autos macios. [...] os jogadores passam por severas analyses dos 'entendidos'. Esses technicos que pullullam na várzea, congregam ao redor de si, nos botecos e salões de barbeiros ou portas de cinemas, a classica rodinha dos que gostam de ouvir a opinião alheia. [...] os elementos populares, não obstante a repulsa dos da 'alta', dos 'aristocratas', serão sempre os verdadeiros esportistas. É só nos subúrbios, entre a massa do Zé povinho, que se encontra a torcida consagradora dos grandes feitos [...]. Mas o varzeano será o eterno 'resto', a quem os da elite só em última estância recorrerão, esquecendo-se da extraordinária força que reside no coração das massas [...]. Falamos principalmente no terreno varzeano, para quem, tanto o núcleo dos camisa verde, quanto o núcleo dos calções negros, ascenderam à alturas descommunaes no futebol destas plagas. É a consagração da várzea. ${ }^{107}$

Afora a evidente articulação do universo varzeano à partida entre os dois clubes incorporados ao futebol oficial - no mesmo sentido do subtítulo da seção varzeana: os que hoje são promessas, amanhã se tornarão campeões -, é interessante entrever com que elementos A Gazeta começava a construir seu discurso sobre o universo da várzea. Ela destaca, primeiramente, o fato de que os varzeanos são também entendidos; e em seguida emenda uma crítica ao universo da elite, afirmando que é nos subúrbios que estão os verdadeiros esportistas.

Ainda no mesmo ano, o periódico organiza um ranking com os 12 melhores times da várzea e ocupa duas páginas com as fotos dos primeiros quadros desses times ${ }^{108}$ sob o seguinte texto:

A 'Gazeta Esportiva' publica, de accordo com o prometido, a pagina ilustrada dos doze astros. É uma justa homenagem aos valentes quadros que sustentam o bastão dos 'leaders' do futebol varzeano. Agremiações sympathicas, com um passado belíssimo, repleto de feitos que valeram grandes honrarias; outros, quadros novos, mas, egualmente fortes e decididos, todos elles tem sabido se impor pela alta classe de sua techinica robusta e, também, pela disciplina que impera, inquebrantável, em toda a linha. Clubes correctos, não desmereceram, até agora, a escolha para a lista

\footnotetext{
107 A Gazeta Esportiva, 12 mai. 1930.

${ }^{108}$ Casale Paulista, do Cambuci; São Cristóvão, do Brás; Black Botton, da Mooca; Villa Mazzei C.A., da Villa Mazzei; E.C. Santana, de Santana; Juventus Paulista, do Canindé; Feira Livre; Horizonte F. C., do Glicério; Radium A.C., de Santana; Penhense C.A., da Penha; Paulista F.C., da Aclimação; Tupy F.C.
} 
dos doze famosos. Batalham com ardor, conquistando victorias convincentes. Brilham. E os seus feitos são acompanhados pelos demais núcleos que, cheios de vontade, estão pugnando sua entrada triumphal no rol dos 'primus inter-pares', vivendo, assim, o futebol extra official, uma phase interessantíssima de progresso. ${ }^{109}$

O texto é rico em elogios à disciplina dos varzeanos, sugerindo que a adequação daquele futebol ao modelo oficial foi também um dos elementos mobilizados pela folha na construção de sua imagem. Essa adequação, não se pode esquecer, vinha sendo pregada havia alguns anos pelos primeiros especialistas, entre os quais figurava Leopoldo Santana. Além de chefiar a redação do periódico e escrever biografias de jogadores, Santana era autor frequente de manuais organizados para apresentar as verdadeiras regras do futebol association. Em agosto de 1930, ele propagandeava a segunda edição das "Regras officiaes do futebol associação. Revista e augmentada, sahira quinta-feira", com regras "traduzidas, annotadas e illustradas por Leopoldo Sant'Anna, chefe da secção esportiva da Gazeta". ${ }^{110}$

Uma semana depois, a folha publica que o União Futebol Clube, da Barra Funda, não só se propôs a comprar a nova edição, como anunciava seu intuito de estudar as regras junto aos associados em sua sede social. ${ }^{111}$ Não se pode aqui deixar de levantar a hipótese de que o União Futebol Clube citado pelo periódico fosse o mesmo que revelou os dois craques negros em 1901, o que traria ainda mais força para a percepção da convergência e do ajuste criados por A Gazeta.

Assim, um universo varzeano bastante adequado ao modelo oficial de futebol association era então apresentado pela folha. Mas, ao mesmo tempo, em nome da tradição, não deixou de reportar costumes dos jogadores de várzea, mesmo aqueles que mais reprovava:

\footnotetext{
${ }^{109}$ A Gazeta Esportiva, 3 ago. 1930.

${ }^{110}$ Ibid.

${ }^{111}$ Ibid., 24 ago. 1930.
} 
o campeão no. 1 da várzea paulistana perdeu para o Andarahy F.C. na própria cancha da Penha. Um batalha entre quadros genuínos representantes do soccer de terra-batida. Enthusiasmo épico. Houve até o sururu, tão ao sabor carioca, entremeado de tabefes e arranhadellas pela cara. [...] já foi lemma, nos campos da várzea, os rolos de grande calibre. Antigamente, jogo algum tinha importânica si, entrechocar da refrega, não se registrasse o escandaloso barulho do corre-corre. A pittoresca fuga com as roupas nas mãos [...] era comum ouvir-se nos meios torcedores, finda a partida [...] gente molle, sem sangue! Si fosse comnosco, lá no buraco da onça (onde se situava o campo do cujo), amassávamos esse pessoal em três tempos. ${ }^{112}$

A folha tratava os famosos e comuns confrontos físicos como coisa do passado, a ser apenas lembrada. Afora sururus, ela também reportava as viradas:

que delícia, uma virada [...] era de vel-a. Geralmente ella se apresentava no seu extremado nervosismo, ao final de uma partida. Era de vel-a porque hoje não há mais viradas. A intolerância do código apeano acabou com a virada... essa famosa virada constituía a buliçosa esperança de uma torcida [...] não exprimia, em absoluto, recurso technico. Não se tratava de exhibição de uma energia industriadamente accumulada no tempo inicial para ser aproveitada em último arranco. Energia existia, sim. Mas energia caracterizada pelos desdobramentos dos membros que se projectavam pelo corpo do adversário [...] não era mais que a prática do futebol canella, do futebol velho. ${ }^{113}$

Além de revelar em que consistiam as viradas - confrontos ocorridos ao final das partidas, provavelmente em face de resultados desfavoráveis -, o artigo oferece elementos para compreender o que representava o futebol velho para o autor e para o periódico: uma forma de empenhar energia que não exprimia recurso técnico, isto é, tratava-se de energia física não controlada, tal como os gestos dos canelas negras, denunciando certas permanências discursivas dos jornalistas esportivos em relação aos populares.

O texto assumia, ainda, um tom didático ao afirmar o que significava, em termos futebolísticos modernos, tomar parte em viradas e ao descrever como se deveria proceder caso elas voltassem a acontecer:

o regulamento das penas acabou com as viradas [...] reprimida, pois, e com elegância a manifestação da virada que tingia sempre de vermelho delirante

\footnotetext{
${ }^{112}$ A Gazeta Esportiva, 17 ago. 1930.

${ }^{113}$ Ibid., 24 ago. 1930.
} 
as canellas dos artistas. [...] a polícia, segundo consta, e com sólidos fundamentos, está seriamente empenhada em punir com rigor os perturbadores da ordem nos campos de futebol. [...] estão, pois, avisados, os que ainda acreditam em viradas. ${ }^{114}$

Ou seja, praticar o futebol com virada tornara-se caso de polícia. Além da referência ao controle dos corpos dos varzeanos - já entrevista pelo poder público, no caso das doenças pestilenciais -, há outros dois aspectos interessantes na oposição entre o velho e o novo futebol apresentada pelo periódico. O primeiro deles é que o novo estava identificado com um padrão de gestos futebolísticos baseado em alegada técnica; o segundo consiste na referência ao rebuliço da torcida, sempre ansiosa por uma virada, indicando a cumplicidade entre torcedores e jogadores em relação aos sentidos de uma partida. A Gazeta também noticiou eventos como o casados contra solteiros, ainda que tentasse reduzir o impacto que a modalidade representava no bairro:

Realiza-se hoje, às 8 da manhã, no campo dos Dragões Paulistas F.C., o ansiosamente esperado encontro futebolístico entre as 'adestradíssimas' turmas de Casados e Solteiros do [bloco dos vinte e um]. Em disputa, um barril contendo 50 litros de chopps, da Antarctica. ${ }^{115}$

O uso do superlativo não deixa dúvidas quanto à tentativa de alterar a conotação do volume de chopp disputado na partida, o que provavelmente seria partilhado em um dos bares do bairro.

Já os festivais foram contemplados pelo periódico em notas como a seguinte: “A.A.Anhanguera X União Esportivo. Tomando parte no grandioso festival do Lusitano, o Anhanguera venceu por 3 a 0 , pontos de Barthô, abiscoitando assim uma bela taça". ${ }^{116} \mathrm{O}$ evento varzeano fora anunciado no início de 1932, poucos meses após a folha oferecer um gigantesco campeonato para os times suburbanos: a Taça São Paulo, que contou com a

\footnotetext{
114 Ibid.

${ }^{115}$ A Gazeta Esportiva, 10 ago. 1930.

${ }^{116}$ Ibid., 11 abr. 1932.
} 
participação de 197 times, 5.910 jogadores e teve a duração de quatro meses. ${ }^{117} \mathrm{~A}$ concomitância entre as duas modalidades de disputa dá margem a uma comparação: de um lado estava o festival realizado no bairro, em provável comemoração de data importante para o clube promotor, que se colocava ao lado de associações a ele simpáticas; de outro, o campeonato da cidade, centralizado, com quase duas centenas de clubes que disputaram partidas entre totais desconhecidos, na maior parte das vezes. A Taça São Paulo figurava como mais um dos grandes eventos culturais e esportivos promovidos ou patrocinados pela folha, que tinha na Corrida de São Silvestre, iniciada em 1925, seu exemplo mais eloquente.

Os anos 1930, sobretudo sua primeira metade, representaram o momento em que a imprensa esportiva, liderada por A Gazeta Esportiva, iniciou a produção de um novo discurso sobre a várzea em sua busca pelo futebol popular - e também moderno - com o qual desejava se identificar. No caso específico daquele periódico, isso se deu a partir da apropriação de práticas e valores construídos na várzea, reportados por jornalistas do periódico e, sobretudo, pelos próprios varzeanos. Essa é a razão pela qual circulava em suas folhas mesmo aquilo que ela reprovava, como os costumeiros confrontos físicos.

Apresentar sururus e viradas como coisas do passado tornou-se, então, uma solução para equilibrar a tradição e a modernização necessárias à imagem que se queria da várzea, à qual o periódico se referiu, ainda em 1930, da seguinte maneira:

ao futebol varzeano devemos prestar toda assistencia possível porque com elle surgirá uma mocidade forte e sadia, culta nos limites do possível e patriótica, que saberá formar a ala defensiva de nossa nacionalidade. A varzea, além de dar a nota da sensação do actual momento esportivo, está fadada a ser ainda um dos grandes factores da nossa cultura, pois é preparando bem os alicerces - o povo representado em sua classe modesta que teremos uma construção majestosa e deveras notável. ${ }^{118}$

\footnotetext{
${ }^{117}$ Para cobri-lo, A Gazeta alterou, inclusive, seu ritmo de trabalho, circulando extraordinariamente todos os dias da semana para melhor atender seus participantes.

${ }^{118}$ A Gazeta Esportiva, 24 ago. 1930.
} 
O excerto sintetiza o modo como A Gazeta Esportiva se posicionou diante da várzea, do mercado editorial e, em última análise, do projeto político para São Paulo e para o Brasil nos primeiros anos da década de 1930, projeto este que, como vimos, não se coadunava exatamente com aquele empreendido por Getúlio Vargas. Daí que, para esse periódico, as consequências da Revolução Constitucionalista de 1932 foram um pouco mais graves. Além da interrupção nas reportagens sobre a várzea, os desdobramentos do evento levaram ao:

encerramento da primeira fase de crescimento do jornal [...] com a invasão e destruição de suas instalações por partidários de Getúlio Vargas. Nos dois anos seguintes, até 1934, A Gazeta voltaria a passar por dificuldades e Cásper Líbero permaneceria parte do período no exílio, temendo maiores represálias do regime. ${ }^{119}$

O suplemento esportivo voltaria a circular com regularidade somente após aquele momento, estando já um tanto remodelado. As páginas exclusivas da seção Nas várzeas e nos subúrbios desapareceram, embora seu lema - os que hoje são promessas, amanhã se tornarão campeões - ainda servisse de guia para as notícias sobre a várzea. Não se pode esquecer que o futebol oficial tornava-se, enfim, profissional e que, em 1934, Cásper Líbero e suas folhas teriam outro posicionamento perante o governo varguista, transformando-se, pouco a pouco, em seus aliados.

A situação não parece ter alterado o discurso integrador do periódico em relação ao futebol e à várzea, que continuava figurando como um elemento fundamental na construção da noção de futebol popular em um viés paulista e paulistano. Embora o espaço a ela dedicado tenha se tornado bem diminuto após a revolução, a várzea continuou a ser noticiada em contiguidade com o futebol profissional, como lugar que a este fornecia bons jogadores: $o$ celeiro de craques. Tal imagem só pode ser compreendida em meio à construção de um novo universo amador. Se o futebol paulistano vivia sob o confronto entre amadorismo e

\footnotetext{
119 JAYO, Martin. Trajetória e idéias de Cásper Líbero, cit.
} 
profissionalismo até seu abandono pelos clubes de elite, é em meados dos anos 1930, por influência d'A Gazeta, que a relação entre esses universos toma a forma de um congraçamento, tão caro ao projeto político de então.

Não se pode deixar de dizer que tal congraçamento representava a base do discurso nacionalista que vinha sendo estabelecido não apenas pelo Estado Varguista e pela imprensa, mas também por vários segmentos da sociedade. O futebol tornou-se um elemento central desse discurso por inúmeras razões. Uma delas se refere ao fato de que os representantes desses universos "podiam se identificar com a nação simbolizada por jovens que se destacavam no que todo homem gostaria de ser: bom naquilo que faz", ${ }^{120}$ o que alcançaria seu nível máximo de significação nas Copas do Mundo de futebol justamente a partir de 1930 . Aos populares, o esporte possibilitava a representação de um universo não ligado ao trabalho, mas ao seu tempo próprio. ${ }^{121}$ No caso do futebol varzeano, há que se lembrar também dos conteúdos vinculados à rotina associativa, à condição de vida e ao estatuto do imigrante, também repertoriados pela referida folha. A base social que sustentava as associações varzeanas assume, assim, importância e visibilidade justamente por meio do futebol.

Paralelamente à contribuição em discursos e projeto nacionais, os varzeanos e suburbanos continuavam a buscar formas de organização de seus clubes. Em 1937, eles tentavam criar uma federação com o apoio do sindicato dos comerciários e de vereadores, como Achiles Bloch da Silva. ${ }^{122}$ Enquanto isso, valiam-se das novas tecnologias para usufruir do futebol: a várzea iluminava-se com a instalação de refletores em seu campos.

\footnotetext{
${ }^{120}$ HOBSBAWM, Eric. Nações e nacionalismo desde 1780. Rio de Janeiro: Paz e Terra, 1990, p. 171.

${ }^{121}$ De acordo com Denaldo Souza, o futebol seria, ainda, o espaço de resistência "de uma ética do não-trabalho que tinha suas origens no período escravocrata, quando o ato de trabalhar adquiria toda a sua negatividade" (SOUZA, Denaldo Alchorne de. O Brasil entra em campo!..., cit., p. 139). Ainda para o autor, Leônidas da Silva, jogador mundialmente conhecido como o inventor da bicicleta, partilhou desse universo dentro e fora de jogo, representando "a transgressão à ordem vigente, por não aceitar os valores e a disciplina impostos de cima. Mas [ele] também era a esperança de reconstruir um mundo melhor, por se identificar ao lazer e à alegria" (p. 141). E é sobre tais características que se assenta a construção do mito do jogador.

${ }^{122}$ A Gazeta Esportiva, 18 out. 1937.
} 
O Anhanguera, por sua vez, estava instalado num campo da Av. Rudge, bem próximo à cocheira da fábrica União do Açúcar e da Repartição de Águas e Esgotos da cidade. Num momento em que a Barra Funda industrializava-se, o clube continuava realizando, por meio de seus diretores esportivos, a escalação de seus times de futebol nas noites de sexta-feira, enquanto seus associados bebiam e jogavam a passatella. Ao mesmo tempo, ele se tornava cada vez mais famoso pelos bailes que oferecia aos finais de semana tanto na sede social, ainda situada à rua que lhe emprestava o nome, quanto nos cinemas que se espalhavam pela cidade. Barthô atuaria pelo quadro principal e pelo quadro juvenil do clube rubro-negro até o ano de 1938. 


\section{CONSIDERAÇÕES FINAIS}

O melhor começo é o seu fim [...] o problema é saber se já foi ou se ainda é começo.

Luiz Tatit

Quando o futebol passou a ser praticado em São Paulo, a cidade apenas começava a conhecer o impacto das transformações decorrentes de sua urbanização acelerada, do advento da República, do fim da escravidão e do desembarque de milhares de imigrantes associado a um incipiente processo de industrialização. Materializadas com a chegada de novos costumes, tais transformações produziam nos citadinos as sensações de atualidade e de simultaneidade, de que todos viviam, ao mesmo tempo e da mesma maneira, as mesmas experiências.

É em meio a esse universo que o esporte se insere na cidade, o que o torna um ícone desses novos e modernos tempos. No entanto, ele próprio seria um dos responsáveis por revelar que, passadas as impressões iniciais de se estar em compasso com incessantes novidades, a apropriação e o consumo de elementos culturais como os esportes e os novos entretenimentos davam-se sob formas bastante peculiares e heterogêneas.

No que se refere ao futebol, é fácil imaginar que os diferentes grupos que começavam a tomar forma na cidade também se relacionassem de maneira diferenciada com o esporte. Basta considerar o fato de que moravam e trabalhavam em suas diferentes regiões, que viviam de maneira praticamente $\operatorname{apartada}^{1}$ e que usavam o tempo livre a partir de recursos materiais, simbólicos e mesmo corporais muito diferentes. Norbert Elias e Eric Dunning atentam para tal questão ao afirmar que: "fala-se frequentemente de um jogo de futebol como se tratasse de

\footnotetext{
${ }^{1}$ Embora as ruas estivessem cada vez mais movimentadas, afora o triângulo central e os tabuleiros de xadrez dos novos bairros residenciais - "uma denominação da nova geometria que se impõe a um dos únicos trechos residenciais e 'nobre' da cidade de então. Tabuleiro, com direito a: 'reis', 'rainhas', 'bispos' e 'cavalos" - os demais espaços não eram compreendidos como sendo da cidade, sobretudo as regiões de várzea dos rios da cidade" (GAMA, Lúcia Helena. Sociabilidade e produção cultural..., cit., p. 42).
} 
algo que existisse fora ou de maneira independente do grupo de jogadores". ${ }^{2}$ Na mesma linha, Franco Júnior identifica que, nos primeiros anos do século $\mathrm{XX}$, havia ao menos duas concepções de futebol no Brasil. A primeira delas foi por ele compreendida como uma “perspectiva da pedagogia europeia. Harmonia dos músculos, higienização dos corpos, etiqueta, coordenação dos movimentos e controle da violência seriam elementos a contribuir para o fortalecimento moral e solidário dos futuros dirigentes do país". 3 Já a segunda concepção consistiria na experiência de "corpos adestrados no trabalho braçal e habituados aos folguedos das danças populares e a toda sorte de improvisação [...] vinculadas às precárias condições de vida"4 que, no entanto, "viriam a ser determinantes na sua maneira de jogar futebol". 5

Assim, embora o futebol tenha igualmente empolgado e engajado representantes dos mais diversos segmentos sociais, revelando, nessa medida, seu apelo urbano e integrador, ele foi recebido por um meio sociocultural fragmentado, baseado em experiências muito diferentes entre si tanto em relação às condições materiais de vida e à apropriação do espaço urbano quanto aos usos dos corpos. Essa pluralidade de experiências, imbricada em diferenças e desigualdades socioeconômicas, acabou por oferecer ao esporte conteúdos variados. O assunto, aliás, merece maiores investigações, sobretudo na movimentada década de 1930.

Pesquisar a produção cultural envolvendo o futebol na São Paulo daquela época, entretanto, não é tarefa fácil, principalmente se a porta de entrada for o futebol não oficial, caso de nosso objeto de pesquisa: um clube de futebol de várzea. Ainda assim, a empreitada se mostra cada vez mais necessária. A sobrevivência do Anhanguera e a documentação encontrada permitiram que a pesquisa adentrasse o desconhecido universo do futebol não oficial, possibilitando conhecer as formas de apropriação do espaço urbano por uma

\footnotetext{
${ }_{3}^{2}$ Sport et civilisation: la violence maîtrisée. Paris: Éditions Fayard, 1994, p. 262, tradução nossa.

${ }^{3}$ A dança dos deuses..., cit., p. 64.

${ }^{4}$ Ibid., p. 65.

${ }^{5}$ Ibid.
} 
específica parcela da população, bem como algumas de suas contribuições para a organização do campo esportivo de São Paulo. Para tanto, o trabalho se debruçou sobre a vida cotidiana e acompanhou a trajetória de um clube nascido em meio a ítalo-brasileiros na várzea da Barra Funda entre o fim dos anos 1920 e o fim da década seguinte. O período, que concentra uma série de tensões urbanas e culturais tornadas mais agudas no governo de Getúlio Vargas, carrega também os desdobramentos da construção, coletiva e difusa, de um discurso em torno da identidade nacional.

Embora não deixasse de partilhar esse amplo universo de questões, a comunidade imigrante instalada na Barra Funda de baixo parecia estar mais envolvida com suas demandas locais vinculadas ao cotidiano do bairro. Seus integrantes viviam, por exemplo, o delicado jogo entre desenraizar-se e enraizar-se culturalmente. Ainda procurando o domínio de uma cultura comum, eles encontraram no futebol uma forma de integrar-se. Tal como o cinema, o teatro, a dança e a música, o esporte era vivido como uma atividade de bairro, vivida de forma coletiva pela comunidade ali situada.

Um amplo engajamento comunitário fazia-se necessário para a organização de tais práticas nos clubes recreativos. Os clubes de futebol exigiam de associados e diretores, por exemplo, habilidades para negociar com os moradores e com o poder público a utilização de espaços (sub)urbanos para a prática do esporte. Tais trâmites revelam em que medida se dava a apropriação física e simbólica do espaço varzeano pelos ítalo-brasileiros e seus clubes, uma vez que a informalidade e o trato privado da coisa pública representavam sua forma mais corriqueira.

Essas são algumas das razões que permitem afirmar que as referidas práticas não estiveram relacionadas apenas a uma suspensão do trabalho para descanso e relaxamento, como em geral se afirma na utilização de categorias como lazer e entretenimento para se referir ao tempo livre dos populares. Tratava-se, ao contrário, de um forte trabalho coletivo 
para usufruir desse tempo de não trabalho. Como sugere a pesquisadora Odette Seabra, tal situação caracterizava, em verdade, a criação de um tempo-espaço próprio, qualificado a partir de práticas ligadas ao prazer. A identidade estava, pois, concentrada em atividades cujas modalidades e tempos não coincidiam com aquelas ligadas ao universo do trabalho.

Ao explorar o cotidiano do Anhanguera, sobretudo entre os anos 1928 e 1934, foi possível identificar o repertório cultural por meio do qual o esporte foi recebido entre os ítalobrasileiros da Barra Funda. Ainda que o Anhanguera tenha dialogado, em vários momentos, com o universo oficial, principalmente via imprensa, o clube se voltou menos para o modelo de organização clubística do association inglês do que para o das associações recreativas e de socorro mútuo há muito tempo presentes na várzea do Rio Tietê.

Característico das comunidades imigrantes, tal associativismo representava um modo de vida fundado na organização social coletiva, muitas vezes familiar, o que explica não apenas os negócios e os arranjos econômicos com base nesses laços - que incluíam as próprias associações esportivas -, mas também a série de soluções caseiras para os problemas do dia a dia. O futebol foi, assim, incorporado a um núcleo de práticas, valores e sentidos já em andamento na maior parte das associações populares.

Ainda por meio da dimensão cotidiana, acompanhamos a maneira pela qual os integrantes do clube, individualmente considerados, empreendiam seu tempo no esporte. Tratava-se de uma forma de se divertir e de auferir pequenos lucros, sobretudo para os mais jovens. Em diálogo com a febre futebolística que promovia valores relacionados à ação física e à juventude, os jogadores criavam mecanismos para usufruir ao máximo da experiência esportiva, mesmo que isso contrariasse a base dos vínculos com os clubes: a fidelidade. A competência esportiva e a notoriedade eram alguns desses valores, os quais, associados aos do incipiente mercado do esporte, produziram uma série de conflitos tanto para o Anhanguera, quanto para certos clubes de elite. No Paulistano, por exemplo, no início da década de 1930, 
tais valores abalaram a defesa do amadorismo e figuraram como razão para a desistência de seguir oficialmente com o esporte. No Anhanguera, eles mantiveram-se como tensões que não desestruturaram o clube. Em verdade, anos depois, ele viria a se beneficiar dessa circulação de jogadores não apenas devido aos seus recibos.

Simultaneamente, A Gazeta Esportiva entrava no mercado editorial reivindicando um lugar para aqueles a quem chamava de os verdadeiros esportistas da cidade: o povo, categoria na qual incluía a classe média, em formação naquele momento. Desde seu surgimento, o periódico se posiciona em defesa do futebol amador e da pacificação do futebol paulista, isto é, posiciona-se pelo fim da cisão entre LAF e APEA em prol da profissionalização. Nessa linha, Cásper Líbero, Leopoldo Santana e Thomaz Mazzoni desempenham papel fundamental na articulação dos clubes varzeanos à folha, iniciativa por eles bem recebida.

O futebol praticado na várzea passou, então, a ser noticiado com muito destaque em $A$ Gazeta. Nela, a modalidade figurava, ao mesmo tempo, como representante de um futebol tradicional e moderno. Era do que a folha necessitava para a construção de seu discurso sobre São Paulo. Raízes e energia oriunda do povo tornavam-se, assim, os motores da cidade, que já vinha sendo chamada de a "locomotiva" do país. Assim, para o periódico, imigrantes e ítalobrasileiros não eram apenas constitutivos do povo paulista, mas passavam a figurar como um de seus principais representantes. Essa associação parece explicar a valorização do futebol varzeano. Nascia então uma categoria de futebol associada ao povo que vivia às margens dos dois principais rios da cidade.

A opção do periódico acabou por trazer visibilidade para a rica experiência associativa que sustentava a prática esportiva dos varzeanos. Estes inclusive partilharam do trabalho do jornal, ao produzirem em pareceria com jornalistas os textos sobre seus clubes. Essa cooperação teve vários desdobramentos. Entre 1928 e 1934, por exemplo, o futebol varzeano foi pintado com cores mais suaves quando o assunto era a violência e a disciplina em campo. 
Com isso, o futebol varzeano foi sendo integrado ao campo esportivo em A Gazeta como o representante de um novo amadorismo - popular e moderno - que contrastava com o futebol profissional, embora a ele se relacionasse como fornecedor de jogadores.

Assim, a pesquisa revela que as transformações culturais oriundas de processos como a acelerada urbanização da cidade, a formação do campo esportivo ou a centralização do poder político nos anos 1930 incidiram sobre o clube Anhanguera. Destacam-se as tentativas de homogeneização social no espaço urbano, empreendidas tanto em nível local, por meio de planos urbanísticos municipais em muito baseados na exclusão ou na repressão de segmentos sociais populares, quanto pelas ações integradoras do Governo Vargas.

Revela também que experiências como as dos ítalo-brasileiros do Anhanguera não só não desapareceram a despeito dessas ações, como forjaram parte substancial do repertório material e simbólico com que o futebol foi construído na cidade de São Paulo. 


\section{ACERVOS E FONTES CONSULTADAS}

\section{Acervos particulares}

1.1. Guias, manuais, almanaques, crônicas

BRANCO, Frederico. Postais paulistas. São Paulo: Senac, 2002.

CORREA, Floriano P. Grandezas e misérias do nosso futebol. Rio de Janeiro: Flores e Maro, 1933.

DI RISIO, Donato. Il manuale della passatella. Roma: Prospettiva Editrice, 2003.

FIGUEIREDO, Antonio. História do foot-ball em São Paulo. São Paulo: O Estado de S. Paulo, 1918.

GAY, Guy. Diccionario do futebol associação. 2. ed. Rio de Janeiro: Civilização Brasileira, 1932/1933.

MACHADO, Alexandre Marcondes. La divina encrenca. 1993. Disponível em: <http:// bananere.art.br/increnca.html>. Acesso em: 26 jan. 2012.

MACHADO, Antônio de Alcântara. Brás, Bexiga e Barra Funda. São Paulo: Moderna, 2004.

MAZZONI, Thomaz. Almanaque esportivo. São Paulo: Agência Soares, 1931.

NICOLLINI, Henrique. Tietê: o rio do esporte. São Paulo: Phorte Editora, 2001.

PERELMUTTER, Daisy. Um Bom Retiro. São Paulo: Sesc, 2011.

SANTANA, Leopoldo. História do foot-ball em São Paulo: notas crítico-biográficas. São Paulo: Piratininga, 1918.

SANTANA, Leopoldo et al. Concurso comemorativo do $60^{\circ}$ aniversário da introdução do futebol em São Paulo. São Paulo: Federação Paulista de Futebol, 1954.

SCLIAR, Salomão; RIBEIRO, Mauro O. A história ilustrada do futebol brasileiro. v. I, II, III e IV. São Paulo: Edobras, 1968.

VENDITTI, Antonio. Un'istituzione romana: il gioco della Passatella. Disponível em: <http://www.specchioromano.it/fondamentali/Lespigolature/2003/GENNAIO/Un\%E2\%80\%9 9istituzione\%20romana\%20\%20\%20il\%20gioco\%20della\%20Passatella.htm>. Acesso em: 16 abr. 2012. 


\section{Acervos de clubes}

\subsection{Associação Atlética Anhanguera}

- Livro de Atas da Associação, 1928-1934.

- Livro de Atas da Associação, mai./jun./jul. 1955.

- Livro de Atas da Associação, jan./fev./mar. 1981.

- Documentos de posse de diretorias.

- Fotografias de sócios, 1930-1958.

- Fotografias de bailes sociais e jogos da associação, 1928-1958.

- Propostas para admissão de sócios, 1933-1940.

- Registros de associados, 1945-1958.

- Atas do Conselho Distrital da Barra Funda, jun. 1955.

- $32^{a}$ Revista da A. A. Anhanguera, jan. 1960.

- $37^{a}$ Revista da A. A. Anhanguera, jan. 1965.

- Taças e troféus, 1928-1958.

\subsection{Clube Atlético Paulistano e Esporte Clube Pinheiros}

- Resumo Histórico do Club Athletico Paulistano. Secção de obras do Estado de São Paulo, 1918.

- Álbum do centenário: 1899-1999 (Esporte Clube Pinheiros, São Paulo, 1999).

- Sport Club Germânia, 1899-1924.

- Sport Club Germânia, 1899-1929.

- Revista do Campeonato Paulista de Futebol de 1943.

- Sport Club Germania, 1899-1949 / Esporte Clube Pinheiros.

- Revista do Esporte Clube Pinheiros: De Hans Nobiling à IV Cadíada: 85 anos de um grande clube, 1984.

- Clube Athletico Paulistano: corpo e alma de um clube centenário, 2000.

\section{Acervo da Federação Paulista de Futebol}

\subsection{Periódicos}

- A Gazeta, 1928-1958.

- A Gazeta Esportiva.

- A Gazeta Esportiva Ilustrada (em fascículos), 1958-1959.

- Legislação da Confederação Brasileira de Desportos.

\section{Arquivo Municipal Washington Luís}

\subsection{Biblioteca}

ANNAES DA CAMARA MUNICIPAL DE SÃO PAULO. São Paulo: Ferrari \& Losasso, 1925. 
ARQUIVO DO ESTADO (SÃO PAULO). Arquivo em imagens, n. 2. São Paulo, [ca.1999]. 176 p. (Série Última Hora: Futebol)

CADERNOS Cidade de São Paulo: estádios. 2. ed. São Paulo: ICI, 1994.

ESTÁDIO Municipal de São Paulo: catálogo-programa dos festejos inaugurais. São Paulo, 16 mar. 1940.

PACAEMBU. Exposição realizada na Oficina Cultural Oswald de Andrade. São Paulo, jun. 1999.

SÃO PAULO 450 anos. São Paulo: IMS, 2004. 491 p.

\section{Arquivo do Estado de São Paulo}

\subsection{Periódicos}

- O Estado de S. Paulo, 1928-1958.

- Folha da Manhã, 1928-1958.

\section{Biblioteca Mário de Andrade}

\subsection{Mapoteca}

- Planta da cidade de São Paulo mostrando todos os arrabaldes e terrenos arruados, 1924.

- Planta da cidade de São Paulo feita pela Diretoria de Obras e Viação, 1929.

- Planta da cidade de São Paulo feita pela Repartição de Águas e Esgotos,1929.

- Mapa de Expansão da Área urbanizada da Região Metropolitana de São Paulo, 1915/1929.

- Planta dos distritos de São Paulo, 1943-1944.

- Guia e mapa da cidade de São Paulo, 1968.

\subsection{Setor de obras raras}

CARDIM, Mario. Guia do football. São Paulo: Cardoso, 1906.

MAZZONI, Thomaz. História do futebol no Brasil (1894-1950). São Paulo: Edições Leia, 1950.

\subsection{Coleção São Paulo}

HISTÓRIA da Barra Funda (documentário) In: História dos bairros de São Paulo. Direção: Rogério Soares. São Paulo: Prefeitura de São Paulo, 2006. DVD (26’).

SOARES, Dulce. Barra Funda: esquinas, fachadas e interiores. São Paulo: Imprensa Oficial, 1982. 


\section{Entrevistas}

- Sr. Pôncio, em 22 de maio 2009.

- Sr. Walter Dias, em 22 de maio de 2009.

- Sr. José Carlos Bertolozzi, em 24 de abril de 2010.

- Sr. Nelson Manoel, 24 de abril de 2010.

- Sr. William João Sandonato, em 23 de maio de 2010.

- Sr. Augusto Pereira Neto (Carioquinha), em 12 de fevereiro de 2011.

- Sr. Cirilo Magalhães, em 12 de fevereiro de 2011.

- Sr. Jacó Kuperman, em 13 de março de 2011.

- Profa. Dra. Odette Seabra, em 20 de junho de 2011.

- Arthur Tirone e "Grego", 25 de junho de 2011.

- Sr. Salathiel Fernandes da Silva, em 19 de junho de 2011.

- Ângelo Tirone, Arthur Tirone e Sr. Clodoaldo, em 28 de agosto de 2011.

- Sr. Pedro Cardoso, entre agosto e setembro de 2012, por correio eletrônico.

\section{Documentos oficiais}

BRASIL. Decreto-Lei $n^{0} 1.545$, de 25 de agosto de 1939. Dispõe sobre a adaptação ao meio nacional dos brasileiros descendentes de estrangeiros. Diário Oficial da União, Brasília, seção 1, 28 jul. 1939. Disponível em: <http://www6.senado.gov.br/legislacao/Lista Publicacoes.action?id=11345>. Acesso em: 30 jan. 2012.

\section{Fontes secundárias}

- Depoimentos recolhidos na página eletrônica do Museu da Pessoa: Sr. Carlos Laporta; Gervásio da Silva Freitas; Ubirajara Ferreira Diniz; Alfredo Campos. Disponível em: $<$ http://www.museudapessoa.net/historias/especiais/bras_bexiga_barra_ funda/>. Acesso em: 15 jan. 2012.

- Dados recolhidos a partir da transcrição da palestra L'Italia e l'italiano in Brasile: Tra immigrazione e attualità, ministrada pela Profa. Dra. Elisabetta Santoro na Universidade Paris X, Nanterre, em 26 jan. 2012.

- Recuperação dos dados de pesquisa demográfica sobre a população de São Paulo e de seus bairros. Prefeitura de São Paulo; disponível em: <http://smdu.prefeitura.sp.gov. br/historico_demografico>. Acesso em: 20 jan. 2012. Instituto Brasileiro de Geografia e Estatística; disponível em: <http://www.ibge.gov.br/brasil500/tabelas/imigracao_nacio nalidade_84a33.htm>. Acesso em: 22 jan. 2012.

- IBGE. Brasil: 500 anos de povoamento. Rio de Janeiro, 2000. Disponível em: <http:/ www.ibge.gov.br/brasil500/>. Acesso em: 10 jan. 2013.

- Não quero redenção, quero a Argentina! Entrevista com Arthur Tirone. Disponível em: <http://www.copa2014.turismo.gov.br/copa/copa_cabeca/detalhe/artigo_Artur_Tirone.html>. Acesso em: 17 jan. 2011.

- Depoimentos recolhidos. BOSI, Ecléa. Memória e sociedade: lembrança de velhos. São Paulo: Companhia das Letras, 1994.

- Depoimentos recolhidos. Disponível em: <http://www.aprenda450anos.com.br/450anos/ vila_metropole/2-3_bairros_operarios.asp\#>. Acesso em: 14 jan. 2012. 
- Depoimento de Ana Maria Lisbôa Mortari. Disponível em: <http://vivasp.com/texto.asp? tid=3226\&sid=1>. Acesso em: 21 jan. 2012.

- Consulta em enciclopédia eletrônica. Disponível em: <http://www.specchioromano.it/ fondamentali/Lespigolature/2003/GENNAIO/Un\%E2\%80\%99istituzione\%20romana\%20\%2 0\%20il\%20gioco\%20della\%20Passatella.htm>. Acesso em: 16 abr. 2012.

- Consulta em blog da Associação Atlética Anhanguera. Disponível em: <http://anhanguera. blogspot.com.br/>. Acesso em: 20 set. 2012. 


\section{BIBLIOGRAFIA}

\section{Teoria e metodologia da história:}

ANDERSON, Benedict. Comunidades imaginadas: reflexões sobre a origem e a difusão do nacionalismo. São Paulo: Companhia das Letras, 2007.

BAKHTIN, Mikhail. A cultura popular na Idade Média e no Renascimento. São Paulo: Hucitec, 1999.

BENJAMIN, Walter. O narrador. In: Magia e técnica, arte e política. São Paulo: Brasiliense, 1987. p. 197-221.

BERMAN, Marshall. Tudo que é sólido desmancha no ar: a aventura da modernidade. São Paulo: Companhia das Letras, 1996.

BHABHA, Homi. DissemiNação: o tempo, a narrativa e as margens da nação moderna In: O local da cultura. Belo Horizonte: UFMG, 2001. p. 198-238.

BLOCH, Marc. Apologia da história. Rio de Janeiro: Zahar, 2002.

BOSI, Ecléa. Memória e sociedade: lembranças de velhos. São Paulo: Companhia das Letras, 2007.

CHARTIER, Roger. História cultural: entre práticas e representações. Lisboa: Difel, 1990.

O mundo como representação. Estudos Avançados, São Paulo, v. 5, n. 11, p. 173191, jan./abr. 1991.

n. 16, 1995.

Cultura popular: revisitando um conceito. Estudos Históricos, Rio de Janeiro, v. 8,

CONNERTON, Paul. Como as sociedades recordam. Oeiras: Celta Editora, 1993.

DARNTON, Robert. O beijo de Lamourette: mídia, cultura e revolução. São Paulo: Companhia das Letras, 1990.

DOSSE, François. O império do sentido: a humanização das ciências humanas. Bauru: Edusc, 2003.

ECO, Umberto. Como se faz uma tese. 2. ed. São Paulo: Perspectiva, 1985. (Coleção Estudos)

FEBVRE, Lucien. Combates pela história. Lisboa: Editorial Presença, 1989.

GINZBURG, Carlo. O inquisidor como antropólogo: uma analogia e suas implicações In: A micro-história e outros ensaios. Lisboa: Difel, 1989. p. 203-214.

Mitos, emblemas e sinais. São Paulo: Companhia das Letras, 2001. 
O queijo e os vermes: o cotidiano e as ideias de um moleiro perseguido pela Inquisição. São Paulo: Companhia das Letras, 2006.

HARTOG, François. L'inquiétante étrangeté de 1'histoire. Revue Esprit: Religions et politique: séparations sous tension, fevereiro, 2011.

HELLER, Agnes. O cotidiano e a história. São Paulo: Paz e Terra, 1992.

HOBSBAWN, Eric. Nações e nacionalismo desde 1780. Rio de Janeiro: Paz e Terra, 1990.

Globalização, democracia e terrorismo. São Paulo: Companhia das Letras, 2007.

HOBSBAWM, Eric; RANGER, Terence (Orgs.). A invenção das tradições. Rio de Janeiro: Paz Terra, 1984.

KOSELLECK, Reinhardt. Futuro passado. Rio de Janeiro: Contraponto, 2006.

MEIHY, José Carlos S. B. Manual de história oral. São Paulo: Loyola, 2005.

MENESES, Ulpiano Toledo Bezerra de. A história, cativa da memória? Para um mapeamento da memória no campo das ciências sociais. Revista do Instituto de Estudos Brasileiros/USP, São Paulo, v. 34, p. 9-24, 1992.

As marcas da leitura histórica: arte grega nos textos antigos. Manuscritica, São Paulo, v. 7, p. 69-82, 1998.

Os usos culturais da cultura: contribuição para uma abordagem crítica das práticas e políticas culturais. Transcrição da conferência proferida no encerramento do Congresso Internacional de Geografia e Planejamento do Turismo, 1995.

. Fontes visuais, cultura visual, história visual: balanço provisório, propostas cautelares. Revista Brasileira de História, São Paulo, v. 23, n. 45, p. 11-36, 2003.

MORAES, José Geraldo Vinci de. História e historiadores da música popular no Brasil. Latin American Music Review, Austin-Texas, EUA, v. 28, n. 2, p. 271-299, 2007.

MUZART, Idelette; MATTOSO, Kátia de Queirós. Materiaux pour une histoire culturelle du Brésil: objets, voix et memoires. Paris: L’Harmattan, 1999. (Collection Recherches et Documents Ameriques Latines)

RICOEUR, Paul. A memória, a história, o esquecimento. Tradução de Alain François. Campinas: Editora da UNICAMP, 2007.

RIOUX, Jean-Pierre; SIRINELLI, Jean-François (Orgs.). Para uma história cultural. Lisboa: Estampa, 1998.

SARLO, Beatriz. Tempo passado: cultura da memória e guinada subjetiva. São Paulo: Companhia das Letras, 2007. 
THOMPSON, Edward Palmer. Costumes em comum: estudos sobre a cultura popular tradicional. São Paulo: Companhia das Letras, 1998.

\section{Espaco, corpo e práticas urbanas:}

BOLLNOW, Otto Friedrich. O homem e o espaço. Paraná: Editora UFPR, 2008.

CERTEAU, Michel de. A invenção do cotidiano. Petrópolis: Vozes, 2000. v. 1.

LEFEBVRE, Henri. Espaço e política. Belo Horizonte: Ed. UFMG, 2008.

LEPETIT, Bernard. A história leva os atores a sério? In: Por uma nova história urbana. São Paulo: Edusp, 2002. p. 227-244.

MAGNANI, José Guilherme C. Etnografia como prática e experiência. Horizontes Antropológicos, Porto Alegre, ano 15, n. 32, p. 129-156, jul./dez. 2009.

MAUSS, Marcel. Noção de técnica corporal. In: MAUSS, Marcel. Sociologia e antropologia. São Paulo: Cosac Naify, 2003. p. 399-422.

ORTIZ, Renato. A moderna tradição brasileira: cultura popular e indústria cultural. 5. ed. São Paulo: Brasiliense, 1994.

SAYER, Andrew. The difference that space makes. In: GREGORY, Derek; URRY, John (Orgs.). Social relations and spatial structures. Londres: Macmillan, 1985. p. 49-66.

SIMMEL, Georg. A metrópole e a vida mental. In: VELHO, O. (Org.). O fenômeno urbano. Rio de Janeiro: Zahar, 1967. p. 11-25.

\section{História da cidade de São Paulo:}

BARBUY, Heloisa. A cidade-exposição: comércio e cosmopolitismo em São Paulo, 18601914. São Paulo: Editora da Universidade de São Paulo, 2006.

BRUNELLI, Aideli S. Urbani et al. Barra Funda. São Paulo: DPH, 2006. (Série História dos Bairros de São Paulo, v. 29)

BRUNO, Ernani Silva. História e tradições da cidade de São Paulo. Rio de Janeiro: José Olympio, 1954. v. 3.

CAMPOS, Cândido M.; GAMA, Lúcia Helena; SACCHETA, Wladimir. São Paulo: metrópole em trânsito, percursos urbanos e culturais. São Paulo: Ed. Senac, 2004.

CARVALHO, Vânia Carneiro de. Gênero e artefato: o sistema doméstico na perspectiva da cultura material, São Paulo, 1870-1920. São Paulo: Edusp; Fapesp, 2008.

COSTA, Jurandir Freire. Ordem médica e norma familiar. Rio de Janeiro: Edições Graal, 1999. 
CUSTÓDIO, Vanderli. Dos surtos urbanísticos do final do século XIX ao uso das várzeas pelo Plano de Avenidas. Geosul, Florianópolis, v. 19, n. 38, p. 77-98, jul./dez. 2004. Disponível em: <http://pt.scribd.com/doc/72503805/CUSTODIO-2004-surtos-urbanisticosuso-varzeas-Plano-de-Avenidas>. Acesso em: 13 jun. 2012.

FAUSTO, Boris. O crime do restaurante chinês: carnaval, futebol e justiça na São Paulo dos anos 30. São Paulo: Companhia das Letras, 2009.

GAMA, Lúcia Helena. Nos bares da vida: produção cultural e sociabilidade em São Paulo (1940-1950). São Paulo: Ed. Senac, 1998.

Sociabilidade e produção cultural: uma caminhada pelos vértices e pela história do triângulo central. Cidade: Revista do Departamento do Patrimônio Histórico/SMC, São Paulo, ano 5, n. 5, p. 40-51, jan. 1998.

GUNN, Philip; CORREIA, Telma de B. Vilas operárias: o mundo fabril penetra na cidade. In: CAMPOS, Cândido M.; GAMA, Lúcia Helena; SACCHETA, Wladimir. São Paulo: metrópole em trânsito, percursos urbanos e culturais. São Paulo: Ed. Senac, 2004. p. 82-89.

HAAG, Carlos. A cidade dos engenheiros. Pesquisa FAPESP, São Paulo, n. 178, dez. 2010. Disponível em: <http://revistapesquisa.fapesp.br/2010/12/06/a-cidade-dos-engenheiros>. Acesso em: 15 mar. 2012.

JORGE, Janes. Tietê, o rio que a cidade perdeu: São Paulo, 1890-1940. São Paulo: Alameda, 2006.

JORGE, Janes et al. Paulicéia afro: lugares, histórias e pessoas. São Paulo: Secretaria Municipal de Cultura, 2008.

MARINS, Paulo César Garcez. Habitação e vizinhança: limites da privacidade no surgimento das metrópoles brasileiras. In: SEVCENKO, Nicolau (Org.). História da vida privada no Brasil: República: da Belle Époque à Era do Rádio. São Paulo: Companhia das Letras, 1998. v. 3, p. 131-214.

MARTINS, José de Souza. Subúrbio: vida cotidiana e história no subúrbio da cidade de São Paulo: São Caetano, do fim do Império ao fim da República Velha. São Paulo: Hucitec; Unesp, 2002.

A ferrovia e a modernidade em São Paulo: a gestação do ser dividido. Revista USP, São Paulo, n. 63, nov. 2004. Disponível em: <http://www.revistasusp.sibi.usp.br/scielo. php?script=sci_arttext\&pid=S0103-99892004000400002\&lng=pt\&nrm=iso>. Acesso em: 3 mar. 2012.

A aparição do demônio na fábrica: origens do eu dividido no subúrbio operário. São Paulo: Editora 34, 2008.

MERHY, Emerson E. O capitalismo e a saúde pública: a emergência das práticas sanitárias no Estado de São Paulo. Campinas: Papirus, 1987. 
MORAES, José Geraldo Vinci de. Sonoridades paulistanas: a música popular em São Paulo (fim do século XIX - início do século XX). Dissertação (Mestrado) - Pontifícia Universidade Católica de São Paulo, São Paulo, 1990.

Cidade e cultura urbana na Primeira República. São Paulo: Atual, 1994. (Coleção Discutindo a História do Brasil)

. Metrópole em sinfonia: história, cultura e música popular na São Paulo dos anos 30. São Paulo: Estação Liberdade, 2000.

MOTA, André. Tropeços da medicina bandeirante: São Paulo, 1892-1920. Tese (Doutorado) - Faculdade de Filosofia, Letras e Ciências Humanas, Universidade de São Paulo, São Paulo, 2001.

NOVAIS, Fernando A. (Org.). História da vida privada no Brasil. São Paulo: Companhia das Letras, 1998. v. 3 e 4.

OLIVEIRA, Maria Luiza Ferreira de. O registro dos limites da cidade: imagens da várzea do Carmo no século XIX. Anais do Museu Paulista, São Paulo, v. 6-7. p. $37-59$ (1998-1999), 2003.

PAOLI, Maria Célia; DUARTE, Adriano. São Paulo no plural: espaço público e redes de sociabilidade. In: PORTA, Paula (Org.). História da cidade de São Paulo: a cidade na primeira metade do século XX, 1890-1954. São Paulo: Paz e Terra, 2004. v. 3, p. 53-99.

PINTO, Maria Inez Machado Borges. Cotidiano e sobrevivência: a vida do trabalhador pobre na cidade de São Paulo, 1890-1894. Tese (Doutorado) - Faculdade de Filosofia, Letras e Ciências Humanas, Universidade de São Paulo, São Paulo, 1984.

PIRES, Elaine Muniz. História dos bairros paulistanos: Barra Funda. 200(?). Disponível em: <http://almanaque.folha.uol.com.br/bairros_barra_funda.htm>. Acesso em: 19 abr. 2012.

PORTA, Paula (Org.). História da cidade de São Paulo: a cidade na primeira metade do século XX, 1890-1954. São Paulo: Paz e Terra, 2004. v. 3.

PRADO JÚNIOR, Caio. A cidade de São Paulo: geografia e história. São Paulo: Brasiliense, 1989.

ROLNIK, Raquel. Cada um no seu lugar! São Paulo, início da industrialização: geografia do poder. Dissertação (Mestrado) - Faculdade de Arquitetura e Urbanismo, Universidade de São Paulo, São Paulo, 1981.

SALIBA, Elias Tomé. Cultura. In: SCHWARCZ, Lilia Moritz (Coord.). A abertura para o mundo, 1889-1930. Rio de Janeiro: Objetiva/Fundació Mapfre, 2012. v. 3, p. 239-294. (Col. História do Brasil Nação, 1808-2010)

SANTOS, Carlos José Ferreira dos. Nem tudo era italiano: São Paulo e pobreza (18901915). São Paulo: Annablume/Fapesp, 2008.

SCHMIDT, Afonso. São Paulo de meus amores. São Paulo: Paz e Terra, 2003. 
SCHPUN, Mônica Raisa. Beleza em jogo: cultura física e comportamento em São Paulo nos anos 20. São Paulo: Senac/Boitempo, 1999.

SCHWARCZ, Lilia Moritz. Retrato em branco e negro: jornais, escravos e cidadãos em São Paulo no final do século XIX. São Paulo: Companhia das Letras, 2001.

. População e sociedade. In: (Coord.). A abertura para o mundo, 1889-1930. Rio de Janeiro: Ed. Objetiva/ Fundació Mapfre, 2012. v. 3, p. 35-83. (Col. História do Brasil Nação, 1808-2010)

SEABRA, Odette Carvalho de Lima. Os meandros dos rios nos meandros do poder: Tietê e Pinheiros: valorização dos rios e das várzeas na cidade de São Paulo. Tese (Doutorado) Faculdade de Filosofia, Letras e Ciências Humanas, Universidade de São Paulo, São Paulo, 1987.

SEGAWA, Hugo. São Paulo, veios e fluxos: 1872-1954. In: PORTA, Paula (Org.). História da cidade de São Paulo: a cidade na primeira metade do século XX, 1890-1954. São Paulo: Paz e Terra, 2004. v. 3, p. 341-386.

SEVCENKO, Nicolau. Orfeu extático na metrópole: São Paulo, sociedade e cultura nos frementes anos 20. São Paulo: Companhia das Letras, 1992.

A capital irradiante, técnica, ritmos e ritos do Rio. In: (Org.). História da vida privada no Brasil: República: da Belle Époque à Era do Rádio. São Paulo: Companhia das Letras, 1998. v. 3, p. 513-618.

Tietê influenciou a formação da cidade. Folha Online Especial, 25 jan. 2001. Disponível em: <http://www1.folha.uol.com.br/folha/especial/2003/saopaulo450/artigossevcenko.shtml>. Acesso em: 2 fev. 2012.

SOUZA, Maria Adélia Aparecida de. Metrópoles e paisagem: caminhos e descaminhos da urbanização. In: PORTA, Paula (Org.). História da cidade de São Paulo: a cidade na primeira metade do século XX, 1890-1954. São Paulo: Paz e Terra, 2004. v. 3, p. 121-151.

\section{Imigracão, trabalho e associativismo:}

ALVIM, Zuleika Maria. O Brasil italiano (1880-1920). In: FAUSTO, Boris (Org.). Fazer a América. São Paulo: Edusp, 2000. p. 383-417.

ARAÚJO, José Renato de Campos. Imigração e futebol: o caso Palestra Itália. Dissertação (Mestrado em História) - Instituto de Filosofia e Ciências Humanas, Universidade Estadual de Campinas, Campinas, 1996.

Migna terra: migrantes italianos e fascismo na Cidade de São Paulo (1922-1935). Tese (Doutorado) - Instituto de Filosofia e Ciências Humanas, Universidade Estadual de Campinas, Campinas, 2003. 
BIONDI, Luigi. Entre associações étnicas e de classe: os processos de organização política e sindical dos trabalhadores italianos na cidade de São Paulo (1890-1920). Tese (Doutorado) Instituto de Filosofia e Ciências Humanas, Universidade Estadual de Campinas, Campinas, 2002.

CHALHOUB, Sidney et al. Trabalhadores na cidade: cotidiano e cultura no Rio de Janeiro e em São Paulo, séculos XIX e XX. Campinas: Ed. Unicamp, 2009.

COLBARI, Antonia. Ética do trabalho: a vida familiar na construção da identidade profissional. São Paulo: Letras \& Letras/SPDC/UFES, 1995.

FAUSTO, Boris. Negócios e ócios: histórias da imigração. São Paulo: Companhia das Letras, 1997.

Imigração: cortes e continuidades. In: NOVAIS, Fernando A. (Org.). História da vida privada no Brasil. São Paulo: Cia das Letras, 1998. v. 4.

(Org.). Fazer a América. São Paulo: Edusp, 1999.

História do Brasil. São Paulo: Edusp, 2012.

FERNANDES, Florestan. A integração do negro à sociedade de classe. São Paulo: Edusp, 1965.

FONTES, Paulo. Um nordeste em São Paulo: trabalhadores migrantes em São Miguel Paulista (1945-66). Rio de Janeiro: FGV, 2008.

GOMES, Angela de Castro. A pequena Itália de Niterói: uma cidade, muitas famílias. In: (Org.). Histórias de imigrantes e de imigração no Rio de Janeiro. Rio de Janeiro: 7 Letras, 2000. p. 66-103.

HALL, Michael. Imigrantes na cidade de São Paulo. In: PORTA, Paula (Org.). História da cidade de São Paulo: a cidade na primeira metade do século XX, 1890-1954. São Paulo: Paz e Terra, 2004. v. 3, p. 121-151.

HARDMAN, Francisco Foot. Nem pátria, nem patrão!: memória operária, cultura e literatura no Brasil. São Paulo: Editora UNESP, 2002.

HOBSBAWN, Eric. A formação da cultura da classe operária britânica. In: Mundos do trabalho: novos estudos sobre história operária. Rio de Janeiro: Paz e Terra, 2000. p. 251297.

MANFREDI, Maria Silvia. Formação sindical no Brasil: história de uma prática cultural. São Paulo: Escrituras, 1996.

REZENDE, Vinícius de. Da arte de saber fazer ao operário-boi? In: SIMPÓSIO NACIONAL DE HISTÓRIA, 26., 2011, São Paulo. Anais... São Paulo: ANPUH, 2011. Disponível em: <http://www.snh2011.anpuh.org/resources/anais/14/1300846319_ARQUIVO_Daartedesaberf azeraooperario-boi.pdf>. Acesso em: 29 mar. 2012. 
SCHPUN, Mônica Raisa. O cinema mudo em São Paulo: experiências de italianos e italianas, práticas urbanas e códigos sexuados. ArtCultura, Uberlândia, v. 9, n. 14, p. 71-81, jan.-jun. 2007.

SEIXAS, Jacy Alves de. Mémoire et oubli: anarchisme et syndicalisme révolutionnaire au Brésil. Paris: Ed. de la Maison des sciences de 1’homme, 1992.

SENNETT, Richard. A corrosão do caráter: as consequências pessoais do trabalho no novo capitalismo. Rio de Janeiro: Record, 2008.

O artífice. Rio de Janeiro: Record, 2009.

SIQUEIRA, Uassyr de. Clubes e sociedades dos trabalhadores do Bom Retiro: organização, lutas e lazer em um bairro paulistano (1915-1924). Dissertação (Mestrado) Departamento de História do Instituto de Filosofia e Ciências Humanas, Universidade Estadual de Campinas, Campinas, 2002.

Entre maxixes, peladas e palavras de ordem: associações dos trabalhadores paulistanos durante a Primeira República. Revista Esboços, Florianópolis, v. 12, n. 14, p. 7586, 2005. Disponível em: <http://www.periodicos.ufsc.br/index.php/esbocos/article/view/ 169>. Acesso em: 3 mar. 2012.

\section{Imprensa e imprensa esportiva:}

ANTUNES, Fátima M. R. Ferreira. Com brasileiro, não há quem possa: futebol e identidade nacional em José Lins do Rego, Mário Filho e Nelson Rodrigues. São Paulo: Unesp, 2004.

CAPELATO, Maria Helena. Os arautos do liberalismo: 1920-1945. São Paulo: Editora Brasiliense, 1989.

HIME, Gisely Valentim Vaz Coelho. A hora e a vez do progresso: Cásper Líbero e o exercício do jornalismo nas páginas d'A Gazeta. Dissertação (Mestrado) - Escola de Comunicações e Artes, Universidade de São Paulo, São Paulo, 1997.

Cásper Líbero entre o profissional e o mito: inventário crítico das fontes bibliográficas e hemerográficas. Revista PJ:BR: Jornalismo Brasileiro, São Paulo, n. 3, $1^{\circ}$ semestre/2004.

HOLLANDA, Bernardo B. Buarque. O clube como vontade e representação: o jornalismo esportivo e a formação das torcidas organizadas de futebol do Rio de Janeiro. Rio de Janeiro: 7 Letras, 2009.

JAYO, Martin. Trajetória e idéias de Cásper Líbero. Revista PJ:BR: Jornalismo Brasileiro, São Paulo, n. 3, $1^{\circ}$ semestre/2004.

MARQUES, José Carlos. O futebol em Nelson Rodrigues. São Paulo: Educ, 2003. 
MOTA, Carlos Guilherme; CAPELATO, Maria Helena. História da Folha de S.Paulo (1921-1981). São Paulo: Impres, 1981.

RIBEIRO, André. Os donos do espetáculo: histórias da imprensa esportiva no Brasil. São Paulo: Editora Terceiro Nome, 2007.

SILVA, Marcelino Rodrigues da. Mil e uma noites de futebol: o Brasil moderno de Mário Filho. Belo Horizonte: Ed. UFMG, 2006.

TOLEDO, Luiz Henrique de. Contribuições ao estudo da crônica esportiva 1: a "contracrônica" esportiva de Lima Barreto. Pesquisa de Campo, Rio de Janeiro, n. 3-4, p. 37-50, 1996.

\section{Futebol, sociabilidade e lazer:}

ANTUNES, Fátima M. R. Ferreira. Futebol de fábrica em São Paulo. Dissertação (Mestrado) - Faculdade de Filosofia, Letras e Ciências Humanas, Universidade de São Paulo, São Paulo, 1992.

Do velódromo ao Pacaembu: o movimento esportivo em São Paulo e a trajetória do futebol. Cidade: Revista do Departamento do Patrimônio Histórico/SMC, São Paulo, ano 5, n. 5, jan. 1998.

ARCHETTI, Eduardo P. Masculinities: football, polo and the tango in Argentina. Oxford/New York: Global Issues, 1999.

BLAY, Jean Pierre. "Qu'est-ce qu'une nation”... qui joue au football? Cahiers des Amériques Latines, Paris, n. 39, 2002/1.

Espaços urbanos, práticas físicas e sociedade esportiva na cidade do Rio de Janeiro no século XX. Revista do IHGB, Rio de Janeiro, ano 168, n. 437, p. 251-273, out./dez. 2007.

Éducation physique et culture sportive au Brésil à l'époque contemporaine: entre utilité sociale et reconaissance identitaire. Cahiers des Amériques Latines, Paris, n. 60-61, p. 115-127, 2009.

BOURDIEU, Pierre. Como é possível ser esportivo? In: Questões de sociologia. Rio de Janeiro: Marco Zero, 1983. p. 136-153.

Programa para uma sociologia do esporte. In: Coisas ditas. São Paulo: Brasiliense, 1990. p. 207-220.

CALLOIS, Roger. Les jeux et les hommes. Paris: Gallimard, 1985.

CAMPOS, Flavio de; MORAES, José Geraldo Vinci de. Como o Brasil entra em campo. Revista de História, Dossiê História e Futebol, São Paulo, n. 163, p. 129-135, 2010.

COSTA, Márcia Regina da et al. (Orgs.). Futebol: espetáculo do século. São Paulo: Musa Editora, 1999. 
COUTO, Euclides de Freitas. Jogo de extremos: futebol, cultura e política no Brasil (19301978). Tese (Doutorado em História) - Faculdade de História, Universidade Federal de Minas Gerais, Belo Horizonte, 2009.

DAMATTA, Roberto (Org.). Esporte e sociedade brasileira. In: Universo do futebol. Rio de Janeiro: Pinakotheke, 1982.

DAMO, Arlei. Do dom à profissão: a formação de futebolistas no Brasil e na França. São Paulo: Hucitec/Anpocs, 2007.

DESIDERIO, Giancristiano. Platone et calcio: Saggio sul pallone e la condizione umana. Roma: Lìmina, 2005.

DUARTE, René. Friedenreich e a reinvenção de São Paulo: o futebol e a vitória na invenção da metrópole. Dissertação (Mestrado em História Social) - Faculdade de Filosofia, Letras e Ciências Humanas, Universidade de São Paulo, São Paulo, 2008.

ELIAS, Norbert; DUNNING, Eric. Sport et civilisation: la violence maitrisée. Paris: Éditions Fayard, 1994.

FERREIRA, João Fernando. A construção do Pacaembu. São Paulo: Paz e Terra, 2008.

FLORENZANO, José Paulo. A democracia corinthiana: práticas de liberdade no futebol brasileiro. São Paulo: Educ/Fapesp, 2009.

FRANCO JÚNIOR, Hilário. A dança dos deuses: futebol, sociedade, cultura. São Paulo: Companhia das Letras, 2007.

FRANZINI, Fábio. As raízes do país do futebol: estudo sobre a relação entre o futebol e a nacionalidade brasileira (1919-1950). Dissertação (Mestrado em História Social) - Faculdade de Filosofia, Letras e Ciências Humanas, Universidade de São Paulo, São Paulo, 2000.

GIGLIO, Sérgio Settani. Representações do futebol nos jogos olímpicos e na copa do mundo. Pesquisa de doutorado em andamento. Escola de Educação Física e Esporte, Universidade de São Paulo, São Paulo, [2014].

GUEDES, Simoni Lahud. Esporte, lazer e sociabilidade. In: MARTINS, Carlos Benedito; DUARTE, Luiz Fernando Dias (Orgs.). Horizontes das ciências sociais no Brasil: Antropologia. 1. ed. São Paulo: Anpocs; Discurso Editorial; Barcarolla, 2010. v. 1, p. 431456.

HELAL, Ronaldo; SOARES, Antonio Jorge; LOVISOLO, Hugo. Mídia, raça e idolatria. Rio de Janeiro: Mauad, 2001.

HIRATA, Daniel Veloso. Futebol de várzea: um estudo sobre práticas urbanas e seus territórios. Dissertação (Mestrado em Sociologia) - Universidade de São Paulo, São Paulo, 2005 . 
HOLLANDA, Bernardo B. Buarque de. O descobrimento do futebol: modernismo, regionalismo e paixão esportiva em José Lins do Rego. Rio de Janeiro: Biblioteca Nacional, 2004.

HUIZINGA, Johan. Homo ludens: o jogo como elemento da cultura. São Paulo: Perspectiva, 2000.

JESUS, Gilmar Mascarenhas de. Construindo a cidade moderna: a introdução dos esportes na vida urbana do Rio de Janeiro. Revista Estudos Históricos, São Paulo, v. 13, n. 23, 1999. Disponível em: <http://bibliotecadigital.fgv.br/ojs/index.php/reh/article/viewArticle/2086>. Acesso em: 2 mar. 2012.

Várzeas, operários e futebol: uma outra geografia. Geographia: Revista do Programa de Pós-Graduação em Geografia da Universidade Federal Fluminense, Niterói, v. 4, n. 8, p. 84-92, 2002.

LEITE LOPES, José S. A vitória do futebol que incorporou a pelada. Revista USP, São Paulo, n. 22, p. 64-83, 1994.

MELO, Victor. Futebol e cinema: duas paixões, um planeta. In: ALVITO, Marcos; MELO. Victor (Orgs.). Futebol por todo o mundo: diálogos com o cinema. 1. ed. Rio de Janeiro: FGV, 2006. p. 9-26.

MERDRIGNAC, Bernard. Le sport au Moyen Âge. Rennes: Presses Universitaires de Rennes, 2002.

NEGREIROS, Plínio José L. de Campos. Resistência e rendição: a gênese do Sport Club Corinthians Paulista e o futebol oficial em São Paulo, 1910-1916. Dissertação (Mestrado em História) - Faculdade de História, Pontifícia Universidade Católica, São Paulo, 1992.

A cidade excludente e o clube do povo. Revista de História, São Paulo, n. 163, p. 207-242, jul./dez. 2010.

PARDINI, Melina Nóbrega M. A narrativa da ordem e a voz da multidão: o futebol na imprensa durante o estado novo (1937-1945). Dissertação (Mestrado em História Social) Faculdade de Filosofia, Letras e Ciências Humanas, Universidade de São Paulo, São Paulo, 2009.

PEREIRA, Leonardo. Footballmania: uma história social do futebol no Rio de Janeiro, 19021938. Rio de Janeiro: Nova Fronteira, 2000.

RAGO, Margareth. A invenção do cotidiano na metrópole: sociabilidade e lazer em São Paulo, 1900-1950. In: PORTA, Paula (Org.). História da cidade de São Paulo: a cidade na primeira metade do século XX, 1890-1954. São Paulo: Paz e Terra, 2004. v. 3, p. 387-435.

REVISTA USP. Dossiê Futebol. São Paulo: USP, n. 22, 1994.

RODRIGUES FILHO, Mario. O negro no futebol brasileiro. Rio de Janeiro: Mauad, 2003. 
ROSENFELD, Anatol. O futebol no Brasil. Revista Argumento, Rio de Janeiro, ano I, n. 4, 1973.

Negro, macumba e futebol. 1. ed. São Paulo: Perspectiva, 2000.

SALUM, Alfredo Oscar. Palestra Itália e Corínthians: quinta coluna ou tudo buona gente? Tese (Doutorado em História) - Faculdade de Filosofia, Letras e Ciências Humanas, Universidade de São Paulo, São Paulo 2007.

SANTOS, Marco Antonio da Silva. Futebol de várzea como espaço de sociabilidade. Dissertação (Mestrado em Ciências Sociais) - Faculdade de Ciências Sociais, Pontifícia Universidade Católica, São Paulo, 2001.

SANTOS NETO, José Moraes dos. Visão de jogo: primórdios do futebol no Brasil. São Paulo: Cosac Naify, 2002.

SEABRA, Odette Carvalho de Lima. Urbanização e fragmentação: cotidiano e vida de bairro na metamorfose da cidade em metrópole, a partir das transformações do Bairro do Limão. Tese (Livre-Docência em Geografia) - Faculdade de Filosofia, Letras e Ciências Humanas, Universidade de São Paulo, São Paulo, 2003.

SEBRELLI, Juan José. La era del fútbol. Buenos Aires: Debolsillo, 2005.

SHIRTS, Matthew G. Literatura futebolística: uma periodização. In: MEIHY, José Carlos S. B.; WITTER, José S. (Orgs.). Futebol e cultura: coletânea de estudos. São Paulo: Imprensa Oficial: Arquivo do Estado, 1982.

SIMSON, Olga Rodrigues de M. Carnaval em branco e negro: carnaval popular paulistano (1914-1988). São Paulo: Edusp; Imprensa Oficial do Estado de São Paulo, 2007.

SIQUEIRA, Uassyr de. Clubes recreativos: organização para o lazer. In: AZEVEDO, Elciene et al. (Orgs.). Trabalhadores na cidade: cotidiano e cultura no Rio de Janeiro e em São Paulo, séculos XIX e XX. Campinas: Ed. Unicamp, 2009. p. 271-312.

SILVA, Daniela Alves da. Cultura operária: um estudo de caso do Villa Nova Atlético Clube. Dissertação (Mestrado em História) - Faculdade de História, Universidade Federal de Minas Gerais, Belo Horizonte, 2006.

SOUZA, Denaldo Alchorne de. O Brasil entra em campo! Construções e reconstruções da identidade nacional (1930-1947). São Paulo: Annablume, 2008.

STÉDILE, Miguel Enrique. Da fábrica à várzea: clubes de futebol operário em Porto Alegre. Dissertação (Mestrado em História) - Instituto de Filosofia e Ciências Humanas, Universidade Federal do Rio Grande do Sul, Porto Alegre, 2011.

STREAPCO, João Paulo. "Cego é aquele que só vê a bola": o futebol em São Paulo e a formação das principais equipes paulistanas: S. C. Corinthians Paulista, S. E. Palmeiras e São Paulo F. C. (1894-1942). Dissertação (Mestrado em História) - Faculdade de Filosofia, Letras e Ciências Humanas, Universidade de São Paulo, São Paulo, 2011. 
TOLEDO, Luiz Henrique de. Lógicas no futebol. São Paulo: Hucitec/Fapesp, 2002.

VERDÚ, Vicente. El futbol: mitos, ritos y simbolos. Madrid: Alianza Editorial, 1980.

WISNIK, José Miguel. Veneno remédio: o futebol e o Brasil. São Paulo: Companhia das Letras, 2008. 


\section{ANEXOS}

ANEXO A - Quadro de admissão de novos sócios, 1928-1934

\begin{tabular}{|c|c|c|c|c|c|c|c|}
\hline \multicolumn{8}{|c|}{1928} \\
\hline $\mathbf{N}^{\mathbf{o}}$ & Data & Nome do proposto & Idade & Profissão & $\begin{array}{c}\text { Estado } \\
\text { civil }\end{array}$ & Endereço & Nome do proponente \\
\hline 1 & \multirow{4}{*}{$15 / 10$} & José Paulo Baddini & - & - & - & Rua Lopes de Oliveira, 55 & Raphael Guarinelli \\
\hline 2 & & Paulo Aiezza & - & - & - & Rua Garibaldi, 16 & Saverio Russo \\
\hline 3 & & Victorio Clemente & - & - & - & Sem referência & Saverio Russo \\
\hline 4 & & Domenico Alessandri & - & - & - & Rua Lopes Chaves, 13 & Saverio Russo \\
\hline 5 & \multirow{4}{*}{$22 / 10$} & Reynaldo Zaparini & - & - & - & Rua Carandiru, s/n & Antonio T. de Carvalho \\
\hline 6 & & Gabriel Scott & - & - & - & Rua Garibaldi, 90 & Germano Bindo \\
\hline 7 & & Plinio Marcondes & - & - & - & Rua Arco Verde, 33 & Manoel Costa \\
\hline 8 & & Luis Provença & - & - & - & Alameda Nothmann, 45 & Rodolpho Guimarães \\
\hline 9 & \multirow{7}{*}{$22 / 10$} & Mathias Thomaz & - & - & - & Rua Garibaldi, 43 & Manoel Menzani \\
\hline 10 & & Olyveto Gaspar & - & - & - & Rua Anhanguera, 48 & Narciso Gaspar \\
\hline 11 & & Joaquim Brucoli & - & - & - & $\begin{array}{l}\text { Rua Porto Seguro (Villa } \\
\text { Maria Lima, 7) }\end{array}$ & Jeronymo C. Ferro \\
\hline 12 & & \begin{tabular}{|l|} 
Lourenço Baptista de \\
Almeida \\
\end{tabular} & - & - & - & Rua General Osório, 122 & João Cidro \\
\hline 13 & & Pedro Nery & - & - & - & Alameda Nothmann, 11 & - \\
\hline 14 & & Lario E. & - & - & - & - & - \\
\hline 15 & & Emilio Bertozzi & - & - & - & - & Jayme Gomes \\
\hline 16 & \multirow{7}{*}{$05 / 11$} & Paulo de Lima & - & - & - & Rua Anhanguera, 103 & R. Chiochetti \\
\hline 17 & & Carmo Giácomo & - & - & - & Rua Jaraguá, 23 & Antonio P. Paiva \\
\hline 18 & & Angelo Catapani & - & - & - & Rua Arouca, 46 & Antonio Virgilio \\
\hline 19 & & Fernando Chiochetti & - & - & - & Sem referência & Antonio Vergilio \\
\hline 20 & & João Castanha & - & - & - & Rua Garibaldi, 60 & Miguel Clemente \\
\hline 21 & & João Mourita & - & - & - & Rua Cruzeiro, 04 & Germano Chiochetti \\
\hline 22 & & José Cabral & - & - & - & Rua Barra Funda, 11 & Matheus Sabatini \\
\hline 23 & \multirow{9}{*}{$12 / 11$} & Luiz Bruno & - & - & - & Rua Victorino C. & Francisco Gomes \\
\hline 24 & & Gino L. & - & - & - & Rua Anhanguera, 37 & Frederico Colucci \\
\hline 25 & & Domingues de Morais & - & - & - & Rua Barra Funda, 42 & Bartholomeu Maggi \\
\hline 26 & & João Milani & - & - & - & Rua Brigadeiro Galvão, 35 & Bartholomeu Maggi \\
\hline 27 & & Antonio Lauzani & - & - & - & Rua Idau, 26 & Nicola Martins \\
\hline 28 & & Victorino G. & - & - & - & Avenida do Limão, 52 & Manoel Pacheco \\
\hline 29 & & Francisco Hortega & - & - & - & Rua Jaraguá, 11 & Augusto Bigazi \\
\hline 30 & & Gabrieu da Cunha & - & - & - & Rua Barra Funda, 181 & Antonio Latriani \\
\hline 31 & & Luiz Lacana & - & - & - & Rua Garibaldi, 34 & Augusto Bigazi \\
\hline 32 & \multirow{9}{*}{$29 / 11$} & Armando de Augelis & - & - & - & Rua do Bosque, 68 & Augusto Bigazi \\
\hline 33 & & Antonio Vergilio & - & - & - & Rua Anhanguera, 46 & Miguel Latriani \\
\hline 34 & & Pedro Bertolucci & - & - & - & Rua Barra Funda, 161 & Manoel Costa \\
\hline 35 & & Octavio Batricci & - & - & - & Rua do Bosque, 81 & Antonio Victorino \\
\hline 36 & & José Hypolito & - & - & - & Rua Victorino Carneiro, 67 & João Luzia \\
\hline 37 & & Manoel Gomes & - & - & - & - & Nicolau Martino \\
\hline 38 & & Alvarginio de Souza & - & - & - & Rua Cruzeiro, 18 & Toribio Valle \\
\hline 39 & & João Balthazar & - & - & - & Rua Brigadeiro Galvão, 60 & Antonio Latriani \\
\hline 40 & & Mario N. & - & - & - & - & Nicolau Martino \\
\hline
\end{tabular}




\begin{tabular}{|c|c|c|c|c|c|c|c|}
\hline 41 & & $\begin{array}{l}\text { Mauricio Osvaldo } \\
\text { Guimarães }\end{array}$ & - & - & - & $\begin{array}{l}\text { Rua Conselheiro Brotero, } \\
160\end{array}$ & B. Guimarães \\
\hline 42 & & Anastacio Dias & - & - & - & Rua Maria Antonia, 07 & João Hidro \\
\hline 43 & & João dos Santos & - & - & - & Rua do Bosque & João Hidro \\
\hline 44 & & Roque Lolithi & - & - & - & Rua do Bosque, 49 & Germano Chiochetti \\
\hline 45 & & Emilio Caleta & - & - & - & Rua Barra Funda, 107 & Antonio Vergilio \\
\hline 46 & & José de Alencar Ferreira & - & - & - & - & - \\
\hline 47 & & Henrique $\mathrm{P}$. & - & - & - & - & Hugo $P$. \\
\hline 48 & & Antonio Donadio & - & - & - & Rua Anhanguera, 19 & João Giaconotti \\
\hline 49 & \multirow{6}{*}{$19 / 11$} & João do Amaral & - & - & - & Rua Luzitania, 58 & Antonio Vignola \\
\hline 50 & & Francisco Benetti & - & - & - & Rua Jaragua, 36 & Luiz Provenza \\
\hline 51 & & Octavio Lambarnieri & - & - & - & Rua Anhanguera, 113 & Rosario Maggi \\
\hline 52 & & Cezarino Rosa & - & - & - & Avenida Rude, 136 & Rosario Maggi \\
\hline 53 & & Antonio Labatimi & - & - & - & Rua Bosque, 86 & Matheus Labatimi \\
\hline 54 & & Vicente Albizci & - & - & - & Sem referência & Luiz Provenza \\
\hline 55 & \multirow{21}{*}{$26 / 11$} & Antonio del C. & - & - & - & Rua Lavapés, 12 & João Valério \\
\hline 56 & & Otho Ferfille & - & - & - & Rua Areal, 20 & Duarte Medeiros \\
\hline 57 & & Salvador Mastrangioli & - & - & - & Rua Barra Funda, 203 & Bartholomeu Maggi \\
\hline 58 & & Armando Silva & - & - & - & Rua Antonieta, 07 & Rodolpho Mithencout \\
\hline 59 & & Ruvaldo Cicca & - & - & - & Rua Cruzeiro, 32 & Armando Cicca \\
\hline 60 & & Americo G. & - & - & - & Rua Bosque, 89 & Ezio Marchetti \\
\hline 61 & & Silvio Pecille & - & - & - & Rua dos Italianos, 162 & João L. \\
\hline 62 & & Humberto Mosca & - & - & - & Rua Barra Funda, 140 & João L. \\
\hline 63 & & Afonso Lolitto & - & - & - & Rua do Bosque, 49 & Pio Lanterelli \\
\hline 64 & & Valdemar Pingarilho & - & - & - & $\begin{array}{l}\text { Rua Voluntários da Pátria, } \\
439\end{array}$ & Gottardo Biscuola \\
\hline 65 & & Saverio Baccari & - & - & - & Rua Jaragua, 75 & Luiz Provenza \\
\hline 66 & & Auxilo C. & - & - & - & Rua Juvenal Flores, 96 & Luiz Provenza \\
\hline 67 & & Angelina Guizgani & - & - & - & Rua Bosque, 89 & \multirow{6}{*}{$\begin{array}{l}\text { Marchetti Rodolpho M.; } \\
\text { Antonio Satriani; } \\
\text { Antonio T. de Carvalho } \\
\text { Lambrusco; e } \\
\text { Consolato Vignola }\end{array}$} \\
\hline 68 & & Aurelinda Fernandes & - & - & - & Rua Bosque, 26 & \\
\hline 69 & & Aurelia Latriani & - & - & - & Rua Anhanguera, 09 & \\
\hline 70 & & Elvira Jacintho & - & - & - & Rua Bosque, 103 & \\
\hline 71 & & [?] Roberti & - & - & - & - & \\
\hline 72 & & Maria Viguola & - & - & - & Rua Anhanguera, 60 & \\
\hline 73 & & Maria Liberato & - & - & - & - & Antonio de Carvalho \\
\hline 74 & & Amabile Pieruccini & - & - & - & - & Antonio Vignola \\
\hline 75 & & Nena Tezzi & - & - & - & Rua Luzitania, 80 & Antonio Satriani \\
\hline 76 & \multirow{10}{*}{$03 / 12$} & Natalino Besague & - & - & - & Rua Brigadeiro Galvão & Jayme Gomes \\
\hline 77 & & Nino Otami & - & - & - & Rua Adolpho Gordo, 26 & $\begin{array}{l}\text { Antonio Teixeira de } \\
\text { Carvalho }\end{array}$ \\
\hline 78 & & Angelo Lavicci & - & - & - & Rua Barra de Tibagy, 139 & Goitardo Biscuolo \\
\hline 79 & & Humberto Ristaldi & - & - & - & Rua José Paulino, 202 & Luiz Provenza \\
\hline 80 & & Reynaldo Betticci & - & - & - & Rua General Flores, 61 & Luiz Provença \\
\hline 81 & & João Afonso Gross & - & - & - & Rua José Bonifácio, 14 & Bartho Maggi \\
\hline 82 & & Mario Cervante & - & - & - & Praça Olavo Bilac & Miguel Clemente \\
\hline 83 & & Antonio Victorino II & - & - & - & - & R. Chichetti \\
\hline 84 & & Silvio Languini & - & - & - & Rua Bosque, 86 & Matheus Sabatani \\
\hline 85 & & Paschoal B. & - & - & - & Rua Casa Verde & Rodolpho Mithacaltut \\
\hline
\end{tabular}




\begin{tabular}{|c|c|c|c|c|c|c|c|}
\hline 86 & \multirow[t]{2}{*}{$10 / 12$} & Manoel Palombo & - & - & - & Alameda Glete, 60 & \begin{tabular}{|l} 
Antonio Teixeira de \\
Carvalho
\end{tabular} \\
\hline 87 & & Antonio Natale & - & - & - & Rua Luzitania, 30 & Gottardo Biscuolo \\
\hline 88 & \multirow{6}{*}{$17 / 12$} & Nomi Andreomi & - & - & - & $\begin{array}{l}\text { Rua Francisco de Souza, } \\
16\end{array}$ & Caetano Macberomi \\
\hline 89 & & Raul Lacariotti & - & - & - & Rua Bosque, 143 & Matheus Sabatini \\
\hline 90 & & Nicanor Pinedo Vasques & - & - & - & Rua São Vicente de Paula & Antonio T. de Carvalho \\
\hline 91 & & José Saporitti & - & - & - & Rua Bosque, 143 & Nicola Saporitti \\
\hline 92 & & Bruno Caradicci & - & - & - & Rua Bosque, 84 & Matheus Sabatini \\
\hline 93 & & Mario [?] & - & - & - & - & Bartho Maggi \\
\hline 94 & \multirow{9}{*}{$26 / 12$} & Mario de Souza & - & - & - & Rua Bosque, 60 & João Clemente \\
\hline 95 & & Alberto [?] & - & - & - & Rua Gusmões, 9 & José Patrocinio \\
\hline 96 & & José Nagara & - & - & - & Rua Barracea, 53 & Armando Lima \\
\hline 97 & & Tancredo Rodolpho & - & - & - & Rua Anhaia, 250 & José Couto \\
\hline 98 & & \begin{tabular}{|l|} 
Jacinto Torcado \\
\end{tabular} & - & - & - & Rua Capitão Matarazzo & H. Oliveira \\
\hline 99 & & Italo [?] & - & - & - & Rua Bosque & Antonio Vignola \\
\hline 100 & & Benedicto Lemos da Silva & - & - & - & Rua José Paulino & João dos Santos \\
\hline 101 & & Humberto Santilli & - & - & - & Rua João Pereira, 78 & José Couto \\
\hline 102 & & Joaquim Marcolino & - & - & - & Rua Sérgio Moreira, 22 & - \\
\hline \multicolumn{8}{|c|}{1929} \\
\hline 01 & \multirow{11}{*}{$14 / 01$} & Rodolpho Lima & - & - & - & Rua Cruzeiro, 32 & Armando Lima \\
\hline 02 & & Armando Hermani & - & - & - & Rua Palmeiras, 110 & João Cidro \\
\hline 03 & & Fortunato Resuti & - & - & - & Rua Visconde Taunay & Gottardo Biscuola \\
\hline 04 & & Benedicto Lemos Mello & - & - & - & - & Italo Pamiek \\
\hline 05 & & Moacir Prestes & - & - & - & Rua Antonio Paes, 14 & Italo Pamiek \\
\hline 06 & & José Olympio de Moraes & - & - & - & Rua José Paulino & Italo Pamiek \\
\hline 07 & & Caetano Murari & - & - & - & Rua Jaragua, 93 & J. Caetano Ferro \\
\hline 08 & & Fernando Sapienza & - & - & - & Rua Anhanguera, 29 & Miguel Satriani \\
\hline 09 & & Alberto Biachi & - & - & - & Rua Carcioti & João Cidro \\
\hline 10 & & Eggydio Anderboni & - & - & - & Rua Salta Salta, 10 & Antonio Chieregathi \\
\hline 11 & & A. Monteiro & - & - & - & Rua Salta Salta, 12 & Antonio Chieregathi \\
\hline 12 & \multirow{3}{*}{$21 / 01$} & Francisco de Oliveira & - & - & - & $\begin{array}{l}\text { Rua Brigadeiro Galvão, } \\
130\end{array}$ & Miguel Satriani \\
\hline 13 & & Antonio D. & - & - & - & Rua Jaragua, 130 & Caetano Murari \\
\hline 14 & & Vicente Verzimi & - & - & - & Rua Anhanguera, 5 & Antonio Paiva \\
\hline 15 & \multirow{6}{*}{$28 / 01$} & Manoel da Costa & - & - & - & Rua Salta Salta, 52 & José Fernandes \\
\hline 16 & & Antonio V. & - & - & - & Rua Salta Salta, 24 & Antonio Satriani \\
\hline 17 & & Octacílio Pereira & - & - & - & Rua Baixa, 10 & Bartholomeu Maggi \\
\hline 18 & & Francisco Castelhano & - & - & - & Rua Javahés, 34 & Antonio Satriani \\
\hline 19 & & Amadeu Althiere & - & - & - & Rua Javahés, 16 & Antonio Satriani \\
\hline 20 & & Joaquim seixas & - & - & - & Rua Guaianazes, 170 & Antonio Satriani \\
\hline 21 & \multirow{5}{*}{$26 / 02$} & Arthur Ricco & - & - & - & Sem referência & João Maggi \\
\hline 22 & & Marcilio Luchi & - & - & - & Rua Prates, 47 & Antonio C. de Carvalho \\
\hline 23 & & H. Brandt & - & - & - & $\begin{array}{l}\text { Alameda Barão de } \\
\text { Piracicaba, } 78 \\
\end{array}$ & Antonio C. Carvalho \\
\hline 24 & & Boamergis Guimarães & - & - & - & Sem referência & Claudionor Thofaldi \\
\hline 25 & & Raul Lourenço & - & - & - & Rua Salta Salta, 16A & Anthenor Monteiro \\
\hline
\end{tabular}




\begin{tabular}{|c|c|c|c|c|c|c|c|}
\hline 26 & \multirow{3}{*}{$04 / 03$} & Emilio Mazzela & - & - & - & Rua Cruzeiro, 16 & João M. \\
\hline 27 & & Teciano Bissagua & - & - & - & $\begin{array}{l}\text { Rua Conselheiro Brotero, } \\
44\end{array}$ & Emilio Bertucci \\
\hline 28 & & José Bastos & - & - & - & Rua Salta Salta & Delfim da Silva \\
\hline 29 & \multirow{14}{*}{$11 / 03$} & José Felix Martins & - & - & - & $\begin{array}{l}\text { Rua Largo Coração de } \\
\text { Jesus, } 15\end{array}$ & Rogério Pavani \\
\hline 30 & & Domingues Marcello & - & - & - & $\begin{array}{l}\text { Rua Victorino Carneiro, } \\
129^{\mathrm{a}}\end{array}$ & D. Victorelli \\
\hline 31 & & Placito Coelho & - & - & - & Rua da Varzea, 6 & Manoel Gonçalves \\
\hline 32 & & David Bastos & - & - & - & $\begin{array}{l}\text { Alameda Eduardo Prado, } \\
68\end{array}$ & Eduardo Faria \\
\hline 33 & & Luiz A. Pires & - & - & - & $\begin{array}{l}\text { Alameda Eduardo Prado, } \\
68\end{array}$ & Eduardo Faria \\
\hline 34 & & Boamergis Guimarães & - & - & - & - & Claudionor [?] \\
\hline 35 & & Orestes D. & - & - & - & - & Bartholomeu Maggi \\
\hline 36 & & Antonio Lacava & - & - & - & Rua Garibaldi, 34 & Antonio Satriani \\
\hline 37 & & Roque Deodoro & - & - & - & Praça da Republica, 28 & Antonio Satriani \\
\hline 38 & & José [?] & - & - & - & Rua dos Americanos & Orlando Pontes \\
\hline 39 & & Carlos Corrêa & - & - & - & - & Alfredo Sá \\
\hline 40 & & Benedicto Barbosa & - & - & - & Rua do Corrego, 7 & Orestes D. \\
\hline 41 & & Alfredo Bertoloci & - & - & - & Rua Anhanguera, 7 & João Cidro \\
\hline 42 & & Jiovani Francisco & - & - & - & Alameda Nothman & Alfredo Bertolocci \\
\hline 43 & \multirow{4}{*}{$18 / 03$} & Rafael Lourenço & - & - & - & Rua Bosque, 102 & João Cidro \\
\hline 44 & & Carmo Pietoso & - & - & - & Rua Anhanguera, 39 & Fernando Costa \\
\hline 45 & & Alvaro Costa & - & - & - & Rua Anhanguera, $60^{\mathrm{a}}$ & José de Agostinho \\
\hline 46 & & Silvio da Conceição & - & - & - & Rua Gomes Cardim, 164 & João A. Gross \\
\hline 47 & \multirow{2}{*}{$25 / 03$} & Antonio Carlucci & - & - & - & Rua Bosque, 19 & Fortunato R. \\
\hline 48 & & Miguel Daurêa & - & - & - & Rua Garibaldi, 4 & Saverio Russo \\
\hline 49 & $01 / 04$ & Antonio d Abril & - & - & - & Rua Barão de Tatuy, 154 & Miguel Branca \\
\hline 50 & $08 / 04$ & Domingues Bras & - & - & - & - & Antonio Vignola \\
\hline 51 & \multirow{7}{*}{$15 / 04$} & José Manoel & - & - & - & - & João Bello \\
\hline 52 & & Januário Pascoalucci & - & - & - & Rua Manoel Dutra, 83 & Carlos Virgilo \\
\hline 53 & & Eloy Treviziaki & - & - & - & Rua Barra Tibagi, 146 & Fortunato R. \\
\hline 54 & & Amadeu B. & - & - & - & $\begin{array}{l}\text { Rua Conselheiro Nebias, } \\
115\end{array}$ & João A. Giovani \\
\hline 55 & & Bertholdo V. & - & - & - & Rua Xavier de Toledo, 60 & João A. \\
\hline 56 & & João Bello & - & - & - & - & Orlando Pontes \\
\hline 57 & & Renato Limões & - & - & - & Rua Bosque, 75 & Manoel M. \\
\hline 58 & \multirow{5}{*}{$25 / 04$} & Santino Manoel Soares & - & - & - & Rua Duque de Caxias. 39 & João A. Gross \\
\hline 59 & & João Seaglia & - & - & - & Rua Siva Pinto, 13 & João A. Gross \\
\hline 60 & & Antonio Orelo & - & - & - & Rua 13 de Maio, 26 & Amadeu Bianchi \\
\hline 61 & & Manoel Souza & - & - & - & Estrada da Limão, 13 & Carlos Virgilo \\
\hline 62 & & Antonio Riorni & - & - & - & Rua Boracéa, 49 & Antonio Althieri \\
\hline 63 & \multirow{2}{*}{$07 / 05$} & Sivio Lima & - & - & - & Rua Anhanguera, 28 & Ezio Marchetti \\
\hline 64 & & Osvaldo Bicudo & - & - & - & Rua Garibaldi, 2 & O. Monteiro \\
\hline 65 & \multirow{3}{*}{$14 / 05$} & João Russo & - & - & - & Rua do Bosque, 56 & João Paris \\
\hline 66 & & João N. & - & - & - & Rua Barra Funda, 113 & Miguel Viguola \\
\hline 67 & & Francisco Tezzi & - & - & - & Rua Luzitania & Antonio Althiere \\
\hline
\end{tabular}




\begin{tabular}{|c|c|c|c|c|c|c|c|}
\hline 68 & \multirow{8}{*}{$04 / 06$} & Angelo Barbarulo & - & - & - & Rua Ribeiro da Silva, 59 & Joaquim Seixas \\
\hline 69 & & Libertário Court & - & - & - & $\begin{array}{l}\text { Alameda Barão de } \\
\text { Limeira, } 203\end{array}$ & Joaquim Seixas \\
\hline 70 & & Antonio C. & - & - & - & Rua Silva Pinto, 3 & Amadeu Biau \\
\hline 71 & & Caetano Gross & - & - & - & Av. Rudge, 74 & Miguel Branco \\
\hline 72 & & Francisco Viscardi & - & - & - & Rua Javares, 13 & Amadeu Althiere \\
\hline 73 & & Antonio Soares & - & - & - & Rua Salto Salto, 48 & Arsenio Gentil \\
\hline 74 & & Salvador Arquiar & - & - & - & Rua Joaquim, 88 & Jayme Gomes \\
\hline 75 & & Miguel Paris & - & - & - & Rua do Bosque & Miguel Satriano \\
\hline 76 & \multirow{3}{*}{$11 / 06$} & Ricardo Piccardi & - & - & - & Rua General Flores, 131 & Miguel Satriano \\
\hline 77 & & Bernardino Terra & - & - & - & Rua Mamaré, 48 & Miguel de Lima \\
\hline 78 & & Virgilio Lasarini & - & - & - & Rua Anhaia, 164 & Cezar Rosa \\
\hline 79 & \multirow{3}{*}{$18 / 06$} & Osvaldo Negrão & - & - & - & Rua Arthur Azevedo, 25 & José Guimarães \\
\hline 80 & & B.Pelicciani & - & - & - & Rua General Flores, 70 & Fortunato Ressutti \\
\hline 81 & & Luiz d’Elia & - & - & - & Rua Pedro Vicente, 33 & Anthenor Monteiro \\
\hline 82 & \multirow{3}{*}{$02 / 07$} & Donato Cassiano & - & - & - & Rua Anhaia, 157 & Bartholomeu Maggi \\
\hline 83 & & Waldemar de Barros & - & - & - & Rua Alvaro Fontes, 49 & Santino Manoel Soares \\
\hline 84 & & Humberto dell'Acqua & - & - & - & Rua Salta Salta, 8 & Antonio T. de Carvalho \\
\hline 85 & \multirow{5}{*}{$09 / 07$} & Luiz Beniath & - & - & - & $\begin{array}{l}\text { Rua Brigadeiro Galvão, } \\
103\end{array}$ & Antonio T. de Carvalho \\
\hline 86 & & Osvaldo Donatelli & - & - & - & Rua Helvetia, 120 & Antonio T. de Carvalho \\
\hline 87 & & Oscar Costa & - & - & - & Rua Cons. Nebias, 151 & Joaquim Seixas \\
\hline 88 & & João Dias & - & - & - & Rua Cruzeiro, 29b & Miguel Vignola \\
\hline 89 & & Miguel Antunucci & - & - & - & Rua Augusta & Amadeu Biondi \\
\hline 90 & \multirow{3}{*}{$15 / 07$} & $\begin{array}{l}\text { Horacio Pinheiro dos } \\
\text { Santos }\end{array}$ & - & - & - & Rua Cons. Nebias, 146 & Antenor Monteiro \\
\hline 91 & & Roque Ricardo & - & - & - & Largo Coração de Jesus, 11 & Antenor Monteiro \\
\hline 92 & & Ramiro D’Agostinho & - & - & - & Rua Salon, 59 & Bartholomeu Maggi \\
\hline 93 & \multirow{5}{*}{$12 / 08$} & Cassiano & - & - & - & Rua Anhaia, 157 & Cesar Rosa \\
\hline 94 & & Bernardino Barone & - & - & - & Rua do Bosque, 162 & Jeronymo C. Ferro \\
\hline 95 & & Narciso S. Villan & - & - & - & Rua Cons. Brotero, 41 & Antonio T. de Carvalho \\
\hline 96 & & Joaquim Rocha & - & - & - & Rua Cons. Brotero, 41 & Antonio T. de Carvalho \\
\hline 97 & & Alcides Ometto & - & - & - & $\begin{array}{l}\text { Rua Visconde de Taunay, } \\
18\end{array}$ & Manoel de Souza \\
\hline 98 & \multirow{6}{*}{$26 / 08$} & Osvaldo Medeiros & - & - & - & Rua Salta Salta, 38 & Miguel Satriano \\
\hline 99 & & $\begin{array}{l}\text { Joaquim Candora de } \\
\text { Oliveira } \\
\end{array}$ & - & - & - & Rua Souza Lima, 66 & Joaquim Seixas \\
\hline 100 & & Mario Paulino & - & - & - & Rua Barra Tibagy, 18 & - \\
\hline 101 & & José de Abreu & - & - & - & Rua Cruzeiro, 9 & Miguel Branco \\
\hline 102 & & \begin{tabular}{|l|} 
Antonio Correa \\
\end{tabular} & - & - & - & Rua Lopes Chaves [?] & Delphim Silva \\
\hline 103 & & Luiz Grecco & - & - & - & Rua Cesario Motta, 18 & - \\
\hline 104 & \multirow{6}{*}{$02 / 09$} & Paschoal Petrone & - & - & - & - & Benedicto Barbosa \\
\hline 105 & & José Liberato & - & - & - & $\begin{array}{l}\text { Rua Victorino Carmillo, } \\
112\end{array}$ & Antonio Latriano \\
\hline 106 & & Ricardo Sanchos & - & - & - & Rua da Várzea, 2 & Manoel Gonsalves \\
\hline 107 & & Marcello [?] & - & - & - & Rua Eliza Hitaquer, 99 & José Valle \\
\hline 108 & & Osvaldo Bergamini & - & - & - & Rua do Bosque, 54 & Miguel Latriano \\
\hline 109 & & Antonio Menecucci & - & - & - & Rua Anhanguera, 64 & Bartholomeu Maggi \\
\hline 110 & \multirow{2}{*}{$05 / 09$} & João Sanches & - & - & - & Rua Julio Ribeiro, 14 & Osvaldo Bergamini \\
\hline 111 & & Faustino André & - & - & - & Rua Sérgio Meira, 29 & Antonio Latriano \\
\hline
\end{tabular}




\begin{tabular}{|c|c|c|c|c|c|c|c|}
\hline 112 & \multirow{3}{*}{$16 / 09$} & João Sala & - & - & - & Rua Anhanguera, 77 & Victor Barbosa \\
\hline 113 & & Cesar Belloni & - & - & - & Rua Souza Lima, 40 & Antonio T. de Carvalho \\
\hline 114 & & Claudio Ferreira Lima & - & - & - & Rua Alfredo Byol, 182 & Antonio Vignola \\
\hline 115 & \multirow{5}{*}{ 23/09 } & Valerio Belloni & - & - & - & Rua Souza Lima, 46 & Delphim da Silva \\
\hline 116 & & Francisco Tylo & - & - & - & Rua Santo Antonio, 233 & Luiz Grecco \\
\hline 117 & & Caetano Clarice & - & - & - & Rua Souza Lima, 27 & Antonio T. de Carvalho \\
\hline 118 & & Julio Polleto & - & - & - & Villa Pompeia & Cesar Rosa \\
\hline 119 & & Jacintho Tavares & - & - & - & $\begin{array}{l}\text { Rua Ministro Ferreira } \\
\text { Alves, } 46\end{array}$ & Fernando Costa \\
\hline 120 & \multirow{5}{*}{$30 / 09$} & Paulino de Angelis & - & - & - & Av. Rudge, 67 & Bartholomeu Maggi \\
\hline 121 & & $\begin{array}{l}\text { Alfredo de Almeida } \\
\text { Sant'Anna }\end{array}$ & - & - & - & Rua Solon, 55 & José Jacintho \\
\hline 122 & & \begin{tabular}{|l|} 
Nicanor Couto \\
\end{tabular} & - & - & - & Rua Visconde de Taunay, 8 & José Jacintho \\
\hline 123 & & Antonio Miguel & - & - & - & Alameda Eduardo Prado, 35 & João Abreu \\
\hline 124 & & Luiz Medeiros & - & - & - & Rua Inhauma, 22 & João Abreu \\
\hline 125 & \multirow{3}{*}{$09 / 10$} & Reynaldo Côrrea & - & - & - & Rua Lavadia, 5 & Miguel Clemente \\
\hline 126 & & Francisco Ferreira & - & - & - & Rua Luzitania, 62 & José Victorino \\
\hline 127 & & José Leopoldi & - & - & - & Rua Araujo, 47 & Luiz Pereira da Silva \\
\hline 128 & \multirow{2}{*}{$14 / 10$} & Antonio Roga & - & marceneiro & - & Rua Anhanguera, 11 & Antonio Patriano \\
\hline 129 & & Salvador Pepe & - & - & - & Rua General Flores & Germano Bina \\
\hline 130 & \multirow{5}{*}{$22 / 10$} & Miguel M. & - & - & - & Rua Cruzeiro, 50 & Delfim da Silva \\
\hline 131 & & José Vieira & - & - & - & Rua Biguá, 46 & Uberto Oliveira \\
\hline 132 & & Gabriel Medeiros & - & - & - & Rua do Bosque, 95 & João Hidro \\
\hline 133 & & Pedro Benetti & - & - & - & Rua João Rudge, 1 & Jeronymo Carvalho \\
\hline 134 & & Lizieri Grecco & - & - & - & Rua Tupy & João Hidro \\
\hline 135 & \multirow{3}{*}{$04 / 11$} & Rodolpho M. Oliveira & - & - & - & - & Nicanor Costa \\
\hline 136 & & Arthur Sicchieri & - & - & - & - & João Paris \\
\hline 137 & & Guilerme Nicolleti & - & - & - & - & João Paris \\
\hline 138 & \multirow{3}{*}{$11 / 11$} & Italo Romano & - & comerciante & - & \begin{tabular}{|l|} 
Rua C. Moreira Barros, \\
145 \\
\end{tabular} & Osvaldo Bergamini \\
\hline 139 & & José Rodrigues & - & ferroviário & - & $\begin{array}{l}\text { Rua Dr. Amorin de } \\
\text { Azevedo, } 4\end{array}$ & Manoel Gonçalves \\
\hline 140 & & Januario Carbonaro & - & mecânico & - & Rua Borácea, 29 & Carlos Horacio \\
\hline 141 & \multirow{4}{*}{$18 / 11$} & Manoel de Medeiros & - & operário & - & Av. Rudge & Bartholomeu Maggi \\
\hline 142 & & Francisco de Mauro & - & fotógrafo & - & Rua Badaró, 22 & Cesar Rosa \\
\hline 143 & & Nelson Camargo penteado & - & - & - & Rua Seminário, 8 & Cesar Rosa \\
\hline 144 & & Silvio Berto & - & fotógrafo & - & Rua Seminário, 8 & Cesar Rosa \\
\hline 145 & \multirow{6}{*}{$02 / 11$} & João Gomes & - & plainista & - & Rua Solon, 26 & Nicola Martins \\
\hline 146 & & \begin{tabular}{|l|} 
Roberto Paccini \\
\end{tabular} & - & gráfico & - & Rua Solon, 52 & Nicola Martins \\
\hline 147 & & Augusto Pereira & - & gráfico & - & Rua Amaral Gurgel, 40 & João Pavani \\
\hline 148 & & Emilio Tucci & - & encanador & - & Rua Italianos, 185 & Saveiro Russo \\
\hline 149 & & Quirino Farisco & - & cocheiro & - & Casa Verde & Hugo Dioraguini \\
\hline 150 & & Augusto Rodriguez & - & pedreiro & - & Rua Anhanguera, 68 & Miguel Pecile \\
\hline 151 & \multirow{6}{*}{$12 / 12$} & Renato Lara Brisola & - & - & - & Rua Triunpho, 32 & Eduardo Lousada \\
\hline 152 & & Antonio Biassi & - & - & - & Rua do Bosque & Delphin da Silva \\
\hline 153 & & Orlando Landi & - & - & - & Praça Princesa Izabel, 26 & Eduardo Losso \\
\hline 154 & & Benedicto Oliveira & - & - & - & Rua Boracéa, 38 & Miguel Parese \\
\hline 155 & & Manoel Serveja Martino & - & - & - & Rua Barra Tibagy, 112 & Miguel Parese \\
\hline 156 & & José Alves Moreira & - & - & - & Villa Mazzei & Miguel Parese \\
\hline
\end{tabular}




\begin{tabular}{|c|c|c|c|c|c|c|c|}
\hline 157 & & José Martins & - & - & - & Rua do Bosque & Miguel Parese \\
\hline 158 & & José Medeiros & - & - & - & Rua da Baixa, 29 & Jayme Gomes \\
\hline 159 & & Antonio Baptista & - & - & - & Rua Anhanguera, 8 & João Gianotti \\
\hline 160 & \multirow{3}{*}{$16 / 12$} & Andre Palormio & - & - & - & Rua Anhanguera, 111 & Bartholomeu Maggi \\
\hline 161 & & Joaquim C. Junior & - & - & - & Rua Cruzeiro, 87 & Matheus Sabatini \\
\hline 162 & & Orlando Picelli & - & - & - & Rua General Flores & Delphim da Silva \\
\hline 163 & \multirow{4}{*}{$30 / 12$} & Americo Stigliano & - & - & - & Rua do Bosque, 19 & Antonio Patriano \\
\hline 164 & & José Soares & - & - & - & Rua Solimões, 11 & Manoel de Souza \\
\hline 165 & & José Marques & - & - & - & Rua Triumpho, 32 & Antonio Rosa \\
\hline 166 & & José Louzada & - & - & - & Rua Triumpho, 36 & Antonio Rosa \\
\hline \multicolumn{8}{|c|}{1930} \\
\hline 1 & \multirow{2}{*}{ 06/01 } & Americo Montes & - & mobileiro & - & Rua Tibagy, 8 & Miguel Parese \\
\hline 2 & & Humberto Perrão & - & mecânico & - & Rua Solon, 153 & Miguel Parese \\
\hline 3 & \multirow{3}{*}{$13 / 01$} & Bachin Balliani & - & comércio & - & Rua Santo André, 49 & Miguel Parese \\
\hline 4 & & Eduardo Jorge & - & estudante & - & Rua Santo André, 21 & Miguel Parese \\
\hline 5 & & Carmino Vitelli & - & - & - & Rua Tocantins, 8 & Saverio Russo \\
\hline 6 & \multirow{3}{*}{$20 / 01$} & Guilherme Berthi & - & marceneiro & - & Rua Barra do Tibagy, 24 & Antonio Dermisso \\
\hline 7 & & Raphael Jhaen & - & - & - & Rua Salomões, 1 & Manoel Costa \\
\hline 8 & & Victor Francisco & - & - & - & \begin{tabular}{|l} 
Rua Voluntários da Pátria, \\
10
\end{tabular} & Jeronymo Caetano \\
\hline 9 & \multirow{2}{*}{ 28/01 } & Francisco Rufini & - & - & - & Rua Mendes Junior, 43 & Saverio Russo \\
\hline 10 & & Alvaro Pollo & - & - & - & Rua Anhanguera, 25 & Arsenio Gentil \\
\hline 11 & \multirow{2}{*}{$03 / 02$} & Eduardo dos Santos & - & - & - & Rua Costa Silva, 118 & João Bello \\
\hline 12 & & Raphael Sapienza & - & comércio & - & Rua do Bosque & Jeronymo Caetano \\
\hline 13 & \multirow{6}{*}{$06 / 02$} & Atione Zernardi & - & & - & - & João Morgato \\
\hline 14 & & Henrique Aguiar & - & - & - & - & - \\
\hline 15 & & Antonio Bergamini & - & - & - & - & Miguel Satriano \\
\hline 16 & & Victorio Pardini & - & - & - & - & Miguel Vignola \\
\hline 17 & & Americo De Angelis & - & - & - & - & Miguel Vignola \\
\hline 18 & & Antonio Althiere & - & - & - & - & Paulo de Lima \\
\hline 19 & \multirow{5}{*}{$10 / 02$} & Bruno de Polli & - & ladrilheiro & - & Rua Baracea, 53 & Miguel Pesili \\
\hline 20 & & Raul Medeiros & - & - & - & Rua Anhanguera & Manoel Costa \\
\hline 21 & & Domingos Lemonte & - & - & - & - & Reynaldo Lima \\
\hline 22 & & Alfredo P. da Silva & - & - & - & - & Antonio Vignola \\
\hline 23 & & Gumercindo Martins & - & - & - & - & Antonio Vignola \\
\hline 24 & \multirow{3}{*}{$17 / 02$} & Donato Boni & - & comércio & - & Rua Pedro Thomaz, 5 & Germano Bindo \\
\hline 25 & & \begin{tabular}{|l|} 
João Toscano \\
\end{tabular} & - & chapeleiro & - & Rua da Graça, 205 & Nicola Martins \\
\hline 26 & & Heitor Paiva & - & soldador & - & - & Antonio Victorino \\
\hline 27 & \multirow{2}{*}{$24 / 02$} & Daniel de Almeida & - & - & - & Rua Anhanguera, 14 & Severino Russo \\
\hline 28 & & João Bonato & - & - & - & Rua do Bosque, 81 & Manoel Costa \\
\hline 29 & \multirow{7}{*}{$10 / 03$} & Luiz de Mattos & - & - & - & Rua Veridiana, 48 & Oscar Costa \\
\hline 30 & & Fernando P. Guimarães & - & escrevente & - & Rua Conselheiro Brotero,103 & José P. Guimarães \\
\hline 31 & & Eugenio Mazella & - & pintor & - & Rua Cruzeiro, 16 & Jayme Gomes \\
\hline 32 & & Mario Martins & - & mecânico & - & Rua dos Italianos, 219 & Antonio Vignola \\
\hline 33 & & Julio Boni & - & & - & Rua Pedro Thomaz, 5 & Renato Boni \\
\hline 34 & & Hygino Ferrazalli & - & gráfico & - & Rua Souza Lima, 48 & Bartholomeu Maggi \\
\hline 35 & & Waldemar Costa & - & mecânico & - & Rua Estação Sorocabana & José Soares \\
\hline
\end{tabular}




\begin{tabular}{|c|c|c|c|c|c|c|c|}
\hline 36 & & Luiz Natalli & - & comércio & - & Rua Jorge Velho, 3 & Luiz Greco \\
\hline 37 & & João Chinaglio & - & comércio & - & Rua Anhaia, 191 & Saverio Russo \\
\hline 38 & & Antonio Castro & - & - & - & Rua Cristina Thomaz, 141 & Jeronymo Caetano \\
\hline 39 & & José Coelho & - & - & - & $\begin{array}{l}\text { Rua Cardoso de Almeida, } \\
71\end{array}$ & Jeronymo Caetano \\
\hline 40 & & Luiz E. G[?] & - & - & - & Rua Cruzeiro, 10 & Miguel Parese \\
\hline 41 & & Sebastião F. de [?] & - & - & - & Rua do Corrego, 5 & Miguel Parese \\
\hline 42 & \multirow{2}{*}{$17 / 03$} & Francisco Dias & - & negociante & - & Rua Barra Funda, 73 & Miguel Vignola \\
\hline 43 & & Moacyr Mazzali & - & lustrador & - & Rua do Bosque, 21 & Bartholomeu Maggi \\
\hline 44 & \multirow{3}{*}{$24 / 03$} & Francisco Cassino & - & comércio & - & Rua dos Italianos, 223 & Antonio Vignola \\
\hline 45 & & João Silva Xavier & - & - & - & Rua Albuquerque Luiz, 51 & JoãoCidro \\
\hline 46 & & $\begin{array}{l}\text { Antonio Bartholomeu } \\
\text { Greco }\end{array}$ & - & - & - & Rua Albuquerque Luiz, 51 & João Cidro \\
\hline 47 & \multirow{4}{*}{$31 / 03$} & Armando D’Amelio & - & comércio & - & Al. Barão de limeira & Luiz Provenza \\
\hline 48 & & José Montero & - & - & - & Rua Salta Salta, 14 & Antemor Monteiro \\
\hline 49 & & João Belli & - & - & - & Rua Boracea, 9 & Antemor Monteiro \\
\hline 50 & & Manoel Soares Cavalheiro & - & - & - & - & Manoel de Souza \\
\hline 51 & \multirow{5}{*}{$07 / 04$} & Raphael F[?] & - & - & - & Rua Aymorés, 35 & Jayme Gomes \\
\hline 52 & & Vicente D. Giamini & - & - & - & Rua Aymorés, 50 & Jayme Gomes \\
\hline 53 & & Antonio Calvo & - & - & - & Rua Cruzeiro, 44 & Manoel de Souza \\
\hline 54 & & Vicente Lemonte & - & - & - & Rua Cruzeiro, 35 & Domingos Lemonte \\
\hline 55 & & Roberto Tavares & - & - & - & Rua Cruzeiro, 17 & Luiz Grecco \\
\hline 56 & \multirow{2}{*}{$14 / 04$} & Orestes Dalceno & - & - & - & - & Bartholomeu Maggi \\
\hline 57 & & Silvio Vignola & - & - & - & - & Saverio Russo \\
\hline 58 & $22 / 04$ & Americo Tessaroli & - & - & - & Rua do Corrego & Armando Lima \\
\hline 59 & \multirow{4}{*}{$28 / 04$} & Januario Carbonato & - & - & - & Rua Boracéa, 29 & Saveiro Russo \\
\hline 60 & & Henrique Ferreira Costa & - & - & - & Rua Anhaia, 177 & Saverio Russo \\
\hline 61 & & Antonio Corrêa & - & - & - & Rua Barra de Tibagy, 140 & Antonio T. Carvalho \\
\hline 62 & & Benedicto Julio Felizola & - & - & - & $\begin{array}{l}\text { Rua Travessa Tenente } \\
\text { Penna, } 11\end{array}$ & Antonio T. Carvalho \\
\hline 63 & \multirow{5}{*}{$05 / 05$} & Alberto de Oliveira & - & ferroviário & - & Rua Anhaia, 142 & Antonio T. Carvalho \\
\hline 64 & & João Chiachetti & - & gráfico & - & Rua C. de Almeida, 19 & Antonio T. Carvalho \\
\hline 65 & & Jorge Pedro & - & - & - & Rua Tibiriça & Saverio Russo \\
\hline 66 & & Angelo Bergamaschi & - & - & - & Rua da Várzea, 16 & Ricardo Lauce \\
\hline 67 & & Francisco Gomes & - & - & - & Rua do Bosque & Saveiro Russo \\
\hline 68 & \multirow{3}{*}{$22 / 05$} & Antonio Lopes & - & - & - & Rua Cruzeiro, 95 & Bartholomeu Maggi \\
\hline 69 & & Otto Mittel & - & - & - & Rua Anhanguera, 87 & Antonio Vignola \\
\hline 70 & & [?] Pareschi & - & - & - & Rua Camaragibe, 9 & Antonio del Aqua \\
\hline 71 & \multirow{2}{*}{$26 / 05$} & Onofre Penteado & - & comércio & - & Rua São Caetano, 216 & Antonio Vignola \\
\hline 72 & & Lambardini Fontana & - & comércio & - & Rua General Osório, 106 & Antonio Vignola \\
\hline 73 & \multirow{4}{*}{$02 / 06$} & José Talarico & - & - & - & $\begin{array}{l}\text { Rua Cardoso de Almeida, } \\
28\end{array}$ & Vicente [?] \\
\hline 74 & & José Mourato Castanha & - & - & - & Al. Barão de Limeira, 28 & Jeronymo Caetano \\
\hline 75 & & Manoel Milleu & - & - & - & Rua Baixa, 17 & Miguel Vignola \\
\hline 76 & & Patrus Fornaciari & - & - & - & Rua Salta Salta, 13 & Bartholomeu Maggi \\
\hline 77 & \multirow{4}{*}{ 09/06 } & Duarte de Mattos & - & - & - & Rua do Bosque, 208 & Manoel de Souza \\
\hline 78 & & Manoel Ignacio de Souza & - & - & - & Rua Cruzeiro, 19 & José Ignácio de Souza \\
\hline 79 & & Adriano Baldresca & - & - & - & Rua do Bosque, 232 & Jeronymo C. Ferro \\
\hline 80 & & Domingos Farolaro & - & - & - & Rua Casa Verde, 87 & Saverio Russo \\
\hline
\end{tabular}




\begin{tabular}{|c|c|c|c|c|c|c|c|}
\hline 81 & & Francisco Lojaro & - & - & - & Rua Anhanguera, 138 & João Morgato \\
\hline 82 & & [?] Chiachetti & - & - & - & Rua Turiassu, 61 & Saverio Russo \\
\hline 83 & $07 / 07$ & Listo Botini & - & - & - & Av. Rudge, 66 & Reynaldo Botini \\
\hline 84 & \multirow{4}{*}{$14 / 07$} & Romeu Quinaglia & - & - & - & Rua Anhaia, 191 & José Monterio \\
\hline 85 & & Matheus Del Pozzo & - & - & - & Rua Anhaia, 245 & José Monteiro \\
\hline 86 & & Antonio Azevedo & - & - & - & Rua Anhanguera, 87 & Fernando Costa \\
\hline 87 & & Arualdo & - & - & - & Rua da Graça & João Morgato \\
\hline 88 & \multirow{5}{*}{$21 / 07$} & Anthamir Dias & - & - & - & Rua do Bosque, 42 & João Maggi \\
\hline 89 & & Armando Pitillo & - & - & - & $\begin{array}{l}\text { Rua Conselheiro Brotero, } \\
160\end{array}$ & G. Carbono \\
\hline 90 & & Florindo V[?] & - & - & - & Rua Garibaldi, 56 & Gino Pistorezi \\
\hline 91 & & Daniel Almeida & - & - & - & Rua Asdrúbal, Nascimento & Villa Marchetti \\
\hline 92 & & Antonio Oliveira & - & - & - & Rua Cruzeiro, 19 & R. Quinaglia \\
\hline 99 & \multirow{3}{*}{$28 / 07$} & José Piacerre & - & - & - & Rua Boracea, 49 & Antonio Altieri \\
\hline 100 & & Jorge dos Santos & - & - & - & Rua Casa Verde, 15 & Manuel Costa \\
\hline 101 & & [?] Bellani & - & - & - & Rua Souza Lima & Egydio Luiz \\
\hline 102 & \multirow{5}{*}{$04 / 08$} & Mario Vieira & - & - & - & Rua dos Italianos, 44 & Vicente Lemonte \\
\hline 103 & & Emilio Tucci & - & - & - & Rua dos Italianos, 185 & Antenor Monteiro \\
\hline 104 & & Jorge Roatta & - & - & - & Rua Garibaldi, 18 & Miguel Parisi \\
\hline 105 & & Gino [?] & - & - & - & Rua das Palmeiras, 33 & Seraphim Santarelli \\
\hline 106 & & Oswaldo Benvenuto & - & - & - & Rua Carnot, 15 & Seraphim Santarelli \\
\hline 107 & \multirow{3}{*}{$11 / 08$} & Luiz Molanque & - & - & - & - & Jayme Gomes \\
\hline 108 & & Larentino Alves & - & - & - & Rua Barra do Tibagy, 124 & José Alves \\
\hline 109 & & José Alves & - & - & - & Rua General Osorio, 6 & Luiz Provença \\
\hline 110 & $25 / 08$ & Augusto Casalli & - & - & - & Rua do Bosque, 84 & José Valle \\
\hline 111 & \multirow{2}{*}{$01 / 09$} & Horacio [?] & - & - & - & Rua do Bosque, 19 & Manoel Menzani \\
\hline 112 & & Antonio Marques & - & - & - & Rua Casa Verde & Domingos Lemonte \\
\hline 113 & \multirow{4}{*}{$15 / 09$} & Armando Perucini & - & - & - & Rua Boracea, 5 & Horacio Stigliani \\
\hline 114 & & Antonio Favero & - & - & - & Rua Garibaldi, 43 & Secretaria \\
\hline 115 & & Salvador M. Passos & - & - & - & Rua Lopes de Oliveira, 14 & Manoel Costa \\
\hline 116 & & Manoel Limões da Silva & - & - & - & Rua Marquez de Itu, 48 & Secretaria \\
\hline 117 & \multirow{5}{*}{$23 / 09$} & Orlando Novello & - & - & - & Rua Barra Funda, 191 & João Morgato \\
\hline 118 & & Arthur Lopes de Almeida & - & - & - & Rua Anhanguera, 13 & Manoel Simões \\
\hline 119 & & Miguel Simões Ferreira & - & - & - & Rua Luzitania, 68 & Manoel Simões Silva \\
\hline 120 & & Manoel de Mello & - & - & - & Av. Rudge, 167 & José Ignácio de Souza \\
\hline 121 & & Francisco Francescucci & - & - & - & Rua das Palmeiras, $75^{\mathrm{a}}$ & Miguel Vignola \\
\hline 122 & $21 / 10$ & Nicola Saporito & - & - & - & Rua do Bosque, & Antonio Favero \\
\hline 123 & \multirow{2}{*}{$19 / 11$} & Duarte Medeiros & - & - & - & Rua Anhanguera, 137 & Matheu Sabatini \\
\hline 124 & & Pedro Benette & - & - & - & Rua Solimões, 14 & Arthur Lopes de Almeida \\
\hline \multicolumn{8}{|c|}{1931} \\
\hline 1 & \multirow{6}{*}{$05 / 01$} & Camillo dos Santos & 23 & pintor & - & Rua Inhaúma & Antônio T. Carvalho \\
\hline 2 & & João Gomes & 24 & marceneiro & - & Rua Inhaúma & Antônio T. Carvalho \\
\hline 3 & & Eduardo dos Santos & 23 & - & - & Rua Inhaúma & Antônio T. Carvalho \\
\hline 4 & & José Cardoni & 18 & açougueiro & - & Rua Piahy & Armando A. \\
\hline 5 & & Carlos Medeiros & 18 & comércio & - & Rua Boracéa, 28 & José Monteiro \\
\hline 6 & & Nelson Gamboa & 18 & comércio & - & Rua Salta-Salta, 14 & Carlos Medeiros \\
\hline
\end{tabular}




\begin{tabular}{|c|c|c|c|c|c|c|c|}
\hline 7 & \multirow{3}{*}{$10 / 01$} & Oswaldo Mauro Giglio & 27 & graphico & - & Rua Anhaia, 45 & Antonio Althieri \\
\hline 8 & & Manoel da Silva & 19 & padeiro & - & Rua Anhanguera, 143 & Paulo de Lima \\
\hline 9 & & Sauti Poffo & 43 & barbeiro & - & Rua Anhanguera, 35 & Antonio Vignola \\
\hline 10 & \multirow{9}{*}{$19 / 01$} & Remo Marinelli & 20 & marceneiro & - & Rua Casa Verde, 25 & Antonio T. Carvalho \\
\hline 11 & & Octavio Pareschi & 19 & barbeiro & - & Rua Victorino Camillo, 17 & Antonio T. Carvalho \\
\hline 12 & & Marino Pacheco & 19 & pintor & - & Rua Inhaúma, 15 & Antonio T. Carvalho \\
\hline 13 & & Joaquim dos Santos & 26 & padeiro & - & Rua Baixa, 2 & Miguel S. Ferreira \\
\hline 14 & & José Dias Gomes & 19 & padeiro & - & Rua Baixa, 2 & Miguel S. Ferreira \\
\hline 15 & & Manoel Borges de Lima & 22 & padeiro & - & Rua Anhanguera, 5 & Miguel S. Ferreira \\
\hline 16 & & José de Mazzi & 23 & marceneiro & - & Rua Cruzeiro & Fernando Fuzer \\
\hline 17 & & Rolando Medeiros & 18 & comércio & - & Rua Anhanguera, 137 & Duarte Medeiros \\
\hline 18 & & Elydio S. & 19 & marceneiro & - & Rua Anhanguera, 167 & Duarte Medeiros \\
\hline 19 & \multirow{7}{*}{$26 / 01$} & Arlindo Chicão & 20 & serralheiro & - & Rua Anhaia, 59 & José Menzani \\
\hline 20 & & Geraldo Marasco & 18 & - & - & Rua Cruzeiro & Duarte Medeiros \\
\hline 21 & & \begin{tabular}{|l|} 
Vicente Virgínio \\
\end{tabular} & 20 & - & - & Rua Anhanguera & Ezzio Marchetti \\
\hline 22 & & Waldomiro dos Santos & 18 & - & - & Rua Lucilla, 24 & Oswaldo Medeiros \\
\hline 23 & & Domingos F. & 22 & - & - & Rua Rudge & Paulo de Lima \\
\hline 24 & & Armenio dos Santos & 28 & - & - & Rua Sergio Thomaz & Ezzio Marchetti \\
\hline 25 & & Albino Pereira dos Santos & - & - & - & Rua Albuquerque Lins, 152 & Arthur Lopes de Almeida \\
\hline 26 & \multirow{4}{*}{$02 / 02$} & Negro Guido & - & - & - & Rua do Bosque, 69 & Duarte de Mattos \\
\hline 27 & & Eduardo Cinquini & - & - & - & Rua Anhanguera, 26 & $\begin{array}{l}\text { Fez a proposta diretamente } \\
\text { na secretaria. }\end{array}$ \\
\hline 28 & & Antonio Barone & - & - & - & Rua do Bosque, 162 & Jeronymo Caetano \\
\hline 29 & & Antonio Cirolli & - & - & - & Rua do Bosque & João do Valle \\
\hline 30 & \multirow{3}{*}{$09 / 02$} & Luiz Ramos & 20 & - & - & Rua Pedro Vicente, 60 & Germano Bindo \\
\hline 31 & & Antonio Pires & 22 & - & - & Avenida Cantareira & Germano Bindo \\
\hline 32 & & Ricieri Corsato & 23 & - & - & Rua do Bosque & Jeronymo Caetano \\
\hline 33 & \multirow{4}{*}{$24 / 02$} & David Bastos & 23 & padeiro & - & Rua das Palmeiras, 41 & Eduardo Faria \\
\hline 34 & & Arthur Cardoso de Sá & 27 & padeiro & casado & Rua das Palmeiras, 41 & Eduardo Faria \\
\hline 35 & & Hilário D. Motta & 23 & - & - & Rua das Palmeiras, 41 & $\begin{array}{l}\text { Fez a proposta diretamente } \\
\text { na secretaria. }\end{array}$ \\
\hline 36 & & Joaquim Cardoso & 22 & marceneiro & - & Rua Cruzeiro, 120 & Domingos Lemonte \\
\hline 37 & \multirow{4}{*}{$02 / 03$} & Edson Lacerda & 18 & estudante & - & $\begin{array}{l}\text { Rua Baronesa de Porto } \\
\text { Carreiro, } 1\end{array}$ & $\begin{array}{l}\text { Antonio Teixeira de } \\
\text { Carvalho }\end{array}$ \\
\hline 38 & & Oswaldo Correa & 19 & comércio & - & $\begin{array}{l}\text { Rua Baronesa de Porto } \\
\text { Carreiro, } 8 \\
\end{array}$ & $\begin{array}{l}\text { Antonio Teixeira de } \\
\text { Carvalho }\end{array}$ \\
\hline 39 & & José Seixas & 25 & comércio & - & Pça Marechal Deodoro, 34 & Arthur Lopes de Almeida \\
\hline 40 & & Reinaldo Lima & 22 & entallhador & - & Rua Cruzeiro, 78 & Armando Lima \\
\hline 41 & \multirow{7}{*}{$16 / 03$} & José Soares & 22 & comércio & - & Rua Albuquerque Lins, 152 & Miguel Ferreira \\
\hline 42 & & Graciliano G. & 30 & lustrador & - & Rua Anhanguera, 46 & Ezzio Marchetii \\
\hline 43 & & Joaquim de Jesus & 22 & padeiro & solteiro & Avenida São João, 129b & Arthur Lopes \\
\hline 44 & & Carlos B. S. & 19 & estudante & solteiro & Rua Anhanguera, 4 & João Bellis \\
\hline 45 & & Cesar Rosa & 20 & - & solteiro & Avenida Rudge, 136 & $\begin{array}{l}\text { Antonio Teixeira de } \\
\text { Carvalho }\end{array}$ \\
\hline 46 & & Mario da Silva Reis & 25 & comércio & - & Rua Albuquerque Lins, 152 & José Soares \\
\hline 47 & & Victorio Mendes & 20 & ladrilheiro & - & Rua Martins Buchard, 1 & Miguel Marasco \\
\hline 48 & \multirow{3}{*}{$23 / 03$} & José Cestari & 19 & tipógrafo & solteiro & Rua Souza Lima, 83 & Henrique Clemente \\
\hline 49 & & José V. Galanti & 25 & pedreiro & casado & Rua Anhanguera, 57 & Alfredo Chiochetti \\
\hline 50 & & Antonio Marques & 24 & comerciante & solteiro & Rua Cruzeiro, 121 & Joaquim Cardoso \\
\hline
\end{tabular}




\begin{tabular}{|c|c|c|c|c|c|c|c|}
\hline 51 & & João H. da Costa & 29 & padeiro & solteiro & Alameda Glete, 49 & Miguel S. Ferreira \\
\hline 52 & & Herculano Marques & 22 & comerciante & solteiro & Rua Albuquerque Lins, 152 & Mario Silva Reis \\
\hline 53 & & Pedro Vagiani & 30 & comerciante & solteiro & Rua Lopes de Oliveira, 26 & João Salles \\
\hline 54 & & Antonio Silva dos Santos & 19 & padeiro & solteiro & Rua Anhanguera, 66 & Arthur de Almeida \\
\hline 55 & & José Mendonça & 19 & comerciante & solteiro & Rua Solimões, 12 & R. Minelli \\
\hline 56 & \multirow{4}{*}{$30 / 03$} & Irineu de Moura & 18 & encanador & solteiro & Rua Augusta & Bartholomeu Maggi \\
\hline 57 & & Alberto Ramos & 18 & estudante & solteiro & Rua dos Andradas, 25 & Edson Amazonas \\
\hline 58 & & José Alves da Silva & 28 & padeiro & - & Rua Cruzeiro, 113 & Maximiliano Pires \\
\hline 59 & & Joaquim dos Santos & 42 & carpinteiro & casado & Rua Cruzeiro & Anselmo Gentil \\
\hline 60 & \multirow{3}{*}{$13 / 04$} & Casemiro M. & 27 & mecânico & - & Rua Cruzeiro, 104 & Vicente L. \\
\hline 61 & & Joaquim Coutinho & 22 & padeiro & solteiro & Rua Anhanguera, 13 & Arthur Lopes de Almeida \\
\hline 62 & & Arthur Pereira & 20 & padeiro & solteiro & Rua Solimões, 17 & José Soares \\
\hline 63 & \multirow{3}{*}{$27 / 04$} & Luiz Porreta & - & comerciante & solteiro & Rua Eduardo Chaves & Antonio Biaggio \\
\hline 64 & & Antonio d’Abril & 22 & comércio & solteiro & Avenida Angélica, 90 & Anselmo Gentil \\
\hline 65 & & \begin{tabular}{|l|} 
João d'Abril \\
\end{tabular} & 20 & comércio & solteiro & Avenida Angélica, 90 & Anselmo Gentil \\
\hline 66 & \multirow{4}{*}{$18 / 05$} & Antonio Hirashavitz & 23 & mecânico & solteiro & Rua do Bosque, 25 & - \\
\hline 67 & & Ricardo Forli & 24 & comércio & solteiro & $\begin{array}{l}\text { Rua Capitão Matarazzo, } \\
162 \\
\end{array}$ & Augusto Casalli \\
\hline 68 & & Aldo Capelli & 20 & pintor & solteiro & Rua Casa Verde, 22 & João Faria \\
\hline 69 & & Carlos Fernandes & 20 & fundidor & solteiro & Rua S.[?], 73 & João Faria \\
\hline 70 & \multirow{7}{*}{$26 / 05$} & Henrique Batispta & 22 & padeiro & solteiro & Avenida São João, 190 & Joaquim Jesus \\
\hline 71 & & Antonio Gonçalves & 24 & padeiro & solteiro & $\begin{array}{l}\text { Avenida Marquês de Itu, } \\
52\end{array}$ & Antonio da Silva Santos \\
\hline 72 & & Ettore Sinelli & 21 & chauffer & solteiro & Rua Coronel Cintra, 21 & Casemiro M. \\
\hline 73 & & Leopoldo Coutinho & 22 & comerciante & solteiro & Rua Barra do Tibagy, 72 & Alvaro Pereira \\
\hline 74 & & Constantino $\mathrm{T}$. & 20 & mecânico & solteiro & Rua Coronel Cintra, 27 & - \\
\hline 75 & & Lourenço Fernandes & 25 & padeiro & solteiro & Rua Albuquerque Lins, 152 & M. Souza \\
\hline 76 & & Gilberto Lage & 19 & padeiro & solteiro & $\begin{array}{l}\text { Rua Voluntários da Pátria, } \\
241\end{array}$ & Arthur Lopes de Almeida \\
\hline 77 & 01/06 & Belmiro de Almeida & 26 & comerciante & - & Rua Albuquerque Lins, 152 & José Soares \\
\hline 78 & \multirow{3}{*}{ 08/06 } & Mercantonio & 18 & açougueiro & solteiro & Rua Souza Lima, & João Paris \\
\hline 79 & & Maximiliano Branco & 22 & comércio & - & - & Manoel de Mello \\
\hline 80 & & Alexandre Martins & 21 & mecânico & solteiro & Rua Anhaia, 52 & Ezzio Marchetti \\
\hline 81 & \multirow[t]{2}{*}{$16 / 06$} & Miguel Rasuko & 23 & chauffer & solteiro & $\begin{array}{l}\text { Rua Baronesa do Porto } \\
\text { Carreiro, } 17\end{array}$ & - \\
\hline 82 & & Edewigs Antonio Marques & 21 & comércio & solteiro & - & Aldo Capelli \\
\hline 83 & \multirow{2}{*}{$26 / 06$} & Luiz Taricone & 19 & & solteiro & Rua Julio Conceição, 109 & Octavio Pareschi \\
\hline 84 & & João Ferreira & 24 & impressor & solteiro & Rua Jaraguá, 46 & Ezzio Marchetti \\
\hline 85 & $29 / 06$ & Eduardo de Souza & 22 & comércio & solteiro & - & Antonio Satriano \\
\hline 86 & \multirow{6}{*}{$14 / 07$} & Luiz Gaoperazzi & 18 & comércio & - & Rua do Bosque & Eugenio Mazzalli \\
\hline 87 & & Antonio Cocito & 18 & comércio & - & Rua Cruzeiro, 8 & João Paris \\
\hline 88 & & Henrique Monteiro & 28 & - & - & João Ramalho, 89 & Miguel Ferreira \\
\hline 89 & & Alvaro de Oliveira & 18 & $\begin{array}{l}\text { caramelista } \\
{[?]}\end{array}$ & - & José Paulino, 37 & Oswaldo Correia \\
\hline 90 & & Máximo Ferreira & 28 & padeiro & - & Rua Baixa, 2 & José Dias Gomes \\
\hline 91 & & Victor Clemente & 21 & typographo & - & Rua Anhanguera, 3 & Ezzio Marchetti \\
\hline 92 & \multirow{3}{*}{$27 / 07$} & Aristides Oliveira & 19 & $\begin{array}{l}\text { operador de } \\
\text { cinema }\end{array}$ & - & Rua José Paulino, 37 & Oswaldo Correia \\
\hline 99 & & Octavio Gambarini & 22 & marceneiro & - & Rua Anhanguera, 169 & Moacyr Mazzali \\
\hline 100 & & Domingos C. & 19 & marceneiro & - & Rua Cruzeiro, 160 & Geraldo Marasco \\
\hline
\end{tabular}




\begin{tabular}{|c|c|c|c|c|c|c|c|}
\hline 101 & & Danilo Ferrara & 22 & pintor & - & Rua Baixa, 14 & Horacio Stigliano \\
\hline 102 & & Napoleão Mario & 19 & graphico & - & Rua das Palmeiras, 145 & Octavio Pareschi \\
\hline 103 & & Manoel Pereira & 23 & operário & - & Rua Dr. Elias Chaves, 1 & Jesus Paschoalino \\
\hline 104 & $03 / 08$ & Carlos Colussi & 19 & livreiro & - & Rua Garibaldi, 59 & Antonio Cocito \\
\hline 105 & $10 / 08$ & Francisco Mecca & 21 & $\begin{array}{l}\text { torneiro- } \\
\text { mecânico }\end{array}$ & - & Rua Anhaia, 22 & Oswaldo Bindo \\
\hline 106 & $17 / 08$ & Miguel de Mattos & 19 & operário & - & Rua do Bosque, 114 & João Paris \\
\hline 107 & $24 / 08$ & João Salla & 24 & operário & - & Rua Luzitânia, 43 & Antonio Cocito \\
\hline 108 & $31 / 08$ & Alberto Batispta & 18 & comércio & - & $\begin{array}{l}\text { Alameda Barão do Rio } \\
\text { Branco, } 38\end{array}$ & Manoel Ferreira \\
\hline 109 & \multirow{6}{*}{$14 / 09$} & Antonio de Oliveira & 20 & instalador & - & Rua Anhanguera, 153 & Paulo de Lima \\
\hline 110 & & Antonio Victorino & 19 & chauffer & - & Rua Cruzeiro, 175 & João Paris \\
\hline 111 & & Luiz Rondinelli & 18 & comerciante & - & Rua Casa Verde & Francisco Soterza \\
\hline 112 & & Armando Bindo & 18 & torneiro & - & Rua Maria, 55 & João Paris \\
\hline 113 & & Alfredo Leitão & 24 & - & - & Rua Luzitânia, 68 & Manuel Silva \\
\hline 114 & & João Conselheiro & 21 & mecânico & - & Rua Anhanguera, 149 & Rodolpho Lima \\
\hline 115 & \multirow{5}{*}{$21 / 09$} & Eduardo Faria & 27 & lustrador & - & Rua Oriente, 188 & Ezzio Marchetti \\
\hline 116 & & João dos Santos & 20 & gráfico & - & Rua Casa Verde & Aldo Capelli \\
\hline 117 & & Armando Pierucini & 20 & mecânico & - & Rua Boracea & José Pierucini \\
\hline 118 & & Antonio Chieregatti & 28 & chauffer & - & Rua Salta-Salta, 4 & João Paris \\
\hline 119 & & Antonio Giuliani & 28 & operário & - & Rua Garibaldi, 61 & João Paris \\
\hline 120 & \multirow{3}{*}{$28 / 09$} & Oscar de Andrada & 23 & graphico & - & Rua Salta Salta, 40 & Vittorio Olivieri \\
\hline 121 & & Carlos Cluiusti & 18 & pintor & - & Rua Anhaia, 67 & Alexandre Martini \\
\hline 122 & & Pedro Valerio & 18 & marceneiro & - & Rua Tenente Penna, 9 & João Valerio \\
\hline 123 & \multirow{5}{*}{$13 / 10$} & Silvio Guimarães & 24 & {$[?]$} & - & Rua Barão de Limeira, 198 & Antonio C. \\
\hline 124 & & Carlos de Castro & 21 & comerciante & - & Rua Cruzeiro, 120 & João Cavalheiro \\
\hline 125 & & Luiz Medeiros & 23 & mecânico & - & Rua Casa Verde, 22 & João G. dos Santos \\
\hline 126 & & Miguel Sartriano & 31 & marceneiro & casado & Rua Anhanguera, 13 & João Paris \\
\hline 127 & & Evaristo Monteiro & 21 & plainista & - & Rua Salta Salta, 14 & Eugenio Mazzella \\
\hline 128 & $26 / 10$ & Roque Salite & 20 & torneiro & - & Rua do Bosque, 11 & Ezzio Marchetti \\
\hline 129 & \multirow{5}{*}{$30 / 11$} & Pedro Carmella & 19 & chapeleiro & - & Av. Rudge, 32 & Ezzio Marchetti \\
\hline 130 & & Joaquim G. Santos & 23 & mecânico & - & Rua Barão de Tatuí & João Cavalheiro \\
\hline 131 & & Armando Mangi & 18 & torneiro & - & Rua Barra Tibagy, 68 & Ezzio Marchetti \\
\hline 132 & & José Marques Silva & 27 & mecânico & - & Rua Barão de Tatuí, 27 & Joaquim G. Santos \\
\hline 133 & & Bruno Taccioni & 18 & mecânico & - & Rua Solon, 52 & Ezzio Marchetti \\
\hline 134 & $21 / 12$ & Duarte de Medeiros & 23 & mecânico & - & Rua Anhanguera, 132 & Antonio Sabatini \\
\hline 135 & \multirow{5}{*}{$28 / 12$} & José Mauro & 20 & funileiro & - & Rua Cruzeiro & Antonio Sabatini \\
\hline 136 & & Mario Tunelli & 18 & barbeiro & - & Victorino Camillo, 132 & $\begin{array}{l}\text { Antonio Teixeira de } \\
\text { Carvalho }\end{array}$ \\
\hline 137 & & \begin{tabular}{|l|} 
Alvaro Teixeira de \\
Carvalho \\
\end{tabular} & 18 & pintor & - & Rua Anhanguera, 7 & $\begin{array}{l}\text { Antonio Teixeira de } \\
\text { Carvalho }\end{array}$ \\
\hline 138 & & José Alderes & 28 & pintor & - & Rua Barra Funda, 161 & Antonio Sabatini \\
\hline 139 & & Duarte Armani & 24 & operário & - & $\begin{array}{l}\text { Rua Visconde de Rio } \\
\text { Branco }\end{array}$ & - \\
\hline \multicolumn{8}{|c|}{1932} \\
\hline 1 & \multirow{4}{*}{$04 / 01$} & José Costa & 20 & comércio & - & - & Antonio Sabatini \\
\hline 2 & & Nelson Gambôa & 19 & estudante & - & - & José V. Galante \\
\hline 3 & & José Monteiro & 18 & serrador & - & - & Antonio Sabatini \\
\hline 4 & & Salvador Carbano & 19 & chapeleiro & - & - & Antonio Sabatini \\
\hline
\end{tabular}




\begin{tabular}{|c|c|c|c|c|c|c|c|}
\hline 5 & & Manoel Guerra & 19 & estudante & - & - & Antonio Sabatini \\
\hline 6 & & Luiz Ferrazoli & 36 & fundidor & - & - & Antonio Sabatini \\
\hline 7 & & Erminio Salorme & 21 & marceneiro & solteiro & - & Antonio Sabatini \\
\hline 8 & & Aldo Angelini & 18 & $\begin{array}{l}\text { empregado } \\
\text { do comércio }\end{array}$ & - & - & Oswaldo Bindo \\
\hline 9 & \multirow{17}{*}{$18 / 01$} & Antonio Miguel & 20 & mecânico & - & - & Raphael Jaen \\
\hline 10 & & Manoel Muller & 21 & $\begin{array}{l}\text { empregado } \\
\text { do comércio }\end{array}$ & - & - & Antonio Sabatini \\
\hline 11 & & João Bellis & 21 & serralheiro & - & - & Antonio Sabatini \\
\hline 12 & & Fortunato Pinechi & 21 & lapidador & - & - & Carlos Robertini \\
\hline 13 & & Orlando Navarro & 21 & $\begin{array}{l}\text { empregado } \\
\text { do comércio }\end{array}$ & - & - & Antonio Sabatini \\
\hline 14 & & João Mazini & 20 & empregado & - & - & José Valle Galante \\
\hline 15 & & Armando Aurélio & 21 & $\begin{array}{l}\text { empregado } \\
\text { do comércio }\end{array}$ & - & - & $\begin{array}{l}\text { Antonio Teixeira de } \\
\text { Carvalho }\end{array}$ \\
\hline 16 & & Pedro Mamede & 20 & $\begin{array}{l}\text { empregado } \\
\text { do comércio }\end{array}$ & - & - & $\begin{array}{l}\text { Antonio Teixeira de } \\
\text { Carvalho }\end{array}$ \\
\hline 17 & & George Ferrazoli & 24 & chauffer & - & Rua Anhanguera, 48 & Luiz Ferrazoli \\
\hline 18 & & Angelo Gaveta & - & - & - & - & $\begin{array}{l}\text { Antonio Teixeira de } \\
\text { Carvalho }\end{array}$ \\
\hline 19 & & Sapião de Mazi & - & - & - & - & Antonio Sabatini \\
\hline 20 & & Carlos Roberto & - & - & - & - & Elydio Salaone \\
\hline 21 & & José Mendes & 19 & - & - & - & $\begin{array}{l}\text { Antonio Teixeira de } \\
\text { Carvalho }\end{array}$ \\
\hline 22 & & Mario Martinelli & 20 & - & - & - & Vicente Lemont \\
\hline 23 & & Domingo Sanitló & 22 & - & - & - & $\begin{array}{l}\text { Antonio Teixeira de } \\
\text { Carvalho }\end{array}$ \\
\hline 24 & & Manoel Carvalho & 25 & - & - & - & José Medeiros \\
\hline 25 & & Waldemar Micchelloti & 19 & - & - & - & Fortunato $\mathrm{P}$. \\
\hline 26 & \multirow{4}{*}{$11 / 02$} & Jacyntho Santa & 19 & $\begin{array}{l}\text { empregado } \\
\text { do comércio }\end{array}$ & - & Rua Luzitânia, 45 & $\begin{array}{l}\text { Antonio Teixeira de } \\
\text { Carvalho }\end{array}$ \\
\hline 27 & & Orlando Pontes & 19 & fundidor & - & Rua dos Americanos, 15 & Antonio Sabatini \\
\hline 28 & & Eduardo Louzada & 24 & \begin{tabular}{|l|} 
empregado \\
do comércio
\end{tabular} & - & Rua da Mooca, 243 & Germano Bindo \\
\hline 29 & & Américo Lourenço & 20 & padeiro & - & Rua Anhanguera, 91 & Antonio Sabatini \\
\hline 30 & \multirow{3}{*}{$15 / 02$} & Francisco Lafiandra & 19 & \begin{tabular}{|l|} 
empregado \\
do comércio
\end{tabular} & - & Rua Carmo Dutra, 28 & $\mathrm{D}^{\prime}$ Amélio \\
\hline 31 & & Albino T. Carvalho & 22 & pintor & - & Rua Anhanguera, 7 & $\begin{array}{l}\text { Antonio Teixeira de } \\
\text { Carvalho }\end{array}$ \\
\hline 32 & & Francisco Gomes & 20 & $\begin{array}{l}\text { empregado } \\
\text { do comércio }\end{array}$ & - & Rua do Bosque, 229 & Antonio Sabatini \\
\hline 33 & \multirow{5}{*}{$03 / 03$} & Duilio Cordo & 21 & mecânico & - & Rua Diana, 135 & Joaquim dos Santos \\
\hline 34 & & Sylvio Ramos & 22 & \begin{tabular}{|l|} 
empregado \\
do comércio
\end{tabular} & - & $\begin{array}{l}\text { Alameda Barão de } \\
\text { Limeira, 200 }\end{array}$ & Antonio Cocito \\
\hline 35 & & Renato Capella & 19 & $\begin{array}{l}\text { empregado } \\
\text { do comércio }\end{array}$ & - & $\begin{array}{l}\text { Alameda Eduardo Prado, } \\
111\end{array}$ & Oswaldo Bindo \\
\hline 36 & & Armando Basso & 23 & \begin{tabular}{|l|} 
empregado \\
do comércio
\end{tabular} & - & $\begin{array}{l}\text { Rua Baronesa do Porto } \\
\text { Carreiro, } 24 \\
\end{array}$ & Antonio Sabatini \\
\hline 37 & & Orlando Victorino & 20 & mecânico & - & Rua Garibaldi & Angelo Catapani \\
\hline 38 & \multirow[t]{2}{*}{$09 / 03$} & Duilio Gonçalves & 23 & $\begin{array}{l}\text { empregado } \\
\text { do comércio }\end{array}$ & - & Rua Anhaia & Quinho Bernadelli \\
\hline 39 & & Antonio Vignola & 39 & marceneiro & casado & Rua Anhanguera, 92 & Matheus Sabatini \\
\hline 40 & \multirow[b]{2}{*}{$15 / 03$} & Eugenio Oliveira & 26 & chauffer & - & Barão de Rio Branco, 85 & - \\
\hline 41 & & Edson Lacerda & 18 & estudante & - & $\begin{array}{l}\text { Rua Baronesa do Porto } \\
\text { Carreiro }\end{array}$ & Germano Bindo \\
\hline
\end{tabular}




\begin{tabular}{|c|c|c|c|c|c|c|c|}
\hline 42 & \multirow{6}{*}{$29 / 03$} & T. Bruno & 18 & barbeiro & - & Rua dos Italianos, 19 & Antonio Cocito \\
\hline 43 & & Antonio Sapienza & 19 & barbeiro & - & Rua dos Italianos & Antonio Cocito \\
\hline 44 & & P. Auria & 20 & serralheiro & - & Rua Garibaldi & Antonio Cocito \\
\hline 45 & & Américo Silva & 20 & eletricista & - & Rua Barra do Tabagy, 72 & Antonio P. da Silva \\
\hline 46 & & João Morjiske & 24 & marceneiro & - & Rua Cruzeiro & Antonio Cocito \\
\hline 47 & & Antonio Basso & 22 & - & - & Rua Anhanguera, 157 & Elydio Salorne \\
\hline 48 & \multirow{3}{*}{$12 / 04$} & Amadeu Vaz & 24 & $\begin{array}{l}\text { empregado } \\
\text { do comércio }\end{array}$ & - & Rua Luzitania, 68 & Matheus Sabatini \\
\hline 49 & & Orlando Piadoreri & 19 & serralheiro & - & Rua Anhanguera, 12 & Antonio Cocito \\
\hline 50 & & Calixto Racolo & 18 & $\begin{array}{l}\text { empregado } \\
\text { do comércio } \\
\end{array}$ & - & - & Horácio Stigliano \\
\hline 51 & \multirow{5}{*}{$03 / 05$} & Vicente Carbucai & 20 & padeiro & - & Rua do Bosque, 19 & Horácio Stigliano \\
\hline 52 & & Claudino Strufaldi & 19 & $\begin{array}{l}\text { empregado } \\
\text { do comércio }\end{array}$ & - & Rua do Bosque & Angelo Catapani \\
\hline 53 & & João Russo & 20 & barbeiro & - & Rua Garibaldi, 12 & Antonio Sabatini \\
\hline 54 & & Antonio Salconi & 18 & barbeiro & - & Rua Anhanguera & Angelo Catapani \\
\hline 55 & & Palena & 20 & $\begin{array}{l}\text { empregado } \\
\text { do comércio }\end{array}$ & - & Rua Pedro Vicente & - \\
\hline 56 & \multirow{6}{*}{$10 / 03$} & Fausto Romeu & 19 & $\begin{array}{l}\text { empregado } \\
\text { do comércio }\end{array}$ & - & Rua Lopes Chavez, 61 & Afonso Lolitto \\
\hline 57 & & R. Gandolfi & 21 & escultor & - & Av. São João, 360 & Antonio Cocito \\
\hline 58 & & Bueno Rodrigues & 18 & fundidor & - & Rua dos Italianos, 179 & Antonio Cocito \\
\hline 59 & & Carmine Amuntiatelli & 20 & mecânico & - & Rua Anhaia, 23 & Antonio Cocito \\
\hline 60 & & Francisco Gomes & 21 & $\begin{array}{l}\text { empregado } \\
\text { do comércio }\end{array}$ & - & Rua do Bosque, 32 & Antonio Cocito \\
\hline 61 & & Armando Turperi & 18 & fundidor & - & Rua Tenente Penna, 47 & Antonio Cocito \\
\hline 62 & \multirow{8}{*}{$24 / 05$} & Adelino Augusto & 19 & - & - & Av. São João, 139 & Antonio Sabatini \\
\hline 63 & & Domingos A. Gregório & 32 & typhographo & - & Rua Garibaldi, 88 & Antonio Sabatini \\
\hline 64 & & Rolando Medeiros & 19 & $\begin{array}{l}\text { empregado } \\
\text { do comércio }\end{array}$ & - & Rua Anhanguera, 137 & Americo Tassarolo \\
\hline 65 & & João Pavani & 20 & graphico & - & Rua Garibaldi, 14 & Antonio Sabatini \\
\hline 66 & & Luiz Zontini & 20 & operário & - & Rua do Bosque, 161 & Raphael Jaen \\
\hline 67 & & Antonio Barroso & 23 & mecânico & - & Rua Baixa, 18 & Angelo Catapani \\
\hline 68 & & Antonio Latorre & 18 & $\begin{array}{l}\text { empregado } \\
\text { do comércio }\end{array}$ & - & Tua Tucuman, 152 & Antonio Viscardi \\
\hline 69 & & Antonio Givelli & 20 & mecânico & - & Rua do Bosque, 16 & Matheus Sabatini \\
\hline 70 & \multirow{8}{*}{$14 / 06$} & Americo Allessio & 22 & comércio & - & Rua Solon, 213 & Domingo Viasi \\
\hline 71 & & João Oliveira & 18 & comércio & - & Rua Anhaia, 213 & Antonio Cocito \\
\hline 72 & & Hugo Tagiani & 25 & marceneiro & - & Rua Barão de Tibagy, 47 & José Soares de Azevedo \\
\hline 73 & & Daniel Machieroni & 19 & graphico & - & Rua Barra do Tibagy, 9 & Libertário Rodrigues \\
\hline 74 & & Vicente Mazzini & 22 & comércio & - & Rua Boracea & Angelo Catapani \\
\hline 75 & & Cesar Rosa & 23 & operário & - & Av. Rudge & Angelo Catapani \\
\hline 76 & & João Barros & 23 & comércio & - & - & Antonio Cocito \\
\hline 77 & & João Moreira & 26 & motorista & - & Rua Luzitânia & Antonio Cocito \\
\hline 78 & \multirow{2}{*}{$28 / 06$} & Antonio Soares & 19 & mecânico & - & Rua Barão de Piracicaba & Manoel Muller \\
\hline 79 & & Antonio Veronesi & 20 & - & - & Rua Anhaia, 22 & Antonio Cocito \\
\hline 80 & & Aldo Nasi & 20 & marceneiro & - & Rua Salta Salta, 56 & Matheus Sabatini \\
\hline 81 & & Antonio Lopes & 20 & comércio & - & Rua José Paulino, 116 & Marino Paulino \\
\hline 82 & & Alcides Soares & 27 & comércio & - & Rua Brigadeiro Galvão & Ângelo Catapani \\
\hline 83 & \multirow{2}{*}{$05 / 07$} & Edson Lacerda & 18 & estudante & - & Rua Baronesa P. Carreiro, 1 & Antonio Cocito \\
\hline 84 & & Alberto Cassari & 26 & - & - & Rua Garibaldi, 60 & Germano Bindo \\
\hline
\end{tabular}




\begin{tabular}{|l|l|l|l|l|l|l|}
\hline 85 & Santi Stefano & 25 & comércio & - & Rua Cruzeiro, 123 & José Soares de Azevedo \\
\hline 86 & José Amatucci & 22 & instalador & - & Av. Rudge, 63 & Rodolpho Lima \\
\cline { 3 - 7 } 87 & Alvaro Costa & 28 & carpinteiro & - & Rua Casa Verde & Matheus Sabatini \\
\cline { 2 - 7 } & Waldemar del Aqua & 18 & serralheiro & - & Rua Garibaldi, 48 & Armando Picerni \\
\hline
\end{tabular}

Obs.: Após a Revolução Constitucionalista, o clube voltou a registrar suas assembleias em outubro de 1932, mas suas propostas foram registradas em livro novo, separadamente das atas das reuniões.

\section{3}

\begin{tabular}{|c|c|c|c|c|c|c|c|}
\hline 1 & \multirow{6}{*}{$15 / 01$} & Florindo Lovodico & 18 & - & - & Rua dos Italianos, 173 & Antonio Martins \\
\hline 2 & & Victorio Gumiero & 20 & - & - & Rua Anhanguera, 156 & Calixto Barolo \\
\hline 3 & & Pedro Benetti & 23 & - & - & Rua Cruzeiro, 89 & Victorino Gumiero \\
\hline 4 & & Radamés Avanzi & 20 & - & - & Rua Margarida, 84 & Angelo Faveta \\
\hline 5 & & Antonio F.Amaral & 24 & - & - & Rua Anhanguera & Calixto Barolo \\
\hline 6 & & Manoel M. Pereira & 25 & - & - & Rua Anhanguera & Calixto Barolo \\
\hline 7 & \multirow{4}{*}{$07 / 02$} & Moacyr Bergamini & 18 & estudante & - & Rua do Bosque, 51 & Antonio Sabatini \\
\hline 8 & & João Toscano & 26 & chapeleiro & - & Rua General Flores, 80 & Eduardo Losso \\
\hline 9 & & Casemiro Rodrigues & 26 & comércio & - & Rua Anhanguera, 97 & Antonio Cocito \\
\hline 10 & & Lourenço A. Fernandes & 18 & padeiro & - & Rua Anhanguera, 91 & José Soares de Azevedo \\
\hline 11 & \multirow{7}{*}{$14 / 02$} & Claudio Bovo & 31 & chauffer & - & Rua Anhanguera & Rodolpho Lima \\
\hline 12 & & Rui Alves & 18 & copiador & - & $\begin{array}{l}\text { Rua Baronesa do Porto } \\
\text { Carreiro, } 17\end{array}$ & - \\
\hline 13 & & Rodolpho Callarico & 22 & ferroviário & - & Rua Solon, 165 & Salvador M. Passos \\
\hline 14 & & Delpho Sapienza & 21 & comércio & - & Rua Lopes Chaves, 82 & Augusto Castanha \\
\hline 15 & & Angelo Bressiani & 22 & ferreiro & - & Rua João Rudge, 10 & Antonio Vignola \\
\hline 16 & & Antonio Oliveira & 25 & eletricista & - & Rua Anhanguera, 153 & Alberto Baptista \\
\hline 17 & & Manoel Guerra & 22 & estudante & - & Rua Cruzeiro, 120 & Antonio Cocito \\
\hline 18 & \multirow{5}{*}{$21 / 02$} & Dinovaldo Abreu & 18 & comércio & - & Rua Anhanguera, 125 & Antonio Vignola \\
\hline 19 & & José Menzani & 20 & serralheiro & - & Rua do Bosque, 61 & Rodolpho Lima \\
\hline 20 & & Manoel Costa & 24 & mechanico & - & Rua Garibaldi, 60 & Antonio Cocito \\
\hline 21 & & Antonio de Mauro & 23 & funileiro & - & Rua Barra do Tybagy, 18 & Rodolpho Lima \\
\hline 22 & & Valdomiro Pereira & 18 & comércio & - & Rua do Bosque, 75 & Antonio Cocito \\
\hline 23 & \multirow{9}{*}{$07 / 03$} & Feliciano Penatti & - & - & - & Rua Duque de Caxias, $6^{a}$ & - \\
\hline 24 & & Hameleto Masini & - & - & - & Rua Luzitânia, 48 & - \\
\hline 25 & & Victor Delloli & - & - & - & Rua do Bosque, 88 & - \\
\hline 26 & & Victor Marques & - & - & - & Rua do Bosque, 20 & - \\
\hline 27 & & Antonio Tironi & - & - & - & Rua do Bosque, 23 & Miguel Pecili \\
\hline 28 & & Francisco Pimentel & - & - & - & Rua Solon & Basali \\
\hline 29 & & Domingo Trugilo & - & - & - & Rua Luzitânia & Francisco Pimentel \\
\hline 30 & & Eduardo Louzada & - & - & - & Alameda Tabajara, 17 & P. Penatti \\
\hline 31 & & Domingo Fanganelo & - & - & - & Av. Rudge, 178 & Antonio Altieri \\
\hline 32 & \multirow{4}{*}{$13 / 03$} & Dorival Lobato & - & - & - & $\begin{array}{l}\text { Av Conselheiro Ramalho, } \\
12\end{array}$ & - \\
\hline 33 & & Moacyr Domingues & - & - & - & Av. Brigadeiro Galvão,236 & Salvador Passos \\
\hline 34 & & Carlos Cardoso & - & - & - & Rua do Bosque, 28 & Calixto Barolo \\
\hline 35 & & João Gentile & - & - & - & Rua do Bosque, 99 & Miguel Pecile \\
\hline 36 & \multirow{4}{*}{$21 / 03$} & Rolando Olivo & - & - & - & Av. Brigadeiro Galvão, 34 & Salvador Passos \\
\hline 37 & & Domingos Picerni & - & - & - & Rua do Bosque, 34 & Miguel Pecile \\
\hline 38 & & Manoel Martinez & - & - & - & Rua do Bosque, 67 & Miguel Pecile \\
\hline 39 & & Antonio Pereira & - & - & - & Rua do Bosque, 40 & Miguel Pecile \\
\hline
\end{tabular}




\begin{tabular}{|c|c|c|c|c|c|c|c|}
\hline 40 & & Agnelo Roza & - & - & - & Av. Rudge, 86 & Miguel Pecile \\
\hline 41 & & Luiz Donato & - & - & - & Rua do Bosque, 76 & Calixto Barolo \\
\hline 42 & \multirow{3}{*}{$28 / 03$} & Romeu Samados & - & - & - & Rua do Bosque, 65 & Miguel Pecile \\
\hline 43 & & Antonio Capelato & - & - & - & Rua do Bosque, 74 & Miguel Pecile \\
\hline 44 & & João Mirabele & - & - & - & Rua Anhanguera, 65 & Antonio Vignola \\
\hline 45 & \multirow{4}{*}{$04 / 04$} & Humberto Ristaldo & - & - & - & Rua Solon, 81 & Americo Olivieri \\
\hline 46 & & Mario Tagni & - & - & - & Rua Pedro Thomaz, 17 & Duilio Urruselgui \\
\hline 47 & & Antonio Bagnato & - & - & - & Rua Anhanguera, 94 & Antonio Vignola \\
\hline 48 & & Nadim Haddad & - & - & - & Rua Anhanguera, 44 & Miguel Peale[?] \\
\hline 49 & \multirow{5}{*}{$11 / 04$} & Juvenal Roque & - & - & - & Rua Tanaby, 79 & - \\
\hline 50 & & Arnaldo Giocondo & - & - & - & Rua Anhanguera, 82 & Calixto Barolo \\
\hline 51 & & Laurntino Alves & - & - & - & Rua Anhaia, 161 & Oswaldo Silva \\
\hline 52 & & Nelson Almeida & - & - & - & Rua Lopes de Oliveira, 60 & Vicente Jaen \\
\hline 53 & & Rodolpho Mitter & - & - & - & - & Antonio Vignola \\
\hline 54 & \multirow{2}{*}{$18 / 04$} & Oswaldo Bernia & - & - & - & Rua do Bosque, 59 & Miguel Pecile \\
\hline 55 & & João das Neves & - & - & - & Rua João Rudge, 13 & Miguel Pecile \\
\hline 56 & \multirow{4}{*}{$25 / 04$} & Miguel Dauria & - & - & - & Rua Garibaldi, 4 & Miguel Pecile \\
\hline 57 & & Angelo Bapartelo & - & - & - & Rua do Bosque & Miguel Pecile \\
\hline 58 & & José Loughi & - & - & - & Rua José Paulino, 204 & Miguel Pecile \\
\hline 59 & & Reinaldo Bottini & - & - & - & Rua do Bosque, 36 & Antonio Cocito \\
\hline 60 & \multirow{6}{*}{$09 / 05$} & Licieri Greco & - & - & - & Alameda Glete, 72 & Antonio Vignola \\
\hline 61 & & Angelo C. & - & - & - & Rua Anhaia, 8 & Bartholomeu Maggi \\
\hline 62 & & Figholo & - & - & - & Rua Garibaldi & Decio Zanelatto \\
\hline 63 & & Araujo & - & - & - & Rua Salta-Salta & José Cestari \\
\hline 64 & & Pontes & - & - & - & Rua dos Americanos & Antonio Cocito \\
\hline 65 & & Berner & - & - & - & Rua do Bosque & Miguel Pecile \\
\hline 66 & \multirow{2}{*}{$30 / 05$} & Mario Lolitto & - & - & - & Rua do Bosque, 67 & Calixto Barolo \\
\hline 67 & & Gracindo Leite & - & - & - & Pirituba & Manoel Muller \\
\hline 68 & \multirow{4}{*}{$06 / 06$} & Antonio de Oliveira & - & - & - & Rua Anhanguera, 153 & Paulo de Lima \\
\hline 69 & & Ítalo Anderboni & - & - & - & Rua Salta-Salta, 10 & Armando Perucini \\
\hline 70 & & Carlos Sommerfeld & - & - & - & Rua do Bosque, 41 & Calixto Barolo \\
\hline 71 & & João Meca & - & - & - & Rua Anhaia, 219 & Reynaldo Tavares \\
\hline 72 & \multirow{6}{*}{$13 / 06$} & José Batista & - & - & - & Rua Monte Alegre, 53 & Renato Monteiro \\
\hline 73 & & Manoel Menzani & - & - & - & Rua do Bosque, 61 & Saverio Russo \\
\hline 74 & & Pedro Sabri & - & - & - & Rua Anhanguera, 51 & Miguel Pecile \\
\hline 75 & & Jorge Alves Cunha & - & - & - & Rua Souza Carlos, 81 & Rodolpho Lima \\
\hline 76 & & João Victorino & - & - & - & Rua Victorino Carmillo,191 & Augusto Del'loli \\
\hline 77 & & Luis Pereira & - & - & - & Rua Homem de Mello, 110 & Miguel Pecile \\
\hline 78 & \multirow{9}{*}{$27 / 06$} & Osvaldo Bindo & - & - & - & Rua Mauá, 57 & Salvador M. Passos \\
\hline 79 & & Salvador Granieri & - & - & - & Alameda Cleveland, 71 & Americo Alessio \\
\hline 80 & & Manoel Botelho & - & - & - & Rua Helvetia, 93 & Manoel Miller \\
\hline 81 & & Manoel Carvalho & - & - & - & Largo Santa Cecília, 26 & Manoel Miller \\
\hline 82 & & Carlos Roberto & - & - & - & $\begin{array}{l}\text { Rua Visconde de Taunay, } \\
47\end{array}$ & Ezzio Bottini \\
\hline 83 & & Salvador Mazzela & - & - & - & Rua da Graça, 222 & Amadeu Mazzela \\
\hline 84 & & Francisco Borges & - & - & - & Rua Costa Silva, 64 & Rodolpho Lima \\
\hline 85 & & Mario Montanari & - & - & - & Rua Anhanguera, 144 & José Jaen \\
\hline 86 & & João Cavalheiro & - & - & - & Rua do Bosque, 86 & Manoel Miller \\
\hline
\end{tabular}




\begin{tabular}{|c|c|c|c|c|c|c|c|}
\hline 87 & & Antonio Francisco Filho & - & - & - & Rua dos Italianos, 7 & Angelo Faveta \\
\hline 88 & & Achiles Mazzini & - & - & - & Rua Carneiro Leão, 715 & Bartholomeu Maggi \\
\hline 89 & \multirow{4}{*}{$04 / 07$} & Americo Pecile & - & - & - & Rua Boracea, 38 & Calixto Barolo \\
\hline 90 & & Andre Maiolle & - & - & - & Rua Julio de Castilho, 165 & Antonio Victorino \\
\hline 91 & & Antonio Luzia & - & - & - & Rua Boracea, 36 & Miguel Pecile \\
\hline 92 & & Eugenio Mazella & - & - & - & Rua Cruzeiro, 14 & José Figliolo \\
\hline 93 & \multirow{11}{*}{$25 / 07$} & Bernardino Barone & - & - & - & Rua do Bosque, 162 & Antonio Barone \\
\hline 94 & & Jaime de Souza & - & - & - & Avenida Rudge, 18 & Salvador Carbone \\
\hline 95 & & Américo Pedro Paiva & - & - & - & Rua Anhanguera, 112 & João Penna Jr. \\
\hline 96 & & Ermelindo Capelato & - & - & - & Rua Anhanguera, 67 & Antonio Capelato \\
\hline 97 & & Marino Turini & - & - & - & Rua Barra do Tibagy, 109 & Antonio Francisco \\
\hline 98 & & Luiz Gasperazzo & - & - & - & Rua do Bosque, 95 & Carmino Nunciatelli \\
\hline 99 & & Joaquim Baptista & - & - & - & Rua Cruzeiro, 99 & Miguel Pecile \\
\hline 100 & & Vicente Mazzini & - & - & - & Rua Boracea, 38 & Antonio Cocito \\
\hline 101 & & Victor Curdo & - & - & - & Rua Canindé, 71 & Salvador M. Passos \\
\hline 102 & & José Moreira dos Santos & - & - & - & $\begin{array}{l}\text { Rua Cardoso de Almeida, } \\
26\end{array}$ & Raphael Jaen \\
\hline 103 & & Decio Cunha Castro & - & - & - & Rua Julio Conceição, 25 & Miguel Pecile \\
\hline 104 & \multirow{4}{*}{$01 / 08$} & Plinio Cotture & - & - & - & Rua Teodoro Sampaio, 84 & Antonio Altieri \\
\hline 105 & & Carlos Sayar & - & - & - & Rua do Cruzeiro, 158 & Antonio Vignola \\
\hline 106 & & Mario d’Ângelo & - & - & - & Rua Anhaia, 243 & Luiz Donato \\
\hline 107 & & Mauro Prado & - & - & - & Rua João Theodoro, 214 & Romeu Somadossi \\
\hline 108 & \multirow{9}{*}{$22 / 08$} & Avelino Wesh & - & - & - & Rua do Bosque, 29 & Calixto Barolo \\
\hline 109 & & João de Oliveira & - & - & - & Rua Anhanguera, 153 & Paulo de Lima \\
\hline 110 & & José Granieri & - & - & - & Rua Dino Bueno, 45 & Julio Granieri \\
\hline 111 & & João Tessitoro & - & - & - & Rua Garibaldi, 88 & Benedito Caccavo \\
\hline 112 & & Mario Cardoso & - & - & - & Rua Garibaldi, 66A & Benedito Caccavo \\
\hline 113 & & Manoel Corrêa & - & - & - & Rua Anhanguera, 1 & Miguel Pecile \\
\hline 114 & & João Felitte & - & - & - & Rua Solon, 81 & João Mecca \\
\hline 115 & & Henrique Searles & - & - & - & Rua Anhaia, 193 & Antonio Vignola \\
\hline 116 & & Antonio de Oliveira & - & - & - & Rua Anhanguera, 153 & Paulo de Lima \\
\hline 117 & \multirow{4}{*}{$19 / 09$} & Francisco Stabile & - & - & - & Rua João Passalacena, 26 & Antonio C. Carvalho \\
\hline 118 & & Rubens Aguiar & - & - & - & Rua Minerva, 1 & Plinio Coturre \\
\hline 119 & & Arlindo Aguiar & - & - & - & Rua Minerva, 1 & Plinio Coturre \\
\hline 120 & & Guido Gori & - & - & - & Rua Minerva, 90 & Antonio Cassari \\
\hline 121 & \multirow{3}{*}{$03 / 10$} & Carmo Haddad & - & - & - & - & - \\
\hline 122 & & Brasílio João Chieregatti & - & - & - & - & - \\
\hline 123 & & Hugo Genari & - & - & - & - & - \\
\hline 124 & \multirow{3}{*}{$17 / 10$} & Antonio da Graça & - & - & - & Rua Garibaldi, 68 & Decio Zanelatto \\
\hline 125 & & Scipião Lemante & - & - & - & Rua Cruzeiro, 102 & Joaquim Batispta \\
\hline 126 & & Jose Monteiro & - & - & - & Rua Salta-Salta, 14 & José Jaen \\
\hline 127 & \multirow{2}{*}{$26 / 10$} & \begin{tabular}{|l|} 
José Donato \\
\end{tabular} & - & - & - & Rua do Bosque, 76 & Miguel Pecile \\
\hline 128 & & Guerino Salaorni & - & - & - & Rua Anhanguera, 167 & Octavio Salaorni \\
\hline 129 & \multirow{5}{*}{$14 / 11$} & José Cardeal & - & - & - & Rua do Bosque, 62 & Miguel Pecile \\
\hline 130 & & Isidoro Menegão & - & - & - & Rua Javahés,99 & Antonio Cocito \\
\hline 131 & & José Bucci & - & - & - & Rua Areial, 58 & Antonio Cocito \\
\hline 132 & & Paulo Borelli & - & - & - & Rua Areial, 58 & Antonio Cocito \\
\hline 133 & & José Ceretti & - & - & - & Rua Javahés, 10 & Victorio Olivieri \\
\hline
\end{tabular}




\begin{tabular}{|c|c|c|c|c|c|c|c|}
\hline 134 & & Waldemar Bertocci & - & - & - & Rua Cruzeiro, 110 & Miguel Pecile \\
\hline 135 & & Salvador Cantagalo & - & - & - & Rua Anhanguera, 71 & Miguel Pecile \\
\hline 136 & & Diniz Couto & - & - & - & Rua Barra Funda, 96 & Antonio Althieri \\
\hline 137 & \multirow{3}{*}{$21 / 11$} & Olivio Brazzati & - & - & - & Rua Elias Chaves, 2 & Salvador Cantagalo \\
\hline 138 & & Ferdinando Fuzer & - & - & - & $\begin{array}{l}\text { Rua Baronesa Porto } \\
\text { Carreiro, } 18\end{array}$ & Antonio Vignola \\
\hline 139 & & José Carito & - & - & - & Rua Salta-Salta, 36 & Nadim Haddad \\
\hline 140 & \multirow{3}{*}{$28 / 11$} & José Amatucci & - & - & - & Av. Rudge, 63 & José Corelli \\
\hline 141 & & José Pereira & - & - & - & Rua dos Italianos & José Cestari \\
\hline 142 & & José Rema & - & - & - & Rua Garibaldi & José Figliolo \\
\hline 143 & \multirow{4}{*}{$05 / 12$} & Augusto de Felice & - & - & - & Rua Baronesa P. Carreiro, 2 & Miguel Pecile \\
\hline 144 & & Armando Silva & - & - & - & Rua Garibaldi, 76 & José Rema \\
\hline 145 & & Altino Pacheco & - & - & - & Rua Garibaldi, 76 & Orlando Pontes \\
\hline 145 & & Paulo Viscardi & - & - & - & Rua Javahés, 36 & Miguel Pecile \\
\hline 146 & \multirow{3}{*}{$12 / 12$} & Nestor Ferro & - & - & - & Rua Anhanguera, 96 & Antonio M. \\
\hline 147 & & José Adão & - & - & - & Rua Cruzeiro, 133 & Miguel Pecile \\
\hline 148 & & Joaquim da Costa & - & - & - & - & Joaquim J. dos Santos \\
\hline 149 & $19 / 12$ & Antonio Mazzella & - & - & - & Rua do Bosque, 103 & Miguel Pecile \\
\hline 150 & \multirow{4}{*}{$27 / 12$} & Alberto Preto & - & - & - & Al. Rio Branco, 181 & Miguel Pecile \\
\hline 151 & & Alberto Esquetini & - & - & - & Rua Jaraguá, 168 & Noemio Martins \\
\hline 152 & & José Pacheco & - & - & - & Rua do Bosque, 6 & José Valle Galante \\
\hline 153 & & Alfredo Gonçalvez & - & - & - & Rua Anhanguera, 125 & Antonio M. \\
\hline \multicolumn{8}{|c|}{1934} \\
\hline 1 & \multirow{4}{*}{$05 / 01$} & José Navarro & 21 & - & solteiro & \begin{tabular}{|l|} 
Rua Dr. Virgílio do \\
Nascimento \\
\end{tabular} & André Maiolle \\
\hline 2 & & Dario Bueno & 22 & - & - & Av. Rudge, 66 & Roberto S. \\
\hline 3 & & Orlando de Oliveira & 20 & - & - & Rua Anhanguera, 153 & Ferdinando Fuzer \\
\hline 4 & & Enio Anderbone & 21 & - & - & Rua Salta-Salta & Miguel Pecile \\
\hline 5 & \multirow{4}{*}{ 08/01 } & Geraldo S. & 21 & - & - & Rua Luzitânia, 31 & Miguel Pecile \\
\hline 6 & & Juvenal P. & 24 & - & - & Rua Itaporama, 32 & Angelo Catapani \\
\hline 7 & & Antonio Domingues & 20 & - & - & Rua Anhanguera, 90 & Angelo Catapani \\
\hline 8 & & Eduardo Sanchez & 26 & - & - & Rua Sólon, 55 & Angelo Catapani \\
\hline 9 & \multirow{3}{*}{$14 / 01$} & Luiz Marques & 19 & - & - & Rua do Bosque, 88 & Vitor Marques \\
\hline 10 & & José M. & 20 & - & - & Rua Anhanguera, 106 & Orlando de Oliveira \\
\hline 11 & & Antonio Viscardi & 21 & - & - & Rua Javahés, 30 & Angelo Catapani \\
\hline 12 & \multirow{5}{*}{$23 / 01$} & Romeu Pini & 21 & - & - & Av Rudge, 10 & Angelo Catapani \\
\hline 13 & & Domingos Bonamo & - & - & - & Rua Garibaldi, 8 & Renato Monteiro \\
\hline 14 & & Alexandre Montovani & - & - & - & Rua Tocantins, 44 & José Cestari \\
\hline 15 & & Eduardo Valentim & - & - & - & Rua Pedro Thomaz, 7 & José Cestari \\
\hline 16 & & Armando Ambra & - & - & - & Rua do Bosque, 40 & Miguel Barbosa \\
\hline 17 & \multirow{2}{*}{$29 / 01$} & Antonio Ferreira & - & - & - & Av. Rudge, 120 & Angelo Catapani \\
\hline 18 & & Eduardo Louzada & - & - & - & Indianópolis & Angelo Catapani \\
\hline 19 & \multirow{4}{*}{$26 / 02$} & Adriano Veronesi & 30 & - & - & Rua Dr. Costa Silva, 32 & Miguel Barbosa \\
\hline 20 & & José Pucci & 19 & - & - & Rua Anhanguera, 56 & Calixto Barolo \\
\hline 21 & & Emilio Mutarore & 19 & - & - & Rua Anhaia, 64 & Duilio Uruselqui \\
\hline 22 & & Romeu B. & 22 & - & - & Al. Ribeiro da Silva, 6 & Angelo Catapani \\
\hline 23 & \multirow{2}{*}{$05 / 03$} & Francisco Portella & 20 & - & - & Rua Cruzeiro, 19 & Joaquim Penna Jr. \\
\hline 24 & & Osvaldo A. de Oliveira & 19 & - & - & Rua Anhanguera, 147 & Orlando de Oliveira \\
\hline
\end{tabular}




\begin{tabular}{|c|c|c|c|c|c|c|c|}
\hline 25 & \multirow{10}{*}{$17 / 04$} & Armenio dos S. Ferreira & - & - & - & Rua Javahés, 56 & Antonio T. de Carvalho \\
\hline 26 & & Francisco Castino & - & - & - & Rua da Consolação, 42 & Calixto Barolo \\
\hline 27 & & Pedro Trindade & - & - & - & Rua Costa e Silva, 60 & Augusto Castanha \\
\hline 28 & & Antonio S. & - & - & - & Rua do Bosque, 49 & Miguel Barbosa \\
\hline 29 & & Francisco Navarro & - & - & - & Rua Luzitânia, 80A & Miguel Barbosa \\
\hline 30 & & João Barbosa & - & - & - & Rua Barra Funda, 255 & Miguel Barbosa \\
\hline 31 & & Orlando Câmara & - & - & - & Rua Dino Bueno, 96 & Angelo Catapani \\
\hline 32 & & José Soares & - & - & - & Rua Garibaldi, 36 & Miguel Barbosa \\
\hline 33 & & Oscar Muniz & - & - & - & Rua Baixa, 22 & Calixto Barolo \\
\hline 34 & & Antonio M. & - & - & - & Rua Oriente, 24 & João Mirabelli \\
\hline 35 & \multirow{6}{*}{$15 / 05$} & Sabatini Velardo & - & - & - & Rua Florêncio de Abreu, 45 & Antonio Cocito \\
\hline 36 & & Adolpho Lescher & - & - & - & Rua dos Americanos, 48 & Miguel Pecile \\
\hline 37 & & Orlando Zucarelli & - & - & - & Rua Tentene Pena, 76 & Nadim Haddad \\
\hline 38 & & Roberto Zucarelli & - & - & - & Rua Tentene Pena, 76 & Calixto Barolo \\
\hline 39 & & Paschoal de Oliveira & - & - & - & Rua Anhanguera, 159 & Ermelindo Capellato \\
\hline 40 & & Alberto Tavares & - & - & - & Rua Baixa, 10 & Reynaldo Tavares \\
\hline 41 & \multirow{4}{*}{$21 / 05$} & Messias Abranches & - & - & - & Rua Garibaldi, 58 & Jorge Roatta \\
\hline 42 & & Dr. Torres Neto & - & - & - & Rua Anhanguera, 2 & Jorge Roatta \\
\hline 43 & & Dr. Lázaro de Almeida & - & - & - & Rua Anhanguera, 2 & Jorge Roatta \\
\hline 44 & & Francisco de Almeida & - & - & - & Rua Anhanguera, 2 & Jorge Roatta \\
\hline 45 & \multirow[b]{2}{*}{$11 / 06$} & Angelino Rosa & - & - & - & Av. Rudge, 136 & Miguel Barbosa \\
\hline 46 & & Benedito. F. de Andrade & - & - & - & \begin{tabular}{|l} 
Rua Comandante Salgado, \\
67
\end{tabular} & Vitor Marques \\
\hline 47 & \multirow{2}{*}{$25 / 06$} & Oswaldo Tirone & - & - & - & Rua do Bosque, 23 & Miguel Barbosa \\
\hline 48 & & Marcelino Camargo & - & - & - & Rua Javahés, 62 & João Penna Jr. \\
\hline 49 & $02 / 07$ & Silvestre Cardoso & - & - & - & Rua Garibaldi, 18 & Orlando Pontes \\
\hline 50 & $16 / 07$ & Antonio Arena & - & - & - & Rua Barra do Tibagy, 124 & Angelo Catapani \\
\hline 51 & $23 / 07$ & Alcides C. & - & - & - & Rua Jaraguá, 142 & João M. \\
\hline 52 & \multirow{2}{*}{$30 / 07$} & Henrique Hilst & - & - & - & Rua João Rudge, 28 & João M. \\
\hline 53 & & Laudelino Bicudo & - & - & - & Rua Paula Nery, 77 & Alcides Caniatto \\
\hline 54 & \multirow{6}{*}{$13 / 08$} & Orlando Crepaldi & - & - & - & Rua do Bosque, 18 & Paulo Viscardi \\
\hline 55 & & Luiz T. & - & - & - & Rua dos Italianos, 64 & Antonio Tironi \\
\hline 56 & & José Guarnieri & - & - & - & Rua Adolpho Gordo, 44 & Geraldo Marasco \\
\hline 57 & & Renato Bevilacqua & - & - & - & Pça Olavo Bilac & Geraldo Marasco \\
\hline 58 & & \begin{tabular}{|l|} 
João Figueira \\
\end{tabular} & - & - & - & Rua Victorino Camillo, 169 & Miguel Pecile \\
\hline 59 & & Custódio Paulo & - & - & - & Rua das Palmeiras, 47 & Nadim Haddad \\
\hline 60 & \multirow{4}{*}{$27 / 08$} & Ignácio Gentil & - & - & - & Rua do Bosque, 99 & Armando da Silva \\
\hline 61 & & Rubens Nóbrega & - & - & - & Rua Itapirucu, & Nadim Haddad \\
\hline 62 & & Carlos Paes & - & - & - & Rua Sta Ephigenia, 97 & João M. \\
\hline 63 & & Angelo Casertelli & - & - & - & Rua do Bosque, 232 & José Donato \\
\hline 64 & \multirow{5}{*}{$24 / 09$} & Francisco Zenicolo & 22 & polidor & solteiro & Rua João Rudge, 9 & Decio Zanelatto \\
\hline 65 & & \begin{tabular}{|l|} 
Antonio Capelli \\
\end{tabular} & 19 & fundidor & solteiro & Rua Luzitânia, 30 & João Mirabelli \\
\hline 66 & & Mario Cataau & 22 & contador & solteiro & $\begin{array}{l}\text { Rua Baronesa Porto } \\
\text { Carreiro, } 25\end{array}$ & Domingos Fanganello \\
\hline 67 & & José Ramos & 18 & comércio & solteiro & Rua Anhanguera, 63 & José Donato \\
\hline 68 & & Mario Felice & 18 & mecânico & solteiro & $\begin{array}{l}\text { Rua Baronesa Porto } \\
\text { Carreiro, } 2\end{array}$ & Orlando Oliveira \\
\hline
\end{tabular}




\begin{tabular}{|c|c|c|c|c|c|c|c|}
\hline 69 & \multirow{12}{*}{$22 / 10$} & Arnaldo Tirone & - & - & - & Rua do Bosque & Oswaldo Tirone \\
\hline 70 & & Roberto Berner & - & - & - & Rua Costa e Silva, 100 & João Maggi \\
\hline 71 & & João Gomes & - & - & - & Rua João Theodoro, 128 & João Maggi \\
\hline 72 & & Orlando Rodrigues & - & - & - & Rua Anhanguera, 43 & Nestor Ferro \\
\hline 73 & & Alberto del'Aqua & - & - & - & Rua Salta-Salta, 8 & Calixto Barolo \\
\hline 74 & & Antonio Fonseca & - & - & - & Rua Anhaia, 155 & Calixto Barolo \\
\hline 75 & & Nello Adriani & - & - & - & Rua do Bosque, 37 & Calixto Barolo \\
\hline 76 & & Oreste Castaldelli & - & - & - & Rua do Bosque, 37 & Calixto Barolo \\
\hline 77 & & Eugenio de Oliveira & - & - & - & Rua Garibaldi, 43 & Nadim Haddad \\
\hline 78 & & Alfredo Onofre & - & - & - & Rua Norton Prado, 158 & Antonio M. \\
\hline 79 & & Antonio Bagnato & - & - & - & Rua Anhanguera, 94 & João M. \\
\hline 80 & & Armando Teixeira & - & - & - & Rua Anhaia, 94 & João Mirabelli \\
\hline
\end{tabular}


ANEXO B

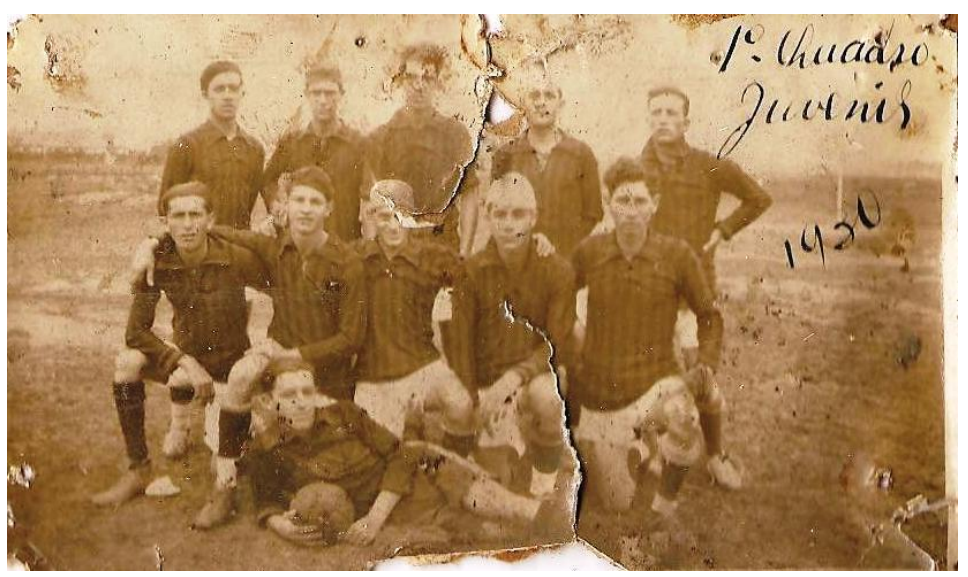

Figura 21 - Time principal juvenil, 1930. (Fonte: Acervo do clube)

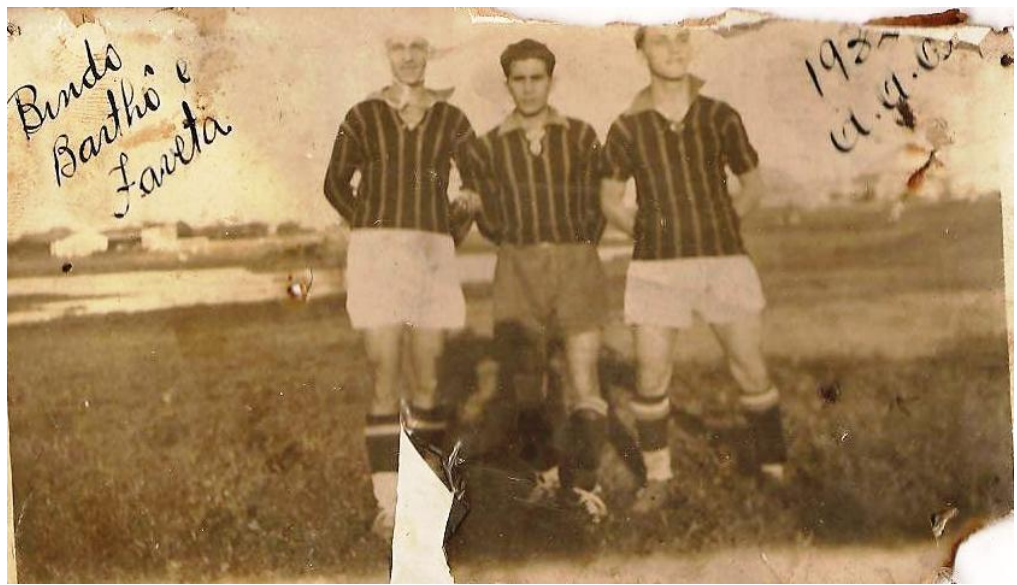

Figura 22 - Germano Bindo, Bartholomeu Maggi e João Faveta, 1932. (Fonte: Acervo do clube)

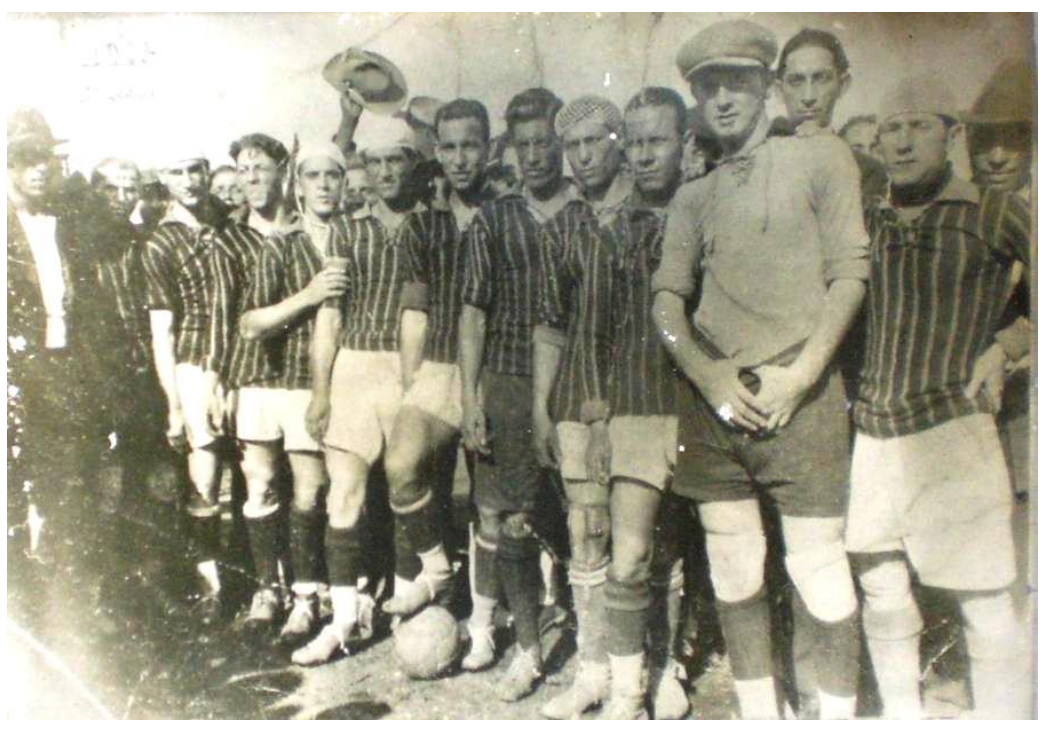

Figura 23 - Time de futebol Anhanguera (Saverio Russo ao centro com a bola), 1933. (Fonte: Acervo do clube) 

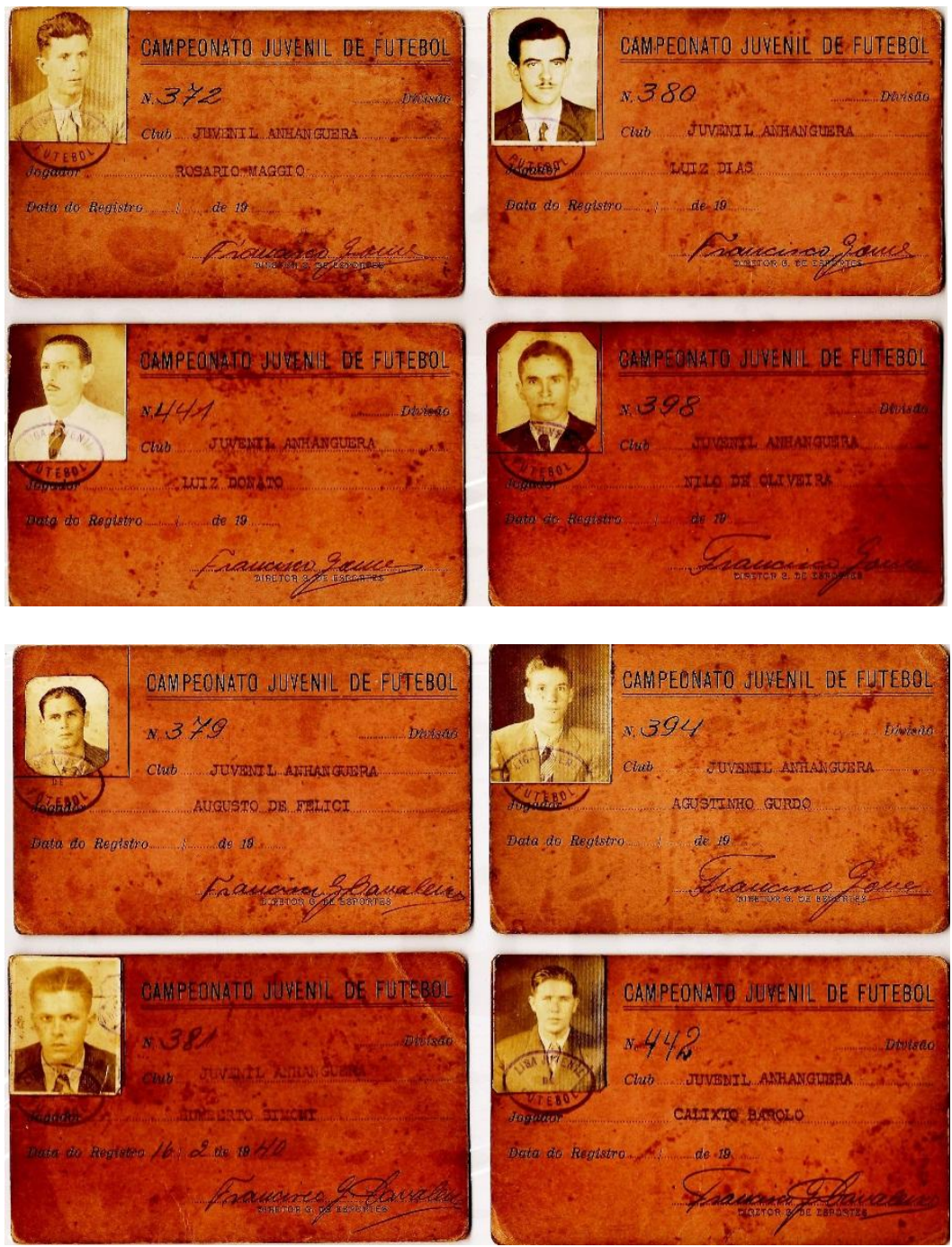

Figura 24 - Carteiras de novos associados, s.d. (entre 1930 e 1934). (Fonte: Acervo do clube)

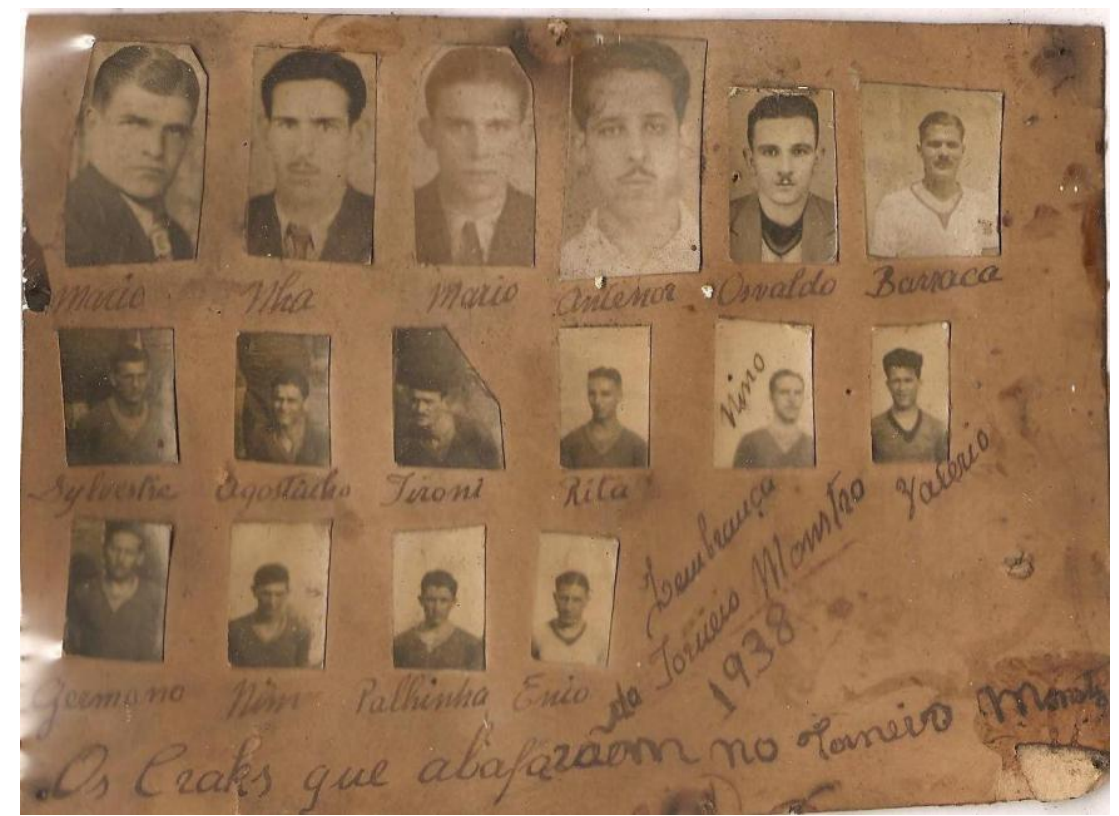

Figura 25 - Painel com o time principal da Associação Atlética Anhanguera, 1938. (Fonte: Acervo do clube) 


\section{Mapa 1}

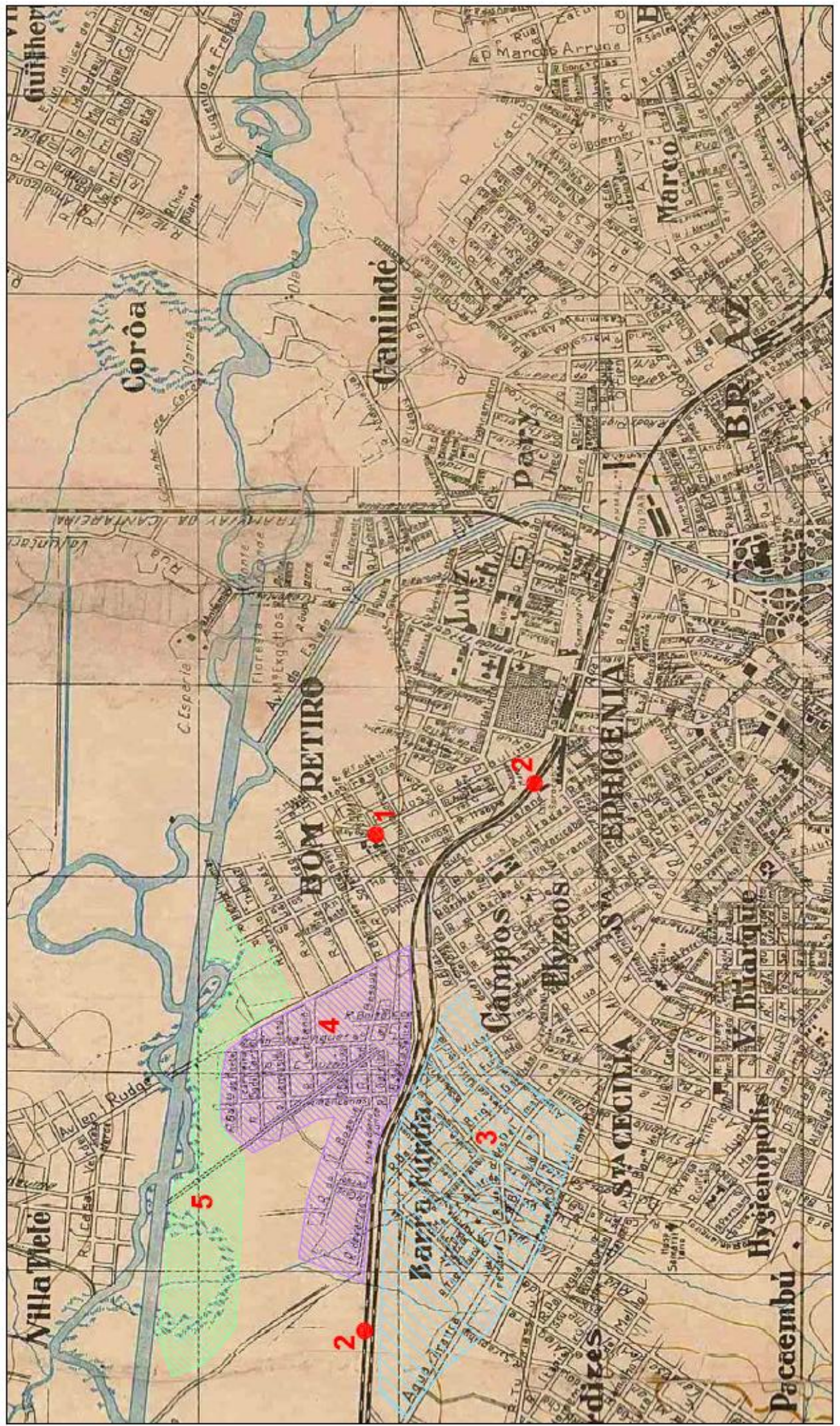

1. Hospedaria dos Imigrantes

2. Ferrovia Sorocabana

3. Barra Funda de cima

4. Barra Funda de baixo

5. Região de chácaras de vacarias 


\section{Mapa 2}

1. Rua do Córrego

2. Rua Anhanguera X Rua do Bosque

3. Rua Anhanguera $x$ Porteiras da Ferrovia Sorocabana

4. Rua dos Americanos
5. Rua Visconde de Taunay

6. Avenida Rudge

7. Rua Lopes de Oliveira

8. Desinfectório do Bom Retiro

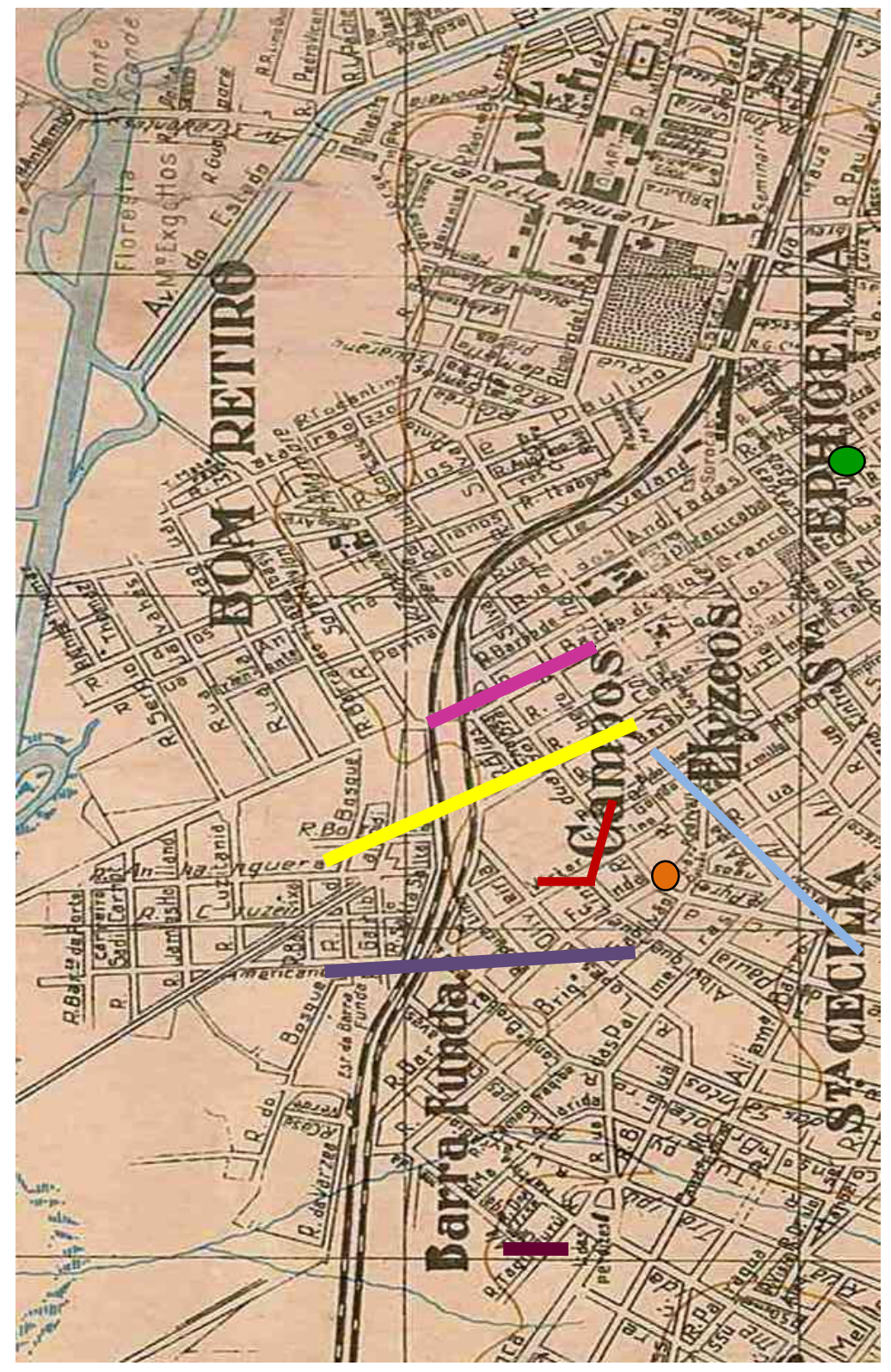


Planta da cidade de São Paulo mostrando todos os arrebaldes e terrenos arruados, 1924 
Mapa de Expansão da Área urbanizada da Região Metropolitana de São Paulo, 1930/1949. 